


\section{IMAGINAR: DIBUJAR Y ESCRIBIR RECORRIDOS PEDAGÓGICOS ALREDEDOR DEL PROYECTAR JUNTO A JAVIER SEGUÍ}



A mi padre por lo que ha sido. A mi madre por lo que sigue siendo. 
ÍNDICE 
RESUMEN

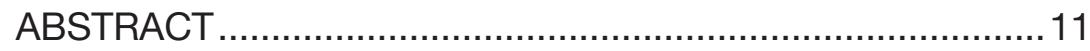

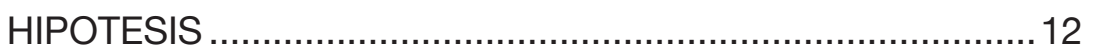

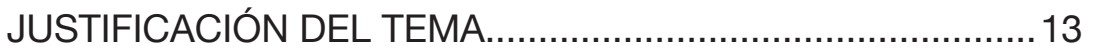

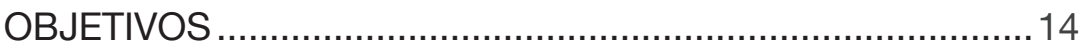

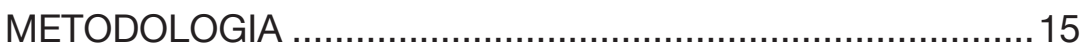

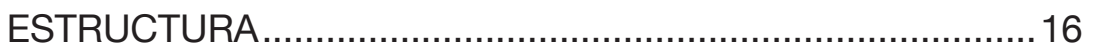

ESTADO DE LA CUESTIÓN......................................................

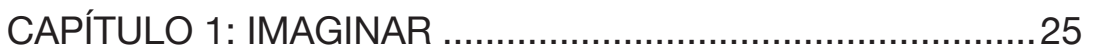

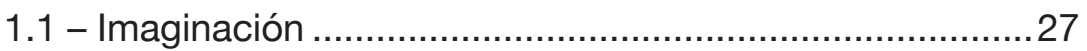

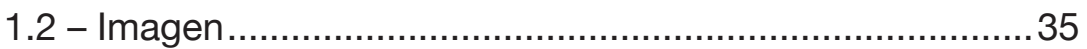

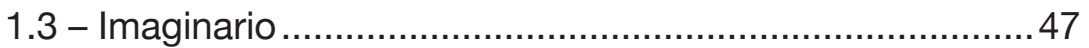

1.4 - El imaginario de Javier Seguí .......................................59

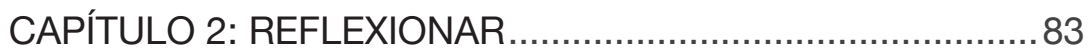

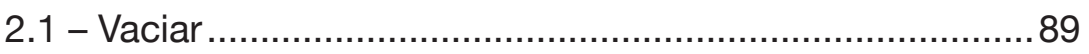

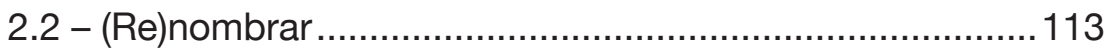

2.3 - Llegar al grado cero......................................................123

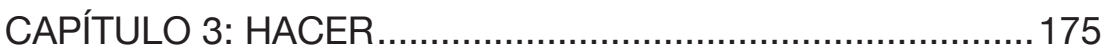

3.1 - Proyectar, Dibujar, Escribir ........................................179

3.1.1 - Proyectar ................................................... 188

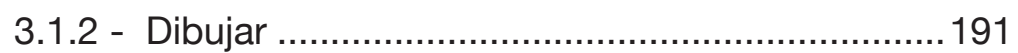

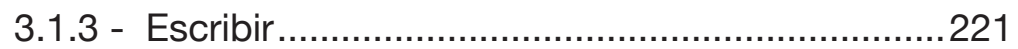

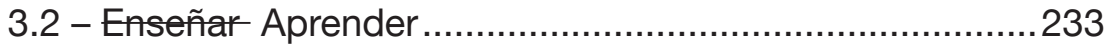

3.2.1 - Seguí en la E.T.S.A.M......................................246

3.2.2 - Javier Seguí: profesor .......................................250

3.2.3 - Ciudades radicales........................................... 330

3.3 - Técnicas operativo-imaginarias.......................................385

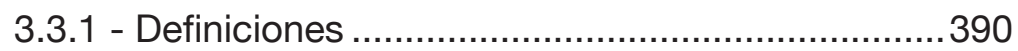

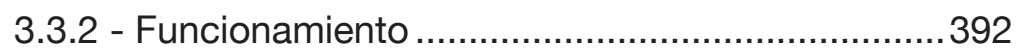

3.3.3 - Descripción y clasificación ..................................394

3.3.4 - Diagramar, e-moción, extrañamiento .................. 427

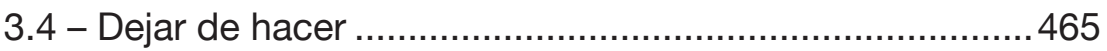

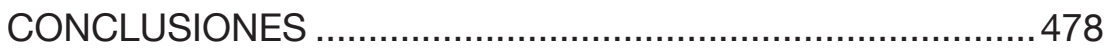

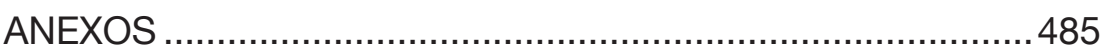

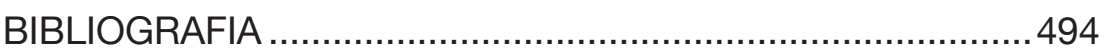


Es una buena costumbre si alguien, aparte del ponente, os ha ayudado con consejos orales, préstamo de libros raros o ayudas de otro tipo, insertar al principio o al final de la tesis una nota de agradecimiento. Sirve también para mostrar que os habéis preocupado de consultar a gente de aquí y de allá. Es de mal gusto dar las gracias al ponente. Si os ha ayudado no ha hecho más que cumplir con su obligación. ${ }^{1}$

A mi familia, viva o no, que es la resonancia de mi alma y siempre va a estar ahí.

A mis amigos, los que quedan y los que no pudieron suportarlo, que son la renovación necesaria a la dura cotianiedad.

A mi equipo de bravos alentadores del Cafelito y del Mercado de San Fernando, que han sido, por mucho tiempo, los oídos generosos de mis desasosiegos.

Al equipo académico que acompañó mi estancia en la Faculdade de Arquitectura da Universidade do Porto y que aportó un importante avance cognitivo en la temática que aquí presentamos: Profesores Doctores Rui Braz Afonso, Luis Soares Carneiro y Helder Casal Ribeiro.

A Javier Seguí por su generosidad al dejarse descubrir y por compartir conmigo su pasión por la enseñanza, sus sonrisas y zumos de naranja matinales
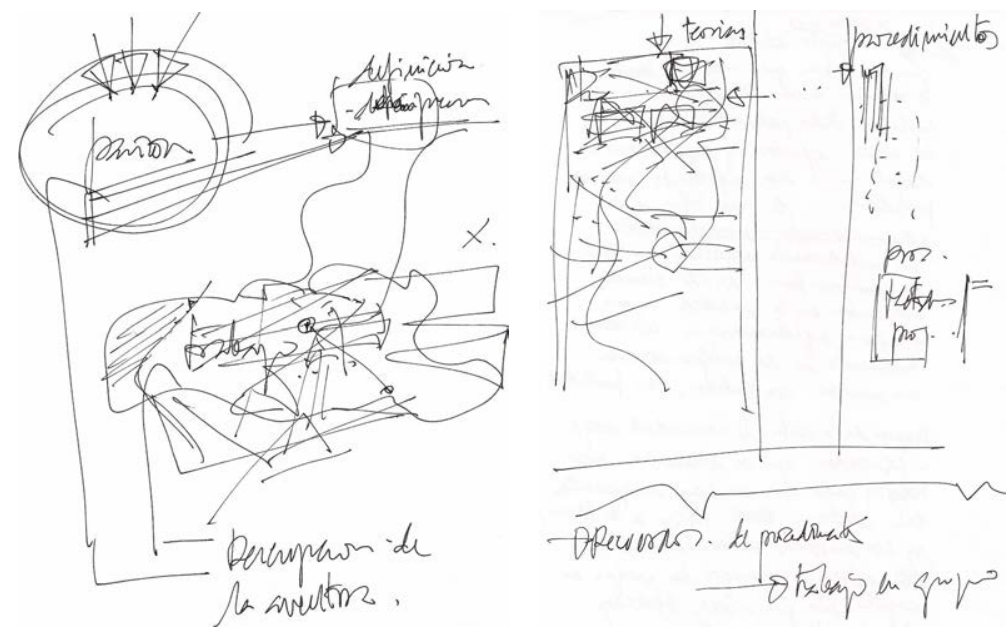

CROQUIS, (2012). Javier Seguí. Esquemas estructurales de cómo abordar la tesis doctoral.

\footnotetext{
${ }^{1}$ Umberto Eco, Como Se Faz Uma Tese Em Ciências Humanas, trad. Ana Falcão y Luis Leitão (Lisboa: Editorial Presença, 2007), 197-198.
} 
Mi agradecimiento eterno a mi directora, ya amiga y parte de la familia Atxu Amann Alcocer.
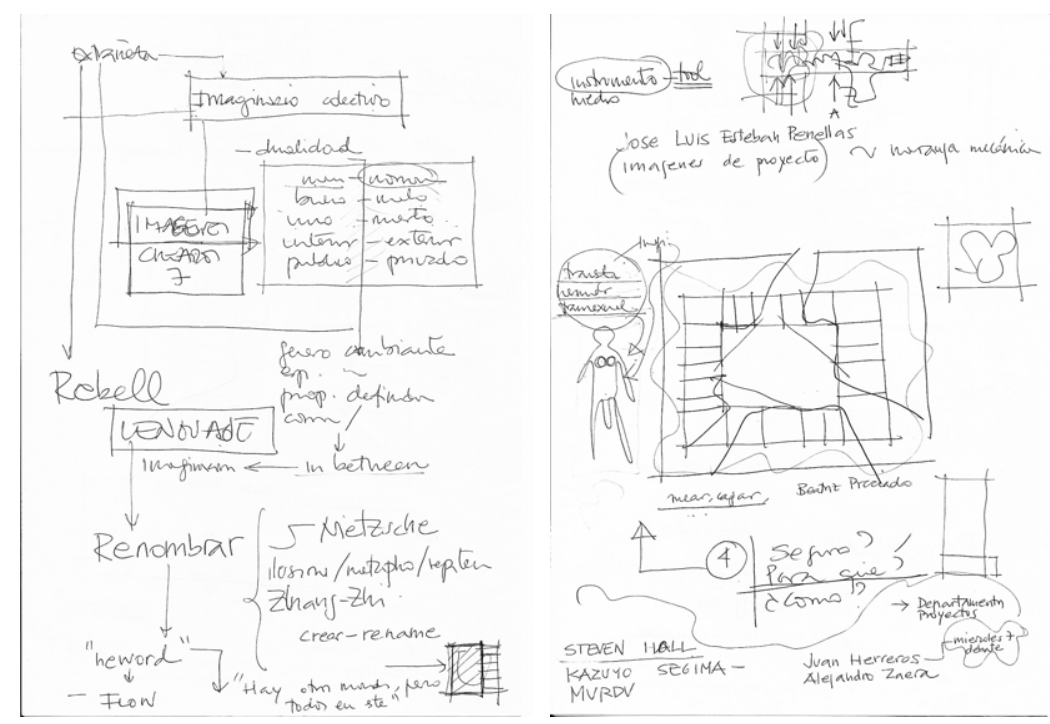

CROQUIS, (2012). Atxu Amann. Esquemas estructurales de cómo abordar la tesis doctoral. 


\section{RESUMEN}

En la enseñanza de la arquitectura, el dibujo es tradicionalmente una materia propedéutica que requiere años de entrenamiento hasta conseguir la destreza necesaria para convertirse en herramienta de configuración y en lenguaje de comunicación del proyecto.

El requerimiento de un dominio del dibujo eminentemente instrumental es el que encuentra en el año 1957 Javier Seguí, cuando entra en la Escuela Técnica Superior de Arquitectura de Madrid, y también en 1974, al obtener la cátedra de la asignatura de Análisis de Formas Arquitectónicas tras intentar, sin éxito, la cátedra de la asignatura Proyectos Arquitectónicos.

Desde entonces, y durante treinta y nueve años como catedrático, ejerce de profesor en el ahora denominado Departamento de Ideación Gráfica Arquitectónica -agrupamiento de asignaturas encuadradas en un área de conocimiento- trabajando junto a un grupo de compañeros y alumnos que intentan desarrollar un proceso de cambio fundamental en la docencia del dibujo para abandonar la pura representación y convertirla en el dibujar para proyectar.

Javier Seguí se jubila en el año 2010. Separado de la docencia y la investigación oficial, continúa dibujando y escribiendo, con el objeto de sistematizar y fundamentar todas aquellas prácticas desarrolladas y reivindicar el funcionamiento de la imaginación. Esta actividad de investigación, desde un extrañamiento extremo, permite elaborar tanto un listado de técnicas operativo-imaginarias de arranque de los procesos de proyectar, como reflexionar y recuperar algunas prácticas desarrolladas desde el grado cero y la radicalidad.

Esta investigación aborda la práctica docente de Javier Seguí, ligándola a su producción investigadora desde sus propios dibujos, escritos y conversaciones realizadas en un momento en el que la crisis de la asignatura de dibujo es evidente en un contexto universitario desorientado, que constata el fracaso del cambio que Seguí soñara hace medio siglo. 


\section{ABSTRACT}

In the teaching of architecture, drawing has traditionally been a propaedeutic subject requiring years of training to achieve the necessary skill to become a language and communication tool for project configuration.

The requirement of a drawing domain aseminently instrumental is what Javier Seguí found in 1957 when he entered the Superior Technical School of Architecture of Madrid (Escuela Técnica Superior de Arquitectura de Madrid), and also in 1974, when he was awarded the position of Chair of Analysis of Architectural Forms after trying, unsuccessfully, the Chair of Architectural Projects.

Since then, and for thirty-nine years as a Professor, he has taught at what now is called the Department of Architectural Graphic Ideation - group of subjects framed as an knowledge area -, in collaboration with a group of colleagues and students who try to develop a process of fundamental change in the teaching of drawing, through the abandonment of pure representation to transform drawing into a project.

Javier Seguí retired in 2010. Separated from official teaching and research, he maintains a consistent practice of drawing and writing, in order to systematize and substantiate all practices developed and claim the use of the imagination. This research activity, from a one end distance, allows both a list of imaginary operational techniques to the start-up project processes, as much as recovering some practices developed from scratch and of a radical technical degree.

This research addresses the teaching practice of Javier Segui, linking its research output of their own drawings, writings and conversations in a moment in which the crisis of the drawing subject is evident in a disoriented university context, demonstrating the failure of the exchange that Seguí has dreamed of since half a century ago. 


\section{HIPÓTESIS DE LA TESIS}

La hipótesis de esta tesis enuncia que la actividad desarrollada por el arquitecto Javier Seguí de la Riva durante el período de 1975 a 2010 en la Escuela Técnica Superior de Arquitectura de Madrid como profesor e investigador siendo catedrático de la asignatura Análisis de Formas Arquitectónicas en el Departamento de Ideación Grafica Arquitectónica y liderando un colectivo de profesores, arquitectos y artistas con quienes comparte un imaginario. Este análisis es fundamental para entender los cambios que se operan en el aprendizaje del dibujar arquitectónico a finales del siglo XX.

Consecuentemente, se puede derivar otra hipótesis que expresa que la sustitución del dibujar tradicional representativo -separado del proceso de proyectar - por un dibujar de la configuración y de la comunicación arquitectónica, resulta imprescindible para enfrentarse a las transformaciones que el siglo XXI introduce en la propia práctica profesional, tanto en aspectos instrumentales como conceptuales, anticipando nuevos campos emergentes en el aprendizaje y en los modos de operar en arquitectura.

Asimismo, a la vista del análisis de la situación actual en la Escuela Técnica Superior de Arquitectura de Madrid, y tras la lectura atenta y evolutiva de las intervenciones de los congresos de Expresión Gráfica Arquitectónica (EGA), se intuye que los aspectos relacionados, comunicativos o ligados a la propia estructura de la Universidad han impedido que dichos cambios continúen y se asuman por la gran mayoría de los docentes e investigadores implicados. Al contrario, parecen haber favorecido, en la mayoría de los casos, un retroceso intelectual y una nueva separación entre el dibujo y el resto de la práctica arquitectónica. 


\section{JUSTIFICACIÓN DEL TEMA}

En estos tiempos de crisis y cambios aparentemente definitivos desde Bolonia, cuando la profesión de arquitecto evidencia su necesidad de reinventarse y justificarse ante una sociedad a la que ha dado la espalda, esta investigación sabe leer la oportunidad espacio-temporal de coincidir con el arquitecto Javier Seguí de la Riva durante el periodo 2010-2015 y analizar su figura, para descubrir los cambios producidos en otros tiempos donde también hubo que plantear alternativas al estado de la cuestión en el aprendizaje del dibujar dentro de esta carrera profesional.

Gracias a que Javier Seguí de la Riva es todavía un intelectual vivo y en activo que comparte sus reflexiones con los alumnos de posgrado, este trabajo puede nutrirse de fuentes primarias y directas que comparte con las voces de todos aquellos que escriben sobre el profesor o en relación a los temas que aquí se abordan.

Sus cuantiosas reflexiones y textos constituyen un importante corpus de estudio, que se une a una amplia colección de entrevistas realizadas durante dos años, con el fin de compartir una investigación que permita dar a conocer la contribución como docente e investigador de Javier Seguí en una etapa fundamental en la que la profesión de arquitecto se reinventa. 


\section{OBJETIVOS}

El objetivo principal de esta tesis es analizar de forma conjunta la trayectoria personal, académica y profesional de Javier Seguí de la Riva para averiguar las circunstancias que conforman su imaginario, descubrir los procedimientos que le permiten llegar al grado cero y analizar cada una de las acciones que, como intelectual, docente e investigador, justifican el desarrollo de esta investigación.

Además, poniendo especial atención en la actividad docente y pedagógica llevada a cabo por Javier Seguí en la E.T.S.A.M., se pretende reunir, sistematizar y clasificar todas las técnicas operativo-imaginarias desarrolladas durante los treinta y nueve años de vinculación con la Universidad y desvelar las técnicas operativas puestas en marcha en algunas de las prácticas más paradigmáticas del profesor. 


\section{METODOLOGÍA}

La tesis sigue dos métodos distintos para los dos ámbitos de conocimiento que la componen:

Respecto a la imaginación, imaginario y extrañamiento

\section{a. Recogida de información:}

Medios:

- Existentes: bibliográfico, audiovisual y consultas a expertos.

- De nueva creación: experimental.

Marco:

- Recorrido desde el mito de la caverna de Platón hasta Avatar, de James Cameron.

Hilo conductor:

- El imaginario como elemento que vertebra una aproximación multidisciplinar y multifacética.

- El extrañamiento como herramienta radical para alcanzar el grado cero.

b. Elaboración de contenidos

- Atlas relacional de imaginarios basado en palabras, lecturas y estrategias imaginarias.

- Redacción de texto interpretativo del atlas.

c. Búsqueda de metodologías aplicables a la docencia en arquitectura, basadas en la experiencia de Javier Seguí.

\section{Respecto a Javier Seguí}

\section{a. Recogida de información:}

Medios:

- Base bibliográfica.

- Base documental: archivo de Javier Seguí.

- Entrevistas semanales.

b. Elaboración del corpus de la investigación cruzando las variables de ambos campos.

Además de todas las publicaciones del propio autor, se han leído libros relativos a cada tema y se han realizado entrevistas fundamentales para asimilar sus palabras, y sus lecturas, con la intención de cartografiar su imaginario. Por último, se han elaborado cartografías a modo de síntesis de los datos recogidos. 


\section{ESTRUCTURA DE LA TESIS}

La estructura de la tesis recoge el recorrido realizado junto a Seguí en relación a su tiempo vital. Indaga en su pasado para averiguar las imágenes que han formado un imaginario que posteriormente necesita vaciar para poder dedicarse a una acción, desde el alejamiento de la extrañeza, basada en un ininterrumpido dibujar y escribir, como forma obsesiva de engañar al destino. En esta deriva, se producen ciertas paradas para observar ciertas imágenes, reflexiones y ejercicios desarrollados por el arquitecto en los últimos cuarenta años y que permiten entender algunos aspectos de la carrera de arquitectura impartida en la Escuela Técnica Superior de Arquitectura de Madrid.

De esta forma, la investigación se divide en tres partes, enunciadas como verbos, tal y como Javier Seguí lo haría: imaginar, reflexionar y hacer.

\section{Capítulo 1: Imaginar}

Se efectúa una aproximación a la imaginación como motor de los procesos creativos y objetivo principal de la docencia. Además se aborda no sólo su universo personal, sino también las teorías y los personajes que han influido en la formación de su imaginario.

\section{Capítulo 2: Reflexionar}

Se pretende mostrar el camino emprendido en su última etapa hacia el grado cero, mediante procesos de vaciamiento, para poder empezar a renombrar de nuevo aquellos elementos y situaciones que fundamentan lo arquitectónico, ahora en permanente estado de confusión.

\section{Capítulo 3: Hacer}

Se acompaña al arquitecto, al docente y al investigador en su actividad, para intentar descubrir su pedagogía, entender práctica docente y robar los enunciados de las técnicas operativo-imaginarias utilizadas durante su vida académica y profesional- También se comparte su estado actual como exiliado intelectual. 


\section{ESTADO DE LA CUESTIÓN}

La presente tesis pone de relieve varios temas investigados por tesis doctorales presentadas en años anteriores. Su base se sostiene sobre unos pilares fundamentales a la hora de crear un guión que valide la investigación.

Si se efectúa un repaso de las tesis doctorales presentadas en la E.T.S.A.M con temas relacionados con lo que se pretende tratar aquí, cabría destacar las que han supuesto un marco de referencia para el punto de partida de la presente.

Por un lado, resulta importante la docencia y, en particular, las transformaciones llevadas a cabo en la cátedra de Análisis de formas arquitectónicas por Javier Seguí. A este respecto, se cita la tesis de Javier Francisco Raposo, docente de la escuela.

RAPOSO, Javier Fco. Recopilación, estructuración y análisis de los documentos básicos manejados y elaborados en la cátedra de Análisis de formas arquitectónicas de la E.T.S.A.M a partir de los años 70. Aplicación a una nueva pedagogía. E.T.S. Arquitectura (UPM), 2004.

Su tesis, dividida en tres bloques, representa un importante punto de arranque con respecto a las innovaciones pedagógicas introducidas por Javier Seguí a lo largo de sus primeras décadas como docente de la E.T.S.A.M.

Para entender los cambios, es preciso contextualizar temas importantes que recojan sus argumentos y sus objetivos fundamentales. El archivo digital de la E.T.S.A.M. cuenta con dos tesis doctorales enfocadas a la enseñanza, en especial la que se centra en el dibujar.

RODRIGUEZ PULIDO, Alfonso. El dibujo en la enseñanza de la arquitectura. Las escuelas de arquitectura en México. E.T.S. Arquitectura (UPM), 2000.

PSEGIANNAKI EVANGELIA, Aikaterini. Contextualización teórica del acto pedagógico en la enseñanza y el aprendizaje del proyecto arquitectónico: el caso de la E.T.S.A.M. E.T.S. Arquitectura (UPM), 2015.

Para entender la acción pedagógica que emprende Javier Seguí con el objetivo de acercar el "dibujar" al "proyectar", es fundamental comprender las aproximaciones pedagógicas a su propuesta. En el mismo archivo digital se encuentran cuatro tesis doctorales sobre este tema.

KOSMA, Anthi. Proyectar dibujando: una aproximación fenomenológica al estado naciente del proyecto. Un estu- 
dio entre dos culturas arquitectónicas. E.T.S. Arquitectura (UPM), 2014.

MOSENA ARGOTE, Juan José. El dibujo y los sistemas de representación desde la Academia al Movimiento Moderno. E.T.S. Arquitectura (UPM), 1990.

MADERA SÁNCHEZ, Francisco Javier. De la academia a la escuela. El dibujo en la formación de los arquitectos de Madrid. E.T.S. Arquitectura (UPM), 1998.

LAPUERTA MONTOYA, José Maria de. Scintilla divinitatis. El croquis como herramienta proyectual en la arquitectura española contemporánea. E.T.S. Arquitectura (UPM), 1996.

Otro importante sostén relativo a la estructura pedagógica propuesta por Javier Seguí ha sido hallar en su imaginación -como desencadenante- y en su imaginario -como marco operativo- las referencias de sus procedimientos. El archivo digital mencionado recoge dos tesis doctorales que giran en torno a este tema.

GRIGORIADOU, Magdalini. El imaginario en la génesis del proyecto arquitectónico: la construcción de la realidad a través del mito, la utopía y la cibercultura. E.T.S. Arquitectura (UPM), 2014.

MILLARES ALONDO, Juan Miguel. El espacio imaginario. E.T.S. Arquitectura (UPM), 1989.

Asimismo, resulta interesante mencionar que en esta investigación resultan fundamentales los artículos de la revista $E G A$, así como muchos otros artículos publicados en los distintos Congresos de Expresión Gráfica Arquitectónica.

ABÁSOLO, Andrés, y Oscar Collado. "Reflexiones sobre experiencias piloto en dibujo, geometría y diseño de cara a la implantación del espacio europeo común EEES en los Planes De Estudio." Ega XII Congreso Internacional de Expresión Gráfica Arquitectónica (2008): 1-7, que expone un experimento relacionado con la fusión de las disciplinas graficas con las disciplinas no-gráficas.

AGUDO, Maria Josefa. "Dibujo y idea." Ega XII Congreso Internacional de Expresión Gráfica Arquitectónica (2008): 15-23, que nos reforzar la importancia de las emociones en la enseñanza y en el dibujo en particular.

AGUDO, Maria Josefa. "Dibujo y PBL." Ega XII Congreso Internacional de Expresión Gráfica Arquitectónica (2008): 2533 nos introduce los nuevos conceptos del plano de Boloña: PBL, ECTS, TIC's, refriéndose a las metodologías basadas en el cambio de actitud del profesor y del alumno, del fomentar del trabajo en grupo, del evaluar el proceso más que 
del resultado final y de adaptar el sistema de evaluación al nuevo método de enseño.

ALCAYDE, Rafael. "La discusión no está acabada. Otro punto de vista sobre el dibujo en la formación del arquitecto." Ega 17 (2011): 252-263 que trata de las varias teorías de la importancia del dibujo en arquitectura a lo largo de los siglos.

AMANN, Atxu, y Eduardo Vivanco. "De qué va esto. El entendimiento del aprendizaje genérico y arquitectónico.". Ega XII Congreso Internacional de Expresión Gráfica Arquitectónica (2008): 49-58, que exponen la necesidad de introducir y aceptar nuevas herramientas gráficas y el inevitable cambio del rol del profesor y del alumno.

APONTE CARRASCO, José, Luis Bravo Ferré, Joaquin Casals Coll, y Gustavo Contepomi. "Dibujar ¿Para qué? Notas para el debate sobre el papel de la formación gráfica en la carrera de arquitectura." Ega XII Congreso Internacional de Expresión Gráfica Arquitectónica (2008): 59-61.

ARRIBAS IRMA, Irma, Montserrat Bigas Vidal, Luis Bravo Farrë y Gustavo Contepomi. "Dibujo, imagen, tiempo, arquitectura.” Ega XIII Congreso Internacional de Expresión Gráfica Arquitectónica (2010): 53-58, tratan de plantear la adecuación de los programas a los nuevos programas del plan de Boloña, de aceptar el error como premisa necesaria a la evolución del conocimiento y de la necesidad de simular en las clases el funcionamiento de un estudio de arquitectura.

BALDRICH, José Ma Gentil. "La interpretación de la "Scenografia" Vitrubiana o una disputa renascentista Sobre EI Dibujo Del Proyecto." Ega 1 (1993): 15-33, comenta los inicios del dibujo de arquitectura y de la perspectiva.

BARKI, José. "Diagrama como discurso visual: uma velha técnica para novos desafios." Ega XIII Congreso Internacional de Expresión Gráfica Arquitectónica (2010): 77-82, reitera la importancia del diagrama en la enseñanza y en el aprendizaje.

BARRERA MARTÍNEZ, Enrique. "Elogio de la Imperfección." Ega XIII Congreso Internacional de Expresión Gráfica Arquitectónica (2010): 83-88, hacen una importante reflexión sobre la importancia del error y de la imperfección en la forma de aprender y comunicar determinada información gráfica.

BURGALETA MEZO, Pedro. "Imagen icónica, imagen fantasmática. Reflexiones para el desarrollo de una pedagogía poética." Ega XII Congreso Internacional de Expresión Gráfica Arquitectónica (2008): 119-121, pon en evidencia la importancia de la imaginación y de las imágenes difusas y 
fantasmáticas como el impulso de una nueva poética pedagógica.

CHÍAS, Pilar. "La caligrafía de Mercator y otras singularidades de la rotulación de Mapas." Ega 13 (2008): 82-93, que nos relata la importancia de instrumento en la ejecución gráfica.

FLORIDO, F. León. "Forma y dibujo. Notas para una fundamentación filosófica del proyecto." Ega 6 (2001): 16-30, donde expone relaciones entre geometría, ciencia e imaginación como técnica ancestral del dibujar.

GOMBRICH, Ernst Hans. "Historia del arte y psicología en Viena, hace cincuenta años." Ega 1 (1993): 38-41, que nos habla de la psique como determinante de la percepción óptica y de porque la representación ha prevalecido por encima de todo el resto.

MEDEROS MARTÍN, Francisco. "El dibujo como medio didáctico atemporal." Ega XIII Congreso Internacional de Expresión Gráfica Arquitectónica (2010): 293-297, hace una interesante conexión entre imaginación y arquitectura como un diálogo atemporal.

MILLÁN GÓMEZ, Antonio. "Equivalencias: arquitectura, diagramas y el rechazo de lo icónico.". Ega XIII Congreso Internacional de Expresión Gráfica Arquitectónica (2010): 299-303, nos aporta nueva información relativamente a los diagramas e iconos en arquitectura.

MONEDERO, Javier. "Nota sobre la idea de analogía y su posición fundamental para una teoría de la expresión gráfica." Ega 1 (1993): 42-46, donde expone la potencialidad expresiva del Color y de la Forma en la composición gráfica.

MONEDERO, Javier. "Sobre La incomodidad del arte y otras imposturas académicas." Ega 6 (2001): 63-69, relata la inadecuada tendencia actual de alejar el proyecto del dibujo.

MORÁN ORTEGA, Adolfo, y Fernando Morán Ortega. "La imaginación arquitectónica y la "muerte del dibujo"." Ega XIII Congreso Internacional de Expresión Gráfica Arquitectónica (2010): 311-315.

PUEBLA PONS, Juan y Victor Manuel Martínez López. "El diagrama como interface del proyecto arquitectónico." Ega XIII Congreso Internacional de Expresión Gráfica Arquitectónica (2010): 351-355, habla de cómo el diagrama es una herramienta fundamental de cara al dibujar.

SEGUÍ, Javier. "Propuestas de convenciones estructuradoras para la enseñanza del dibujo y la iniciación al proyecto 
en los nuevos planes de estudio." Ega 6 (2001): 31-41, expone sobre las atenciones arquitectónicas y de cómo el dibujo arquitectónico no debe reducirse apenas a su destreza y técnica pero tampoco a su grafismo desinteresado.

SEGUÍ, Javier. "Anotaciones para un imaginario del dibujar." Ega 13 (2008): 70-81, que nos revela una importante visión sobre el dibujo en planta, en presencia (alzado) y en sección.

SEGUÍ, Javier. "Para una poética del dibujo." Ega 2 (1994): 59-69, habla de modalidades comunicativas: representación, expresión e interpretación y de la relación entre el soporte y el dibujante.

SOLANA, Enrique. "Dibujo y proyecto; mística, emoción, razón e Interpretación." Ega 6 (2001): 42-51, aporta una importante visión sobre la importancia de la interdisciplinariedad y de la aclamada genialidad como castradora de la enseñanza.

TORDESILLAS, Antonio Álvaro y Begoña Cuesta Llaneza. "Muerte a los prejuicios." Ega XII Congreso Internacional de Expresión Gráfica Arquitectónica (2008): 41-49, trata de evidenciar la importancia del ordenador como herramienta fundamental del dibujo de ideación

VERD HERRERO, Antonio. "Hazlo conmigo. Iniciación al aprendizaje del proyectar (de los arquitectos).". Ega XII Congreso Internacional de Expresión Gráfica Arquitectónica (2008): 851-856, dejando en evidencia una vez más la importancia del rol entre profesor y alumno.

VIDAL, Montserrat Bigas y Luis Bravo Farré. "Dibujo, imagen e arquitectura. Notas sobre el inicio del proceso gráfico del proyectar en Aalto Y Miralles." Ega 13 (2008): 150-159, explora la técnicas operativo-imaginarias de la pos-producción, cruzamiento y ficción, acomodadas por arquitectos reconocidos como Aalto y Miralles.

En la fusión de estos pilares reside la originalidad de este trabajo de investigación y el hilo conductor del relato. Javier Seguí es el vertebrador de diversas innovaciones planteadas durante la posesión de su cátedra, innovaciones que pretenden constituir un importante marco académico para la enseñanza de la arquitectura y seguir favoreciendo nuevas formas de optimizar la enseñanza de lo arquitectónico. 



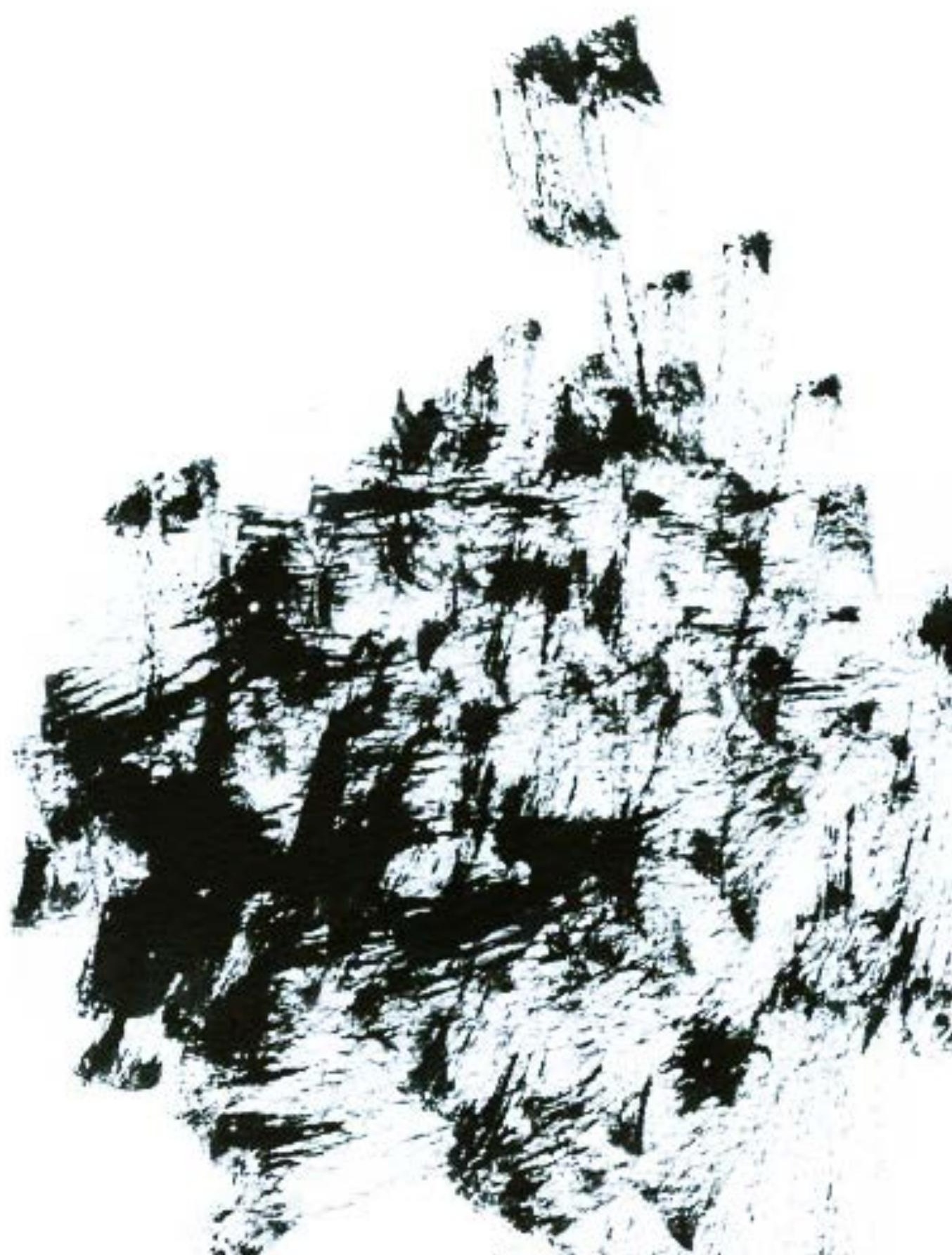




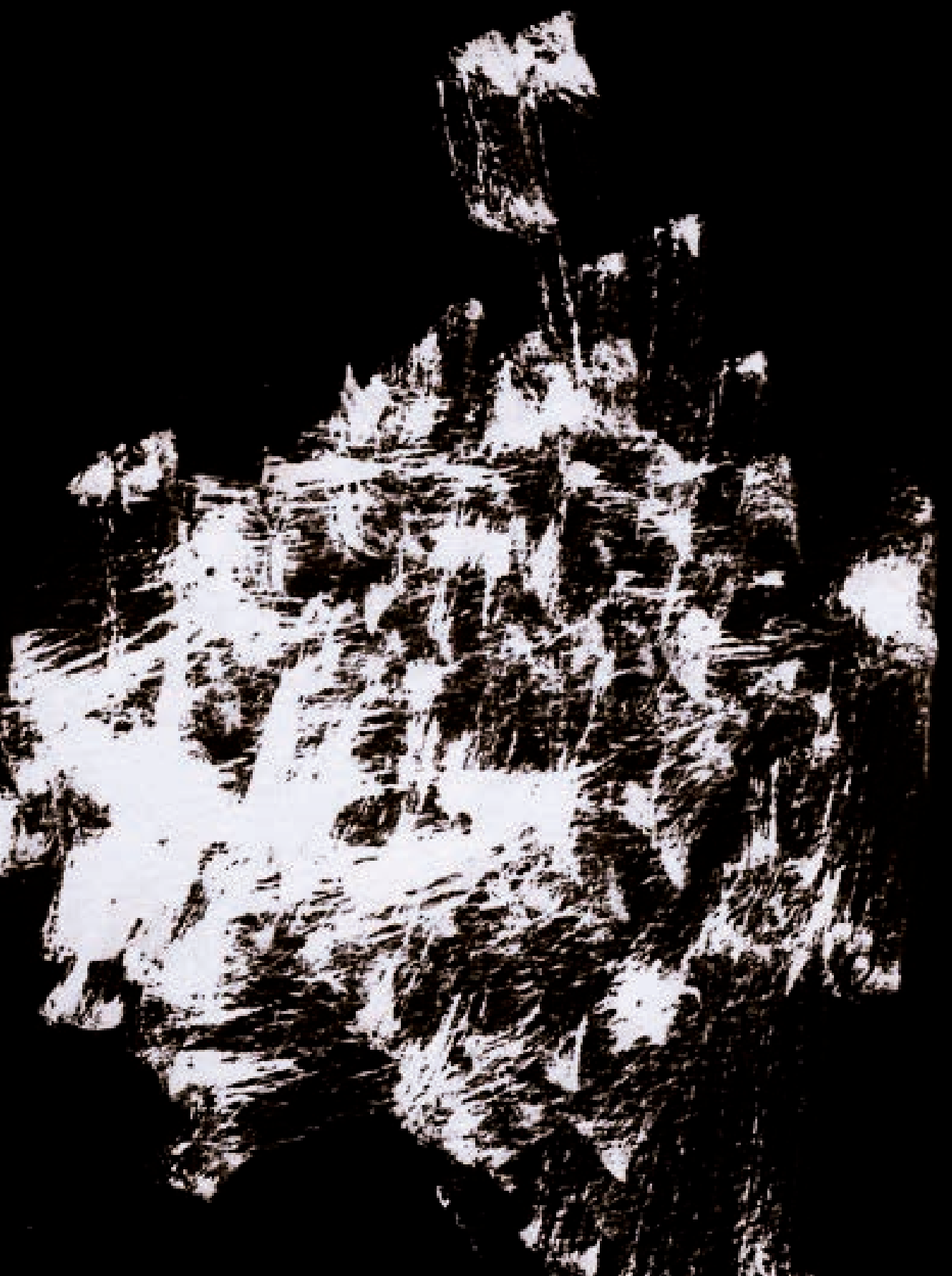


1.imaginar 
Las figuras imaginarias tienen más relieve y verdad que las reales. Mi mundo imaginario ha sido siempre el único mundo verdadero para mí. Nunca he tenido amores tan reales, tan llenos de vigor de sangre y de vida como los que he tenido con figuras que yo mismo he creado. ¡Qué pena! Siento añoranzas de ellos, porque, como los demás, pasan...²

Imagen, imaginación e imaginario son los términos fundamentales del capítulo que aquí se presenta. Siguiendo el pensamiento de Gibert Durand, la imagen es carburante de la imaginación y responsable de la representación mental del objeto o de hallarse en su ausencia. Una representación, consciente o inconsciente, generada a partir de percepciones y recuerdos, está en constante mutación, adecuándose a las vivencias experimentadas en cada momento. "La imaginación es el motor que hace que la máquina imaginal funcione; y el imaginario, el denominador fundamental de los procedimientos del pensamiento humano." ${ }^{3}$

El imaginario y la imaginación son para Javier Seguí objetos fundamentales de investigación a lo largo de su carrera como docente. Pero además, Seguí posee un imaginario particular, formado precisamente por todas las experiencias e imágenes acumuladas en su imaginario durante muchos años y que, ahora, desde el extrañamiento, salen a la superficie para ser analizadas y clasificadas.

En el momento actual, respaldados por el conocimiento científico sobre el funcionamiento del cerebro, no se puede encarcelar la imaginación en unos psiquismos concretos tallados por facultades intelectuales, emocionales o volitivas. Todas son parte integrante e inseparable de su funcionamiento. La imaginación opera según su estímulo interno o externo, su consciente o su inconsciente, según su sabiduría intelectual o sus imágenes oníricas. "Evoca" imágenes, pero también las "crea". 
imaginar

\section{1 imaginación}

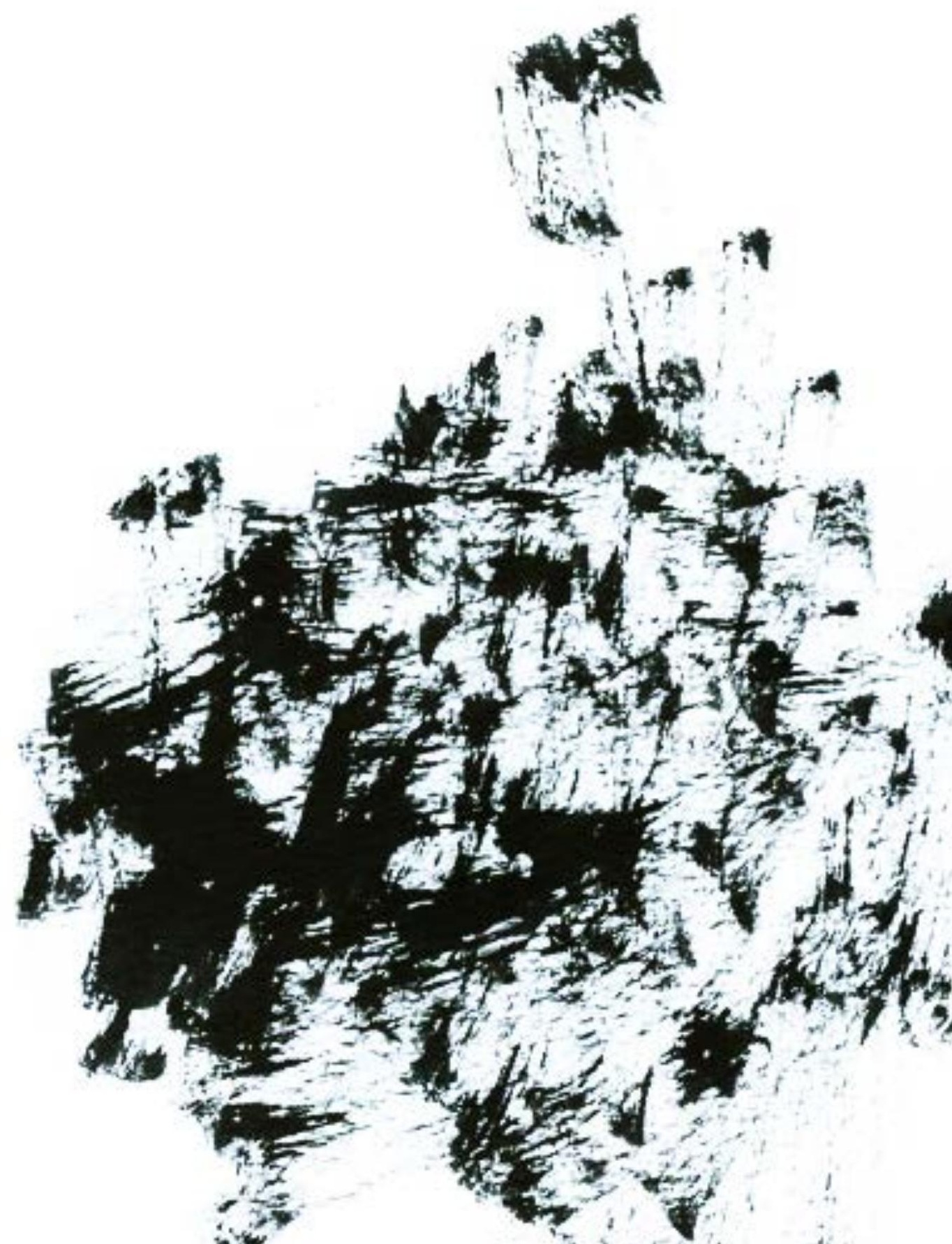


Yo creo que la imaginación es todo. Todo es imaginación. Esa cosa misteriosa que es estar vivo es estar imaginando. Luego se convierte en inteligencia, en fantasía, en operatividad, en metodología, en estrategia. ${ }^{4}$

El estudio de la imaginación empieza en el siglo VI a.C. de la mano de Platón. El filósofo la considera en su momento como el grado inferior del conocimiento. Un siglo más tarde, otro filósofo griego, Aristóteles, en su tratado Acerca del Alma, perteneciente al Libro III, afirma que "el alma nunca piensa sin fantasmas"; imposible pensar sin imaginación. La imaginación sigue siendo tema de investigaciones en el ámbito filosófico y ya en el siglo $\mathrm{XVI}$ surgen las discusiones más encendidas a este respecto. Según cuenta Ferrater Mora, para Francis Bacon, la imaginación es una facultad que se descubre en la poesía. Para Descartes, es el motor generador de imágenes sin necesidad de conciencia. Kant resume la imaginación como una síntesis que unifica la diversidad de la intuición que no da origen al conocimiento, pero sin la cual, éste no es posible. Jean-Paul Sartre la ve como un "acto sintético que une un saber concreto que no tiene carácter de imagen, a elementos más propiamente representativos."

En la afirmación de Sartre, se repara en que la imaginación no es propiamente fantasear, porque la síntesis hecha por la imaginación sólo es posible con un material previamente sintetizable. Es aquí donde se construye el puente entre la imaginación como capacidad de combinar ideas y el conocimiento, que es la idea en sí misma y la consecuencia de la función cognoscitiva. Pero, el considerar la imaginación como "consciencia imaginante", ignora una parte muy importante de su modus operandi, que tiene que ver con el universo oculto tras la consciencia y que Freud destapa medio siglo antes (1896).

La imaginación depende de diversos hechos psíquicos y puede ser activada a través de una imagen, un concepto, un recuerdo, una emoción, un olor. La dimensión del psiquismo es dinámica y fluida, variable e intencionada. En este sentido, Freud introduce una nueva variante en el juego de la imaginación, que denomina inconsciente.

Con la aparición del inconsciente, llega también todo un universo que se encuentra detrás de lo conocido de manera consciente y

\footnotetext{
4 Javier Seguí, entrevistado por Maria Brito, 4 de marzo, 2014.

5 Aristóteles, De anima III, 7, cit. en Cornelius Castoriadis, Los dominios del hombre, trad. Alberto L. Bixio (Barcelona: Gesida, 1998), 152.

6 Jean-Paul Sartre, O Imaginário. Psicologia Fenomeológica Da Imaginação. (São

Paulo: Editora Ática S.A., 1996), 21.

Sartre, O Imaginário. Psicologia Fenomeológica Da Imaginação, 21.
} 
que se reprime por cuestiones sociales o emocionales: lo que el imaginario social rechaza.

Para Freud, esta nueva dimensión del pensamiento es también responsable de algunos procesos patológicos de la maquinaria mental ya que, el imaginario personal produce imágenes que condicionan el pensamiento y que fundan la realidad conocida.

Con el tiempo, las nuevas propuestas incluyen la imaginación en el dinamismo del conocimiento, convirtiéndola en su aliada. A ella se asignan funciones de memoria y coordinación de las imágenes necesarias para el procesamiento de la gnosis. Más tarde, y con Bachelard, la imaginación alcanza la categoría elemental del entendimiento.

El fondo vital es la imaginación, lo que se llama consciencia cósmica. Eso es la imaginación. Nada más. Lo que pasa es que la imaginación tiene muchas vertientes. Entonces, en un momento determinado, se convierte en inteligencia. Pero la imaginación es la fantasía, la capacidad metafórica, el hecho de poder conectar cosas, la capacidad analógica. ${ }^{8}$

Etimológicamente, la palabra imaginación, viene de "imagen", del latín "imago" (retrato), imitación de lo real. Imaginación, con el sufijo "-ción" significa "la facultad de hacer o representar las imágenes de los objetos visibles". ${ }^{9}$

Cuando el pintor Vincent van Gogh escribe sobre su famoso cuadro, La habitación de Vicent en Arlés, dice sobre ella:

Tengo una nueva idea en la cabeza y aquí está el boceto... esta vez se trata sencillamente de mi dormitorio; aquí sólo debe operar el color, y dándole un mayor estilo a las cosas por su simplificación, ha de sugerir el reposo o el silencio en general. En una palabra, al contemplarse el cuadro debe descansar el pensamiento, o mejor aún, la imaginación. ${ }^{10}$

Si se acude al Diccionario de la Real Academia Española, en su definición actual, se encuentran tres significados:

Imaginación - (Del lat. imaginatîo,-önis).

1. f. Facultad del alma que representa las imágenes de las cosas reales o ideales.

2. f. Aprensión falsa o juicio de algo que no hay en realidad o no tiene fundamento.

\footnotetext{
8 Javier Seguí, entrevistado por Maria Brito, 10 de diciembre, 2013, Grabación.

9 Agustín Gutierrez, "De la imaginación," en Curso completo de filosofía elemental (Santander: 1866).

10 Vicente van Gogh citado en E.H. Gombrich, "En busca de nuevas concepciones.

Final del siglo XX," en Historia del arte (México: Editorial Diana C.A, 1995), 548.
} 
3. f. Imagen formada por la fantasía.

4. f. Facilidad para formar nuevas ideas, nuevos proyectos, etc. ${ }^{11}$

Analizando las acepciones primigenias del concepto, se encuentran en el Diccionario de Filosofía de José Ferrater Mora varias referencias:

(...) la imaginación es una facultad (o, en general, actividad mental) distinta de la representación y de la memoria, aunque de alguna manera ligada a las dos: a la primera, porque la imaginación suele combinar elementos que han sido previamente representaciones sensibles; a la segunda, porque sin recordar tales representaciones, o las combinaciones establecidas entre ellas, no podría imaginarse nada. (...) La imaginación es, en rigor, una representación (en el sentido etimológico de este vocablo), es decir, una nueva presentación de imágenes. ${ }^{12}$

La imaginación es "ese poder misterioso y admirable"13 capaz de hacer que el ser humano adquiera una inteligencia insospechada. Muchas veces confundida con la memoria por su capacidad de transportar las representaciones de los objetos, es bastante más que un reproductor de imágenes; se trata de una facultad especial para combinar ideas de una manera absolutamente innovadora.

En la Edad Media eran las facultades del alma, el entendimiento de la voluntad, la razón. Pasa dentro una reacción que suscita imágenes, recuerdos, ecos, palabras. Eso se llama imaginación, y se nombra cuando eres especialista en una determinada cosa. Se llama inteligencia cuando se usa la imaginación para conectar cosas. Se llama razón cuando esa cosa entra dentro de una formulación. Se llama memoria cuando la imaginación es justamente la evocación de situaciones anteriores. Todas las facultades del alma son modalidades de la imaginación. Y lo que hay dentro de la imaginación para que sea posible su dinamización es lo que llamamos imágenes; como por ejemplo la e-moción, que es algo que lleva a moverte. ${ }^{14}$

Resulta también habitual la confusión entre la imaginación y las materias en las que se convierte. La fantasía y la ficción son las más frecuentes, dada su similitud conceptual. Pero ni fantasía ni ficción son imaginación. Para Javier Seguí, ficción es el no-lu-

\footnotetext{
11 Real Academia Española, "Imaginación," 20 de marzo de 2015: http://lema.rae.es/ drae/srv/search?key=imaginaci\%C3\%B3n.

12 Ferrater Mora, Diccionario de filosofia (Buenos Aires: Editorial Sudamerica,1965),913.

13 Gutierrez, "De la imaginación," 260.

${ }^{14}$ Javier Seguí, entrevistado por Maria Brito, 5 de mayo, 2014, Grabación.
} 
gar; es la atmósfera del proyectar, el "ámbito de referenciación flotante, contraria, ambigua, abierta, implicada", ${ }^{15}$ el "entre" del vivir; y fantasía, la propiedad de la imaginación que la sublima.

Ficción.- Acción y efecto de inventar cosas fingidas (sic).

Las ficciones operan e inventan realidades alternativas.

Fantasía.- Facultad que tiene el ánimo de reproducir, por medio de imágenes, las cosas pasadas o lejanas, de representar los ideales en forma sensible, o de idealizar las reales; fantasmagoría, ilusión de los sentidos; la imaginación en cuanto inventa o produce; ficción, etc. (sic).

Algunos autores entienden la fantasía como una modalidad de la imaginación orientada a la idealización o la ficción. En sentido peyorativo, la fantasía sería la imaginación evasiva, la imaginación al margen de las leyes naturales o del principio de realidad. ${ }^{16}$

La imaginación es más que producción y articulación de imágenes. Tiene una función primordial en el acto proyectivo, pues es la impulsora de la acción. Se puede decir que sin imaginación no hay acción porque, tal y como lo entiende Bachelard, la imaginación dinámica capta las imágenes, les da nuevos significados que luego se traducen en las metáforas.

Aunque se suele asociar al sentido de la vista, todos los sentidos aportan materia sintetizable a la imaginación: las sensaciones, las emociones y el propio cuerpo son hilos conductores de su complejo engranaje. "Imaginación es figuración difusa y mecáni$\mathrm{ca}$, provocada por el movimiento y las sensaciones convocadas en cada experiencia." ${ }^{17}$

La imaginación, por su capacidad de combinar la materia intelectual y emocional, es una herramienta primordial a la hora de crear y razonar. Pero, ¿cómo se selecciona la realidad? ¿Cómo se aprehende? ¿Qué procesos subyacen tras su abstracción? ¿Por qué razón se desarrollan determinadas combinaciones en detrimento de otras? ¿Qué define el carácter de originalidad? "Imaginar es significar... Cambiar contextos, tantear ámbitos de atención, cambiar escalas, referentes, operaciones, etc. Intensificar, radicalizar, caricaturizar."18

\footnotetext{
15 Javier Seguí,"La Imaginación (1) (31/07/10)," (Madrid: Instituto Juan Herrera de la Escuela de Arquitectura de Madrid, 2010).

16 Javier Seguí,"Glosario de términos (15-04-96)," (Madrid: Instituto Juan Herrera de la Escuela de Arquitectura de Madrid, 1996).

17 Seguí, "La imaginación (1) (31/07/10)."

18 Seguí, "La imaginación (1) (31/07/10)."
} 
Nietzsche dice que la realidad es lo que cada grupo entiende como tal y su verdadera esencia es la voluntad. Voluntad que, como comenta Seguí, no se puede manejar "si no se tiene la imaginación de a dónde se quiere llegar." 19 La realidad no puede ser estática e inmutable porque su aprehensión es variable y dinámica. Por ese motivo, también la imaginación actúa en cada individuo de manera distinta, y su dinámica se identifica con los intereses y aptitudes de cada uno. Así, no sólo el exterior influye en la imaginación, sino también las cuestiones intelectuales, físicas, orgánicas y sociales.

La capacidad de modificar y conectar interior con exterior es lo que usualmente se denomina imaginación. ${ }^{20}$ Entre el ser humano y el exterior hay una interacción constante que tiene que ver con entrar en contacto con lo que está fuera de uno mismo:

En una relectura de Maturana sobre la biología del conocimiento y la autopoiesis, entendemos el ser humano como algo cerrado en sí mismo que interactúa con el exterior y que de alguna manera va transformando el exterior y su medio apoyado en el lenguaje. ${ }^{21}$

La imaginación es el intermediario de la interacción con el exterior. Es la forma en la que se percibe el mundo y se establecen las relaciones con los demás.

El hombre no es sólo un ser racional y creyente, ni tampoco un homo faber et consumens, pues, no menos que todo eso, sigue siendo un animal sintiente e imaginante y, por ello, el dominio de sí mismo, su armonía interior, su felicidad, en suma, dependen del arte con que maneje sus representaciones, imaginaciones y sentimientos. Es decir, el arte con que coordine y disponga los objetos que reposan en el complejo espacio de su identidad personal. ${ }^{22}$

En cuanto a su relación con la ciencia, la imaginación desempeña un papel fundamental en el campo científico y en el de la reflexión, porque es el "lugar de ensayos tentativos". ${ }^{23}$ El método científico, conocido por sus distintas etapas de concepción, nunca podría llegar a su conclusión si la imaginación no funcionara como el motor que activa la observación y la elaboración de hipótesis; una imaginación que reflexiona y se apoya en la razón para buscar la solución adecuada a un problema.

\footnotetext{
19 Javier Seguí, "Encuentros. Comentarios, reducciones, anotaciones, conversaciones," (Madrid: Instituto Juan Herrera de la Escuela de Arquitectura de Madrid).

20 Javier Seguí, entrevistado por Maria Brito, 17 de diciembre, 2013, Grabación.

21 Seguí, 5 de mayo, 2014.

22 Ignacio Gómez de Liaño, Filósofos griegos, videntes judíos

(Madrid:Siruela,2000), 343.

23 Seguí, "La imaginación (1) (31/07/10)."
} 
Así, Arte y Ciencia no están tan alejados entre sí como se hace creer. Ambos comparten el mismo contenido mental generador de pensamientos: la imaginación. En ambos casos, la imaginación es la que sostiene la comprensión y el estudio de lo invisible; la que permite elaborar modelos coherentes que respondan a las inquietudes del mundo. En física cuántica, por ejemplo, las partículas dejan de hacer trayectos lineales y aparecen y desaparecen en otras partículas. Entender este fenómeno sólo es posible si se es capaz de imaginar lo invisible.

La imaginación funciona como herramienta conciliadora entre lo visible y lo invisible, lo posible y lo aparentemente imposible, creando una dinámica de contingencias y ensayos virtuales fundamentales en ambos casos: se tiene que dar el vertiginoso salto al vacío para encontrar lo que aún está oculto.

En unas conferencias, un físico amigo mío, Pedro Echenique, (...) dice: "la ciencia hace especial uso de la imaginación. Los grandes descubrimientos no son lógicos nunca." Dice también otra cosa absolutamente fundamental: "los descubrimientos científicos desvelan implicaciones, conexiones, además alumbran secretos e incitan cambios. La ciencia, como el arte, encuentra respuestas sin preguntas. Pero, sobre todo, encuentra respuestas a preguntas. ${ }^{24}$

Arthur Miller establece una relación entre la Relatividad de Einstein (1905) y el cuadro Les Demoiselles d'Avignon (1907). Mientras que el teorema de Einstein trata de representar fenómenos que ocurren simultáneamente en distintos lugares, también Picasso y el cubismo intentan plasmar distintas vistas y perspectivas en un mismo cuadro. Ambas teorías concluyen simultáneamente que la perspectiva depende de cómo y desde dónde se mire el objeto. ${ }^{25}$

La imaginación actúa en diversos niveles y contextos. En la vida de vigilia participa en preceptos, recuerdos, conceptos, lenguaje..., en el ensueño, en el sueño, en la creación artística o en la invención científica; en las creencias colectivas (mitos), en los proyectos utópicos. En rigor, no queda rincón de la actividad humana que no esté penetrado por procesos imaginativos. ${ }^{26}$

Por lo tanto, la imaginación cumple los requisitos exigidos tanto por el pensamiento artístico como por el científico, ya que posi-

\footnotetext{
24 Javier Seguí, entrevistado por Maria Brito, 28 de octubre, 2014, Grabación.

25 Arthur Miller, Picasso: Space, Time and the Beauty That Causes Havoc (New York: Basic Books, 2001).

26 Maria Noel Lapoujade, Filosofía de la imaginación (México: Siglo XXI Editores, 1988), 21.
} 
bilita la "creación de objetos en un sistema simbólico"27 fundamental para generar representaciones mentales del mundo ${ }^{28} \mathrm{y}$ configurar sus posibilidades teniendo en cuenta la manera en la que cada uno percibe el mundo (imaginario). ${ }^{29}$

La imaginación es una propiedad humana fundamental, no sólo para formar imágenes, sino también para relacionarlas. Bachelard dice, incluso, que la imaginación no forma imágenes, las deforma; las une de manera inesperada, impulsa la vida y la movilidad espiritual, dándoles un trazado cinético y dinámico. ${ }^{30}$

Puedo imaginarlo todo, porque no soy nada. Si fuese algo, no podría imaginar. El ayudante de contabilidad puede soñarse emperador romano; el Rey de Inglaterra está privado de ser, en sueños, otro rey distinto del rey que es. Su realidad no le deja sentir. ${ }^{31}$

En la gran maquinaria de la imaginación reside el vasto erario de la humanidad. Es energía, el lenguaje de los poetas o, como decía William Blake, el momento en el que Dios opera en el alma humana. La capacidad de crear nuevas formas reveladoras de realidades invisibles, unificando la armonía de su pensamiento con la incertidumbre. Seguí agrega, además, que "cuanto más comprensibles son los acontecimientos o las formulaciones, tanto más se disipan la imaginación y la verborrea para interpretarlos." 32

Sin embargo, actualmente, la ciencia, el poder, la religión o la ideología producen la amputación de esa fuerza inefable a la que se denomina imaginación. El sistema de enseñanza actual está organizado a tenor de ese mismo sistema. Para Javier Seguí, el estímulo de la imaginación debe ser uno de los principales objetivos de la enseñanza, ya que, "formar a una persona es activarla, es motivarla para que sea capaz de imaginar ${ }^{33}$ y que "enseñar, aprender, o hacerse mayor, no es más que aprender a imaginar."34

\footnotetext{
27 Giles-Gaston Granger, "Imaginação Poética, Imaginação Científica," Discurso 29 (1998): 7.

28 Jacob Bronowski, O Olho Visionário: Ensaios Sobre Arte, Literatura E Ciência (Brasí-

lia: Editora UnB, 1998).

29 Gilbert Durand, L'imaginaire. Essai Sur Les Sciences Et La Philosophie De L'image (Paris: Hatier, 1994).

30 Gastón Bachelard, El aire y los sueños - Ensayo sobre la imaginación del movimien-

to, trad. Ernestina de Champorcine (México: Fondo de Cultura Economica, 1993).

31 Pessoa, Libro del desasosiego, 193.

32 Javier Seguí, entrevistado por Maria Brito, 8 de abril, 2014, Grabación.

33 Seguí,"Encuentros. Comentarios, reducciones, anotaciones, conversaciones."

34 Seguí, 4 de marzo, 2014
} 
imaginar

\section{2 imagen}

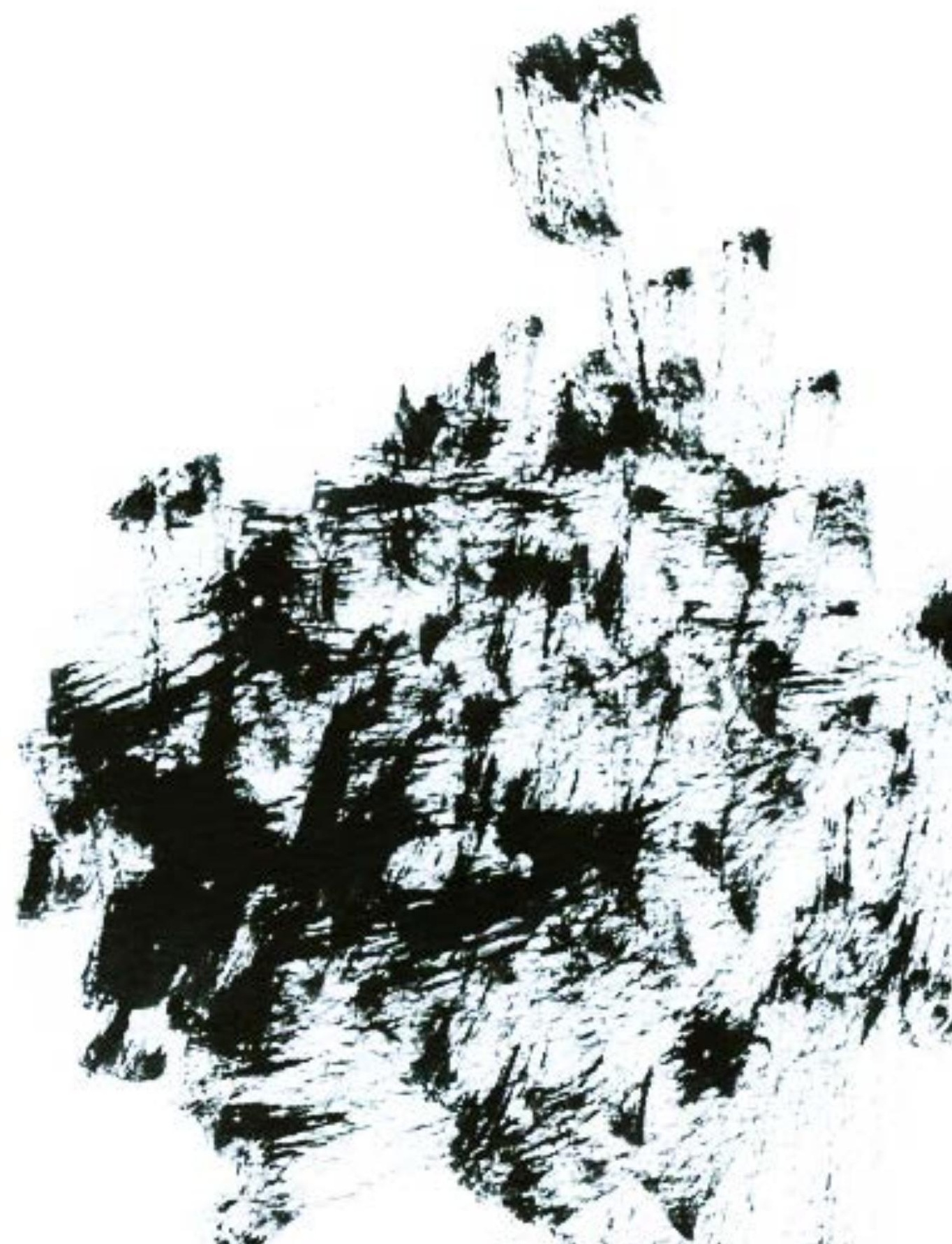


La imaginación o el conocimiento de la imagen llegan a través del entendimiento; es el entendimiento aplicado a la impresión material del cerebro, lo que nos da la consciencia de la imagen. ${ }^{35}$

Hablar sobre la imaginación como la "facultad del alma que representa las imágenes de las cosas reales o ideales"36 supone, en primer lugar, entender la dinámica de la imagen con el pensamiento. Sobre este razonamiento, Javier Seguí escribe en su Glosario de conceptos, de 1996, que una imagen es realmente significativa cuando es capaz de convertir la condensación analógica contemplada -lo que el individuo ve-, en imaginación dinámica.

Para deconstruir la idea de que el origen de la imagen es exclusivamente perceptivo, Ricœur dice que, si se concibe, no como percepción, como huella que desvanece lo real (visual); sino como una metáfora (hablada) o resonancia de significados, la imaginación es, sin lugar a dudas, la herramienta necesaria para esquematizar esa atribución. ${ }^{37}$

También Constance Classen, antropóloga especializada en la Historia de los Sentidos y profesora de la Universidad de Harvard, afirma que la imagen no es una derivación de la percepción; no es la "escena de algún teatro para un espectador interior." 38

El concepto de imagen sufre distintos cambios e interpretaciones desde que Platón le llama "simulacro fantasmal", en clara oposición al conocimiento ${ }^{39}$ o desde que Baruch Spinoza diga que son meras "afecciones del cuerpo humano cuyas ideas no representan los cuerpos exteriores presentes". ${ }^{40}$

En la Filosofía Moderna que se desarrolla en Europa a lo largo del siglo XVIII, destacan dos corrientes con distintas opiniones sobre esta temática: por un lado, el Racionalismo, que afirma que la imagen es opuesta al entendimiento y al pensamiento; una sensación ajena a todas las significaciones lógicas propias del pensamiento científico; por otro, el empirismo, que afirma que el

\footnotetext{
35 Jean-Paul Sartre, A Imaginação, trad.Paulo Neves(Porto Alegre: RS:L\&PM, 2008),13.

36 Seguí, "Glosario De Términos (15-04-96)."

37 Paul Ricœur, Del texto a la acción, trad. Pablo Corona (Buenos Aires: Fondo de Cltura Economica, 2001).

38 Seguí, "La Imaginación (1) (31/07/10)."

39 José Ricardo Morales, Arquitectónica. Sobre la idea y el sentido de la arquitectura

(Chile: Universidad del Biobio. Facultad de arquitectura y construcción., 1984).

40 Boris Eremiev, "Filosofia Da Arte Na Teoria Do Conecimento De Spinoza," en Spino-

za. Tercer Coloquio (Córdoba: Brujas, 2007), 263.
} 
conocimiento resulta de la suma de la razón, la experiencia y la percepción.

El racionalista Descartes dice que la imagen es "una cosa corporal, producto de la acción de los cuerpos exteriores sobre nuestro propio cuerpo por intermedio de los sentidos y de los nervios", ${ }^{41}$ a lo que Leibniz añade diciendo que las imágenes - 0 ideas confusas - viven en el alma y, por lo tanto, no pertenecen al mundo de la razón. Para estos autores, la imagen es turbia e infinita y por eso contraria a la idea clara, finita y analizable de la razón. Sin embaro, para Javier Seguí, la peor tradición filosófica es justamente aquella que "entiende la imagen como percepción debilitada de la realidad." 42

Para Gastón Bachelard las imágenes son incluso anteriores al pensamiento, instancias primeras del psiquismo, los conceptos y el pensamiento vienen más tarde. ${ }^{43}$ Para el filósofo alemán Martin Seel, "las imágenes son superficies abarcables en la mirada, superficies que hacen visible algo," 44 el producto final del arte de la expresión y de la comunicación. ${ }^{45}$

En su libro Imaginación e invención, Simondon dice que la imagen es todo lo que ocurre en el interior del individuo. De hecho, habla de tres estadios precedentes.

(...) tres estadios anteriores del ciclo de la imagen; la proyección amplificante de la tendencia motriz, antes de la experiencia del objeto, es una hipótesis implícita de despliegue en el mundo; las claves perceptivas que sirven de sistema subjetivo de recepción a la información incidente postulan una amplificación universal; por último, el lazo simbólico de las imágenes-recuerdos, en tanto expresa en la dirección centrípeta, el apego del sujeto a las situaciones que han constituido su historia, prepara a su vez y sobre todo el uso de la reversibilidad que lo convierte en vía de acceso hacia las cosas. ${ }^{46}$

El concepto de imagen varía continuamente a lo largo de la Historia. Lo que en el pasado es simplemente una representación de la realidad, adquiere ahora distintas magnitudes al añadir nuevas maneras de entenderla y percibirla.

\footnotetext{
Sartre, A Imaginação, 13.

42 Seguí, "La imaginación (1) (31/07/10)."

43 Tomás Ibáñez Gracia, "Elogio de la imaginación " Quaderns de Psicología vol.11 (2009): 44.

44 Martin Seel, Estética del aparecer (Buenos Aires: Katz editores, 2010), 266.

45 Javier Seguí, Dibujar, proyectar (LVIII) - El imaginario del dibujar (Madrid: Instituto Juan de Herrera de la Escuela Técnica Superior de Arquitectura de Madrid, 2013), 15.

46 Gilbert Simondon, Imaginación e invención, trad. Pablo Ires (Buenos Aires: Cactus Serie Clases, 2013).
} 
Sobre este infinito universo alrededor del mundo imagético, Javier Seguí piensa también que las imágenes pueden ser representaciones objetivas -figuras, cosas-, pero también anímicas -imágenes mentales-; una especie de realidad interna vinculada a impresiones externas o "esquemas subjetivos que se viven como recuerdos de fragmentos representativos, asociados con esquemas dinámicos y afectivos diversos." 47

Las imágenes pueden existir en dos planos distintos: como representaciones objetivas, cuando se hacen acompañar de su existencia -"imágenes externas"-; y como representaciones psíquicas -"imágenes mentales"-, cuando dejan de existir en sí por ausencia de la mirada. Para Husserl ambas tienen como misión rellenar los vacíos del conocimiento, no importa si esos vacíos se llenan mirando el objeto o evocándolo, sino su significación. ${ }^{48}$

\begin{abstract}
El estudio de la imaginación es complejo, pero creemos que es importante atender a la dinámica que se produce entre las imágenes mentales y las configuraciones (imágenes objetivas), prestando especial interés en significar que algunas imágenes objetivas desencadenan la acción proyectiva más fácilmente que otras. ${ }^{49}$
\end{abstract}

A Javier Seguí le importan sobre todo las "imágenes gráficas", las producidas por el acto de dibujar, aunque le interese más su proceso, el movimiento que genera su "hacer", que su imagen final terminada. Dentro del mundo de las imágenes, resalta un grupo concreto a las que denomina "imágenes-fuerza": imágenes que "cuando las ves no las puedes olvidar, porque "se te quedan ahí clavadas." ${ }^{50}$ Se tratan de imágenes que impresionan, se fijan en el cerebro y, por tanto, se recuerdan siempre.

Buscar el almacén de las "imágenes-fuerza" es una operación importante, no sólo para destapar el imaginario, sino también para entender los procedimientos proyectuales de cada uno. Analizarlas y saber cómo se forman es algo "absolutamente transcendental" y de suma importancia.

Javier Seguí afirma que no siempre hay una razón para que determinada imagen se fije en la memoria. Simplemente "una imagen que te conmueve tanto, o te excita tanto, o te llena tanto, de repente es parte de ti". ${ }^{51}$

Según la ideología asociacionista, cualquier imagen se forma y

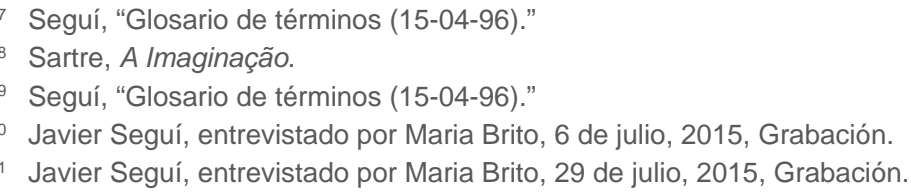


combina, mediante la ley de reintegración y contigüidad ${ }^{52}$-restauración, resurrección, evocación en que el espíritu devuelva la vida a esas percepciones adormecidas, animándolas y proyectándolas en el presente-; o según la ley de la similaridad o ley del contraste -una idea se apodera del sujeto y se convierte en término de comparación, de medida según la cual se construyen representaciones; establece semejanzas descubre analogías y las agrupa. ${ }^{53}$ Sin embargo, estas leyes estan sujetas a las deducciones del temperamento de cada uno. Cada espíritu persigue un fin distinto.

El poeta y ensayista inglés Joseph Addison aporta una pista respecto a la formación de esas imágenes - que Javier Seguí nombra "imágenes-fuerza" - al afirmar que ellas se fundan en los placeres de la imaginación originadas en la vista frente a algo "grande, singular, o bello". ${ }^{54}$ Según comenta "todo lo que es nuevo o singular da placer a la imaginación; porque llena el ánimo de una sorpresa agradable; lisonjea su curiosidad; y le da idea de cosas que antes no había poseído."55

El hastío de lo común, lo normal y lo vulgar provoca que la extrañeza de lo nuevo y singular devuelva el placer a la imaginación; sirve de "alivio a aquel tedio de que nos quejamos continuamente en nuestras ordinarias y usuales ocupaciones."

Son esas imágenes que emocionan las que, como dice Javier Seguí, avalan cada temática edificatoria y su propia trayectoria operativo-imaginal.

\footnotetext{
52 Para Spinoza “(...) la imagen es una afección del cuerpo humano; o acaso, a contigüidad, o habito son la fuente de conexión de las imágenes, y los recuerdos, la resurrección material de una afección del cuerpo provocada por caudas mecánicas" en Sartre, A Imaginação, 15.

53 Ludovic Dugas, La imaginación, trad. César Juarros (Madrid1905).

54 Joseph Addison, Los placeres de la imaginación y otros ensayos de The Spectator (Madrid: Visor Distribuiciones, 1991), 137.

55 Addison, Los placeres de la imaginación y otros ensayos de The Spectator,140.

56 Addison, Los placeres de la imaginación y otros ensayos de The Spectator,140.
} 


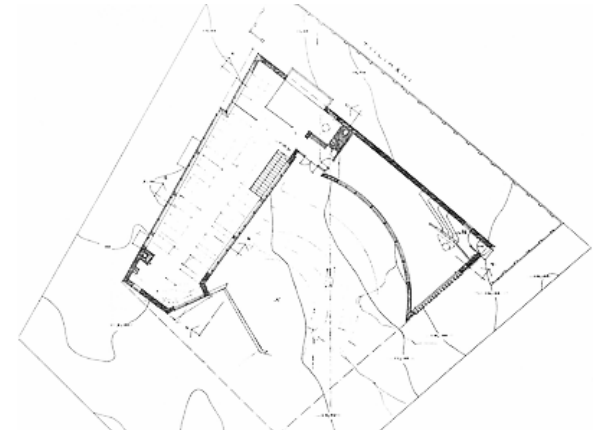

ESTUDIO, Helsinki, Finlandia, (1955). Alvar Aalto.
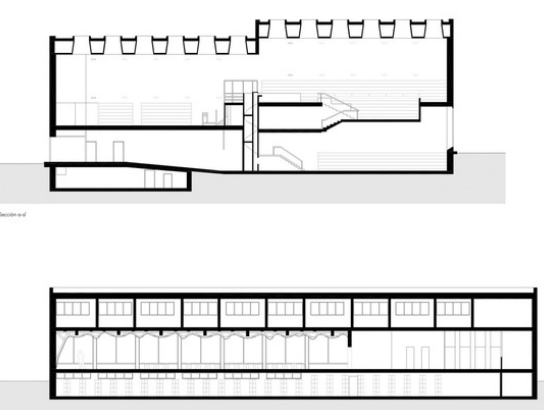

BIBLIOTECA DE VIIPURI, Vyborgi, Rusia, (1933-1935). Alvar Aalto.

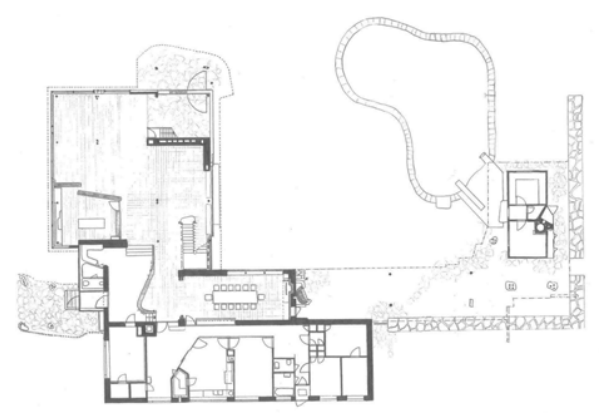

VILLA MAIREA, Noormarkku, Finlandia, (1938-1939). Alvar Aalto.

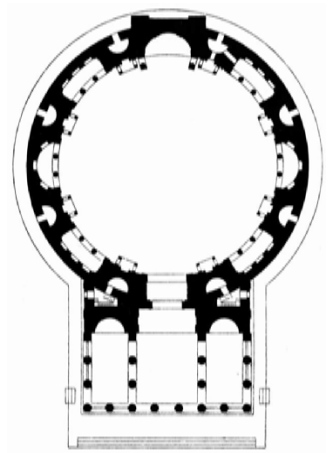

PANTEÓN, Roma, Italia(118-128).
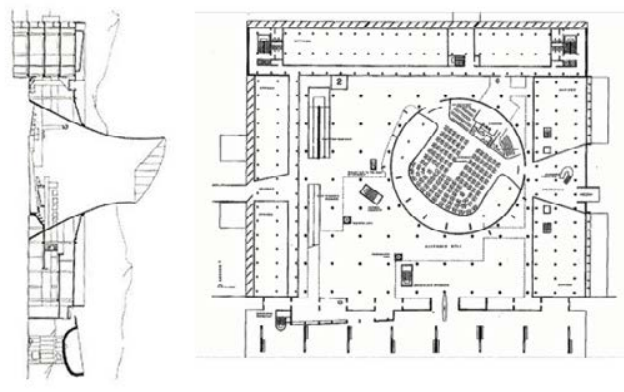

PALACIODE LA ASAMBLEA, Chandigarh, India, (1951-1965). Le Corbusier. 


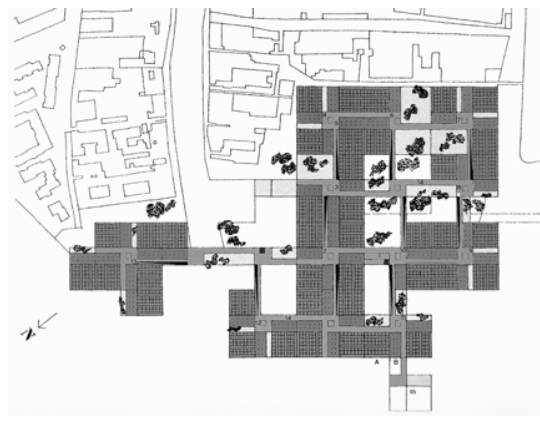

NUEVO HOSPITAL DE VENECIA, (1964). Le Corbusier.

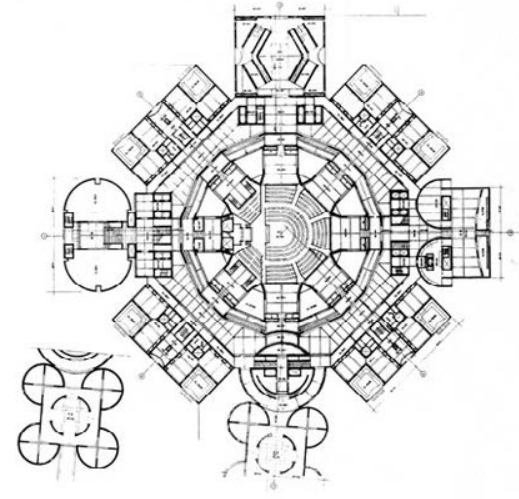

ASAMBLEA NACIONAL DE

BANGLADESH, Daca, Bangladesh, (1964-1982). Louis Kahn.

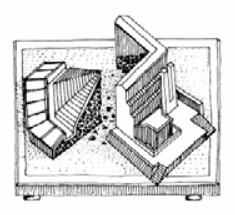

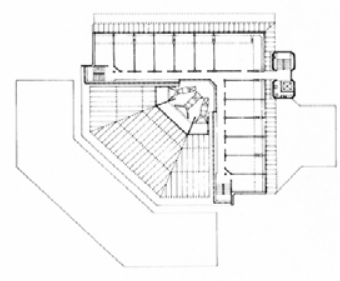

FACULTAD DE HISTORIA DE LA UNIVERSIDAD, Cambridge, Inglaterra, (1964-1968). James Stirling.

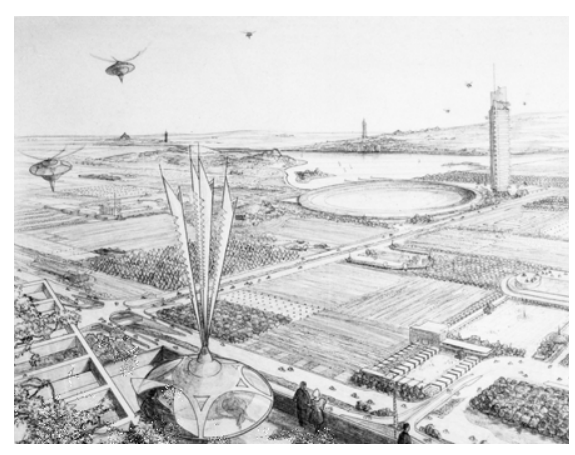

BROADACRE CITY, (1932).

Frank Lloyd Wright.

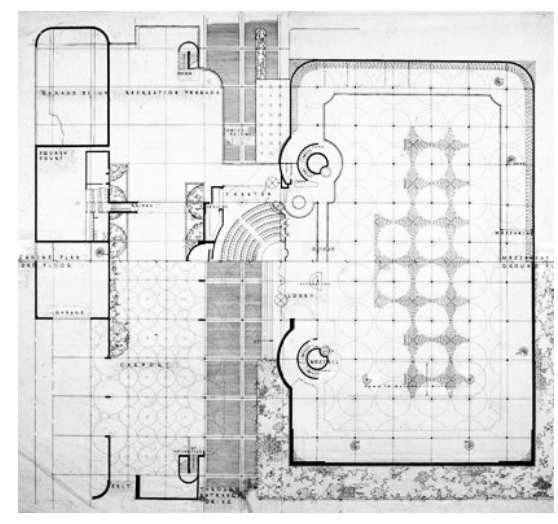

EDIFICIO JOHNSON WAX, Racine, Estados Unidos, (1936-1939), Frank Lloyd Wright.

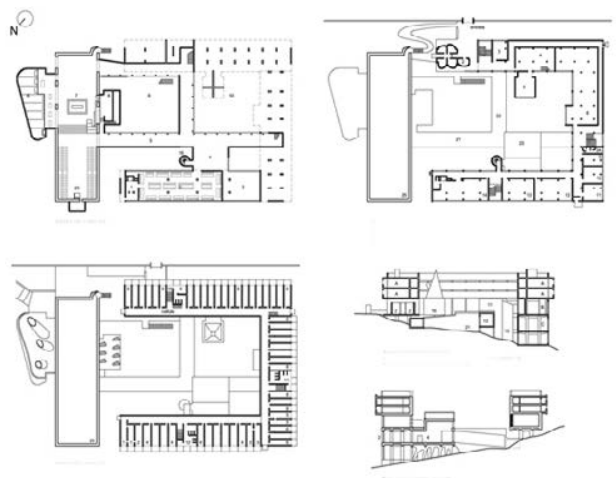

CONVENTO DE SAINTE-MARIE DE LA TOURETTE, Éveux, Francia, (1956-1960). Le Corbusier. 


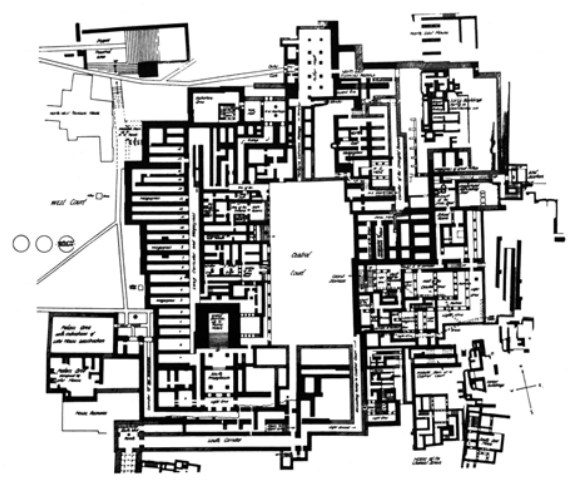

PALACIO DE KNOSSOS, Creta, Grecia, (2000 a.C).

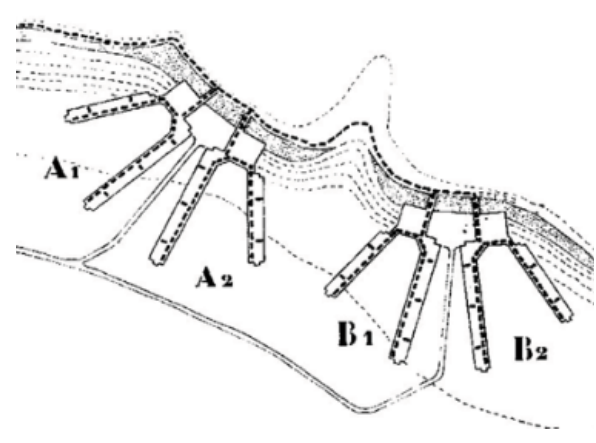

RESIDENCIA DE ESTUDIANTES en St.Andrews, Estados Unidos, (19641968). James Stirling.

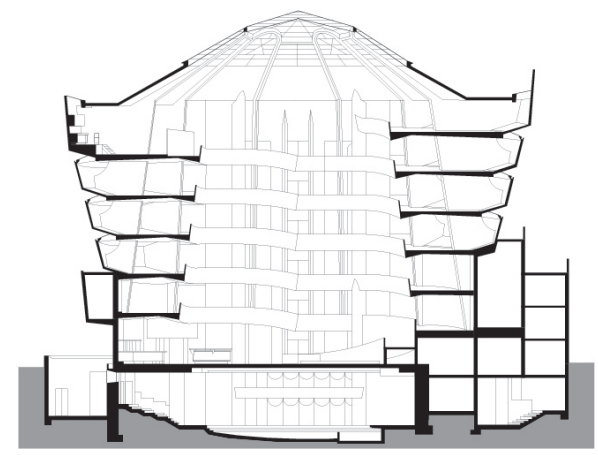

GUGGENHEIM, Nueva York, Estados Unidos,(1938). Frank Lloyd Wright.

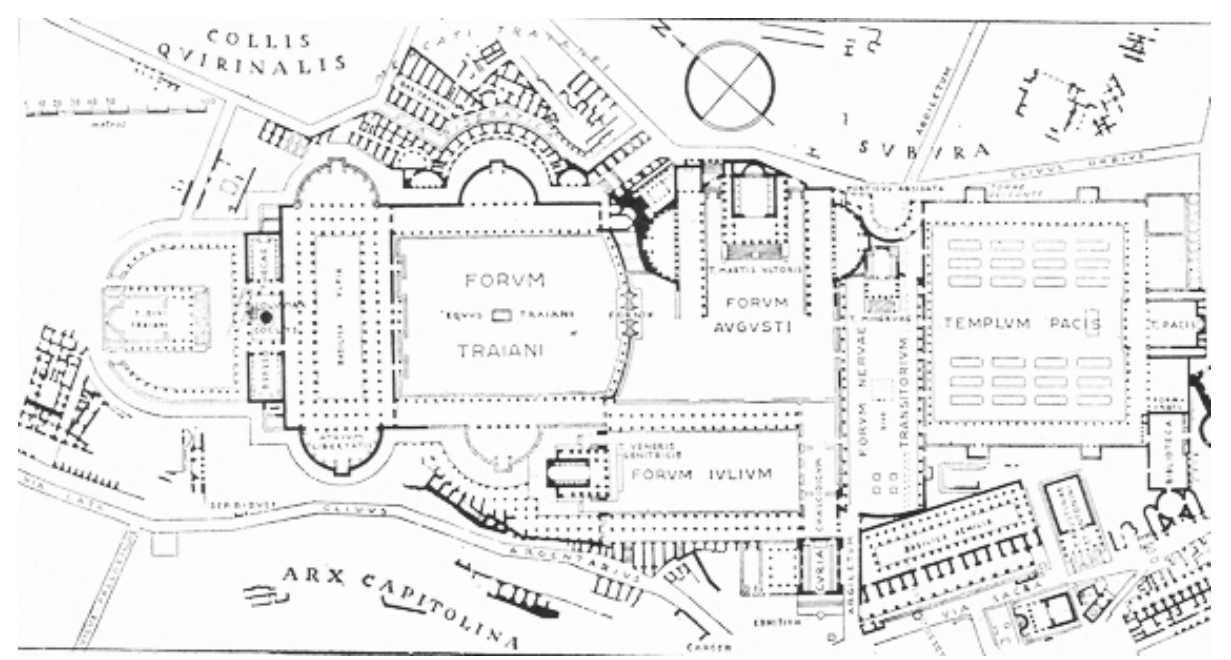

FORO ROMANO, Roma, Italia, (VI a.C.). 


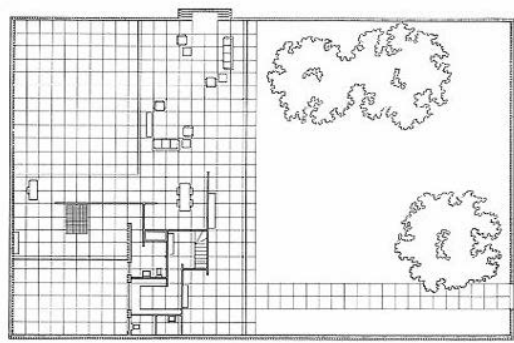

CASA CON TRES PATIOS, (1934). Mies Van der Rohe.

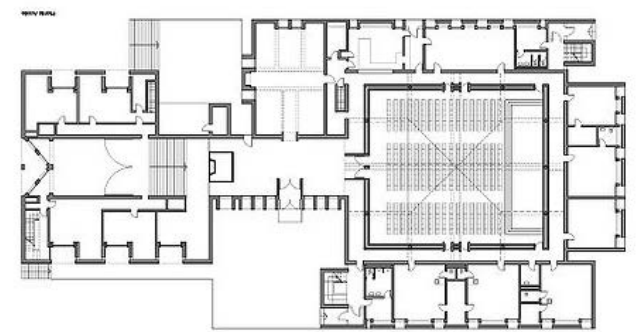

PRIMERA IGLESIA UNITARIA, Nueva York, Estados Unidos, (1959), Louis Kahn.
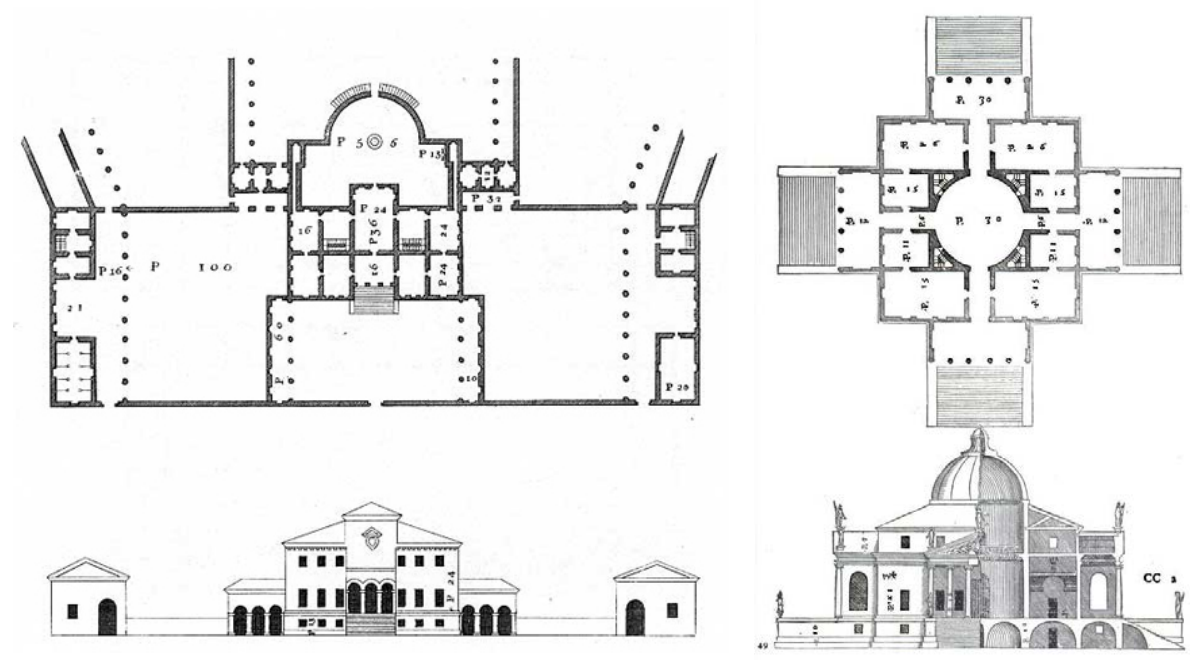

VILLA GODI MALINVERNI, Lugo di Vicenza, Italia, (1542).

VILLA CAPRA "LA ROTONDA", Vicenza, Italia, (1566). Andrea Palladio.

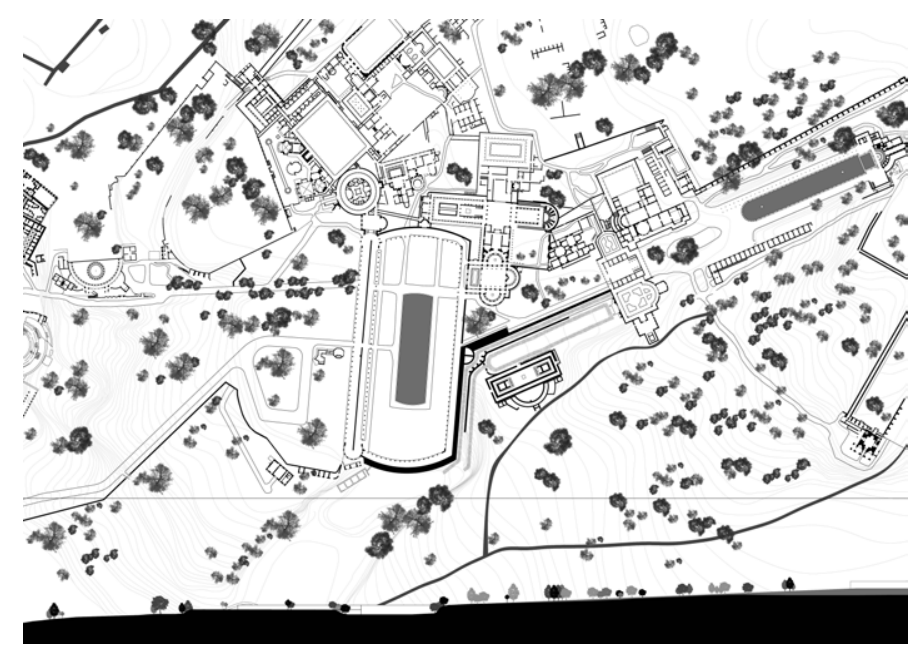

VILLA ADRIANA, Tivoli, Italia, (siglo II). 
Las "imágenes-fuerza" de Javier Seguí son de distintas épocas, pero ambas ejercen un impacto decisivo en su manera de percibir el espacio. Son imágenes clave que se van conectando en el tiempo. Seguí comenta lo difícil que es para él realizar un inventario de todas esas imágenes, habida cuenta de que muchas de ellas son simplemente situaciones o cuentos, como es el caso de Príncipe Valiente creado por Harold Foster en 1937, ambientado en la corte del Rey Arturo y la leyenda del Grial: ${ }^{57}$ "Camelot: la ciudad de la mesa redonda, donde aparecen aventuras fundamentales como la búsqueda del Grial. La ciudad de la mesa redonda: mi falansterio, mi ciudad secreta ideal. Mi radical de ciudad. De convivencia. De estar en el mundo."58

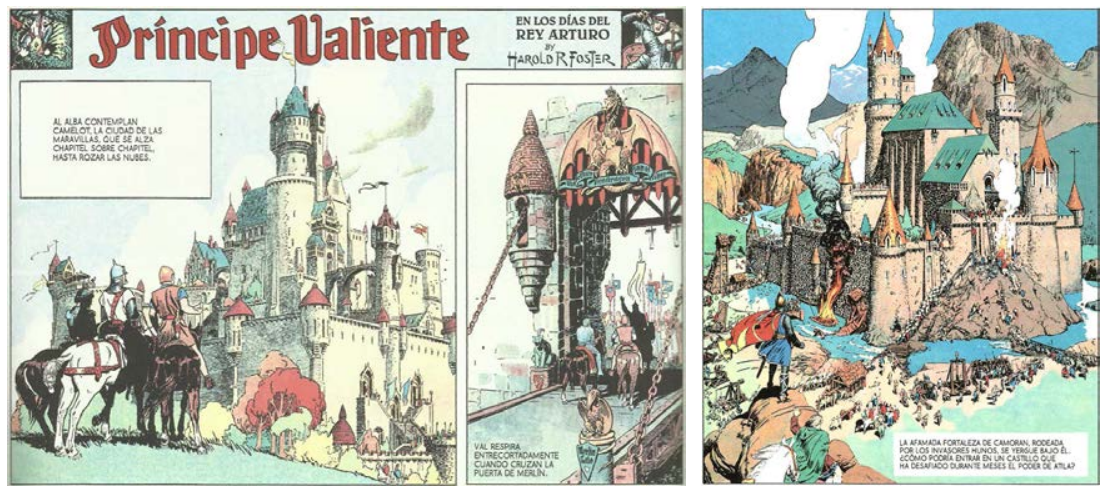

PRINCIPE VALIENTE - CAMELOT O LA FORTALEZA DE ANDELKRAG, (1939). Harold Foster. Viñeta izquierda: "Al alba contemplan Camelot, la ciudad de las maravillas, que se alza capitel sobre capitel hasta rozar las nubes." Para Javier Seguí, esta ciudad retrata un ámbito en el que la comunidad trabaja, habla, juega y "plantea operaciones colectivas". Es "un lugar fortificado en el centro de Europa, último bastión de poetas guerreros, sitiado por los hunos, que sucumbe ante las hordas bárbaras en un clima entusiasta de exaltación de la amistad y del amor entre artistas de todos los géneros, que preferían morir luchando antes que entregarse a los conquistadores" ${ }^{59}$

Según afirma que, la magia de estas imágenes-fuerza reside en el hecho de que, "descubren una parte de ti de cuya existencia no sabías nada." 60 Pero, actualmente, la imagen visual sustituye esas imágenes interiores, las únicas capaces de generar riqueza de significados.

\footnotetext{
57 Tal como confiesa Javier Seguí, la ciudad de la mesa redonda era su ciudad radical secreta. Camelot es una especie de jardín de Epicuro, de comunidad filosófica, una situación "intermedia entre las moradas interiores y la perfección exterior radical". Camelot representa la fantasía, la imagen ideal, la "arquitectonicidad dialogante, una pasión vacía de un contenedor de vida plena fluyente". Este cómic, que plantea ideales de caballería, nobleza, lealtad y justicia, habla de unos valores que Javier Seguí desea rescatar: comunas abiertas, no elitistas, donde el estudio y la práctica de las artes son el vehículo para alcanzar la libertad.

58 Javier Seguí, entrevistado por Maria Brito, 23 de junio, 2015, Grabación.

59 Seguí, «Camelot (2) (10/07/2010),» (Madrid: Instituto Juan Herrera de la Escuela de Arquitectura de Madrid, 2010).
}

60 Seguí, 29 de julio, 2015 
Heidegger dice que "la imagen del mundo no pasa de ser medieval a ser moderna, sino que es el propio hecho de que el mundo pueda convertirse en imagen lo que caracteriza la esencia de la Edad Moderna." ${ }^{61}$ Es decir, la conquista del mundo como una imagen es el gran acontecimiento de la Edad Moderna.

Juhan Pallasmaa opina que la actual preeminencia de la visión suprime el uso de otros sentidos, transformando el mundo en un banco de datos de imágenes sin otras cualidades sensoriales. La imagen actual, "fabricada, manipulada y producida en serie", crea una nueva manera de mirar el mundo, en simultáneo, desafiando tiempo y espacio y transformándose en el "único sentido lo suficientemente rápido como para seguir el ritmo del increíble incremento de la velocidad en el mundo tecnológico.”62

Para Seguí, "muchos de los aspectos canónicos del dibujo convencional tienen más que ver con el tacto que con la vista." 63 Mientras que para Aristóteles el oído es el sentido primordial, y el tacto, el fundamento de la inteligencia humana; hoy, esas imágenes auditivas y táctiles son aplastadas por las visuales que pueblan y dominan el imaginario.

En el libro Word of Sense, Classen aboga por no centrarse exclusivamente en los cinco sentidos fisiológicos conocidos. Existen otros cinco sentidos, espirituales e internos, que son en realidad los responsables de procesar toda la información que los fisiológicos envían al cerebro: memoria, instinto, imaginación, fantasía y sentido común. Estas facultades sensoriales y mentales son absolutamente necesarias para aprehender la realidad y construir imágenes. ${ }^{64}$ Algunos científicos defienden, incluso, que los humanos están dotados de una especie de "sentido magnético" que, como a las palomas o a los murciélagos, permite la orientación en relación al campo magnético terrestre.

En la sociedad actual, la producción y renovación compulsiva de imágenes promueve una busqueda esquizofrénica y constante de nuevas formas. ${ }^{65}$

\footnotetext{
61 Martin Heidegger, "La época de la imagen del mundo," en Caminos de bosque (Madrid: Alianza, 1995), 89.

62 Juhani Pallasmaa, Los ojos de la piel, trad. Moisés Puente (Barcelona: Editorial Gustavo Gil, 2006), 20-21.

63 Javier Seguí, Dibujar, proyectar (IV) - Acerca de algunas incongruencias en la enseñanza del dibujo y del proyecto arquitectónico (Madrid: Instituto Juan de Herrera de la Escuela Técnica Superior de Arquitectura de Madrid, 2003).

64 Constance Classen, "Worlds of Sense: Exploring the Senses in History " The Canadian Journal of Sociology Vol. 21, No. 2 (1996).

65 Morales, Arquitectónica. Sobre la idea y el sentido de la arquitectura.
} 
Conozco bien estos autosuficientes discursos sobre la magnífica realidad. Pero lo que llamáis así no es más que una combinación de dos irrealidades: una fachada respetable que ayuda a tranquilizar la consciencia de los poderosos y los triunfadores, y un submundo de sueños y cosas prohibidas que permanecen fuera de lo visible. ${ }^{66}$

Tras las imágenes se esconden las sorpresas más placenteras y todo lo que todavía queda por descubrir. Ellas pueblan el imaginario y, como dice Gilbert Durand, son "el capital pensado del homo sapiens", ${ }^{67}$ el gran erario de la humanidad.

El último descubrimiento de Javier Seguí, es la "gran imagen sin forma" 68 que hace referencia a todo lo que pasa en el interior del ser humano y no tiene forma. Es la propia emoción fusionada con el movimiento del cuerpo. ${ }^{69} \mathrm{La}$ "gran imagen sin forma" no es lo que se ve o lo que se siente, sino la propia vida; ese impulso que sale del cuerpo y genera energía y acción. Jean-Luc Nancy dice, incluso, que "el cuerpo ex-cribe, traza y busca encontrar en este "habla" este lenguaje mudo, sentido". ${ }^{70}$

\footnotetext{
66 Peter Sloterdijk, El árbol mágico. El nacimiento del psicoanálisis en el año 1785. Ensayo épico sobre la filosofía de la psicología, trad. Ana $\mathrm{M}^{\mathrm{a}}$ de la Fuente (Barcelona: Editorial Seix Barral, 1986), 123.

67 Gilbert Durand, Les Structures Anthropologiques De L'imaginaire (Paris: Dunod, 1984).

${ }^{68}$ Relacionado con la propuesta de Françoise Jullien en su libro La gran imagen no tiene forma.

69 Javier Seguí, entrevistado por Maria Brito, 2 de junio, 2014, Grabación.

70 Seguí, Dibujar, proyectar (LVIII) - El imaginario del dibujar, 25.
} 


\section{3 imaginario}

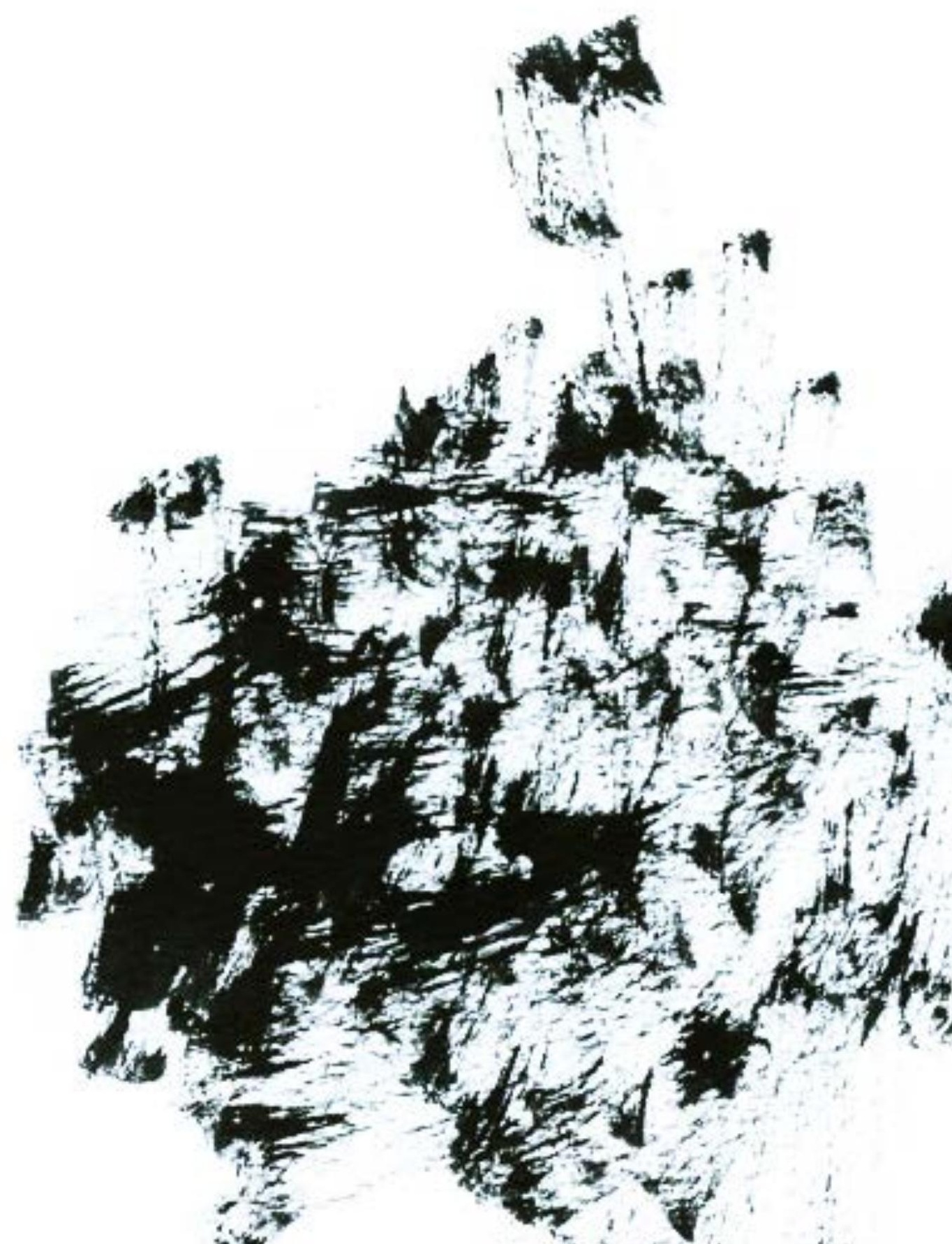


(...) el imaginario no existe; no hay ningún imaginario ahí fuera esperando ser descubierto o comprendido. Como los tipos ideales weberianos, el imaginario sólo está, como concepto o herramienta, en la mente de quien lo postula y lo usa como categoría de análisis. ${ }^{71}$

El concepto del imaginario, como lo entiende Carl Jung, es una especie de depósito de las reminiscencias del alma, un "museo de todas las imágenes pasadas, posibles, producidas y a producir". ${ }^{72}$ Según Hamann, el imaginario es "el tesoro del conocimiento y de la felicidad humanas". ${ }^{73}$

Imaginario.- Que sólo existe en la imaginación; decíase del estatuario o pintor de imágenes (sic).

En sociología se emplea el término imaginario (individual o social) para designar el depósito icónico e ideal (también llamado idolomórfico) de una persona, una sociedad, o un grupo social. ${ }^{74}$

Emmanuel Lizcano contempla que el imaginario es indefinido, sencillamente porque es la "fuente de las definiciones"; 75 forma y conforma el mundo habitado, que en realidad es una construcción de metáforas compartida por todos; el imaginario se edifica a partir de dos tensiones importantes: el deseo de utopía y el conjunto de creencias y prejuicios propios de las tradiciones y los hábitos comunes. Corroborando las palabras de Castoriadis, él dice que el imaginario es "denso por todas partes" siendo el motor de la creatividad social, pero también su barrera, lugar del prejuicio y de las presuposiciones - por ello dominar el imaginario del ser humano es dominar su propia libertad.

El imaginario es, sobre todo, un espacio que permite ensayar, anticipar y controlar nuestras actuaciones, evitando los impulsos producidos por las constantes amputaciones de los instintos y deseos. Psicólogos y psicoanalistas afirman que sin ese lugar donde la reflexión controla y contiene al delirio, el ser humano estaría condenado a la locura.

A comienzos del siglo XX, surge una disciplina en la teoría del imaginario: el Psicoanálisis, representado por su máximo guía,

\footnotetext{
${ }^{71}$ Emmanuel Lizcano, Metáforas Que Nos Piensan. Sobre Ciencia, Democracia Y Otras Poderosas Ficciones (Madrid: Ediciones Bajo Cero, 2006), 60.

72 Durand, L'imaginaire. Essai Sur Les Sciences Et La Philosophie De L'image, 3.

73 Galvano della Volpe, Historia del gusto, trad. Z. Gonzáles Péres (Madrid: Visor, 1972), 70.

74 Seguí, "Glosario De Términos (15-04-96)."

75 Lizcano, Metáforas que nos piensan. Sobre ciencia, democracia y otras poderosas ficciones.
} 
Sigmund Freud, quien descubre que el inconsciente opera, a través de la imaginación, en el consciente. A este concepto, Carl-Gustav Jung añade la noción de "inconsciente colectivo"76, núcleo de concentración místico-simbólica, arcaico, innato y heredado. ${ }^{77}$

Cuando el imaginario es compartido y aceptado por un grupo de personas se habla de "imaginario social", ${ }^{78}$ tal como lo define su creador Cornelius Castotiadis. Para el filósofo, el imaginario social es, al igual que la ideología, la convención colectiva según la cual se utilizan las palabras, "significados aceptados e incuestionables"79 y las operaciones con un determinado sentido compartido; una reducción del sentido general de las cosas en función de los intereses de un grupo. ${ }^{80}$ Para Javier Seguí se trata de algo "muy importante, porque tiene que ver con la visión colectiva de cómo se puede derivar una cosa y de cómo una situación puede transmutarse." 81

Los imaginarios sociales corresponden a grupos con intereses e idiolectos comunes que todos puedan manejar; construcciones de la sociedad que dicen cómo hay que ver, entender y valorar.

La institución histórico-social es aquello en y por lo cual se manifiesta y es lo imaginario social. Esta institución es institución de un magma de significaciones, las significaciones imaginarias sociales. El sostén representativo participable de esas significaciones -al cual, bien mirado, no se reducen, y que puede ser directo o indirecto- consiste en imágenes o figuras, en el sentido más amplio del término: fonemas, palabras, billetes de banco, geniecillos, estatuas, iglesias, utensilios, uniformes, pinturas corporales, cifras, puestos fronterizos, centauros, sotanas, lictores, partituras musicales. Pero también en la totalidad de lo percibido natural, nombrado o nombrable por la sociedad considerada. Las composiciones de imágenes o figuras pueden a su vez, ser, y a menudo son,

\footnotetext{
76 En torno a su pensamiento surge en 1933 (y se prolonga hasta 1988) el Circulo de Eranos (en griego, comida de la fraternidad), un grupo social que se reune anualmente en Ascona (Suiza) analizando los lazos entre racional e irracional, religión y ciencia, retomando los concepto Unus Mundus y complexo oppoitorum de Jung y en los que participan Rudolf Otto, Mircea Eliade, Joseph Campbell, Herbert Read, Henry Corbin, Gershom Scholem, Erich Neumann y James Hillman .

77 Marta Herrero Gil, "Introducción a las teorías del imaginario. Entre la ciencia y la mística," Revista de Ciencias de las Religiones 13 (2008): 244.

78 Cornelius Castoriadis, La institución imaginaria de la sociedad, trad. Antoni Vicens y Marco-Aurelio Galmarini, vol. 1 (Buenos Aires: Tusquets Editores, 1993).

79 Daniel Cabrera, "Imaginario social, comunicación e identidad colectiva," 2004, 16 de octubre de 2015: http://www.portalcomunicacion.com/dialeg/paper/pdf/143_cabrera.pdf. 80 Cornelius Castoriadis, La institución imaginaria de la sociedad trad. Marco-Aurelio Galmarini, vol. 2 (Barcelona: Tusquets Editores, 1989).

81 Seguí, 4 de marzo, 2014
} 
imágenes o figuras, y, por tanto, también soportes de significación. Lo imaginario social es, primordialmente, creación de significaciones y creación de imágenes o figuras que son su soporte. La relación entre la significación y sus soportes (imágenes o figuras) es el único sentido preciso que se puede atribuir al término "simbólico. ${ }^{82}$

El imaginario está antes que las imágenes, haciendo posibles unas e imposibles otras. El imaginario educa la mirada, una mirada que no mira nunca directamente las cosas: las mira a través de las configuraciones imaginarias en las que el ojo se alimenta. (...) El imaginario en que cada uno habitamos, el imaginario que nos habita, nos obstruye así ciertas percepciones, nos hurta ciertos caminos, pero también pone gratuitamente a nuestra disposición toda su potencia, todos los modos de poder ser de los que él está preñado. ${ }^{83}$

Paul Ricœur funda el origen del imaginario colectivo en la base de la ideología y de las utopías. Mientras que la ideología se vincula a la necesidad de un grupo de adquirir una imagen de sí mismo, de ponerse en escena, la utopía es en realidad un género literario declarado, un proyecto imaginario de otra sociedad, un salto a "ningún lugar", un más allá de lo real, el sueño, los esquemas perfeccionistas. En este juego del imaginario social puede entenderse la ideología como integradora y la utopía como subversiva. ${ }^{84}$

Ricœur atribuye a cada una de ellas - ideología y utopía - una disfunción: a la disfunción de la ideología la llama distorsión y disimulo; y a la disfunción de la utopía le llama esquizofrenia. Para curar estas disfunciones propone una mirada desde ese "ningún lugar". ${ }^{85}$

Sobre este discurso, Javier Seguí alerta que, sin embargo, ese "ningún lugar" (u-topos) no debe ser confundido con no-lugar, en tanto que éste es un ámbito inestable, del movimiento, de lo no referible, mientras que "ningún lugar" es la interioridad oída desde fuera. "Ningún lugar" es la matriz del aventurar configurante que, apoyado en la extrañeza, permite la poética autoconstituyente; es la propia imaginación disolvente-diagramante que borra y juega desarrollando el significar. ${ }^{86}$

Según Seguí, el imaginario social es exactamente ese vínculo

\footnotetext{
z Castoriadis, La institución imaginaria de la sociedad 2, 122.

83 Lizcano, Metáforas que nos piensan. Sobre ciencia, democracia y otras poderosas ficciones, 42-43.

84 Ricœur, Del texto a la acción.

85 Ricœur, Del texto a la acción, 217.

86 Seguí, "La imaginación (1) (31/07/10)."
} 
analógico que convierte "el otro" en "mi semejante" a través de la utopía -generalmente asociadas al género literario, son el salto hacia otro lugar, hacía ningún lugar; errancia- y de la ideología -integración y reflejo- que "cubre la distancia entre la demanda, que proviene de arriba, y la creencia, que proviene de abajo." ${ }^{87}$ Es decir, la mediación del vínculo social simbolizado, una especie de consciencia colectiva.

Pero ¿no podrán esas utopías errantes ser algún día "integración y reflejo"? Las utopías visionarias del escritor clásico francés Julio Verne o de las del propio marqués de Pombal ${ }^{88}$ son consideradas fantasías dementes e ilógicas, convertidas, años más tarde, en realidades absolutamente exitosas.

Al marqués de Pombal, considerado el precursor de la sismología occidental moderna, el primero que habla de réplicas y del comportamiento animal antes y durante un terremoto, también se le tiene en su momento por un excéntrico y utópico. En 1755, año en que un terremoto incendia y destruye prácticamente por completo Lisboa, el visionario del urbanismo permite la recuperación y la reconstrucción de toda la ciudad. Su vasta y quimérica propuesta incluye grandes calles rectilíneas y amplias avenidas. A este respecto, cuando alguien le pregunta qué necesidad hay de tener calles tan anchas, el marques contesta: "un día serán pequeñas" 89 , conjetura que el actual tráfico lisboeta pone de manifiesto.

Es un hecho que la ciencia y la técnica (...) engendran lite ratura de lo maravilloso. Sin embargo, no basta con que el escritor se contente con extrapolar los éxitos, ya que la realidad rápidamente da alcance a la anticipación. Para no hablar sino de relatos de un maestro del género, pero para quien el fenómeno se ha producido ya, quiero decir Julio Verne, la invención del submarino vuelve caduco a Matias Sandorf y Veinte mil leguas de viaje submarino; la del avión, Robur el conquistador; la del cohete espacial, De la Tierra a la Luna, la de la televisión, El castillo de los Cárpatos. ${ }^{90}$

Si es verdad que el imaginario social se funda en la ideología y la utopía, no es menos cierto que, tal como mantiene Seguí, se revela en los "mitos incrustados", en las "formas de entender las cosas" que se reciben de otros y en la manera de percibir las metáforas que descifran el entorno.

87 Seguí, "La imaginación (1) (31/07/10)."

88 Sebastião de Carvalho e Melo, noble, diplomático y estadista portugués.

89 José Ma Pascual, "Comentario: Texto Del S. XVIII," iculture,2015, 10 de junio de 2015: http://iculture.es/comentario-texto-del-s-xviii/.

90 Roger Callois, Imágenes, imágenes... (Sobre los poderes de la imaginación). trad. Néstor Sánchez (Buenos Aires: Editorial Sudamerica, 1970), 32. 
Por ejemplo, en esta escuela, el empleo de ciertos términos es completamente mitológico, ideológico. Las palabras que se dicen en esta escuela, los conceptos, en muchas escuelas de arquitectura... Los gremios fabrican su propio idiolecto, que conecta con el mundo de una manera delirante. ${ }^{91}$

A lo largo de la Historia son innumerables las represiones políticas como forma de moderación y control del imaginario. Quienes ostentan el poder son conscientes de que el dominio y el control de las masas se consigue controlando y creando mitos, manipulando y dominando las metáforas. Es la forma más eficaz de apropiarse y vigilar el imaginario, garantizando el control de las sociedades.

Las restricciones sociales para la representación del sexo son, a nuestro juicio, secundarias: se trata de una consecuencia de la adhesión a un credo determinado que justifica y naturaliza el dominio de una clase y la opresión de la que otra es víctima. El decoro en el teatro franquista consiste, precisamente, en representarse como alguien con una historia y con un derecho al poder. ${ }^{92}$

Por este motivo, los mitos y metáforas aceptadas por las masas hacen del imaginario un inventario de prejuicios y significados instituidos por una visión colectiva distorsionada.

(...) tensión entre la capacidad instituyente que tiene toda colectividad y la precipitación de esa capacidad en sus formas instituidas, congeladas. Esa doble dimensión, instituyente e instituida, de toda formación colectiva asegura, respectivamente, tanto la capacidad autoorganizativa del común como su posibilidad de permanencia, tanto su aptitud para crear formas nuevas como su disposición para recrearse en sí misma y afirmarse en lo que es. ${ }^{93}$

(...) esos sorprendentes duendes del imaginario que nos habitan en secreto. Conservadlas, y conservareis el mundo. Cambiadlas, y cambiareis el mundo. ${ }^{94}$

Sobre esos aparatos que las sociedades determinan como herramientas de verificación de la verdad, Foucault dice:

\footnotetext{
91 Javier Seguí, entrevistado por Maria Brito, 16 de septiembre, 2014, Grabación.

92 Alberto Mira Nouselles, "Realismo Clásico: ¿Grado Cero De La Representación?," en De silencios y espejos - Hacia una estética del teatro español contemporáneo (Valencia: Universitat de Valencia, 1996, 1996), 129.

93 Lizcano, Metáforas que nos piensan. Sobre ciencia, democracia y otras poderosas ficciones, 55.

94 Lizcano, Metáforas que nos piensan. Sobre ciencia, democracia y otras poderosas ficciones, 71.
} 
Lo importante de tales cambios no es que sean rápidos o de gran alcance, o mejor dicho, esta rapidez y este alcance no son más que signos de otras cosas: una modificación en las reglas de formación de los enunciados que son aceptados como científicamente verdaderos. No se trata pues, de un cambio de contenido, ni tampoco de una alteración de la forma teórica; lo que está en cuestión es lo que rige los enunciados y el modo como se rigen unos y otros para constituir un conjunto de proposiciones aceptables científicamente y susceptibles por consiguiente de ser verificadas e invalidadas por procedimientos científicos. ${ }^{95}$

La metáfora es, por definición, una figura literaria, pero también de transmisión oral. Neurológicamente se puede decir, incluso, que es anterior al lenguaje porque su origen se sitúa en la percepción de la imagen recibida por impulsos nerviosos, que sólo después se transforma en lenguaje.

(...) no son conceptos, ideas o imágenes las que lo pueblan; lo imaginario no sabe de identidades, de esos contornos definidos, de-terminados, que caracterizan a todo concepto, imagen o idea. El imaginario es el lugar de donde estas representaciones emergen, donde se encuentran pre-tensadas. Esa pre-tensión es la que se manifiesta en la metáfora. ${ }^{96}$

Al consultar el diccionario, se descubre una definición bastante sintética y precisa de su concepto:

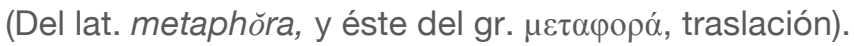

1. f. Ret. Tropo que consiste en trasladar el sentido recto de las voces a otro figurado, en virtud de una comparación tácita. $^{97}$

La metáfora es una herramienta indispensable para el imaginario, no por su resultado final y su cualidad poética, sino como elemento dinámico de conocimiento capaz de transportar el significado entre distintos significantes. La metáfora desvela lo que suele quedar oculto entre las conexiones más distantes y descubre la similitud de cada significado; se mueve entre lo inconsciente y lo consciente, lo ficticio y lo real. Sartre añade: "si las palabras son metáforas, que nos hagan comprender la realidad que se oculta bajo las palabras." 98

\footnotetext{
95 Michel Foucault, Un diálogo sobre el poder y otras conversaciones, trad. Miguel Morey (Madrid: Alianza Editorial, 2000), 131.

96 Lizcano, Metáforas que nos piensan. Sobre ciencia, democracia y otras poderosas ficciones, 62.

97 Real Academia Española, "Metáfora," 1 de julio de 2015: http://lema.rae.es/drae/srv/ search?id=ONHtV8vf3DXX2FCwKLog.

98 Sartre, A Imaginação, 137.
} 
La metáfora es así al imaginario colectivo lo que el lapsus o el síntoma es al inconsciente o al imaginario de cada cual. Mediante ella sale a luz lo no dicho del decir, lo no sabido del saber: su anclaje imaginario. Caer en que un lapsus es un lapsus, en que una metáfora es una metáfora, es empezar a caer por el hueco que lleva al imaginario.99

La primera y más conocida metáfora es la de la Caverna, que Platón menciona en el VII libro de La República, en el siglo VI a.C. En esa metáfora el filósofo asocia la imaginación a las sombras fantasmagóricas como grado inferior del conocimiento y a la luz para referirse a la razón, al conocimiento.

Platón usó con frecuencia la metáfora o, mejor dicho, el lenguaje figurado, sin precisar mucho en qué consistía: a veces se trataba de una imagen, a veces, del hecho de comparar (...) Parece evidente, sin embargo, que Platón no consideraba la metáfora -y el lenguaje figurado en general- como un procedimiento ilegítimo para la exposición del saber filosófico. ${ }^{100}$

Aristóteles ya dice que "metaforizar bien (...) es percibir lo semejante", ya que lo semejante es la interpretación de lo predicativo. ${ }^{101}$

El mérito más grande es, con mucho, ser un maestro de la metáfora. Es el único arte que no se podría aprender de los demás; es también la marca de un genio original. Ya que una verdadera metáfora supone la percepción intuitiva de la similitud en las cosas disímiles. ${ }^{102}$

A excepción de Schopenhauer, los filósofos de la época moderna no conceden mucha importancia a la metáfora, negando sin más su uso en el ámbito filosófico. En el siglo XX la metáfora se considera "perteneciente al lenguaje emotivo, el cual no enuncia nada acerca de lo real". ${ }^{103}$

Bergson las considera apenas apropiadas para el mundo espiritual, ya que su función trata de sugerir y no de describir o representar. W. M. Urban, al igual que Martin Foss, afirma que son "forma de expresión que alcanza una región distinta de la descrita por una imagen y el símbolo". ${ }^{104}$ Para Ortega y Gasset, "la metáfora es un instrumento mental imprescindible, es una for-

\footnotetext{
99 Lizcano, Metáforas que nos piensan. Sobre ciencia, democracia y otras poderosas ficciones, 67.

100 Mora, Diccionario de filosofia, 189.

101 Ricœur, Del texto a la acción.

102 Callois, Imágenes, imágenes... (Sobre los poderes de la imaginación). 89.

103 Mora, Diccionario de filosofia, 190.

104 Mora, Diccionario de filosofia, 191.
} 
ma de pensamiento científico". ${ }^{105}$ Para Javier Seguí, metaforizar es justamente aprovechar la capacidad imaginaria que conecta las cosas de una manera analógica, significar lo de-significante, pero, sobre todo, es "la medida de la dimensión de la extrañeza". 106

(...) no sólo necesitamos la metáfora para hacer comprensible, mediante un nombre, a los demás, nuestro pensamiento, sino que la necesitamos inevitablemente para pensar nosotros mismos ciertos objetos difíciles. Además de ser un medio de expresión, es la metáfora un medio esencial de intelección. Hay pensamientos que se gestan y se gestionan a través de la metáfora; hay metáforas que desencadenan proyectos; hay análisis arquitectónicos que se apoyan en la propuesta metafórica. ${ }^{107}$

En palabras de Arnold Modell, las metáforas son "herramientas cognitivas que pueden operar inconscientemente". ${ }^{108}$ A juicio de Pallasmaa, las metáforas son las imágenes del lenguaje. Gracias a ellas, la arquitectura siempre ha podido combinar realidad y cultura en su mensaje.

La psicología académica apenas trata del tema de la imagen poética, que a menudo se confunde con una simple metáfora. (...) En la psicologización, la imagen lo es todo excepto un producto directo de la imaginación... Propongo, por el contrario, considerar la imaginación como una potencia importante en la naturaleza humana. ${ }^{109}$

Las metáforas son utensilios que permiten desvelar los imaginarios. Según Lizcano, están absolutamente "enraizadas" en la cultura, congeladas en el tiempo y construyen un mundo que se da por sentado. Son las que, en opinión de Javier Seguí, permiten "vincular imaginación con cierto uso del lenguaje". ${ }^{110}$

A este respecto Paul Ricœur coincide al decir que el uso de la metáfora en el discurso vincula la imaginación, no a la percepción, sino al uso del lenguaje. Como indica, la metáfora hay que verla como algo mucho mayor que un apartado de denominaciones, como un "desvío de los predicados dentro del marco de la oración entera." 111 Seguí dice "Metáfora es transporte, es la

\footnotetext{
105 Mora, Diccionario de filosofia, 191.

106 Seguí, "Encuentros. Comentarios, reducciones, anotaciones, conversaciones."

107 José Ortega y Gasset, Ensayos escogidos (Las dos grandes metáforas) (Madrid:

Taurus, 1997), 78.

108 Juhani Pallasmaa, The Embodied Image: Imagination and Imagery Architecture.

(Chichester: Wiley \& Sons Publishers, 2011).

109 Pallasmaa, The Embodied Image: Imagination and Imagery Architecture.

110 Seguí, "La imaginación (1) (31/07/10)."

111 Ricœur, Del texto a la acción, 201.
} 
definición imaginaria por antonomasia. Es decir una cosa y de repente estar diciendo otra. Eso que se llama imaginación analógica. Me acuerdo de una película maravillosa que se llama El cartero y Pablo Neruda, donde Neruda explicaba al cartero que la poesía son metáforas." 112

-¿Don Pablo?

- ¿Te quedas ahí parado como un poste?

- ¿Clavado como una lanza?

-No, quieto como torre de ajedrez.

- ¿Más tranquilo que gato de porcelana?

-Mario Jiménez, aparte de Odas elementales tengo libros mucho mejores. Es indigno que me sometas a todo tipo de comparaciones y metáforas.

- ¿Don Pablo?

-¡Metáforas, hombre!

-¿Qué son esas cosas?

-Para aclarártelo más o menos imprecisamente, son modos de decir una cosa comparándola con otra.

-Déme un ejemplo.

-Bueno, cuando tú dices que el cielo está llorando. ¿Qué es lo que quieres decir?

-¡Qué fácil! Que está lloviendo, pu’.

-Bueno, eso es una metáfora.

-Y, ¿por qué, si es una cosa tan fácil, se llama tan complicado?

-Porque los nombres no tienen nada que ver con la simplicidad o complicidad de las cosas. Según tu teoría, una cosa chica que vuela no debiera tener un nombre tan largo como mariposa. Piensa que elefante tiene la misma cantidad de letras que mariposa y es mucho más grande y no vuela -concluyó Neruda exhausto. ${ }^{113}$

En ese sentido, se puede decir que la imagen artística es, de alguna manera, una metáfora, una evocación hecha a través de asociaciones emocionales.

Las metáforas son el puente entre el artista y lo indecible, una analogía poética recurrente no sólo en la literatura, sino en todos los ámbitos artísticos. Viven en el ser humano y hacen ver con sus ojos, sentir por sus sensaciones, idear con sus ideas, imaginar entre sí y con otras, y bloquear la aparición de otras.

El grado cero de la metáfora s e daría en el hecho mismo de nombrar (...) Las etiquetas ordenan el mundo; o mejor, hacen de un caos, un mundo. Por eso, etiquetar, nombrar, es crear. Y por eso también, conseguir alterar las etiquetas, re-etiquetar las cosas o los acontecimientos, es destruir un mundo y 
hacer otro, es hacer de un terrorista un resistente o, de un excluido, un oprimido." 114

El mito, como las metáforas, forma parte del envoltorio y la formación del imaginario colectivo. Se puede decir que "toda metáfora es un pequeño mito" 115 y su procedimiento es "repetir (sincronicidad) las conexiones simbólicas que lo constituyen". ${ }^{116}$ Ellos "revelan un tejido trans-histórico por detrás de todas las manifestaciones de la religiosidad."117

Se ha dicho, por ello, que la metáfora tiene en los diálogos platónicos una función análoga a la del mito. Según Pierre Louis, el mito en Platón puede ser considerado inclusive como la coronación de la metáfora, la cual se sirve de la comparación; la metáfora estaría, pues, en un término medio entre la comparación -instrumento subalterno- y el mito -culminación de la exposición figurada. ${ }^{118}$

En el Glosario de términos (1996) de Javier Seguí se puede encontrar la siguiente definición.

Mito.- Designa fábula, ficción alegórica; relato o noticia que desfigura lo que realmente es una cosa y le da apariencia de ser más sabrosa o más atractiva; persona o cosa rodeada de extraordinaria estima (sic).

En antropología se llama mito a un relato de algo fabuloso acontecido en el pasado remoto y casi siempre impreciso. También es un mito o mitificación el convertir cosas naturales o cotidianas en mitos o acontecimientos esenciales sin aclarar sus raíces y función. ${ }^{119}$

El mito es la primera envolvencia colectiva. El sostén de la significación cultural. Lo arquitectónico más básico. ${ }^{120}$

El ser humano crea mitos porque anima todo con su ingenuidad, con la frescura de su imaginación y con miedos y deseos, voluntades y antipatías. Los mitos vienen dados por la necesidad de encontrar algo material, para fijar sus imágenes flotantes. Son representaciones sensibles necesarias hechas de sentimientos e imágenes sensoriales que los representen. Por ese motivo, la

\footnotetext{
114 Lizcano, Metáforas que nos piensan. Sobre ciencia, democracia y otras poderosas ficciones.

115 Gianbattista Vico, Princípios de uma ciencia nova, trad. Antônio Lázaro de Almeida Prado (São Paulo: Abril Cultural, 1974), 48.

116 Durand, L'imaginaire. Essai Sur Les Sciences Et La Philosophie De L'image.

117 Durand, L'imaginaire. Essai Sur Les Sciences Et La Philosophie De L'image, 56.

118 Mora, Diccionario de filosofia, 189.

119 Seguí, "Glosario de términos (15-04-96)."

120 Javier Seguí, Dibujar, proyectar (IX) - El grado cero de la arquitectura (Madrid: Instituto Juan Herrera de la Escuela de Arquitectura de Madrid, 2006), 28.
} 
imaginación, al buscar imágenes para evocar emociones emplea un lenguaje imperfecto, desfigura, materializa y particulariza los sentimientos en busca de un objeto donde descansar su significado. ${ }^{121}$ Según Bergson, el psíquico humano es muy propicio a la creación de fabulas y mundos imaginarios. ${ }^{122}$

A esta característica Castoriadis la llama "imaginación radical", entendiéndola como un cualidad que el homo symbolicus tiene para crear espontáneamente fantasmas, característica no determinada por una funcionalidad biológica ${ }^{123}$ Cuando el individuo interpreta y actúa en el seno de un grupo -sociedad- lo hace partiendo de una visión particular, pero siempre organizando su imaginario radical o instituyente.

Eduardo Pavlosky, médico, actor y dramaturgo, en su libro Espacios y creatividad dice que:

(...) cuando esa proyección es compartida nadie duda. Sólo basta un testigo -un interlocutor que diga sí- para que la creencia circule entre todos. (...) Lo importante es el convencimiento del primero. $Y$ en estos casos no me interesa tanto en lo que crees (en el objeto de tu creencia), me interesa tu convencimiento, tu forma de creer -en otras palabras, tu forma me convence. ${ }^{124}$

Cuando esas ficciones compartidas son interiorizadas, se crea el mito; una creación global, un testigo interiorizado, que circula entre todos: siempre se necesita al otro como devoto de la mística.

Según Durand, el mito es un "sistema dinámico de símbolos, arquetipos y esquemas que tienden a componerse en relato" ${ }^{125}$, cuando lo simbólico es confrontado con lo racional.

El mito, bien como las metáforas, son anclajes en el psiquismo humano encarnados en una narración, que ocupa el imaginario y que se va renovando y adaptando a las nuevas necesidades simbólicas del ser humano.

\footnotetext{
121 Dugas, La imaginación.

122 Samuel Fernández Pichel, "Mitos e imaginarios colectivos," Frame 6 (2010).

123 Cornelius Castoriadis, La institución imaginaria de la sociedad, trad. Antoni Vicens y Marco-Aurelio Galmarini, vol. 1 (Buenos Aires: Tusquets Editores, 1993).

124 Eduardo Pavlosky y Hernan Kesselman, Espacios y creatividad (Buenos Aires: Ediciones Busqueda, 1997).

125 Durand, Les Structures Anthropologiques De L'imaginaire, 53.
} 
imaginar

\section{4 el imaginario de Javier Seguí}

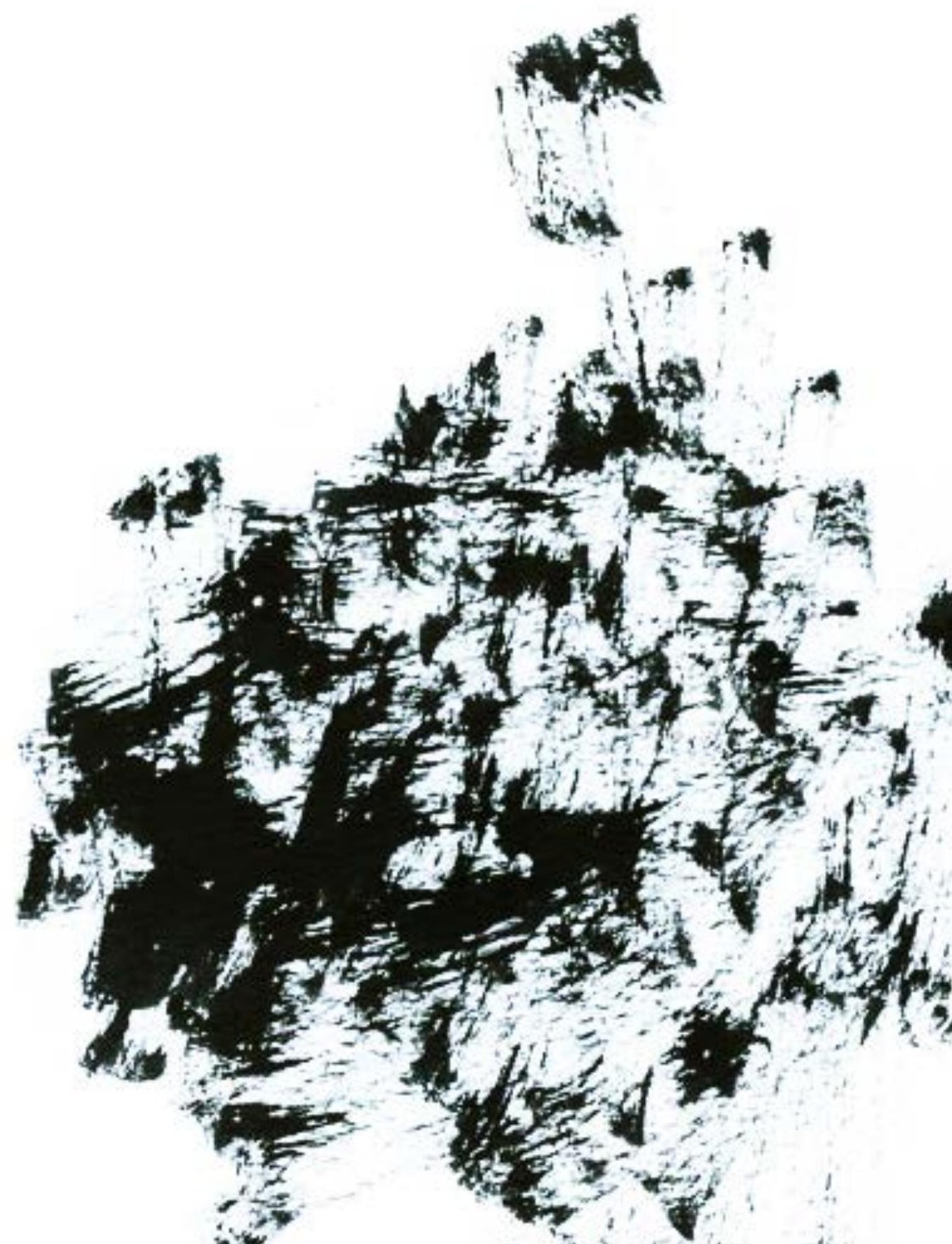


Otra cosa interesante es que parece que por fin hay gente interesada en estudiar más específicamente cuál es el imaginario de los arquitectos y el imaginario de los arquitectos de esta escuela. En este caso el campo de investigación puede ser bastante fácil: coger los enunciados de los ejercicios de proyectos, ver las cosas que la gente de proyectos manda leer, los términos que se emplean corrientemente en las conferencias, si haces ese tipo de cosas te sale el imaginario. ${ }^{126}$

Es difícil construir el imaginario de Seguí a través de sus palabras dichas o escritas, pues, como en el caso de Fernando Pessoa, su vida está repleta de sus propias invenciones, de los personajes que crea, de sus heterónimos. Como dice Juan Daniel Fullaondo, "se trata de una aventura muy densa, con cambios súbitos, tan frecuentes como inesperados, de dirección, como si hubiera vivido simultáneamente varias vidas en pleno vértigo." ${ }^{127}$

Su recorrido exige adoptar una visión multidisciplinar, un viaje por todos los campos artísticos y por diferentes culturas. Entender sus pasos implica bucear entre libros y dibujos hasta descubrir esas narraciones que, dada la densidad de su vida, ni él mismo recuerda haber creado. Perseguir el caminar apresurado de alguien que ahora, más que nunca, desea mirar atrás para asegurarse de que la huella que deja es la impronta exacta de lo que lleva haciendo toda la vida.

Seguí, obsesionado por el segundo rostro de las cosas, se desdobla en una enloquecida sucesión de intuiciones de todo orden, conferencias, publicaciones, la dirección de temas de arquitectura, seminarios, investigación, exposición, bienales, simposios... Como configurando aturdido, un ámbito espiritual abarrotado de objetos de lo más variado. ${ }^{128}$

Descodificar su imaginario significa recuperar su pasado, su ideología, sus viajes y sus libros, sus historias personales y profesionales - incluyendo tanto sus logros como sus fracasos - sus recuerdos - buenos y malos - y todos esos "valores espirituales como consecuencia de la aventura colectiva." 129

I contexto, la emoción con que se aprehende, la imaginación con que se asimila, determinan la forma de captar y retener el entorno. El cerebro, responsable de su recepción y procesamiento, muestra, cuando así se le pide, lo que asimila. El imaginario de una persona se fabrica en el cerebro, y lo que experimenta a través de los sentidos, no es más que su construcción.

\footnotetext{
126 Javier Seguí, entrevistado por Maria Brito, 4 de julio, 2014.

127 Juan Daniel Fullaondo, «Javier Segui (1964-1983),» Kain1988, 4.

128 Fullaondo, «Javier Segui (1964-1983),» Kain1988, 2.

129 Javier Seguí, Dibujar, proyectar (LXX) - Vacío, vaciar (5) (Madrid: Instituto Juan

Herrera de la Escuela de Arquitectura de Madrid, 2014), 24.
} 


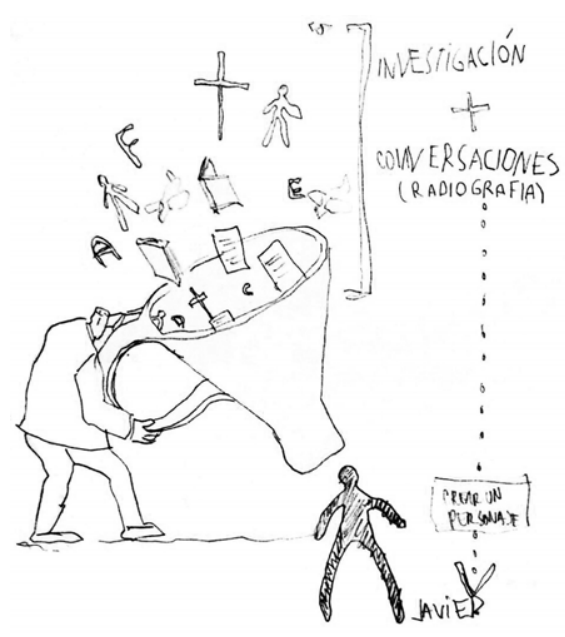

SEGUIR A SEGUÍ, (2014). Maria Brito. Dibujo representativo del proceso propuesto para descodificar el imaginario de Javier Seguí.

Por cuestión de supervivencia, el cerebro prefiere llevar a cabo esa construcción de una forma coherente, en lugar de real y por eso, algunas veces adultera o simplemete omite información. ${ }^{130}$ Lo mismo afirma Galvano Della Volpe en 1960 cuando sostiene que "las cosas imposibles, pero creíbles poéticamente son siempre preferibles a las increíbles, aunque éstas sean posibles."131

Como dice Eduard Punset, "el cerebro no está hecho para pensar, sino para sobrevivir. ${ }^{132}$ La imaginación "tiene por objeto el ideal, es decir, la realidad, no tal como es, sino como deseamos o queremos que sea." 133

El imaginario de Javier Seguí comienza a construirse dentro del marco de una familia burguesa, con buen estatus social, que le permite acceder a buenos colegios y hacer viajes que son determinantes para la configuración de su imaginario. Hijo de un padre comunista, casi anarquista, y una madre católica ortodoxa, inicia sus estudios en el colegio religioso San José, en la madrileña calle de Fuencarral, donde permanece desde los diez hasta los dieciséis años y donde su ideología empieza a tejerse.

Seguí habla de la relación que tiene con sus padres en su infancia, donde se originan sus primeros recuerdos. Su padre, contratista especializado en hormigón es, según relata, un personaje muy raro. Habla poco, y por lo general, se comunican con la mirada. Confiesa creer que su padre, Miguel Seguí, de origen vasco, es socialista radical, pues está afiliado a la CNT, un sindicato

130 Eduard Punset, "Porque nos engaña el cerebro," redes-tv.com,2004, 2004.

131 Volpe, Historia del gusto, 30.

132 Punset, "Porque nos engaña el cerebro".

133 Dugas, La imaginación, 222. 
anarquista de trabajadores. En su casa no se habla de política ni religión, pero todos van a misa, por respeto a la devota madre.

Recuerda que su padre tampoco habla de la Guerra Civil, ni de ideologías; sólo lo hace de convicciones éticas, que no hay que confundir con convicciones morales. Su padre le habla del sentido de la vida, de cómo afrontarla. Seguí rememora que una de ellas es ponerse en el peor de los casos y enfrentar la vida sin temor a la muerte. ${ }^{134}$

Con su madre, Catalina de la Riva, también vasca, mantiene una relación distinta. De ella habla con extrema ternura, y confiesa que en un momento dado sufre de complejo de Edipo. Su madre lo llama "el gallego", y con ella tiene mucho contacto físico y afecto, a diferencia de sus hermanos. Durante la Guerra Civil, su madre se queda en el País Vasco, mientras su padre permanece en Madrid, trabajando. Cuando termina la contienda, el 1 de abril de 1939, el reencuentro del matrimonio se celebra en Zaragoza, y el fruto de esa ilusión parece ser él. Ese año, se establecen definitivamente en Madrid.

Debido al ambiente de respeto y cariño que se respira en su casa, el fervor religioso de la madre es objeto de consideración por parte de toda la familia; por ese motivo, y también porque el respaldo económico de su familia lo permite, Javier Seguí estudia en un colegio religioso, aunque no de curas, sino de frailes. Seguí confiesa que cuando es muy pequeño se llega a plantear ser obispo anglicano casado, y sin limitaciones sexuales, por las ganas de dirigir a la gente.

Haber crecido en un ambiente religioso no hace de él una persona con fuertes convicciones católicas, aunque siempre respeta este credo; de hecho, va a misa todos los domingos y comulga. Tampoco se consideraba ateo; además, siempre le ha interesado el misterio de la vida y la muerte. Aunque le cuesta creer en un Dios castigador, considera razonable lo de "hacer el bien": le parece un criterio aceptable. Es mucho después, en el año 2006, cuando apostata y rechaza la religión radicalmente.

De sus amistades en la adolescencia recuerda al carmelita Ramón Chías, con quien estudia psicología. Traban amistad porque, según cuenta, son capaces de ironizar sobre todo lo que les rodea sin que eso suponga un escándalo para ambos. También le viene a la memoria el jesuita Repullés, con quien también estudia psicología. Y menciona, asimismo, a Don Andrés y Don Domingo, del que siempre comenta su manera de reflexionar y 
expresarse, y a Pablo Camacho, con quien comparte inquietudes y pasiones. ${ }^{135}$

Según Seguí, crece en un ambiente rodeado de amor. En particular, el que le profesa su madre. Él dice que de sus hermanos, José Miguel y María Victoria, es el único que estudia y siempre tiene buena conducta, de manera que su padre está muy orgulloso de sus hazañas. Y aunque no lo demuestra tanto como su madre, Seguí lo sabe. Con su hermano, con el que se lleva diez años, no mantiene ningún tipo de relación, y con su hermana la relación es la típica de niños de su edad.

Según cuenta, en su casa se lee mucho, pero las lecturas son las convencionales. Un día, en sexto de bachillerato, lee un ensayo de Unamuno que le fascina. Ése es el momento que considera como su iniciación a la lectura. A este autor le siguen Ortega y Gasset y todos aquellos ensayos filosóficos que le hacen ver cosas e intuir otras. ${ }^{136}$

Las lecturas eran las convencionales. Pero a mí las novelas no me interesaban nada. Hasta que un día, en sexto de bachillerato, me puse a leer un ensayo de Miguel Unamuno y aquello me fascinó. Ésa fue mi iniciación en la lectura. A partir de Unamuno, pues ya Ortega y Gasset. Mis lecturas eran todas ésas: ensayos filosóficos. Me hacían ver cosas, intuir cosas. Así que cuando terminé la carrera tenía la necesidad de seguir probando. ${ }^{137}$

También le vienen a la memoria los años en los que es reclutado por el Ejército. En el primer año, 1959, realiza las Prácticas de las Milicias Universitarias, servicio obligatorio que los universitarios prestan al Ejército español, con tan sólo diecinueve años. Más tarde, en 1964, espera destino como alférez de complemento en un cuartel de artillería antiaérea, cuerpo al que pertenece. Es destinado a Tenerife donde permanece unos seis meses y donde, como comenta, no lo pasa mal en ningún momento, porque siempre tiene la capacidad de inventarse un personaje y de disfrutar de la experiencia que está viviendo.

Los libros y las lecturas de Javier Seguí constituyen, sin ninguna duda, otro vehículo cognitivo fundamental para descifrar su imaginario. Hoy en día, este imaginario se nutre de sus autores favoritos, en los cuales busca actualmente las respuestas a todas sus inquietudes: "Resulta que cuando tú estás hablando de

\footnotetext{
135 Javier Segui, "Los curas de mi vida (08/08/2010)," (Madrid: Instituto Juan Herrera de la Escuela de Arquitectura de Madrid, 2010).

136 Seguí, 18 de febrero, 2014.

137 Seguí, 18 de febrero, 2014.
} 
cualquier persona, lo que es interesante es ver la bibliografía que usa." 138

A semejanza de Van Leyden, el personaje principal del libro El árbol mágico, de Sloterdijk, las novelas nunca le despiertan el menor interés.

\begin{abstract}
Van Leyden no conseguía distraerse con la lectura. Era en vano que abriera las amenas novelas de los jóvenes autores franceses. A los pocos capítulos, le aburrían aquellas historias en las que se repetía la misma combinación de aventuras galantes, raptos infames e intrépidos rescates; no podía leer diez páginas sin que un mensajero reventara el caballo por llevar una carta urgente, ni una doncella fuera conducida a la fuerza al nido de amor de un desenfrenado libertino. ${ }^{139}$
\end{abstract}

Respecto a los libros y escritores que le marcan especialmente, cuando se le plantea el reto -que acepta- de intentar recordarlos, las primeras referencias se remontan al año 1964, cuando empieza a estudiar en la Escuela Técnica Superior de Arquitectura de Madrid. Cita a Unamuno y Pierre Teilhard de Chardin, pero también a historiadores de arquitectura como Rudolf Wittkower, Bruno Zevi y Leonardo Benévolo. En 1996, cuando ingresa en la Universidad de Psicología, despiertan su interés Philipp Lersh, Jean Piaget y Sigmund Freud; y un viaje a París en 1968 hace que se rinda a filósofos como Sartre, René Huyghé y Camus, al que tiene la oportunidad de conocer personalmente. En este mismo año destaca las obras de Carlos Castañeda y Kimon Nocolaides. También en 1968, y ya en el Centro de Cálculo, distingue a Christopher Alexander, Broadbent (psicología), Tadeusz Kotarbinsky (praxeología), Noam Chomsky (gramática generativa) George Miller (psicología cognitiva e inteligencia artificial) y Eugene Galanter (psicología cognitiva). En el año 1970 descubre la interpretación y la hermenéutica, y con ella a nombres como Luigi Pareyson, Emilio Betti, Umberto Eco y W. Dilthey. ${ }^{140}$

Cada uno de estos autores, que entra en distintos momentos de su vida, despierta una temática nueva en su consciencia. A día de hoy, muchos de esos autores siguen formando parte del discurso de Javier Seguí. A ellos se añaden otros nuevos que irrumpen, de la misma manera que los anteriores, como una búsqueda incesante de respuestas a sus inquietudes.

\footnotetext{
138 Javier Seguí, entrevistado por Maria Brito, 25 de marzo, 2014, Grabación.

139 Sloterdijk, El árbol mágico. El nacimiento del psicoanálisis en el año 1785. Ensayo épico sobre la filosofía de la psicología, 53.

140 Javier Seguí, entrevistado por Maria Brito, 2 de julio, 2015, Grabación.
} 


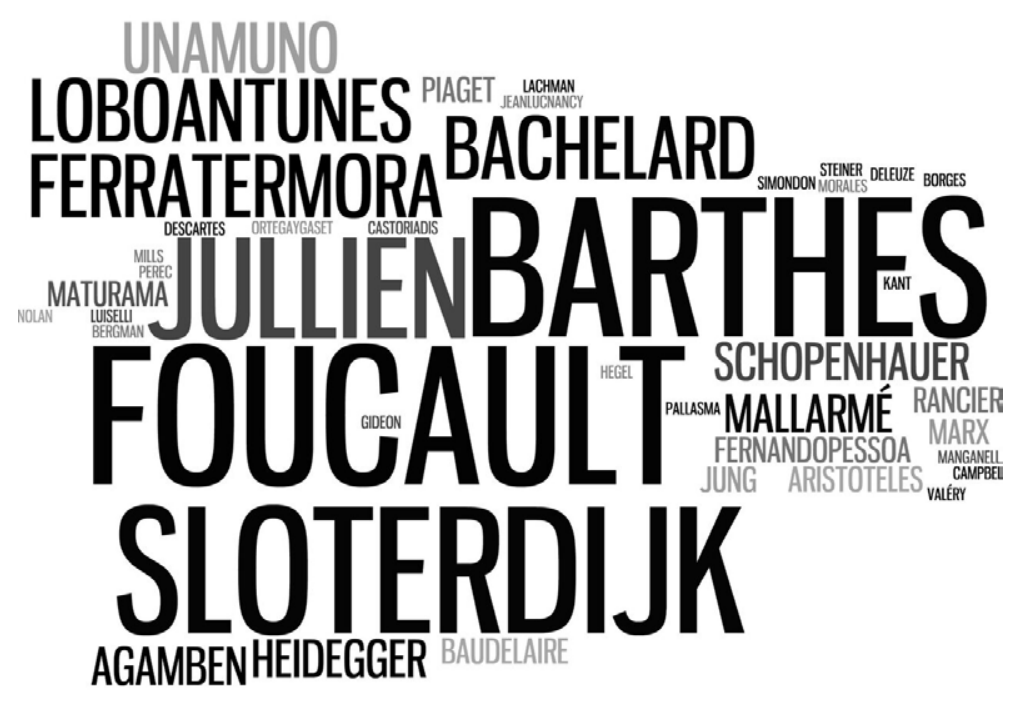

NUBE DE AUTORES, (2015). Cartografía efectuada con un programa informático,Wordle (disponible en Internet) a partir de las entrevistas realizadas a Javier Seguí de 2013 a 2015.

En relación a Unamuno, considera que es sin duda uno de los primeros escritores que le marcan profundamente; tanto, que habla constantemente del proyecto que presenta en 1957, todavía en la época franquista, en su primer año de estudiante en la E.T.S.A.M. El trabajo que propone el profesor consiste en hacer un proyecto para un Congreso Eucarístico. Según comenta él mismo, su propuesta es rompedora y causa bastante extrañeza en un establecimiento de enseñanza tan ortodoxo.

Me fui por ahí y me encontré un rebaño de ovejas, y le hice unas fotografías. Encontré un poema de Unamuno que tenía que ver con Castilla que hablaba de estar contra el cielo, casi aplastado... Esas dos cosas juntas significaban que mi proyecto era exactamente un sitio natural. Sin hacer nada, sobresaliente, claro. Los demás hacían capillas, pero no tenían la potencia poética que tenía el mío, que había encontrado un sitio maravilloso, natural. Había encontrado "el sitio". No hice un proyecto en un sitio. Ese sitio ya estaba fabricado. ${ }^{141}$

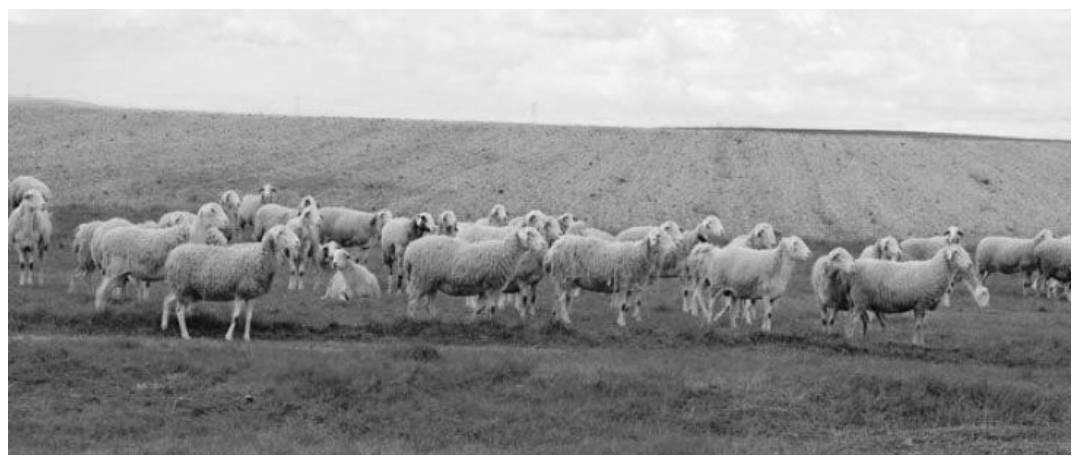


Tú me levantas, tierra de Castilla,

en la rugosa palma de tu mano, al cielo que te enciende y te refresca, al cielo, tu amo.

Tierra nervuda, enjuta, despejada, madre de corazones y de brazos, toma el presente en ti viejos colores del noble antaño.

Con la pradera cóncava del cielo lindan en torno tus desnudos campos, tiene en ti cuna el sol y en ti sepulcro y en ti santuario.

Es todo cima tu extensión redonda y en ti me siento al cielo levantado, aire de cumbre es el que se respira aquí, en tus páramos.

¡Ara gigante, tierra castellana, a ese tu aire soltaré mis cantos, si te son dignos bajarán al mundo desde lo alto!

HIPÓTESIS DEL PROYECTO REALIZADO POR JAVIER SEGUÍ. El proyecto que presenta Javier Seguí en el primer año es la suma del poema "Castilla", de Unamuno, y una fotografía de un rebaño de ovejas.

El empleo de poemas como complemento de sus proyectos es un descubrimiento que empieza como estudiante y que recurre con frecuencia a lo largo de su vida.. Cuenta que, cuando vive con sus padres, en una casa de guardias anexa a la vivienda paterna, suele leer en el jardín de la parcela. Su padre, incapaz de entenderlo, asegura que eso no es trabajar. Es entonces cuando Javier Seguí empieza a intuir que lo suyo es leer y escribir.

Seguí recuerda que también empieza a dibujar al mismo tiempo que a leer y a escribir - a los seis años- y que a los siete años ya quiere ser arquitecto. El ambiente de su casa propicia esta actividad: su padre dibuja, y su abuelo es pintor, por lo que, con apenas diez años, entra en una academia de dibujo. Comenta que en esa época admira a Miguel Ángel Buonarroti, y que, incluso, "hubo un momento que dibujaba como él."142 
El dibujo surge de manera espontánea en Javier Seguí y lo acompaña en su andadura. Dibujar se convierte en una de sus herramientas fundamentales, y ahora, ya alejado de la docencia, le sirve para liberarse de todo cuanto lleva dentro.

Para Seguí, el dibujo es comunicación y reflexión. Es la terapia por antonomasia para liberar inquietudes y para que el cuerpo establezca una relación con la mente, es dejar huella haciendo caer la máscara de la conciencia.
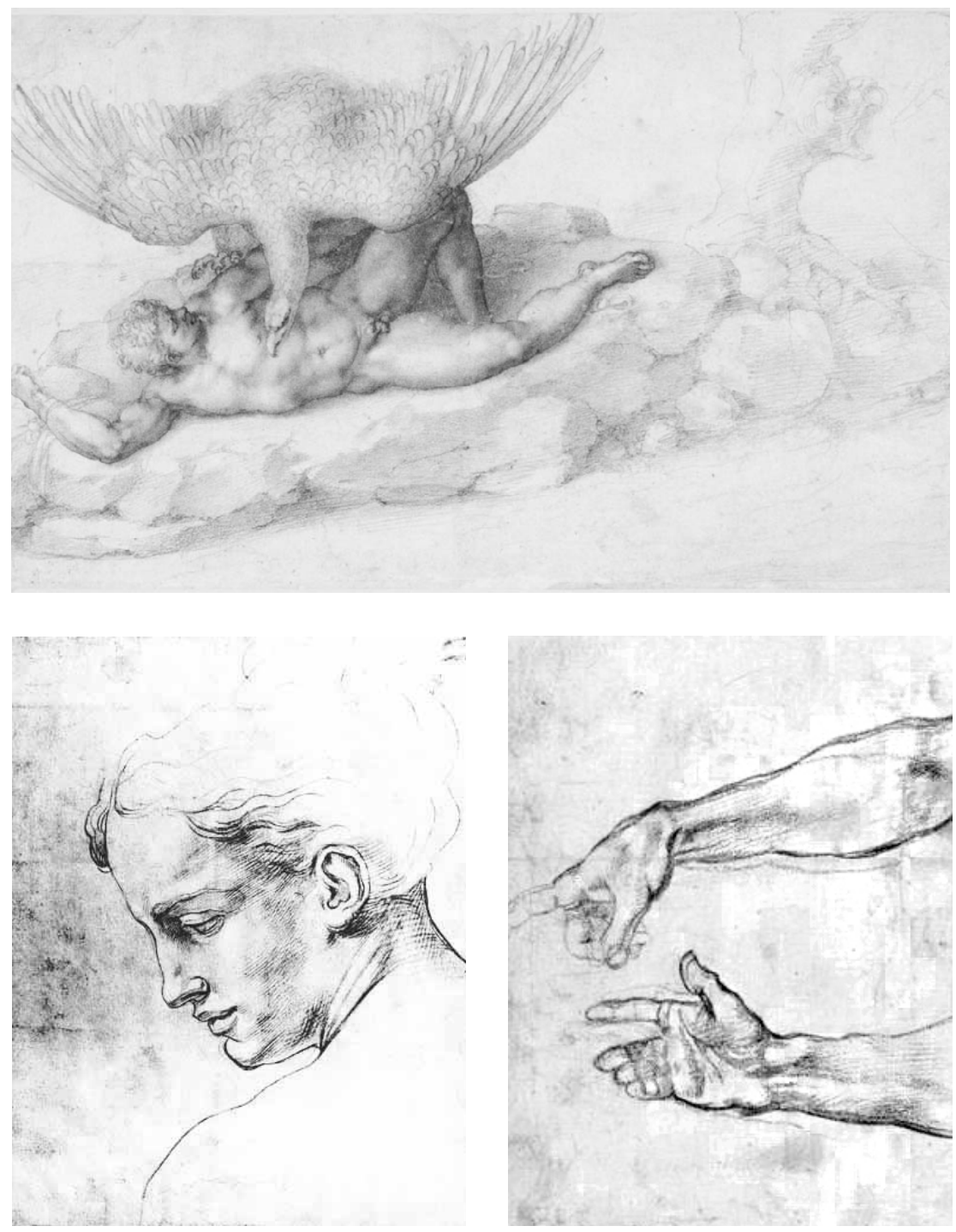

Dibujos de MIGUEL ANGEL BUONARROTI, (XV). 

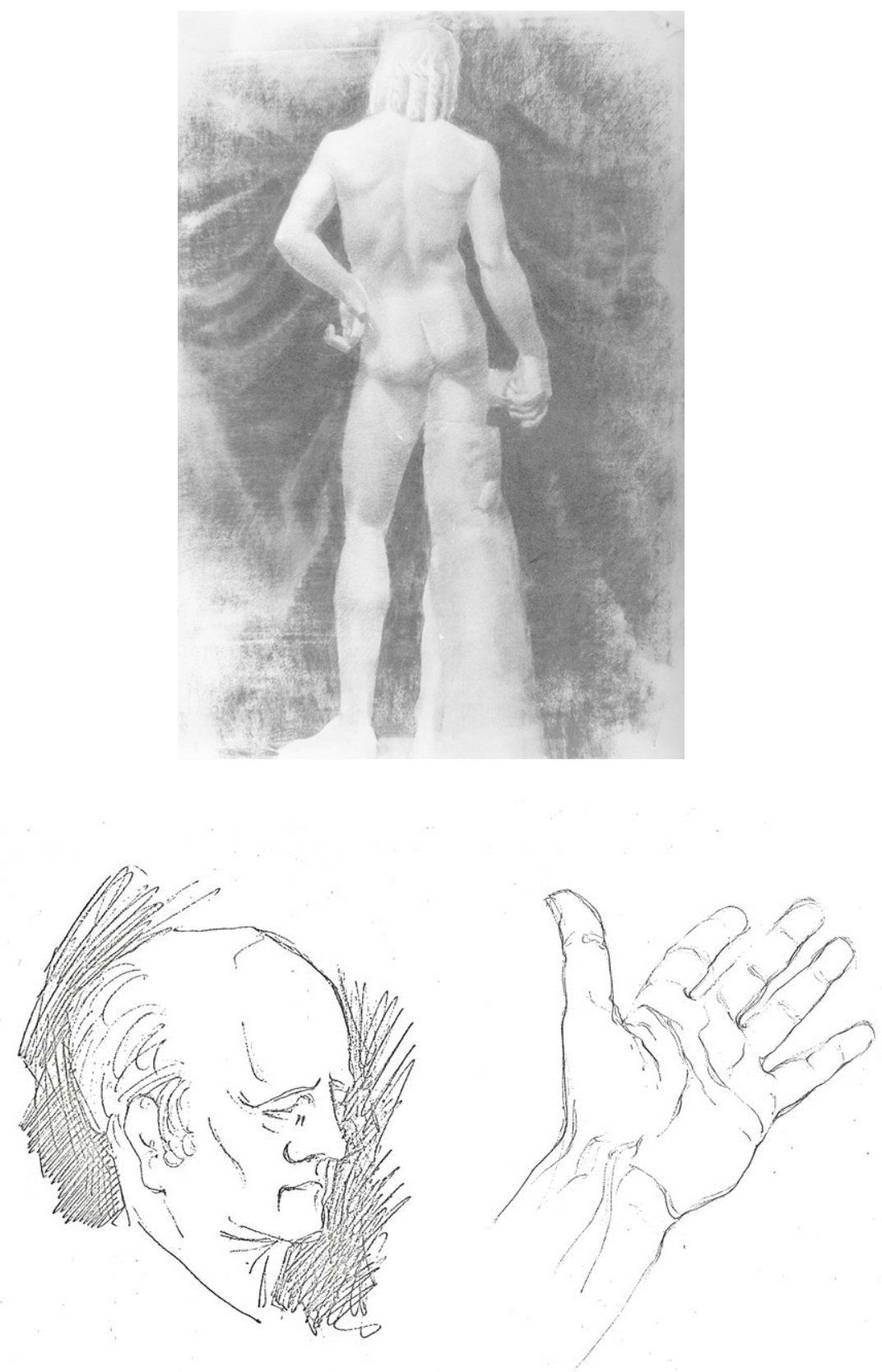

Dibujos de JAVIER SEGUÍ, (1965-1977). Para lograr el efecto que se persigue, se escogen dibujos de la época más tardía de Javier Seguí. Con el objeto de buscar la similitud grafica entre los dos autores, se recurre a la edición del color y de la luminosidad en un programa de edición de fotografía.

Su pasión por el dibujo y por el arte en general, hace que sea un asistente acérrimo de innumerables exposiciones. Una de ellas, determinante en la formación de su imaginario, es El vacío, de Yves Klein, que vio en París, en 1958, en la galería Iris Clert. En ella, el vacío es elevado a la categoría de arte, y la obra de arte es precisamente la desaparición del objeto. El objeto desaparece, 
dando paso a toda la materia sensible susceptible de ser rellenada por su observador.

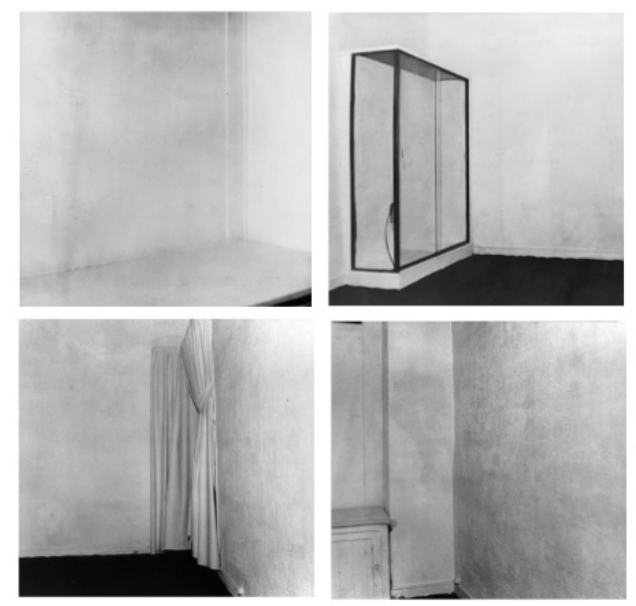

EL VACIO, (1958). Yves Klein.

Hay que destacar, también, los Encuentros de Pamplona, que se celebran entre el 26 de junio y el 3 de julio de 1972. En esa ocasión, ya trabajando en el Centro de Cálculo, tiene la oportunidad de desarrollar su trabajo utilizando un ordenador y en colaboración con José Luis Alexanco, famoso pintor y escultor español, caracterizado por el abandono de la pintura como fin en sí, y con Luis de Pablo, conocido compositor de música -ópera, principalmente. Allí reciben a la familia Huarte, bajo cuyo mecenazgo ven la luz en 1961 el famoso edificio residencial Torres Blancas, en Madrid, obra del arquitecto Francisco Javier Sáenz de Oiza, y la revista Nueva Forma, dedicada a la arquitectura y el arte.

Los Encuentros de Pamplona son decisivos en los cambios que se producen cuando concluye la era franquista, en pro de la pintura informalista y el avance de la abstracción. En estos encuentros, las manifestaciones artísticas no se encierran en una sala de exposiciones, sino que toman toda la ciudad, promoviendo los espacios públicos con happenings coordinados por el profesor Ignacio Gómez de Liaño. Aquí se expresan movimientos internacionales como el Fluxus o el Situacionista. Destacan nombres como los músicos John Cage, David Tudor, Steve Reich o Silvano Bussotti; la bailarina Laura Dean o el artista gráfico Dennis Oppenheim. Así, queda clara la "abolición de fronteras entre campos creativos y tradiciones culturales", en palabras del comisario de la exposición, Fernando Huici. ${ }^{143}$

\footnotetext{
143 Museo Nacional Centro de Arte Reina Sofia, "Los encuentros de Pamplona 25 años después," Museo Nacional Centro de Arte Reina Sofia,1997, 28 de julio de 2014: http:// www.museoreinasofia.es/exposiciones/encuentros-pamplona-25-anos-despues.
} 


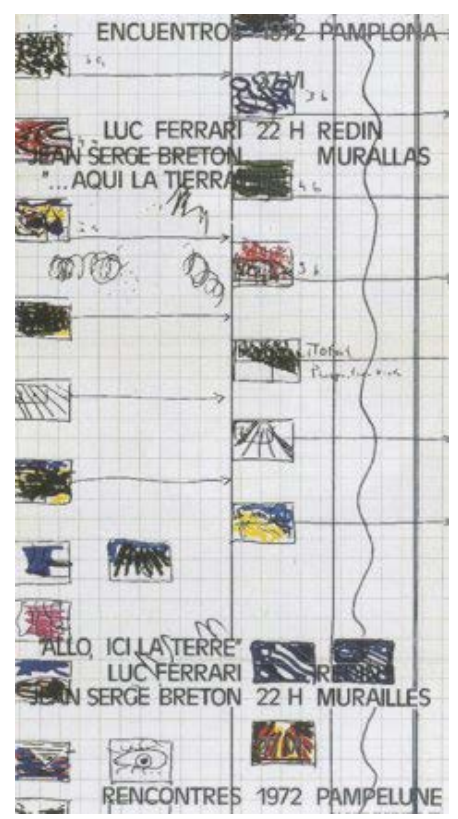

CARTEL DE LOS ENCUENTROS DE PAMPLONA, (1972). Biblioteca y Centro de Documentación, Museo Nacional Centro de Arte Reina Sofía Madrid.

También los viajes inundan su imaginario de múltiples imágenes. En relación al mundo fuera de su entorno cercano, el primer viaje que realiza es en 1955, y con él que confiesa sentir por primera vez "vergüenza ajena de ser español" es cuando su padre lo envía a Suiza con unos amigos suyos para que estudie en el instituto. Con sólo quince años aprende a hablar francés; cuando sale de España. ${ }^{144} \mathrm{~A}$ la vuelta sabe que algo ha cambiado, pero no se molesta en preguntarle a su padre qué ocurre, ya que confía en descubrirlo tarde o temprano.

En 1956 Javier Seguí visita París y es cuando toma "conciencia de la aberración que suponía vivir en España". ${ }^{145}$ En ese viaje, en compañía de un grupo de adolescentes de su misma clase social, se da cuenta de la visión que desde ese círculo se tiene del mundo; y le horroriza.

Salir de España, conocer otras culturas e ideologías siempre supone una herramienta de extrañamiento para Javier Seguí. De esos viajes, recuerda muchas "imágenes-fuerzas", decisivas a la hora de conformar su imaginario. Seguí recalca, con orgullo, la confianza de su padre en viajar como herramienta decisiva para su formación. Recuerda frecuentemente sus palabras: "aprovéchate, que yo puedo en este momento ayudarte y no sé lo que voy a durar."146 
En el viaje de Fin de carrera, que realiza en 1964, Seguí tiene la oportunidad de visitar los clásicos de la arquitectura más académica. Visita Egipto, donde contempla sus imponentes pirámides; el Partenón, en Grecia y la basílica de Santa Sofía, en Turquía.

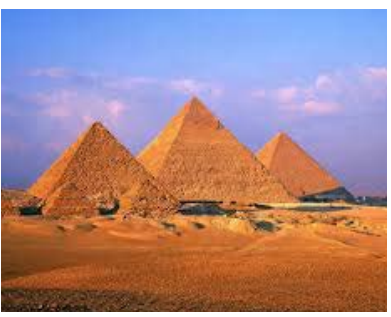

PIRÁMIDES DE GIZA, Giza Governorate, Egipto, (2500 a.C.).

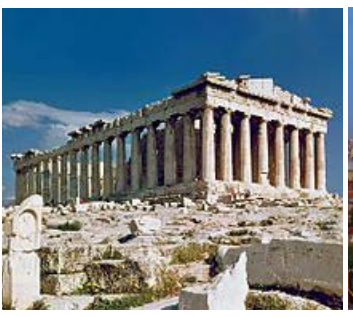

PARTENÓN, Atenas, Grécia, (447 y 432 a.C.).

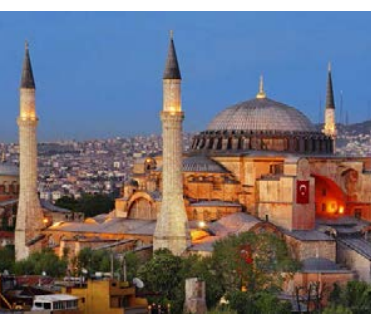

BASÍLICA DE SANTA SOFÍA, Estambul, Turquia,(537)..

El año 1968 es el más fructífero en este sentido, ya que Javier Seguí vive de cerca grandes revoluciones sociales y culturales, conoce nuevas ciudades, disfruta del descubrimiento de numerosos autores y se deleita con la obra de artistas y museos de su predilección.

El recorrido empieza en un París inflamado en ese momento por la Revolución de Mayo del 68, donde estudiantes y obreros se unen contra la sociedad de consumo. Empapado de esta atmósfera reivindicativa, descubre a escritores como Camus, Sartre y René Huyché; todos ellos polémicos filósofos que pasan a engrosar su formación epistemológica.

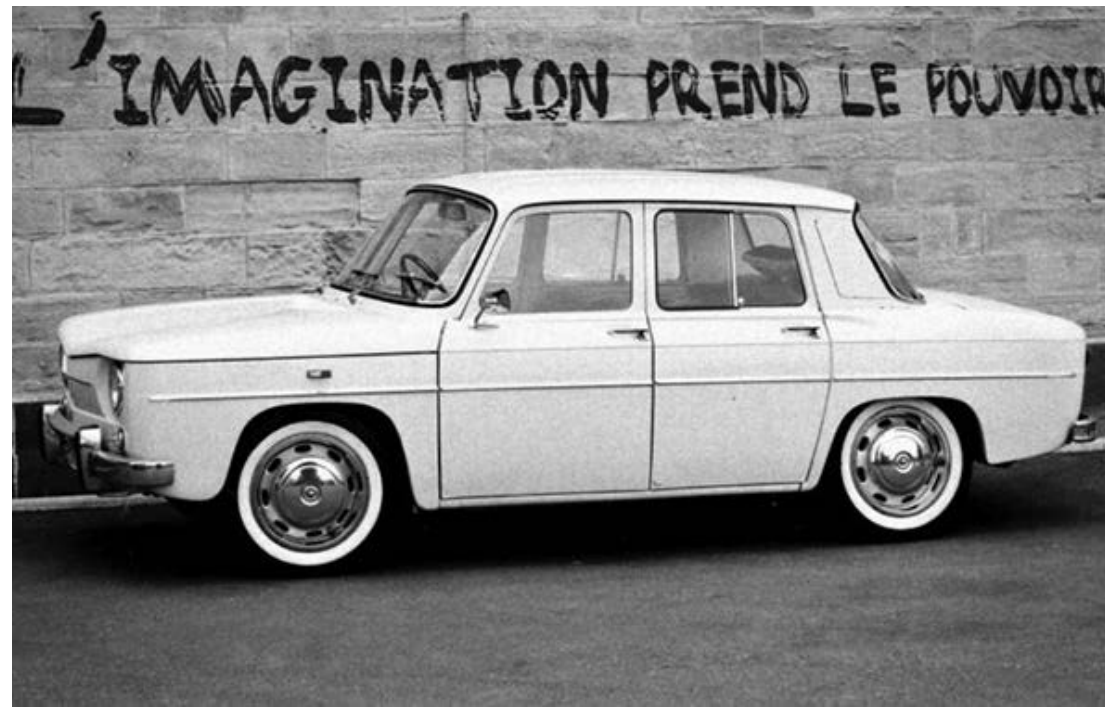




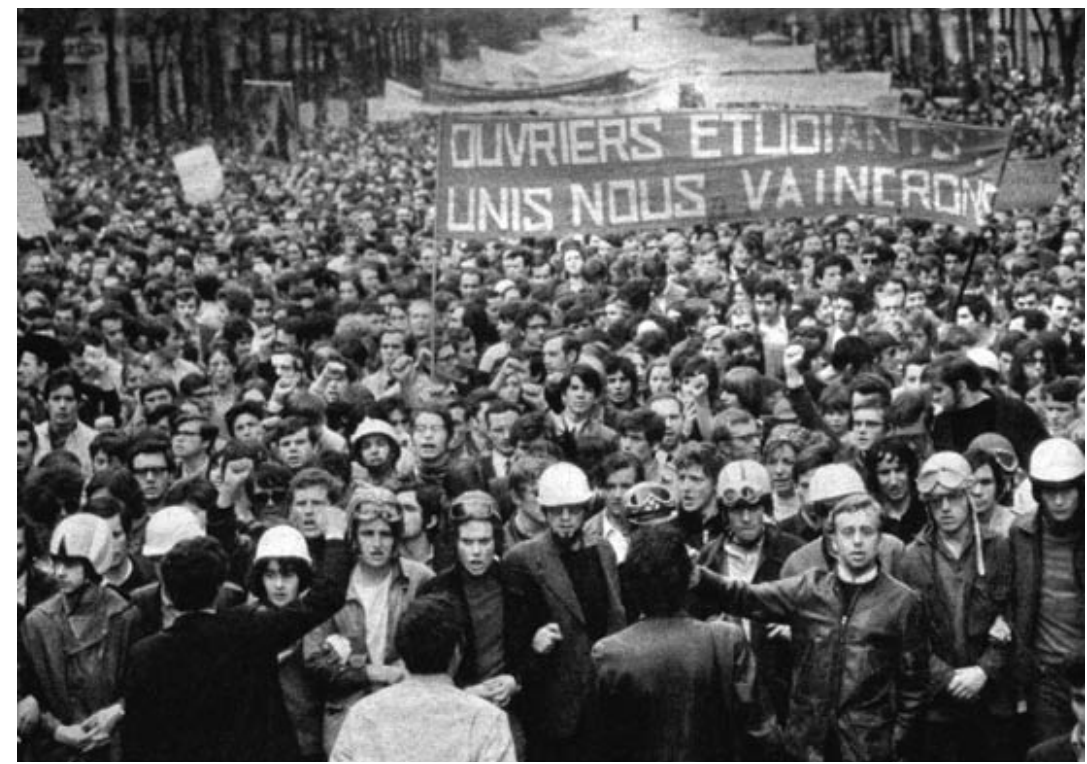

MANIFESTACIÓN EN PARÍS, (1968).

Poco después vuela hacia América y comienza su viaje por Nueva York, grabado en su memoria como un momento de gran emoción, pues allí puede ver en vivo las grandes obras de algunos de los pintores que admira. Admite que lo que más le impresiona es el Guernica de Picasso, que por aquel entonces se encuentra expuesto en el MoMA; las obras de Kandinsky, uno de sus pintores de referencia, en el Guggenheim; y también la obra de los grandes impresionistas, exhibida en The Metropolitan Museum.

Después viaja a San Francisco, ciudad en la que en ese momento se vive el gran movimiento hippie y donde entra en contacto con la historia de Felix Marcuse, responsable junto con su socio, Julius Remmel, del boom inmobiliario de Alameda (San Francisco) a finales del siglo XIX.

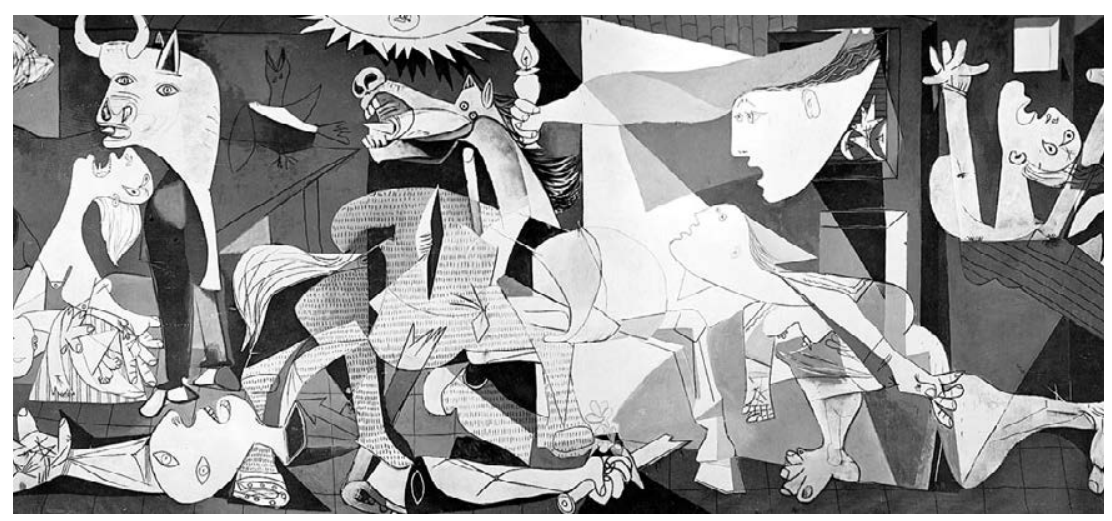

GUERNICA, (1931). Pablo Picasso. 


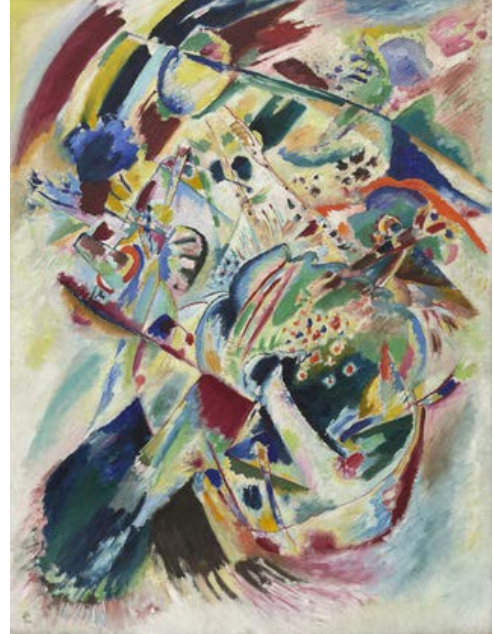

PANEL PARA EDWIN R. CAMPBELL No. 4, (1914). Vasili Kandinsky. Cuadro expuesto en el MoMA.

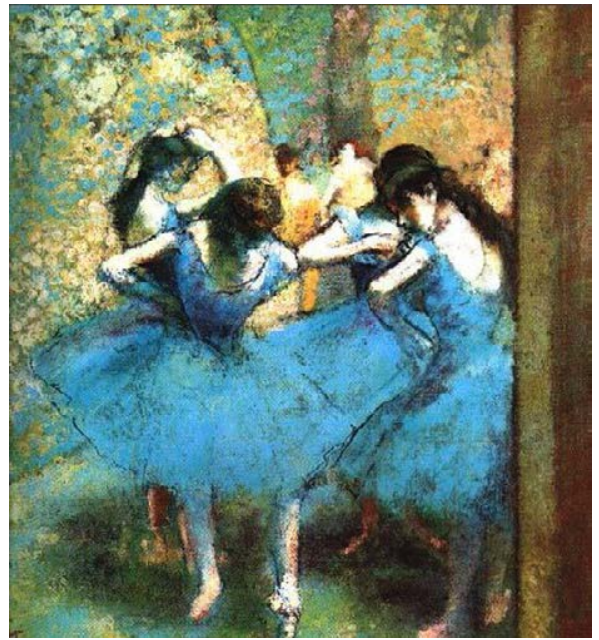

BAILARINAS AZULES, (1890). Edgar Degas, expuesto en The Metropolitan Museum.

A continuación se desplaza a México DF, capital en la que se familiariza con la historia de los exiliados mexicanos, pero también con la obra literaria de Juan Rulfo. Lo más impactante, sin embargo, es conocer la obra de Félix Candela. Este arquitecto con vocación científica es famoso por sus superficies paraboloides hiperbólicas -cascarones- en acero y hormigón armado. La principal característica de estas superficies es que, aunque curvadas, se pueden construir con líneas rectas. Esta técnica, que también utiliza el arquitecto Gaudí en el techo de la Sagrada Familia (1883), es lo que más fascina a Javier Seguí, un enamorado de la geometría.

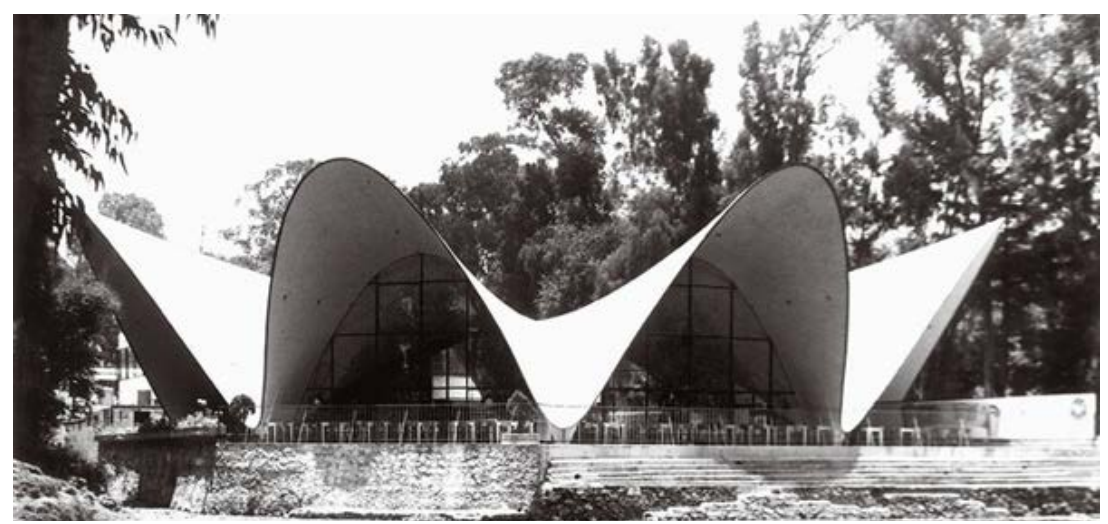

RESTAURANTE CANDELA MANANTIALES, Xochimilco, México, (1958).

Félix Candela.

Consciente de la importancia de viajar para moldear un imaginario, Javier Seguí empieza a llevar a sus hijos de viaje en 1968, cuando su hijo Miguel tiene tan sólo tres años y su hija Nerea, uno. En este primer viaje familiar, a Londres, Javier Seguí, que acaba de ingresar en el Centro de Cálculo de la Universidad de 
Madrid, comienza a interesarse por el mundo esotérico. En 1971 realiza, incluso, un curso de astrología.

Tanto el esoterismo judío como la numerología, la gematría, el gnosticismo/magia y la astrología cobran más fuerza en su imaginario en este viaje, en especial debido a Aleister Crowley, el polémico ocultista y mago inglés, con quien traba relación. Es, en palabras de Seguí, personaje "curioso", bisexual y consumidor asiduo de toda clase de drogas. Quienes lo rodean se ven obligados a sufrir sus locuras, sus excentricidades y sus desvaríos. Su vida, marcada por el esoterismo y los radicalismos extremos, cautiva a Seguí y deja una huella imborrable de ese viaje.

El clímax de esta mística llega en una visita a Stonehenge. El monumento megalítico queda grabado a fuego para siempre en su imaginario y, a semejanza del crómlech vasco, del que siempre habla Jorge de Oteiza, es un espacio que invita a la meditación y está nimbado del misticismo inherente a su indescifrable función.

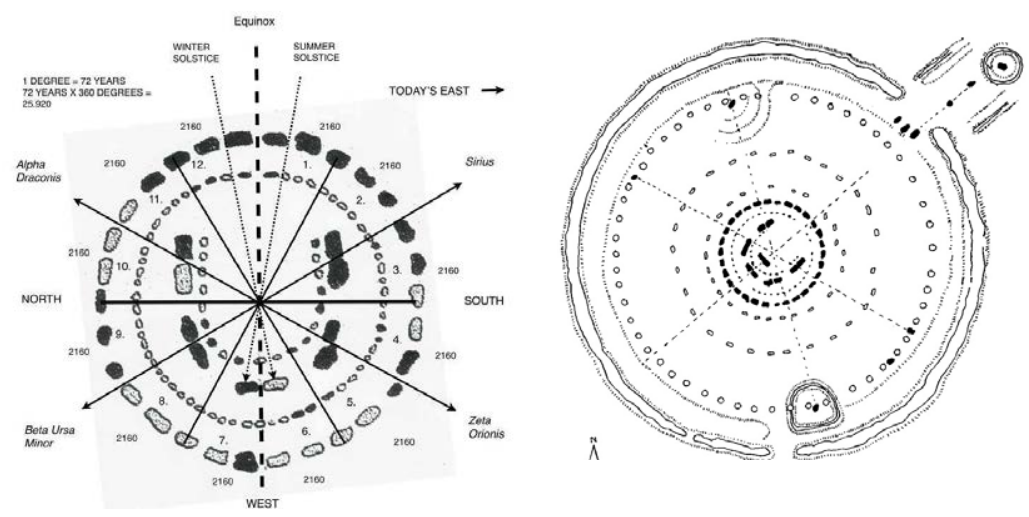

STONEHENGE, Amesbury, Inglaterra, (3500 a.C.).Plantas de estudio del movimiento solar, de la orientación de las estrellas y de los equinoccios.

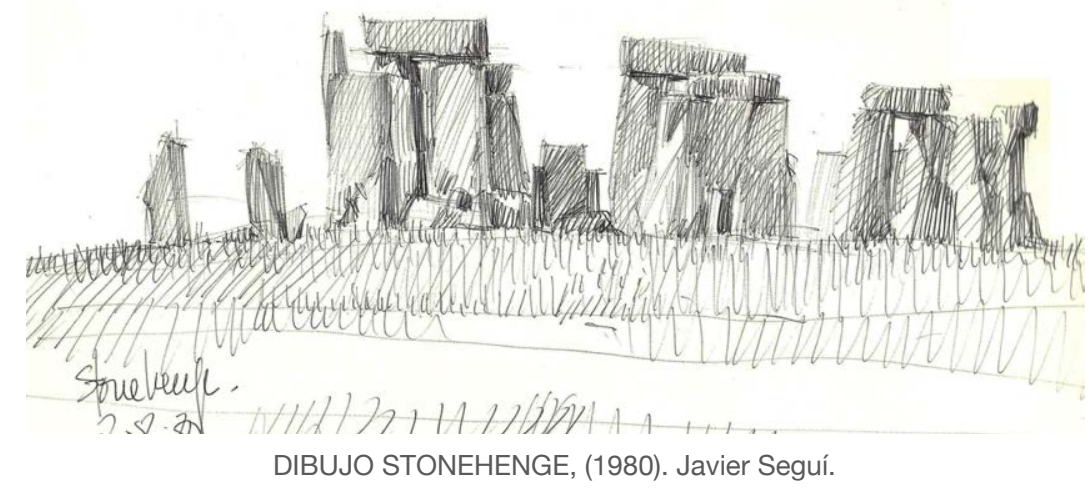

En 1970 vuelve a París, y tres años más tarde viaja a Brasil (São Paulo y Recife) acompañando a un grupo de artistas que acude a la XII Bienal de São Paulo, un encuentro de arte internacional. 
En la Bienal, entra en contacto con artistas chilenos y tiene conocimiento de la revolución que se vive en ese momento contra la dictadura de Pinochet. Seguí forma parte de la comitiva española, compuesta por artistas como Aurelia Muñoz, Miguel Berrocal, Andrés Cillero, Luís Lugan, Juan Martin de Vidales y el Equipo Zarpa. La propuesta de estos artistas es que el público pueda interferir directamente en la obra a través de su manipulación. En el catálogo de la Bienal, cabe destacar las palabras del comisario, Ceferino Moreno Sandoval:

En el inacabable mundo del arte y bajo la anchura de su palabra tienen acomodo todas las posibilidades de la imaginación a condición única de su "intencionalidad artística". Hay un arte para la mera contemplación, confortable. Otro posibilitador de elucidaciones matemáticas, geométricas y filosóficas. También un arte para inquietar, para denunciar, para subvertir. (...) Afirmaba Schiller que la esencia del arte era el juego y Huizinga que el espíritu del juego, con sus específicas normativas creadas frente a los impulsos ciegos, era anticipador de la cultura. ${ }^{147}$

En 1975 y 1976, ya como catedrático, visita nuevamente París con su grupo, Arkisist, formado en el ámbito de la Unesco. En el congreso al que asisten, tiene la oportunidad de conocer personalmente a Ernst Neufert. Como se puede leer en la publicación mensual de la Unesco de ese año, Arkisist se funda con el objetivo de crear un sistema mundial de información para los arquitectos y los especialistas en ordenamiento urbano y rural.

España contribuye a la creación de un sistema mundial de información para los arquitectos: En la Sede de la Unesco (París) acaba de firmarse una declaración relativa a la creación de un sistema mundial de información para los arquitectos (ARKISIST). Los tres promotores del proyecto, el gobierno español, la Unión Internacional de Arquitectos (UIA) y la Unesco, han decidido que el estudio de viabilidad y la instalación definitiva de ARKISIST en España sean financiados por el gobierno de este país, que ha donado con tal fin la suma de 218.000 dólares que administrará la Unesco. Por su parte, la organización se encargará de realizar el estudio y se ocupará de los aspectos técnicos y administrativos del proyecto. Finalmente, la UIA prestará la asistencia profesional de sus especialistas. ${ }^{148}$

Ese mismo año, y con la subvención de la ONU, Seguí recuerda emocionado su viaje a Canadá (Vancouver), donde conoce a Paolo Soleri, un artesano que vive en el desierto de Arizona.

\footnotetext{
147 "XII Bienal De São Paulo," ed. Fundação Bienal de São Paulo

148 "Latitudes y longitudes," El Correo - Publicación mensual de la UNESCO1977, 38.
} 
Soleri convoca cada año a estudiantes de arquitectura para erigir una ciudad ideal en el desierto de Arizona, a la que llamó Arcosanti. Se trata de una ciudad experimental de la Fundación Consanti, cuya construcción da comienzo en 1970 y que tiene por objeto ser un laboratorio urbano.

La ciudad, basada en la Arcología -a partir de las palabras arquitectura y ecología, propuesta por Paolo Soleri-, plantea varios edificios-ciudad con una estructura multiusos que contempla no

sólo una habitación unifamiliar, sino también un anfiteatro, un laboratorio y el centro de música CollySoleri. ${ }^{149}$
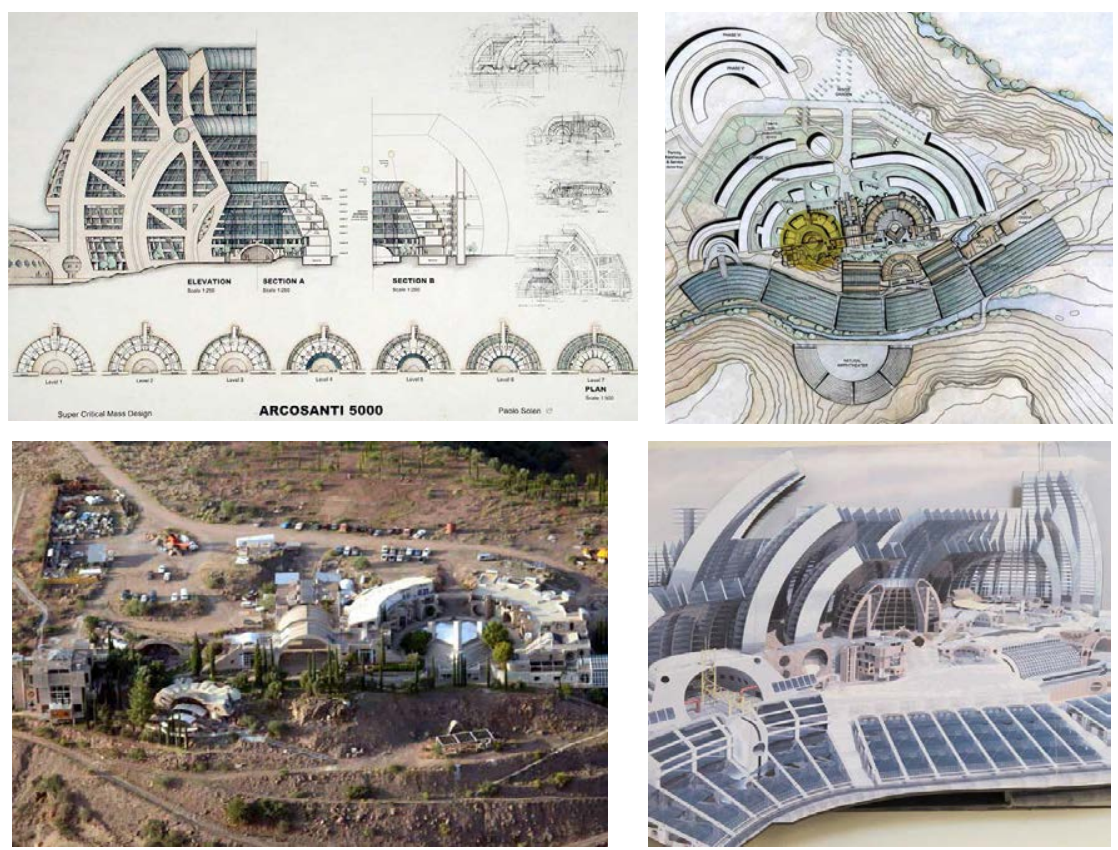

ARCOSANTI, desierto de Arizona, Estados Unidos, (inicio:1970). Paolo Soleri. Sección, master plan,render y fotografía del estado actual.

149 En su página oficial de Internet se puede observar el crecimiento de la ciudad, ver imágenes y hasta efectuar donativos para ayudar a su crecimiento. La página, asimismo, recoge algunos pensamientos interesantes de Paolo Soleri: "La más reciente reorganización del espacio nos desplaza hacia un punto más autoconsciente de la realidad. Yo lo llamo la Alternativa Lean en contraste con el consumo ilimitado de nuestra sociedad. Una arquitectura de procesos, el espacio de la organización de sí mismo, y el uso consciente del sol, en el movimiento incremental (las seis fases) hasta grados más altos de complejidad, el proceso de urbanización. Cada hoja de exedra ábside "sabe" más que la anterior, no por arte de magia, sino por la experiencia (del anterior). La enriquecedora experiencia de un creciente efecto urbano.", en Paol Soleri, "Arcology as Exemplified by Arcosanti 5000." 15 de agosto de 2015, Arcosanti: https://arcosanti.org/ node/10137. 
En 1982 vuelve a viajar con su familia. Primero a Brasil (Maceió), lugar del que rememora fascinado la visita a las ferias y los maestros perfumeros, que huelen a las personas y averiguan cuál es el perfume más adecuado para ellas. Es tal el interés que le despierta, que confiesa pasarse horas hablando con ellos para intentar dilucidar sus códigos analíticos de olores. Después, se desplazan a Perú, donde ve por primera vez el Machu Picchu -“Montaña vieja”, en quechua sureño- que, recuerda, le causa una profunda emoción, al igual que a sus hijos.

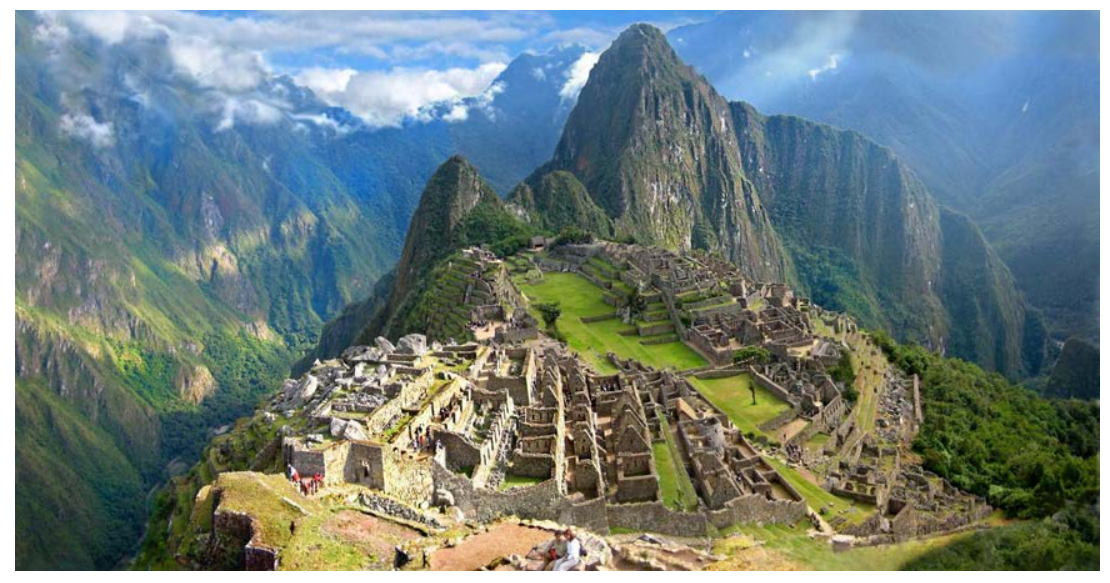

MACHU PICCHU ("Montaña vieja”), Perú, (siglo XV).

En 1984 visita Holanda (Delft) dos semanas, invitado por la Escuela de Arquitectura de la Universidad de Delft, para dar una serie de conferencias. Su anfitrión es un profesor impresionado con el lenguaje gráfico que Seguí introduje en el ámbito del dibujo en la E.T.S.A.M. Después se dirige a Suiza, donde efectúa la propuesta de una Clínica Psiquiátrica que no llega a construirse.

Ana Buenaventura, esposa y compañera, a la que Javier Seguí define como "detentora de su pasado", comparte con él toda una vida llena de experiencias, viajes, aficiones y numerosos proyectos profesionales. Motivado por Ana Buenaventura, especialista en diseño de moda, y por el padre de ésta, respetado peletero en el Madrid de esa época, y con la colaboración de la Fundación Universidad-Empresa y los empresarios de confección de la Cámara de Comercio de Madrid, empieza a concebir lo que acaba siendo el Centro de Estudios Superiores de Diseño de Moda de Madrid, teniendo la oportunidad de efectuar diversos viajes y conocer a personas que le marcan para siempre.

En el año 1985 recibe el encargo de viajar a Boston, Londres, Bélgica y Nueva York para conocer la estructura de algunos de los centros de moda, conocer a modistas y examinar sus almacenes. En Boston retoma el contacto con personas a las que ya 
conoce del MIT, pero Seguí reconoce que la escuela que más le sorprende es la de Nueva York, donde el famoso diseñador de moda Cristóbal Balenciaga tiene un almacén de vestidos que le causa gran impresión por sus dimensiones.
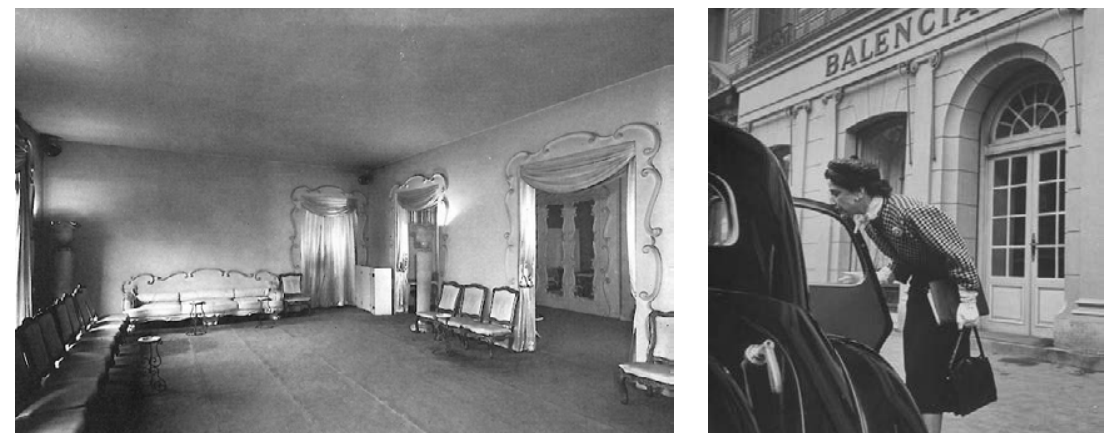

ESTABLECIMIENTO DE CRISTOBÁL BALENCIAGA, Nueva York, Estados Unidos, (1951).

En 1992 da comienzo una gran aventura que repite cada año con un amigo suyo sumamente excéntrico y acaudalado. Todos los años éste regala un billete de avión a todos sus compañeros de fatigas para que acudan allí donde estuviese anclado su barco en ese momento. Seguí se embarca en esta empresa veinte días todos los años. El primer destino es el Mediterráneo, pero en los años que siguen, se deleita con las aguas del Caribe, el Pacífico y las Islas Maldivas, el mar Rojo y, por último, el océano Índico.

En 1994, regresa a México - Jalapa, Guadalajara y Veracruz donde conoce a uno de sus grandes referentes en el mundo de la arquitectura: Danilo Veras. Este arquitecto mexicano deja tal impronta en él, que, años más tarde, al reflexionar sobre diversos asuntos de su vida, Seguí descubre la importancia que reviste este encuentro y el modo singular de como este arquitecto dibuja las casas con el movimiento de su cuerpo.

Hasta 2010 sigue fiel a su cita anual en el barco, que se extiende a lo largo de dieciocho años. También hasta esta fecha, tiene citas bianuales en Chile y México, donde realiza ponencias comunicaciones, conferencias, exposiciones o cursos de doctorado. Relata que en este circuito siempre aprovecha para pasar por Nueva York, con el fin de visitar a sus amigos y ver alguna exposición.

Sus viajes son determinantes para su postura crítica y para desarrollar de su "mapa mental nutrido de imágenes, cuyas fuentes directas y más valiosas son aquellas que la arquitectura, al experimentarse, proporciona a los sentidos."150 
Desencriptar sus imágenes - no sólo las visuales - es descubrir que su imaginario está "teñido de ideologías y de todo lo que nos han enseñado."151 Ellas determinan el temperamento y "no dejan de transformarse y de crecer," ${ }^{152}$ en la misma medida que el individuo no deja de mutar y crecer con ellas. Destapar estas idiosincrasias es destapar la primera huella que revela como el "Seguí que aprende" determina el "Seguí que enseña". 



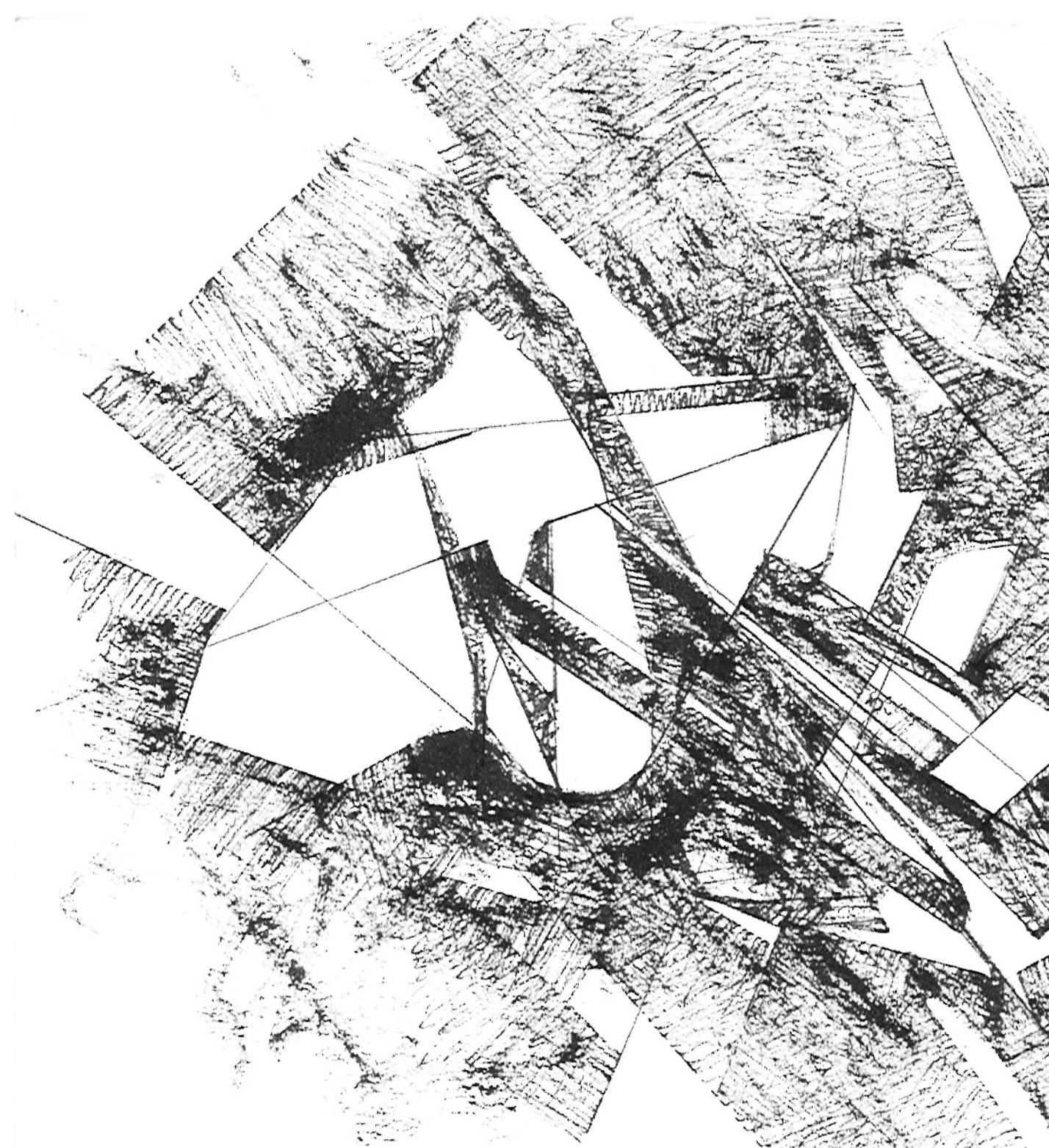


2. reflexionar 
Cualquier dato se vuelve importante cuando se lo conecta con otro. La conexión modifica la perspectiva. Induce a pensar que todo aspecto del mundo, toda voz, toda palabra escrita o dicha no tiene el sentido que percibimos, sino que nos habla de un secreto. El criterio es simple: sospechar, sospechar siempre. Se puede leer entre líneas incluso una señal de dirección prohibida. ${ }^{153}$

En las conversaciones mantenidas en los dos últimos años, Javier Seguí comenta que, en determinado momento, siente la necesidad de reinventarse a partir del vacío, de "buscar exactamente la parte más básica, más elemental que queda después de la experiencia de haber hecho todo lo anterior." 154

Aunque Seguí considera que "dentro de la burguesía se pueden tener ideas raras", sabe que hay que romper con algunas huellas de su imaginario para poder llegar a otro estadio de comprensión. Después de más de cuarenta años en la docencia, Seguí confiesa que, a día de hoy, no se ha podido liberar todavía. ${ }^{155}$

Como se menciona anteriormente, a Seguí le empieza a extrañar su condición social y el modo de pensar de las masas cuando viaja por primera vez a París. Sus viajes son cruciales para conocer a determinadas personas, entrar en contacto directo con revoluciones del proletariado y vislumbrar la pobreza y la miseria en la que vive mucha gente. La primera vez que sale al extranjero, a Suiza, en 1955, y al pisar también por primera vez un estado democrático, comienza a tomar conciencia de lo que supone la dictadura que gobierna España en el momento. Al año siguiente, cuando visita París, se adentra en otra cultura y conoce por primera vez a un homosexual, discípulo, además, de Albert Camus; la vergüenza que siente, le afecta más, si cabe.

En 1960, año en el que conoce a Ana Buenaventura, también traba relación con el padre de la que más tarde será su mujer. Éste es, según asegura, "rojísimo, pariente de Generales de Ejército rojo". Es entonces cuando empieza a escuchar despotricar de Franco, y también cuando comienza a leer a Marx y a tener conciencia de que hay un modo distinto de ver el mundo, más comprometido con los que no tienen sus mismas posibilidades económicas. En ese momento descubre su ateísmo, y cae en la cuenta de que ese "hacer el bien" que preconiza la Iglesia supone, sobre todo, ser solidario con las personas. No obstante, durante mucho tiempo sigue acudiendo a misa: "Empecé a odiar un poco a los ricos, porque me parecían unos gilipollas.

\footnotetext{
153 Umberto Eco, El péndulo de Foucault (Barcelona: DeBolsillo, 2004).

154 Javier Seguí, entrevistado por Maria Brito, 8 de octubre, 2013, Grabación.

155 Javier Seguí, entrevistado por Maria Brito, 18 de febrero, 2014, Grabación.
} 
Esta escuela era un avispero franquista, una cosa absolutamente acojonante. Es como ir tomando conciencia de las cosas que vas tocando a tu alrededor."156

Sin embargo, es su viaje a Brasil, cuando ya tiene cuarenta años, el que apuntala su ideología. Allí, donde la izquierda política es arrolladora, vive un auténtico despertar de la conciencia. Recuerda asistir allí a una homilía marxista radical, pronunciada por un cura rojo que hace que se replantee su manera de entender la religión y experimentar la primera epifanía ideológica de su condición social, que, como comenta: "hizo verme a mí con un espíritu bastante burgués, con creencias progresistas, pero absolutamente burgués." 157

Descubre de este modo que, con independencia de lo que piense, es su manera de actuar el principal reflejo de su ideología. Pero es en 1983, con la muerte de su hija Nerea, cuando manifiesta "su rebeldía contra el Dios personificado en los curas y lo coloca en el ámbito de la desesperación". ${ }^{158}$

Consciente de su condición personal, de todo lo que conoce y ha leído hasta entonces, y movido por esa revolución interior que nunca lo abandona, en el año 2006, acompañado por sus hijas Mairea y Ana, entrega una comunicación de apostasía al obispo de Madrid: "luego lo celebramos." 159

Para liberar su imaginario, anclado a la educación y la sociedad en las que está inmerso, hace falta, a su juicio, estrategias que le permitan borrar de la memoria toda clase de prejuicios; llevar a cabo un procedimiento radical para efectuar de nuevo el recorrido, pero sin repetir las reglas del anterior, con la voluntad de ir en contra de los propios hábitos adquiridos a lo largo del camino.

En la película ;Olvídate de mí! ${ }^{160}$, del año 2004, existe un proceso mediante el cual se pueden suprimir de la memoria determinados recuerdos. Estudios del año 2012 revelan que esta realidad ya es posible; la ficción se torna realidad. Investigaciones realizadas en el campo de la neurobiología ponen de manifiesto dos mecanismos neuronales distintos, a través de los cuales es posible bloquear voluntariamente los recuerdos: uno por medio de la supresión (direct supresión) y otro a través de la sustitución por

\footnotetext{
56 Seguí, 18 de febrero, 2014.

157 Seguí, 18 de febrero, 2014.

158 Javier Segui, "Los curas de mi vida (08/08/2010)", (Madrid: Instituto Juan Herrera de la Escuela de Arquitectura de Madrid, 2010).

159 Seguí, "Los curas de mi vida (08/08/2010)".

160 Eternal Sunshine of the Spotless Mind, Michel Gondry, (USA: Focus Feature, 2004), DVD
} 
otro más agradable (thought substitution). ${ }^{161}$

La memoria me hace siempre recordar a Lobo Antunes, que dice que, una cosa es la memoria y otra cosa es el recuerdo. La memoria es la imaginación, el ser interior dinámico. Para que la memoria funcione, tienes que olvidarlo todo. Entonces, los que se olvidan son los recuerdos; las situaciones concretas. El recuerdo es algo que se desencadena, como una película en un momento determinado; o la ves claramente, o no la ves. Lobo Antunes dice que el pasado es un presente atenuado. Lo que tienes almacenado perfectamente es como el cuadro de constantes, o de afectos, o de situación global donde se produce exactamente el acontecimiento; y eso lo recuerdas siempre porque es la configuración de tu cerebro, eso es la memoria. Y la memoria funciona cuando te olvidas de las cosas. Cuanto más olvides, más memoria tienes. Decía Lobo Antunes que a esos literatos que hacen libros llamados memorias, que les llamen recuerdos, porque no hay memorias. Hay una memoria, y es fundamentalmente imaginaria. La capacidad de manejar y mezclar imágenes, eso es la memoria. El recuerdo es una cosa muy concreta. La memoria es un resonador. Es el propio universo de tus vivencias resonando. ${ }^{162}$

Es tan necesario recordar, como olvidar. Ambos mecanismos son defensas que usa el cerebro para sobrevivir. La mente humana se halla repleta de recuerdos y memorias que constituyen la base de datos necesaria para la creación y, sobre todo, para la supervivencia. Por este motivo, y como ya comentámos anteriormente, el cerebro muchas veces borra algunos datos voluntariamente. Steve Rose, reconocido neurobiólogo y estudioso de la memoria, afirma que "hay una diferencia entre reconocer y recordar, y eso da varios matices a la memoria. El cerebro no está hecho para pensar, sino para sobrevivir, por eso los recuerdos son una mezcla de realidad y ficción."163

Partiendo de esta propuesta, uno de los procesos que Javier Seguí emplea en esta fase -sin obligaciones profesionales y en la que dispone de horas de reflexión- es dibujar sin parar y sin pensar; compulsivamente, porque desea vaciarse.

Mallarmé afirma que la función de la poesía no es vaciar o borrar lo existente, sino desbloquear aquellas cosas que la ideología deja petrificadas en la tumba del prejuicio y del temor. ${ }^{164}$

\footnotetext{
161 Roland Benoit y Michael Anderson, "Opposing Mechanisms Support the Voluntary Forgetting of Unwanted Memories" Neuron n.76 (2012).

162 Javier Seguí, entrevistado por Maria Brito, 4 de marzo, 2014.

163 El alma está en el cerebro, Eduard Punset, RTVE, 2011, Televisión.

164 Javier Seguí, Dibujar, proyectar (LXIX) - Vacío, vaciar (4) (Madrid: Instituto Juan
} 
Vemos el "imaginario del dibujar" como un deslizarse por un inmenso fondo de gestos, en tensión vaciante... fondo formante... figurante, en que flotan espectros, designios... "eidos" concisos que coagulan en "imágenes" (promesas o reversos figurativos), $y$, sin embargo, parecen querer diluirse en el encuadramiento mortuorio... de su aparición. ${ }^{165}$

Para llevar a cabo el proceso introspectivo e intelectual de vaciado, tal como afirma Perec: "haga el inventario de sus bolsillos, de su bolsa. Interróguese de dónde proviene el uso y el devenir de cada uno de los objetos que saque de ellos."166 Se concluye que es necesario catalogar todo aquello que se posee, para descubrir lo que, de alguna manera, domina al sujeto.

Para Rilke, éste es un requisito previo fundamental: percibir qué "colma" al individuo -palabras, gestos mecánicos-, para, después, poner en marcha el proceso del vaciado. ${ }^{167}$

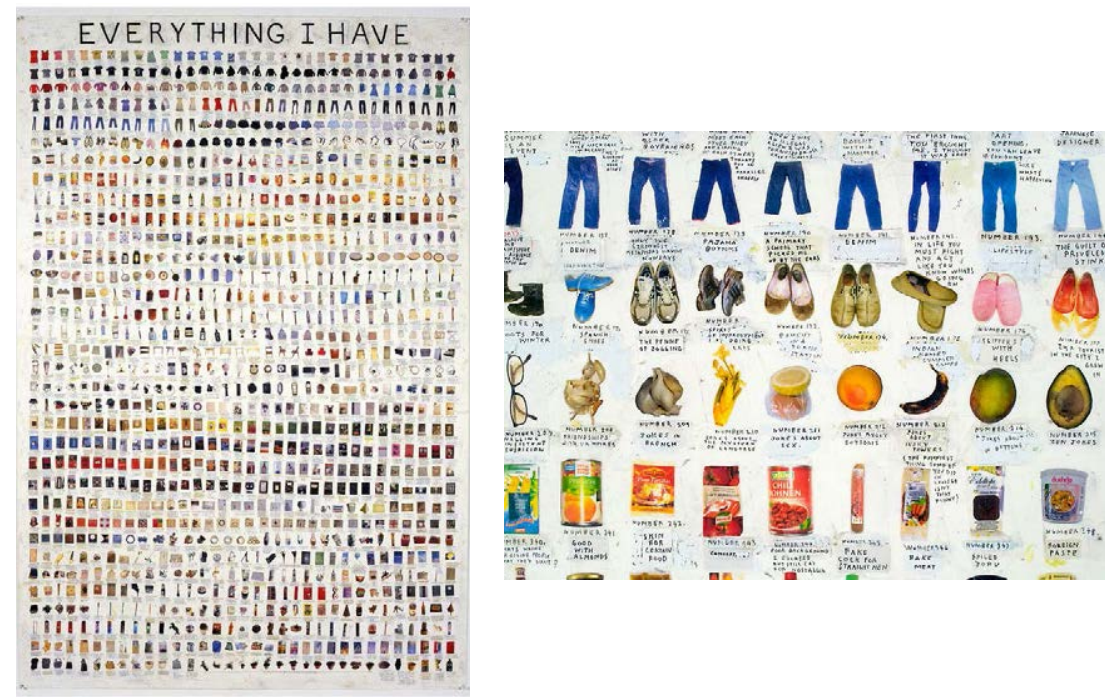

EVERYTHING I HAVE, (2009). Simon Evans. Exposición realizada en la galería neoyorquinaJames Cohan Galler.

La voluntad de romper el imaginario, tal como le ocurre a Seguí, nace de situaciones radicales, confrontaciones ideológicas que llevan a diseccionar y repensar las doctrinas establecidas hasta el momento, en el procedimiento de cada uno. Esta toma de conciencia exige un proceso de vaciamiento, de borrado de con-

4 Herrera de la Escuela de Arquitectura de Madrid, 2014), 8.

165 Javier Seguí, Dibujar, proyectar (LVIII) - El imaginario del dibujar (Madrid: Instituto Juan de Herrera de la Escuela Técnica Superior de Arquitectura de Madrid, 2013), 22.

166 Georges Perec, "Introducción," en Lo infra-ordinario (México, D. F.: Éditions du Seuil, 2008), 11.

167 Seguí, Dibujar, proyectar (LXIX) - Vacío, vaciar (4), 8. 
tenidos, para un renacer, un volver a empezar con la conciencia de lo recorrido. Sólo después se puede pasar a la siguiente fase, en la que se rellena de nuevo el contenedor, renombrando y añadiendo nuevos contenidos. Se trata de, como afirma Seguí "haber hecho un recorrido y volver a empezar con toda la frescura, sin prejuicios, sin arrastrar nada del anterior.

O arrastrando el anterior, pero diluido en otro tipo de experiencia. Ir directamente al grano, sin tapujos." 168

No recordar casi nada significa que he vivido casi toda mi vida con el piloto automático, arrastrado sin control por la corriente de lo cotidiano socializado, inmerso en la marea vital de los otros (los míos).

Recuerdo las cosas sonadas, las que me sacaron de mis casillas, las que supusieron tener que tomar el control.

Soy marea, tumulto, proceder impersonal que, en ocasiones, se resiste a la indiferenciación. ${ }^{169}$ 
reflexionar

2.1 vaciar

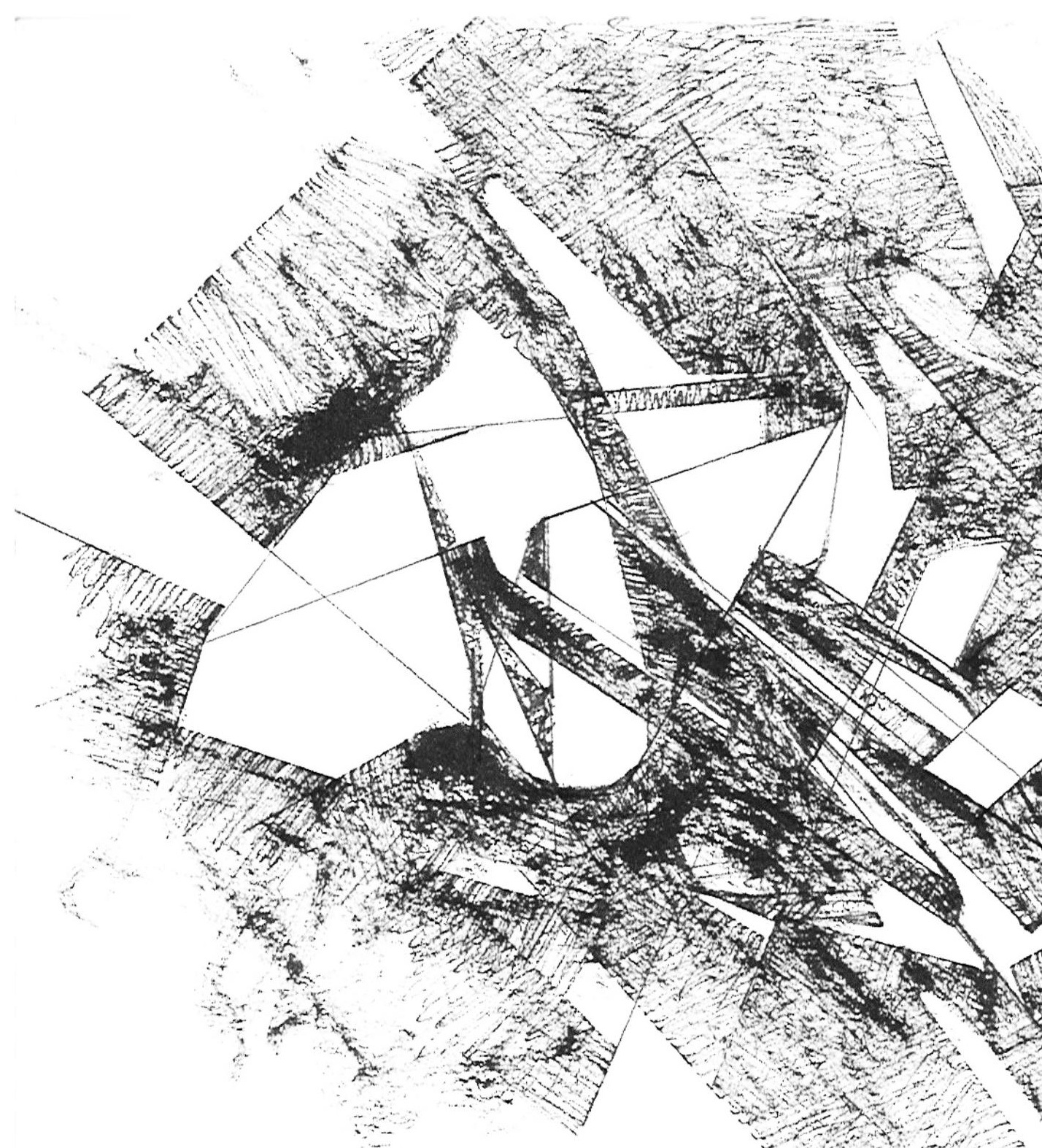


Turrell se quedó allí seis años, en un edificio de esquina. Había vaciado las habitaciones. Las había privado de sus funciones cotidianas. Había hecho un lugar desertizado -fábula del lugar vacío-: re-ficcionar (re-fabular). "Me interesan los lugares públicos desnudados, vaciados de su función." Vació todo y cerró las ventanas a la calle. Lugar para dormir y soñar. ${ }^{1}$

El vacío es el inicio de todo, el origen. "Del vacío nació el cosmos, del cual emana el aliento vital":?

Se mira sin ver y se le llama invisible; se escucha sin oír y se le llama inaudible; se palpa sin tocar y se le llama intangible; tres cosas inexplicables que, al confundirse, hacen la unidad. Su arriba no es luminoso; su abajo no es tenebroso. Serpentea indefinida e indistintamente hasta el retorno a la no-cosa... Se le califica de forma de lo que no tiene forma y de imagen de lo que no es imagen. ${ }^{3}$

Prada, en sus escritos sobre el vacío, ${ }^{4}$ menciona a algunos autores que son precursores de distintas maneras de interpretar esta cuestión. En la lectura poética designa embajador a Bachelard; en la espiritualista, a Lao Zi; en la plástica y artística, a Guido Morpurgo-Tagliabue, Renato Fusco y Cornelis van de Ven; y en la existencialista, a Kosme de Baraño, Heidegger y Fernando Espuelas.

Para Heidegger "el vacío no es nada, tampoco es una falta; en la materialización plástica juega el vacío como un acto fundante que busca forjar lugares"5 Javier Seguí afirma: "vacío es el lugar donde se operan las trasformaciones, donde lo lleno puede alcanzar la plenitud. En música, el vacío es el silencio; es la escucha."6

Aristóteles, con su noción de "mímesis" como imitación de la realidad, plasma el paradigma de lo que es en realidad el vacío y de cómo lo percibe el ser humano.

El dolor, como su correlativo el placer, en cualquier grado que se encuentre, debe servir para la defensa, y las percepciones, para hacer más fácil y más útil la defensa, deben indicar lo que ha producido el dolor, a fin de que éste pueda ser de an-

\footnotetext{
1 Javier Seguí, Dibujar, proyectar (LXVI) - Vacío, vaciar (1) (Madrid: Instituto Juan Herrera de la Escuela de Arquitectura de Madrid, 2014), 7.

2 Javier Seguí, Dibujar, proyectar (LXVII) - Vacío, vaciar (2) (Madrid: Instituto Juan Herrera de la Escuela de Arquitectura de Madrid, 2014).

3 François Cheng, Vacío y plenitud. El lenguaje de la pintura china., trad. Amelia Hernández y Juan Luis Delmont (Madrid: Biblioteca de Ensayo Siruela, 2008), 80.

4 Manuel de Prada, "Componer con vacío," Cuaderno de Notas, $n^{\circ} 9$ (2003).

5 Clara Janés, "Chillida y la fuga sin fin," Escritura e imagen (2013): 318.

${ }^{6}$ Javier Seguí, Dibujar, proyectar (LXVII) - Vacío, vaciar (2).
} 
temano evitado. La percepción es, pues, una función subsidiaria del sentimiento cuando se la considera desde el punto de vista de la protección del individuo. ${ }^{7}$
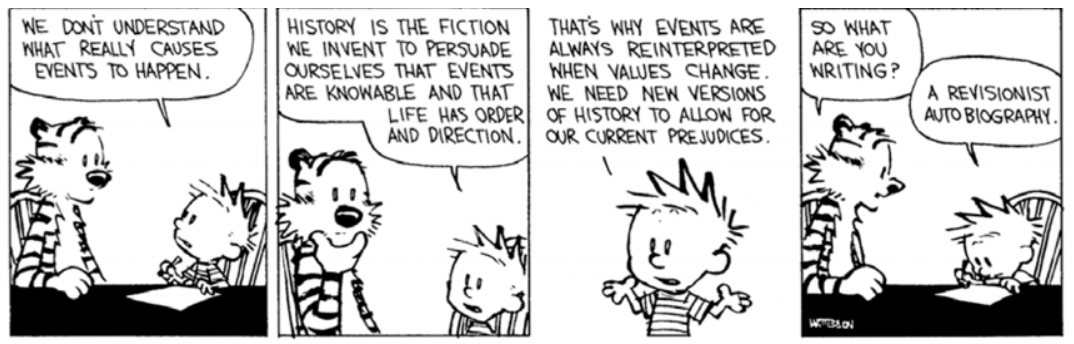

CALVIN \& HOBBES, (1985 - 1995). Bill Watterson.

Lo que se conoce como "real" es la construcción mental de la realidad que perciben la mayoría de las personas. Esta experiencia común, percibida de manera general y por la mayor parte de personas, condiciona las minorías. Es decir, de alguna manera, la percepción es una versión editada de la realidad y es misión del arte dar voz al sinfín de experiencias singulares, únicas y distintas de estas minorías.

El vacío y sus metáforas, sus conceptos y símbolos -como puede ser el cero-, sugieren, de inmediato, un importante contraste histórico: negación en Occidente y exaltación en Oriente.

En la corriente oriental, destaca el escritor chino François Cheng, que escribe: "el vacío, la quietud, el desapego, la insipidez, el silencio, la inacción son el equilibrio de universo, la perfección de la vía y de la virtud." Sobre su libro, Vacío y plenitud, Seguí concluye que el silencio es el vacío de la música, la supresión de ciertas palabras y el "no pintado" de la pintura. En esta misma línea de pensamiento se sitúa Zhuangzi, para quien el arte "significaba dejar ver el vacío." Según la cultura oriental, el vacío no es lo que "no se ocupa", sino aquello que circunda la forma.

Javier Seguí, citando la Biografía del vacío, de Albert Ribas, habla del vacío como un reclamo negado por Occidente, que rehúsa el cero a lo largo de gran parte de su historia. "No hay vacío, porque el vacío no es nada iy la nada no puede ser!". ${ }^{10}$ Seguí reflexiona acerca del vacío newtoniano, que señala la sencilla diferencia entre vacuidad y plenitud: "el vacío es, pues, ausencia de materia". ${ }^{11}$

\footnotetext{
7 Giuseppe Sergi, Las emociones (Madrid: Daniel Jorro, 1906), 25.

8 Cheng, Vacío y plenitud. El lenguaje de la pintura china.

9 Javier Seguí, Dibujar, proyectar (LXVII) - Vacío, vaciar (2).

10 Javier Seguí, Dibujar, proyectar (LXX) - Vacío, vaciar (5) (Madrid: Instituto Juan Herre-

ra de la Escuela de Arquitectura de Madrid, 2014).

11 Seguí, Dibujar, proyectar (LXX) - Vacío, vaciar (5), 9.
} 


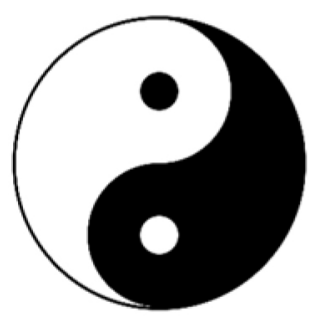

SÍMBOLO YIN-YANG.

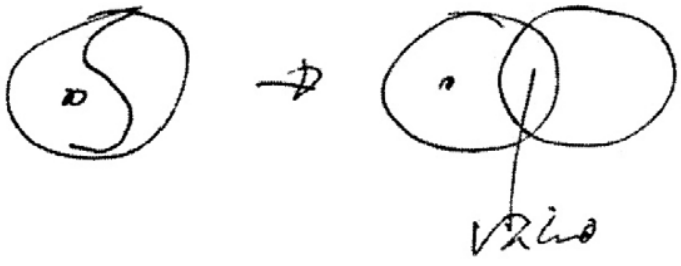

DIBUJO, (2012). Javier Seguí.

Otra referencia de Javier Seguí es la "Khôra; ámbito hueco, una especie de vacío tensado"12 o, en otras palabras: "Vacío. Khôra. Ser nada, ser puro, marco de posibilidad, ser contexto, ser cuerpo, ser condición... (a priori)."13 Javier Seguí la describe como "matriz de la aparición de las cosas", espacio que envuelve el objeto y permite que se perciba dentro del todo que está a su alrededor. "Algo hueco, vacío, donde resuenan las cosas. Son úteros vacíos, la envolvencia que contiene todo lo que puede ser; el grado cero de todo."14

La Khôra pertenece al conocimiento, "la intuición y construcción de contenedores, entramados vacíos donde quepan experiencias" ${ }^{15}$. Para Seguí, ésta se adivina en El orden del discurso, de Foucault, un libro que descubre que las palabras, al colocarlas en un discurso, cumplen ciertas condiciones para ser percibidas. Condiciones que no están formuladas, que son reglas internas que "tienen una especie de contenedor que está hueco, vacío, esperando que se llene de cosas". ${ }^{16}$ También la "gran imagen sin forma" de Françoise Julliene, evocada antes que cualquier acción importante, es algo que carece de contenido, que está vacía, y que emociona. Son todas esas emociones vividas, la reacción muscular, la alteración del cuerpo y el impulso, que surgen cuando "quitas los contenidos y quedas flotando." 17 Sensaciones que quedan vagando en una especie de Khôra, de vacío, al encontrar la belleza que se transforma en placer, sin vincularse ni al objeto de donde procede, ni al sujeto que lo ve.

Ámbitos vacíos señalados

- El paradigma.

- La analogía imaginante.

- La belleza.

2 Seguí, Dibujar, proyectar (LXVII) - Vacío, vaciar (2), 23.

3 Javier Seguí, Dibujar, proyectar (LXX) - Vacío, vaciar (5).

14 Javier Seguí, entrevistado por Maria Brito, 2 de junio, 2014, Grabación.

5 Seguí, Dibujar, proyectar (LXVII) - Vacío, vaciar (2), 23.

Javier Seguí, entrevistado por Maria Brito, 2 de junio, 2014, Grabación.

7 Seguí, 2 de junio, 2014 
- Las bellas artes - la artesanía.

- La gnosis.

- El diagrama genérico.

- La memoria.

- La acción.

- El habla.

- La negatividad.

- El éxtasis. ${ }^{18}$

Para Seguí, el paradigma es el modelo vacío relleno según unas reglas descubiertas al hacer, la "aduana donde tienes que mostrar tus credenciales para poder pasar".

Se trata de un modelo de opinión, de coincidencia colectiva en ciertas cosas con respecto a cómo tratar cierta materia. ${ }^{19}$

La analogía imaginante es una paradoja que supone una postura absolutamente vacía para conectar cosas absurdas y opuestas. $^{20}$

La gnosis, como la analogía imaginante, es tratar de entrar en contacto con todo lo externo al individuo y fundirse con ello, un estado de nirvana, místico, de quien se diluye con la nada.

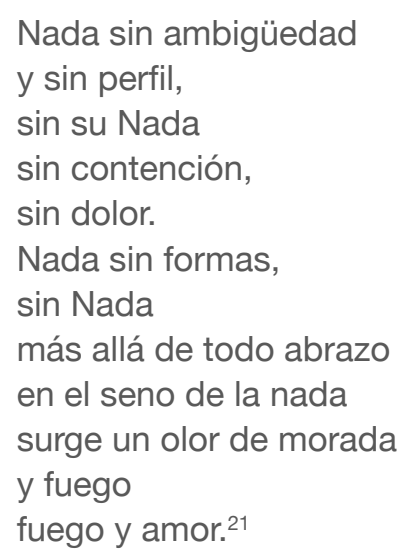

El diagrama genérico es una "reposición a posteriori del desarrollo operacional producido por una energía", una energía que "sale de lo impersonal". Algo que "tenemos dentro, que no es personal" y que se llama genio, lo que en realidad da lugar al diagrama genérico. Lo mismo sucede con el éxtasis.

La memoria es el recuerdo del hacer que no sirve de nada ha-

18 Seguí, Dibujar, proyectar (LXVII) - Vacío, vaciar (2), 30.

19 Javier Seguí, entrevistado por Maria Brito, 2 de junio, 2014, Grabación.

20 Seguí, 2 de junio, 2014

21 Juan Daniel Fullaondo, “Javier Seguí (1964-1983)," Kain 1988, 19. 
cerse, porque en la acción no se puede pensar, el individuo se entrega y rinde a ese algo impersonal que no controla.

La negatividad es la postura experimental de negar las cosas, trata de "buscar esa angulación para poder estar en contra". No por un motivo razonable o lógico, sino por verse en una situación contraria a la que se propone, una disonancia cognitiva en busca de lo que todavía no se sabe que está ahí.

Hablar del vacío, dándole forma al espacio. Estar atentos a lo que pasa y no sólo a nivel visual. Darle más importancia a los demás sentidos. Hay otras maneras de conocer, de estar, de percibir. ${ }^{22}$

El hecho de vaciar empezó haciendo una operación y luego se convirtió justamente en un fundamento casi imaginario. ${ }^{23}$

Vaciar para contemplar el vaciado, para gozar de la sinrazón, para vislumbrar el éxtasis de la nada. ${ }^{24}$

Según la American Vacuum Society (Sociedad Estadounidense del Vacío), se puede, incluso, considerar la existencia de un "grado de vacío" mensurable:

El término vacío se utiliza generalmente para denotar un volumen o región del espacio en el que la presión es significativamente inferior a 760 torr. En el sistema de medición tradicional, la presión normal se expresa en milímetros de una columna de mercurio (...). Un vacío perfecto o absoluto, que implica un espacio totalmente desprovisto de materia, es prácticamente irrealizable. Para fines prácticos, sin embargo, y de acuerdo con la definición propuesta por la American Vacuum Society, el término vacío se utiliza generalmente para denotar un espacio llenado de un gas a menos que la presión atmosférica. ${ }^{25}$

El "grado de vacío" aumenta de manera directamente proporcional a la disminución de la presión atmosférica. Pero, según su definición, el vacío absoluto es irrealizable; para ello, es necesario contar con un espacio completamente desprovisto de materia.

El astrofísico británico Stephen Hawking explica esta cuestión

\footnotetext{
22 "Danilo Versas Godoy. Arquitecto 1949/2007," Ordem dos Arquitectos Portugal,2008,

2 de febrero de 2014, http://issuu.com/haguilarj/docs/expo_danilo.

23 Javier Seguí, entrevistado por Maria Brito, 6 de julio, 2015, Grabación.

24 Javier Seguí, Dibujar, proyectar (LXVIII) - Vacío, vaciar (3) (Madrid: Instituto Juan Herrera de la Escuela de Arquitectura de Madrid, 2014), 21.

25 Dorothy M. Hoffman, Bawa Singh, and John H. Tomas, "Vacuum Nomenclature and

Definitions," en Handbook of Science and Technology (USA: Academic Press, 1998), 3.
} 
de una manera totalmente novedosa, afirmando que el "vacío" es el origen y el posible fin del cosmos:

Observaciones recientes del campo de Higgs han suscitado la posibilidad de que el campo podría no estar en el estado más bajo de energía. Si ése fuera el caso, el campo estaría en un estado de "falso vacío". Podría decaer a un vacío verdadero por fluctuaciones cuánticas, dando lugar a una burbuja de vacío verdadero, que se expandiría a la velocidad de la luz. No lo veríamos acercándose, pero sí nos golpearía, nos destruiría por completo. ${ }^{26}$

La teoría del bosón de Higgs, anteriormente denominada "la partícula de Dios", habla de un vacío que tiene la capacidad de destruir el universo al completo, porque, sujeto a elevadísimos niveles de energía, sus partículas se volverían inestables y, como defiende Hawking, se produciría un "decaimiento de vacío catastrófico". ${ }^{27}$ Al respecto, Javier Seguí dice que "del bosón lo sabemos todo menos si existe -¿Como Dios?-:"28 "El vacío -estado de mínima energía- está lleno de una sustancia -el campo de Higgs- cuyas vibraciones son los bosones. (...) La interacción consigo mismo, el bosón, implica que el vacío y la nada no sean lo mismo."29

Sin embargo, con este descubrimiento anticipado en 1964, el vacío adquiere una nueva dimensión que erradica cualquier tentativa de considerarlo un delirio metafísico. Por ese motivo, el advenimiento del Apocalipsis, hecho que también Javier Seguí defiende, gana cada vez más adeptos. Con esta teoría, el vacío cobra una nueva dimensión: la idea primordial de que éste es un campo estático e inerte se ve ahora desde otro prisma.

El vacío es un campo vibrante donde actúan las partículas. El bosón es la unidad básica del vacío (del vacío de Higgs). (...) Vacío. Campo vibrante... generado por el choque energético de las partículas... vacío campo de choque.... Que permite la dinamicidad, genera masa... (y la disuelve). ${ }^{30}$

Este "vacío" científico abre un nuevo universo en las artes, que ya intuyen su identidad y que, a lo largo del proceso, tratan de

\footnotetext{
26 José Manuel Nieves, "Stephen Hawking: "El vacío de Higgs podría destruir el universo", Abc.es, 7 de mayo de 2015, http://www.abc.es/ciencia/20140923/abci-higgs -hawking-destruir-universo-201409232041.html.

27 Jonathan Leake, "Hawking: God Particle Could Destroy Universe," The Sunday Times, 7 de mayo de 2015 ,

http://www.thesundaytimes.co.uk/sto/news/uk_news/Science/article1455968.ece?CM$\mathrm{P}=\mathrm{OTH}$-gnws-standard-2014_09_06.

28 Seguí, Dibujar, proyectar (LXVII) - Vacío, vaciar (2), 32

29 Seguí, Dibujar, proyectar (LXVII) - Vacío, vaciar (2), 32.

30 Seguí, Dibujar, Proyectar (LXVII) - Vacío, vaciar (2), 32.
} 
dotarlo de significado.

El arte ya no busca la "plena realización de su arte", sino ese silencio que no se puede leer y que no busca explicación. Dibujar, cuenta Seguí, nace de un juego de colisiones y desplazamientos fruto de la liberación del cuerpo.

Prada plantea, incluso, un vínculo del vacío del artista con su cuerpo:

Por un lado, mantiene, aunque congelado, el movimiento del brazo del pintor. Por otro, permite que el cuerpo del hombre se proyecte en su interior. (...) Esta doble vinculación entre el lienzo y el cuerpo permite que unos pocos elementos, unos simples brochazos, activen la parte no pintada del cuadro. ${ }^{31}$

Seguí defiende que el vacío de una obra puede, de alguna manera, representar el silencio del cuerpo delante de la obra, la reflexión evocativa de un gesto contenido por su ausencia. Con esta teoría, resulta inevitable no mencionar la caligrafía japonesa, que, en cierto modo, representa esta cuestión:
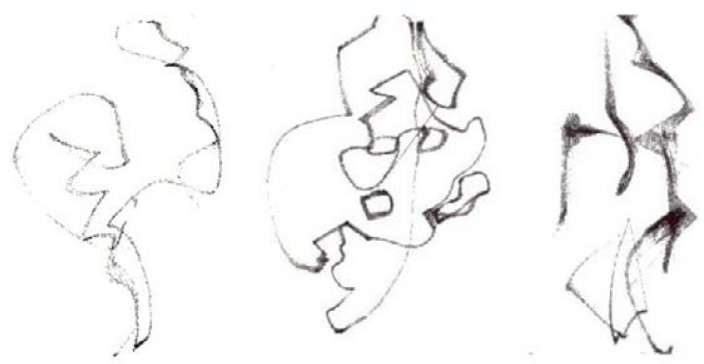

DIBUJOS, (2009). Javier Seguí.
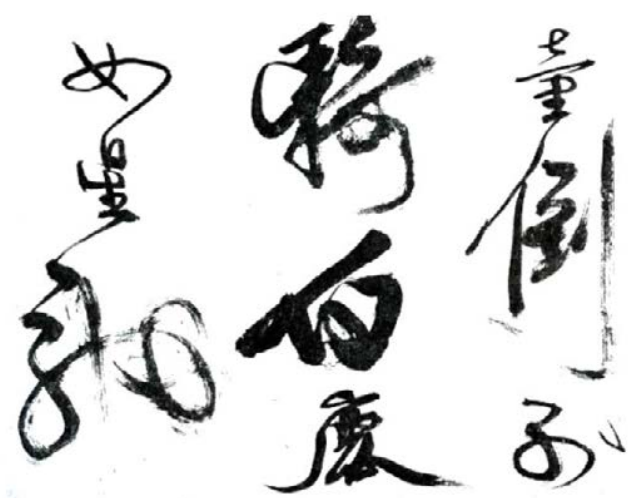

CALIGRAFÍA JAPONESA.

31 Manuel de Prada, "Componer con vacío," 64. 
El panorama actual del arte invita al vacío; ese lugar que no dice nada y, por tanto, lo dice todo; un silencio visual que concede un respiro para que el pensamiento descanse.

El actual régimen estético busca el vacío.

Lugar donde todo queda por hacer.

Vacío de un arte al que ningún límite amenaza, para el que todo es posible y nada necesario. Confrontación entre lo visible y lo decible.

Si el arte importa, es porque podemos ver que sus espacios cambian y, con ellos, los tipos de percepciones y pensamiento que pugnan por su propiedad. ${ }^{32}$

En el ámbito artístico se encuentran artistas que "dan más sentido" al vacío: Henry Moore y Chillida, que, por fuerza, se relacionan directamente con Oteiza y Palazuelo. Este cuarteto de artistas, referencia de Javier Seguí -y unidos por el estudio de la arquitectura- encuentran en el vacío la poética de su obra.

Para Oteiza, el vacío, asociado sobre todo al crómlech vasco, no existe sin un referente antropológico y espacial. Éste se ocupa de la "desocupación metafísica del vacío":33

Ya hemos explicado que el vasco desde el crómlech tiene una sensibilidad receptiva, que no llena los espacios vacíos, que no es decorador, que rechaza la expresión ocupante del espacio, la parlante, la expresión que acentúa la voz, la que rompe el silencio. "No pone la boina en medio": su estilo, que se identifica con la naturaleza, es irregular, inestable, no tiene simetría. ${ }^{34}$

Oteiza crea sus esculturas de movimientos vaciando la materia. A finales de los años cincuenta, en sus últimas obras, tituladas Cajas vacías y cajas metafísicas, el escultor pretende despojar la materia hasta vaciarla. Con ella intenta enseñar el lado oculto de la materia, que hace presente en su ausencia: "Cualquier espacio vacío (estéticamente desocupado) es espiritualmente receptivo. Pero el hombre ha de estar preparado para servirse espiritualmente de él, para habitarlo (espiritualmente)."35

Para Oteiza, la desmaterialización es la única forma de materia-

\footnotetext{
32 Seguí, Dibujar, proyectar (LXVIII) - Vacío, vaciar (3), 20.

33 Jorge Oteiza, Quousque Tandem...! Ensayo de interpretación estética del alma vasca., trad. Pello Zabaleta Kortaberria, Amador Vega y Jon Echevarria Plazoala ed. (San Sebastian: Fundación Museo Jorge Oteiza. , 2007), 43.

34 Oteiza, Quousque Tandem...! Ensayo de interpretación estética del alma vasca, 242.

35 Oteiza, Quousque Tandem.! Ensayo De Interpretación Estética Del Alma Vasca, 343.
} 
lizar sus ideas. Reducir la materia al mínimo hasta anularla. En su Homenaje a Mallarmé, expresa con sus cajas vacías ortogonales, donde el espacio vacío aparece flanqueado por planos, lo mismo que ya sugiriera Mallarmé cuando hace que el peso del texto poético descanse en los vacíos del papel. Su objetivo es claro: "abandonar el arte tras vaciarlo de materia y dejarlo sin objeto para pasar a la vida" ${ }^{36}$
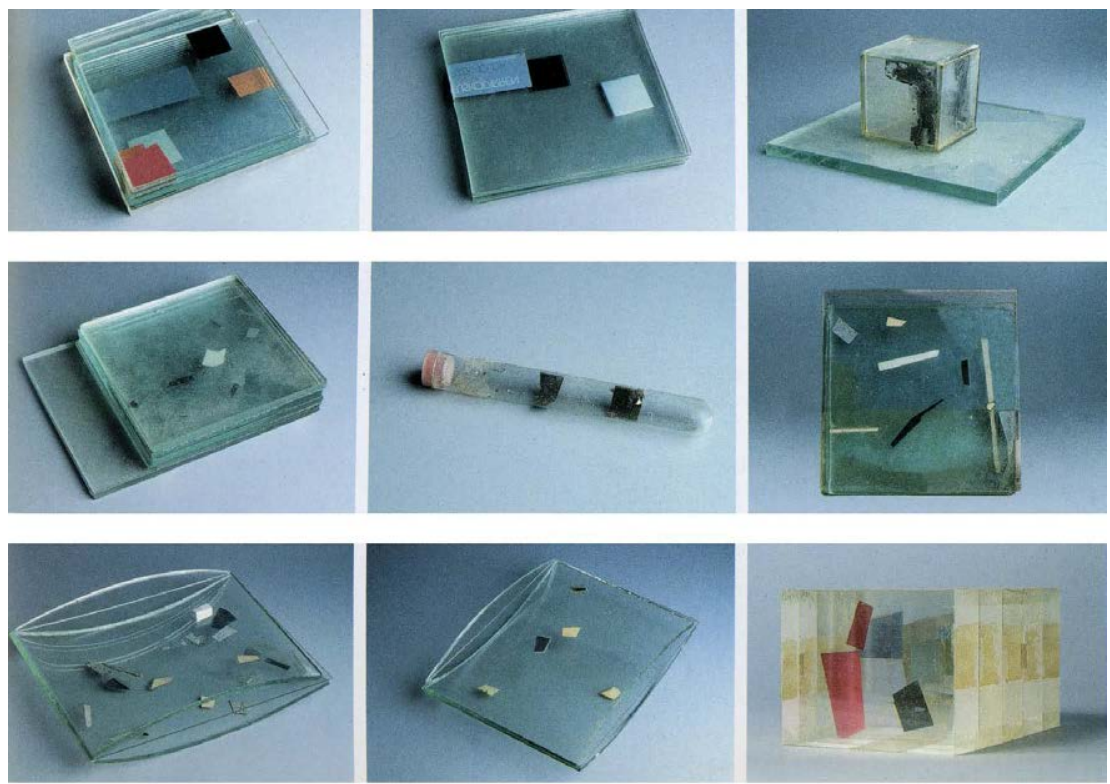

PARED LUZ, (1956) - Oteiza. Placas de cristal superpuestas, tizas y cintas adhesivas. Sobre estas obras Javier Seguí relata: "Estaba en una exposición de él. De alguna manera está en negativo a lo que estábamos haciendo nosotros. Nuestro ejercicio era hacer un tejido de viviendas compactísimo, y una vez que tienes ese tejido le vas haciendo agujeros, le vas quitando cachos. Resulta que aquí el tejido es el vidrio y lo que vas colocando aquí son los vacíos. Lo tienes que ver en negativo. Al revés. El transpa-

rente opaco y lo opaco transparente. Al hacerlo así, te sale una ciudad radical." ${ }^{37}$

Oteiza ejerce una influencia primordial en Javier Seguí, especialmente en su nueva manera de abordar el vacío/lleno, en busca de un nuevo sentido a esta manera de construir mentalmente sus dibujos/diagramas.

\author{
Si lo vaciado, \\ lo que deja un rastro de contenido ausente, \\ lo ausentado, \\ la ausencia, \\ lo lleno de basura, de nada. \\ Vaciar de significación es llenar algo de insignificancia. ${ }^{38}$
}

\footnotetext{
36 Carlos Marínez Gorriarán, Jorge Oteiza hacedor de vacíos (Madrid: Marcial Pon,

Ediciones de Historia, 2011), 232.

37 Seguí, 2 de junio, 2014.

38 Javier Seguí, Dibujar, proyectar (LXXI) - Vacío. Oquedad. Reverso. (Madrid: Instituto

Juan Herrera de la Escuela de Arquitectura de Madrid, 2014).
} 

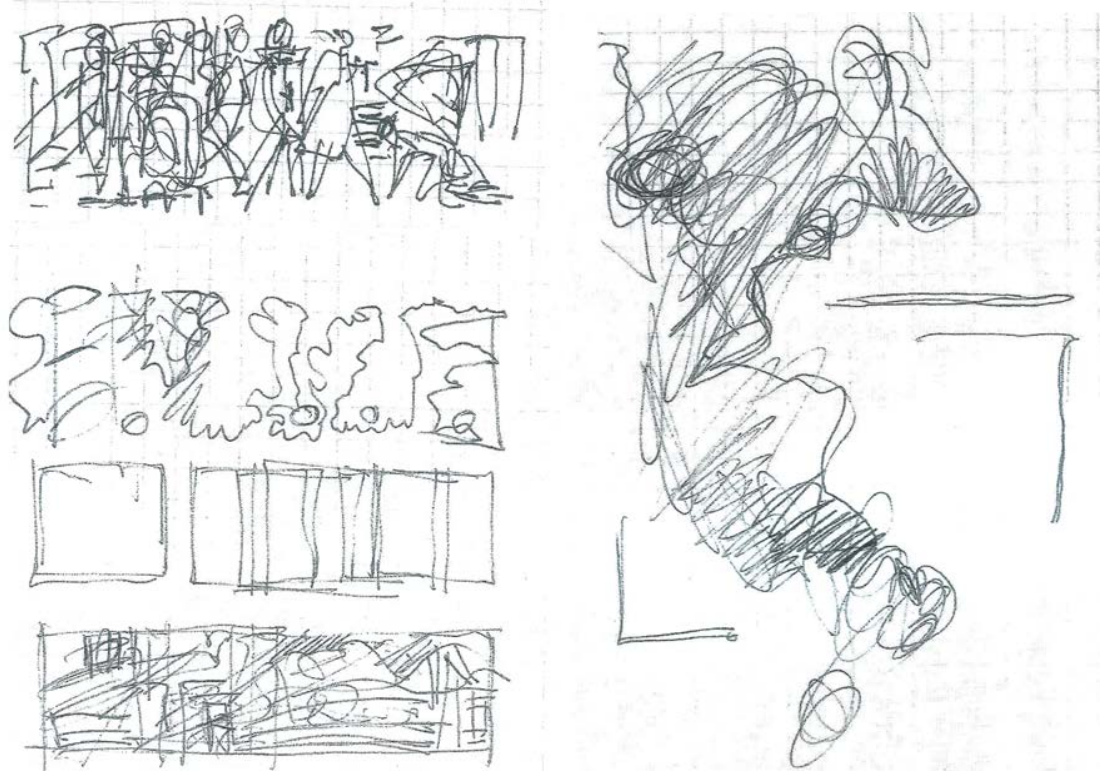

LLENAR VACIAR, (2012). Javier Seguí.

\section{En relación a Palazuelo, Seguí comenta:}

El vacío contiene energía y movimiento y es básicamente creativo en el sentido que hemos dicho que la "visión interior creativa" procede de aquella fuente total que se halla más allá del nivel material. (...) El espacio que creemos vacío es un "inmenso mar de energías" (David Bohm). En aquel abismo multidimensional la interacción es constante entre los dinamismos de lo material inconsciente y los dinamismos de la materia. Las formas aparecen y desaparecen en el seno de aquel mar sin límites, lo mismo que lo hacen las partículas "subatómicas" descubiertas no hace mucho por los físicos "pasándose unas a otras" a través de "metamorfosis", como lo hacen las sucesivas formas de las mariposas. ${ }^{39}$

Palazuelo, que a diferencia de Oteiza, es gran amigo de Chilli$\mathrm{da},{ }^{40}$ coincide en su manera de entender el vacío como dimensión material y opaca, decisiva en la definición de la forma. Para Seguí: "El ser es un vacío... un ámbito, una matriz, ahuecada... dispuesta a matizar, a ordenar... a admitir/excluir posibles... contenidos." 41

Oteiza y Palazuelo dejan una huella imborrable en el imagina-

39 Carmen Bonell,La geometría y la vida. antología de Palazuelo.(Murcia: CENDEAC),187.

40 La guerra de Oteiza con Chillida es famosa. Durante casi treinta años Oteiza acusa a Chillida de plagio, una polémica que cuenta con admiradores y defensores en ambos bandos. Oteiza, siempre controvertido, asume un papel bastante político en este enfrentamiento, llegando a discutir, incluso, las esculturas de Henry Moore instaladas en Guernica (Vizcaya). Oteiza lucha por situarse en la vanguardia del arte vasco.

41 Seguí, Dibujar, proyectar (LXVIII) - Vacío, vaciar (3), 24. 
rio de Javier Seguí, en su manera de entender el dibujo y, por consiguiente, en la manera de encontrarse con la arquitectura. También para Seguí, inmerso en este mundo, el dibujo "funciona por el vacío en que circulan los alientos." 42 El vacío es lo que vive frente a lo lleno, lo estático. Es el motor de las cosas, el impulso de luz que espera, pero que representa en su plenitud el inicio, el origen.

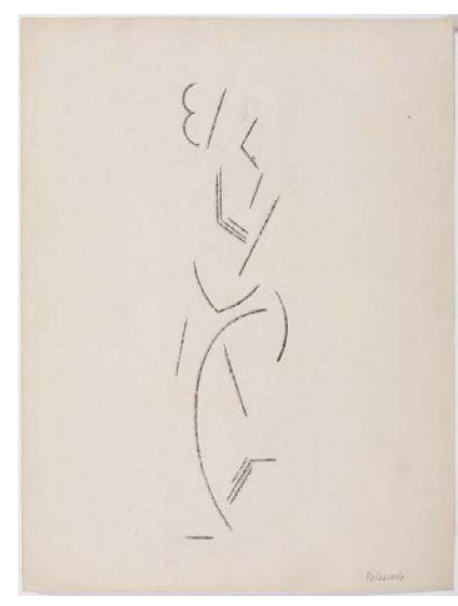

SIN TITULO, (1950). Palazuelo.

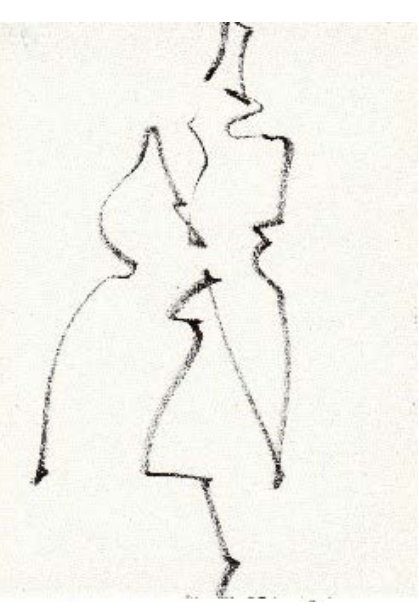

CUADERNO 06, (2012). Javier Seguí.

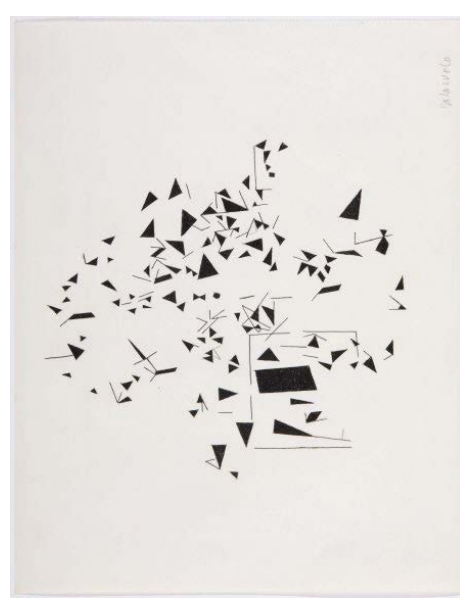

COSAS OLVIDADASIII (1952).

Pablo Palazuelo.

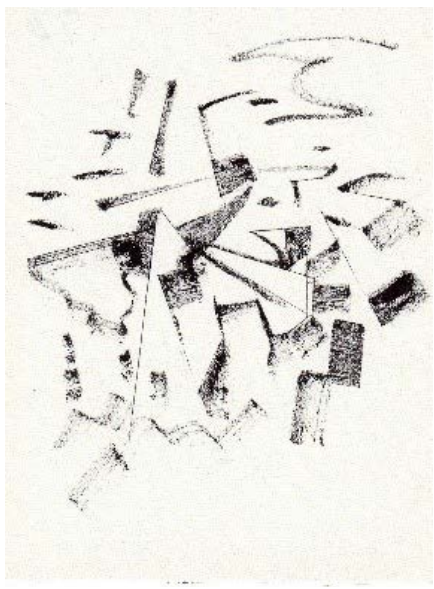

CUADERNO 06, (2012). Javier Seguí.

Si se observan detenidamente los dibujos de Seguí, es evidente que la forma de abordar el lienzo es completamente distinta. En el primer dibujo, la representación impulsa a la línea a ocupar el vacío del lienzo, pero en el segundo es el vacío el que gana protagonismo, y la mancha sólo es un artificio para dar luz a lo que queda por dibujar. 


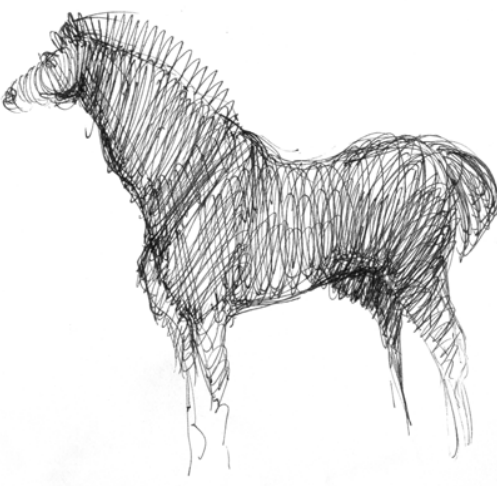

GOTAS DE SOLEDAD, (1965-1977). Javier Seguí.

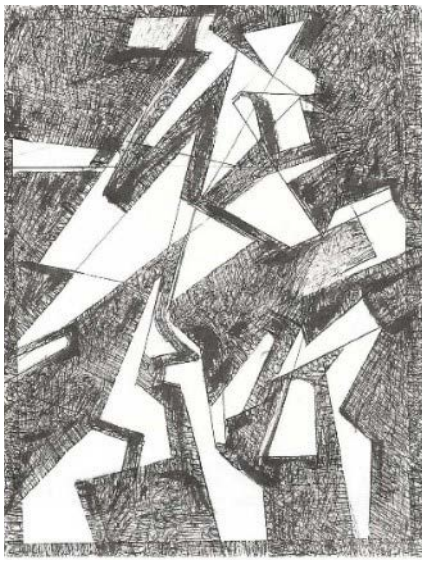

CUADERNO 06, (2014). Javier Seguí.

Los vacíos del dibujar y de los dibujos son el residuo blanco del vaciar negro que es el trazar. El blanco del papel es el lleno que el trazar dibujando-escribiendo deja como testimonio de la erosión producida al trazar-quitar. El blanco del papel se transforma en contexto lleno de la escisión separación que avanza trazando, haciendo, el vaciar del lleno ya vacío. ${ }^{43}$
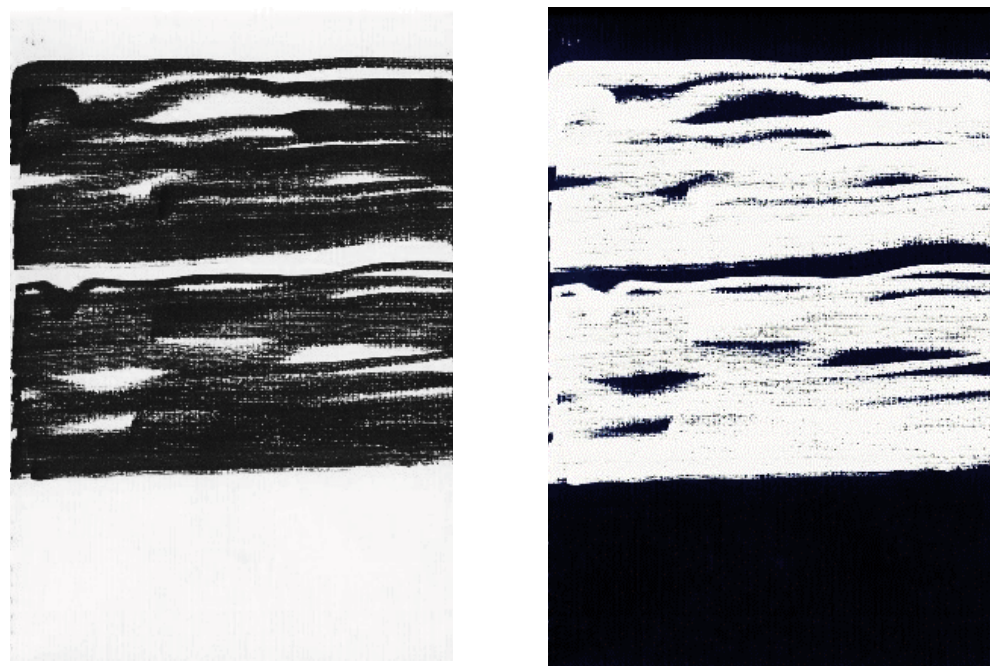

OSCURIDAD Y SOMBRA, (después de 2000). Javier Seguí. A la derecha el mismo cuadro de la izquierda, pero con la luz invertida. ${ }^{44}$

\footnotetext{
43 Seguí, Dibujar, proyectar (LXVII) - Vacío, vaciar (2), 15.

44 Si se analizan estos dos dibujos de Javier Seguí, se repara en que, con una inversión del color, surge una nueva manera de asaltar el blanco del lienzo. Éste ya no es un vacío al que se van agregando manchas, sino que es un lleno del que se van restando trozos o, como él mismo diría, el "reverso del dibujo es su entidad inversa, la huella de lo no alterado por él, la estructura de lo inalcanzado por la acción dibujadora." En Seguí, Dibujar, proyectar (LXXI) - Vacío. Oquedad. Reverso., 28.
} 
El dibujo ya no desea partir de un blanco vacío, sino hacer que el dibujo aparezca cuando le son retirados trozos de negro. Como afirma Seguí: "Los dibujos son como frases vistas de perfil, son acumulaciones de estadios sucesivos de trazos sobre un marco cosmos vaciado por el vaciar negro (o de color) sobre el lleno blanco." 45

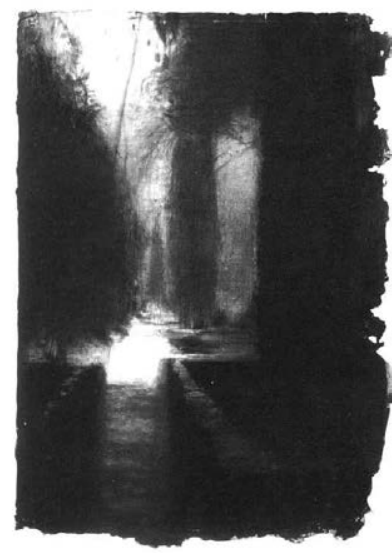

ALCAZAR DE SEVILLA,

(1988). Fernández.

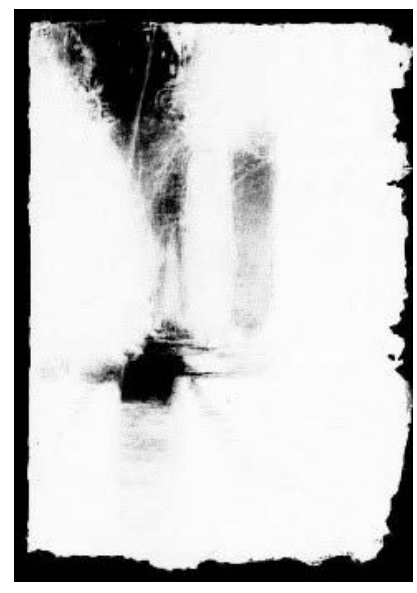

ALCAZAR DE SEVILLA con luz invertida, (1988). Fernández.

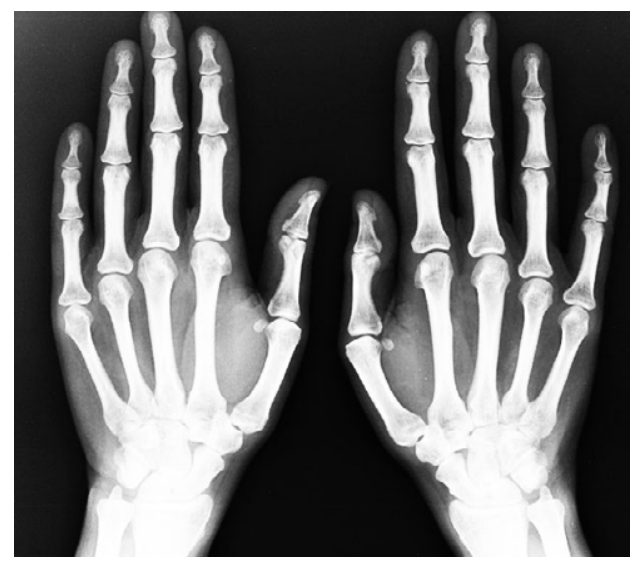

RADIOGRAFIA DE MANOS.

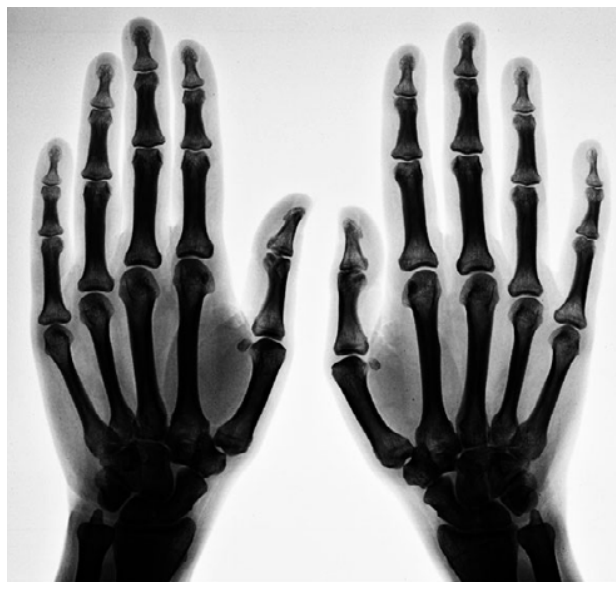

RADIOGRAFIA DE MANOS con luz invertida.

También el escultor Henry Moore, que surge en los años treinta como figura esencial dentro de este nuevo panorama artístico, crea una serie de esculturas en las que el vacío es el protagonista. Para el artista, tanto lo lleno como el vacío son complementos de una misma unidad. Como explica Manuel de Prada: "Las características esculturas de Moore, orgánicas y naturalistas, surgieron de una revelación: cuando hacemos un agujero en un 
sólido, la tridimensionalidad y la unidad física y perceptiva del sólido se acentúan."46

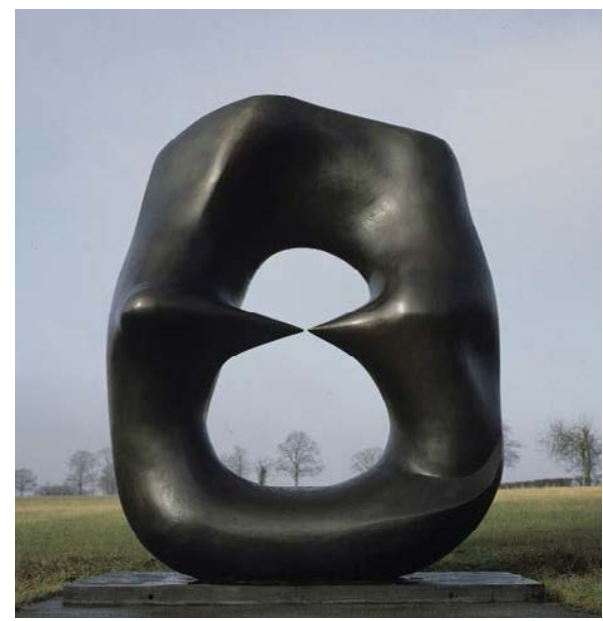

ÓVALO CON PUNTAS, (1968-1970). Henry Moore. Edición en bronce de $6 \times 1$. Una vez más queda clara la intención del escultor de dejar patente que la forma exterior es la que protege y encierra la interior.

En los años cincuenta, Chillida, bajo la influencia oriental heideggeriana, comienza su recorrido destinado a descubrir y desvelar el vacío en la obra de arte. Apelando a su dualidad gestáltica, el vacío pierde su carácter de oquedad, de inmaterialidad, y pasa a ser contemplado como espacio vivencial. Manuel de Prada dice al respecto: "No hablo del espacio situado fuera de la forma, que rodea al volumen y en el que viven las formas, sino del espacio generado por las mismas." 47

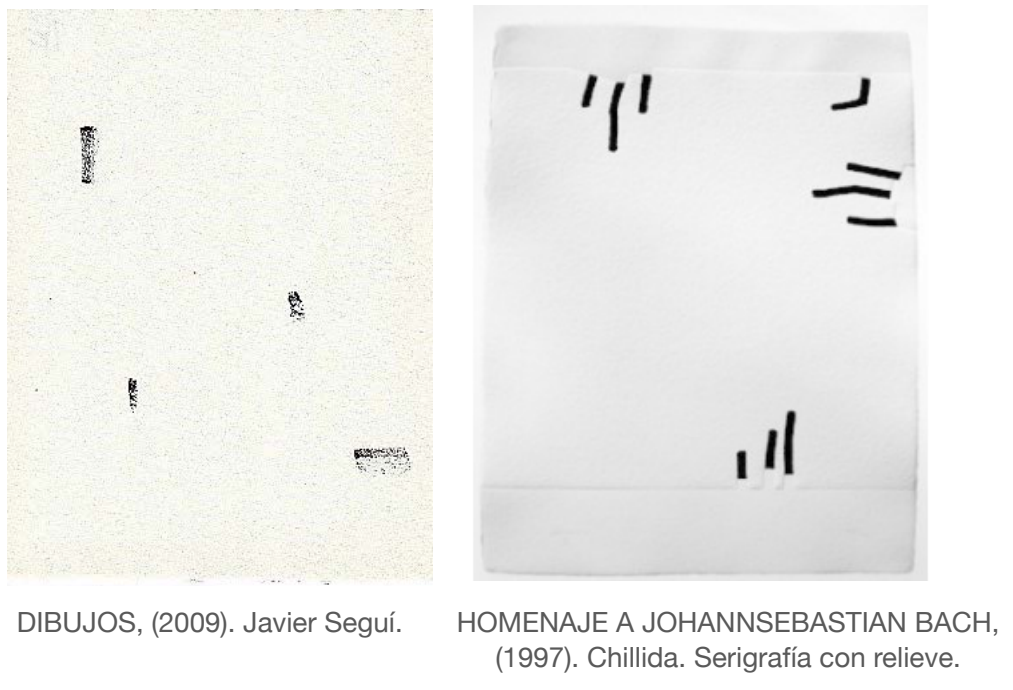

46 Prada, "Componer con vacío," 62.

47 Prada, "Componer con vacío," 63. 
El vacío de Chillida es "un vacío metafísico, una construcción intelectual que delimita una configuración hacia adentro y un limitar hacia afuera. El vacío queda perfectamente cualificado. Algo así debemos preguntarnos en la arquitectura." 48

El vacío de sus obras se acomoda al espacio arquitectónico cuando éste queda libre de la forma y le proporciona una calidad narrativa. Se puede decir que la arquitectura es vacío, su forma ordena el exterior.

En primer lugar, configurar con vacío los espacios habitables. Los arquitectos estamos acostumbrados a configurar los edificios partiendo del sólido. Sin embargo, mientras la materia sólo puede sentirse, el vacío se experimenta y se vive.

En segundo lugar, atender a la unidad de la configuración de los vacíos comparando las configuraciones que se obtienen cuando el objeto se secciona según las tres dimensiones del espacio.

En tercer lugar, procurar el equilibrio entre los distintos "momentos de configuración" (euritmia, proporción y dirección) de acuerdo a una "idea" de "unidad en la diversidad" y "quietud en el movimiento". 49

Hablar del vacío en arquitectura significa entenderlo como materia, y no como algo sobrante. El vacío y la materia pertenecen a una misma composición, cuyo resultado es la unidad. Como afirma Seguí: "Sustraer es quitar; disolver, re-traer, es tratar de alcanzar lo vaciable, que es: indecible, indiscernible, etc."

El vacío no es lo que sobra de la forma, sino la "materia" compacta que envuelve los edificios. Son muchos los ejemplos que se pueden encontrar a este respecto, pero cabe destacar el paradigmático caso d e la ciudad subterránea de Derinkuyu ${ }^{50}$, en la región turca de Capadocia; es la ciudad donde el vacío surge como el gran intérprete de su estructura y que parte de una masa única de la se van extrayendo trozos.

\footnotetext{
48 Miquel Lacasta, "El vacío cosificado - Chillida, Oteiza, Palazuelo, arquitectos.," Axonométrica,11 de mayo de 2015, https://axonometrica.wordpress.com/2012/03/04/el-vacio-cosificado-chillida-oteiza-palazuelo-arquitectos/.

49 Manuel de Prada, "Componer con vacío," 83.

50 Ciudad excavada por los hititas alrededor del año 1400 a.C. Se trata de una ciudad completamente subterránea de Anatolia Central (Turquía), totalmente esculpida en una única unidad geológica. Esta ciudad sirve de refugio a los cristianos y también a los griegos. Hasta el momento, se han descubierto veinte niveles subterráneos con una profundidad total de ochenta y cinco metros. Cuenta con establos, comedores, cuartos, iglesias y escuelas. Contiene quince mil conductos de ventilación y puede albergar a más de diez mil personas.
} 


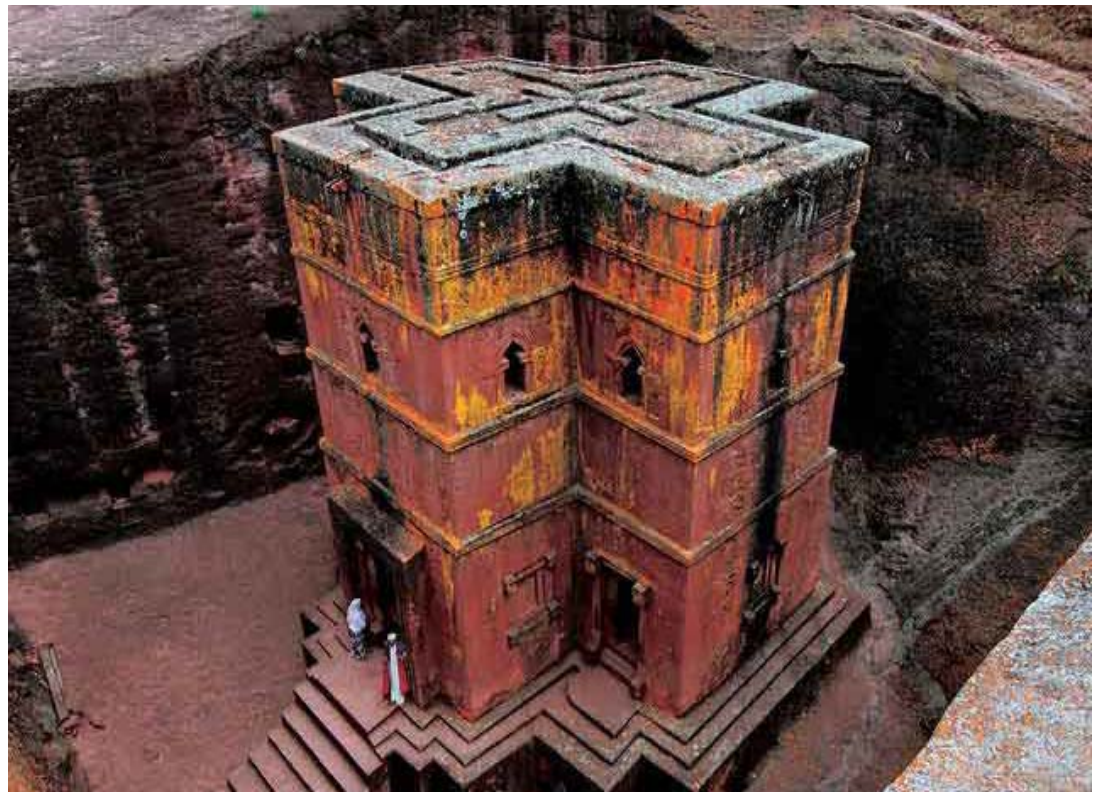

IGLESIA BET GHIORGIS, Lalibela, Etiopia, (Siglo XII - XIII). Iglesia de arquitectura rupestre tallada en roca basáltica de color rojizo en la ciudad monástica de Lalibela.

En este caso son los vacíos los que interpretan el espacio, a semejanza de Argia, ${ }^{51}$ la ciudad de Italo Calvino en la que la tierra, en vez del aire, cubre por completo las calles. Las habitaciones están llenas de arcilla hasta el techo y sobre los tejados de las casas hay estratos de terreno:

Lo que hace a Argia diferente de las otras ciudades es que en vez de aire tiene tierra. La tierra cubre completamente las calles, las habitaciones están llenas de arcilla hasta el cielo raso, sobre las escaleras se apoya otra escalera en negativo, encima de los techos de las casas pesan estratos de terreno rocoso como cielos con nubes. Si los habitantes pueden dar vueltas por la ciudad ensanchando las galerías de los gusanos y las fisuras por las que se insinúan las raíces, no lo sabemos: la humedad demuele los cuerpos y les deja pocas fuerzas; conviene que se queden quietos y tendidos, tan oscuro

\footnotetext{
51 También la ciudad de Eusapia se asemeja a esta descripción de ciudad excavada: "No hay ciudad más propensa que Eusapia a gozar d e la vida y a huir de los afanes. Y para que el salto de la vida a la muerte sea menos brusco, los habitantes han construido una copia idéntica de su ciudad bajo tierra. Esos cadáveres,

desecados de manera que no quede sino el esqueleto revestido de piel amarilla, son llevados allá abajo para seguir con las ocupaciones de antes. (...) Sin embargo, todos los comercios y oficios de la Eusapia de los vivos funcionan bajo tierra, o por lo menos aquellos que los vivos han desempeñado con más satisfacción que fastidio. (...) La Eusapia de los vivos se ha puesto a copiar su copia subterránea. Dicen que esto no ocurre sólo ahora: en realidad habrían sido los muertos quienes construyeron la Eusapia de arriba a semejanza de su ciudad. Dicen que en las dos ciudades gemelas no hay ya modo de saber cuáles son los vivos y cuáles los muertos." En, Italo Calvino, As Cidades Invisíveis (Lisboa: Editorial Teorema, 1990), 111.
} 
está. De Argia, desde aquí arriba, no se ve nada; hay quien dice: -Está allá abajo- y no queda sino creerlo; los lugares están desiertos. De noche, apoyando la oreja en el suelo, a veces se oye una puerta que golpea. ${ }^{52}$

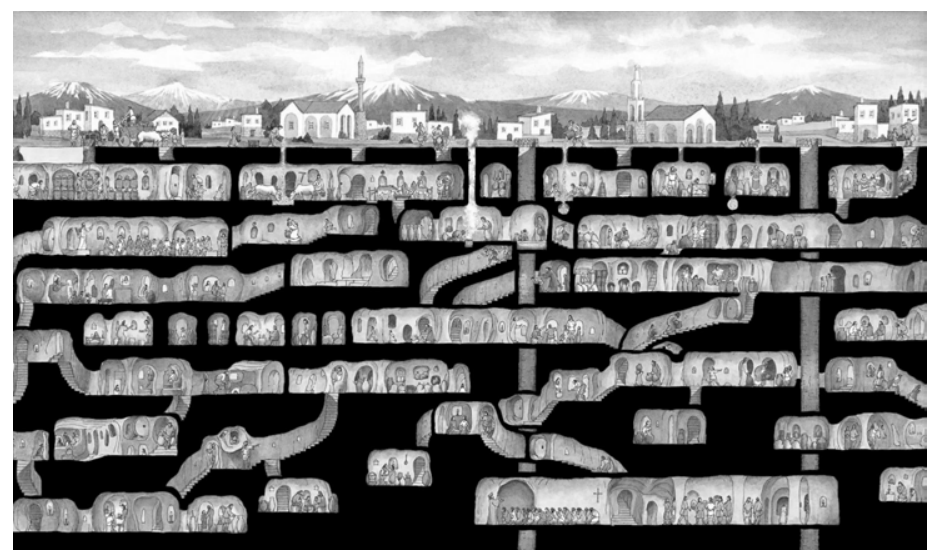

DERINKUYU, Capadoccia, Turquia, (1400 a.C).

También en la India abundan los "templos cueva", símbolos arquitectónicos que se sustraen del material; se abren cavidades en vez de erigir la materia sobre la materia, quedando patente que "en ellos lo que se percibe es la cavidad, mientras que la roca sólida que la rodea es el fondo neutro que se dejó sin tratar." 53
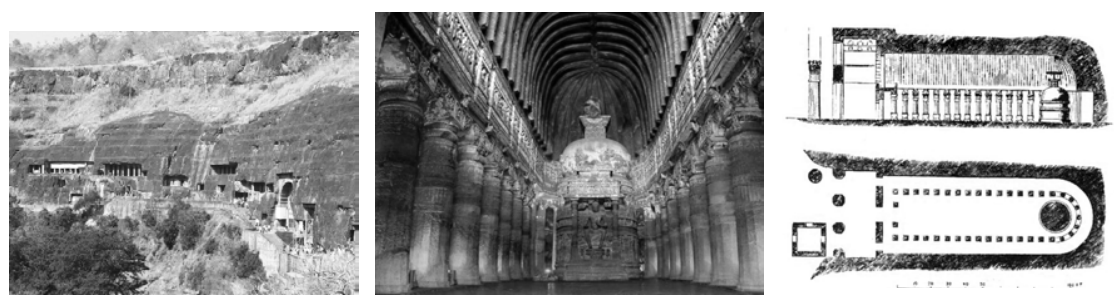

CUEVAS DE AJANTA, Maharashtra, India, (siglo II a.C. - siglo I a.C.). Conjunto de templosexcavados por monjes budistas en el interior de una roca.

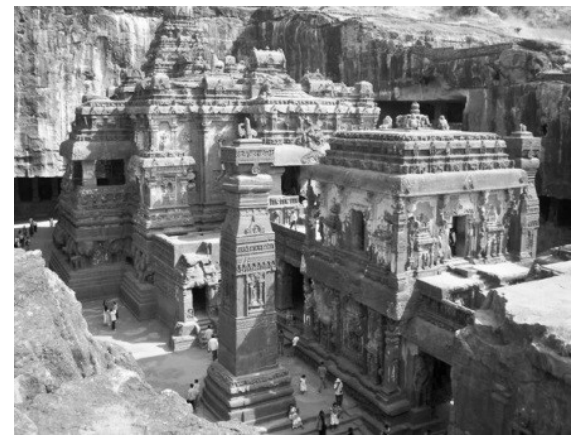

CUEVAS DE ELLORA, Maharashrta, India, (siglos $\mathrm{V}$ y X).

52 Seguí, Dibujar, proyectar (LXVIII) - Vacío, Vaciar (3), 129.

53 Steen Eiler Rasmussen, La experiencia de la arquitectura. Sobre la percepción de nuestro entorno., trad. Carolina Ruiz (Barcelona: Editoria Reverté, 2007). 
Javier Seguí habla del vacío como una interfaz. Si se hace desde el exterior, es el espacio para dibujar, para crear. Si se crea desde el interior, desde el sentimiento, se llama la fuente del alma. El vacío está justo ahí, entre el exterior y el interior.

Sin embargo, para Cage "no existe lo que llamamos silencio" y Turrell, por su parte, afirma que "nunca no hay luz". ${ }^{54}$ Es decir que, en realidad, el espacio vacío no existe; todo resuena.

El silencio es la suspensión del sentido, o su grado cero... umbral de la escucha pura. (...) Silencio es inmersión, abrazo, de lo sonoro suspendido, de lo sensible envolvente... olvido en la presencia de la ausencia. (...) El silencio se vincula/relaciona con el vacío, la extrañeza, lo inimaginable, la no lugaridad... El asombro... lo blanco, lo no privado inexplorado. ${ }^{55}$

Siguiendo las huellas de Prada, Cornelis van de Ven afirma que "el contenido intangible de la forma arquitectónica, el vacío interior, es lo que verdaderamente impulsa la arquitectura." 56

Por su parte, Schmarsow llama arquitectura a ese "espacio tridimensional vacío que el ser humano configura alrededor de su cuerpo". ${ }^{57} Y$ es que, en arquitectura, el espacio vacío es lo que, en efecto, se puede habitar. En el comienzo de los años veinte y con la Teoría de la Gestalt, la percepción de este vacío pasa a desempeñar un papel protagonista en la composición artística. El vacío, que en el pasado no es más que el espacio que sobra de la forma, se convierte ahora en el otro protagonista de la obra.

(...) en la mente de un arquitecto que proyecta un edificio. Tras esbozar someramente las formas principales, les va añadiendo detalles como si fuesen brotes y espinas que saliesen de un tallo. (...) En vez de dejar que la imaginación trabaje con formas estructurales, con los sólidos de un edificio, el arquitecto puede trabajar con el espacio vacío -la cavidadque queda entrepruebasesos sólidos, y considerar que ese verdadero significado de la arquitectura es la configuración de ese espacio. ${ }^{58}$

Le Corbusier, en sus Cuatro composiciones para erigir una vivienda (1929), decide representar en negro los espacios interiores libres y en blanco los espacios ocupados. Esta decisión, aparentemente aleatoria, origina una manera distinta de percibir el vacío.

\footnotetext{
54 Javier Seguí, Dibujar, proyectar (LXIX) - Vacío, vaciar (4), 6.

55 Seguí, Dibujar, proyectar (LXIX) - Vacío, vaciar (4), 19.

56 Manuel de Prada, "Componer con vacío," 57.

57 Prada, "Componer con vacío," 57.

58 Rasmussen, La experiencia de la arquitectura. Sobre la percepción de nuestro entor-

no, 41-42.
} 


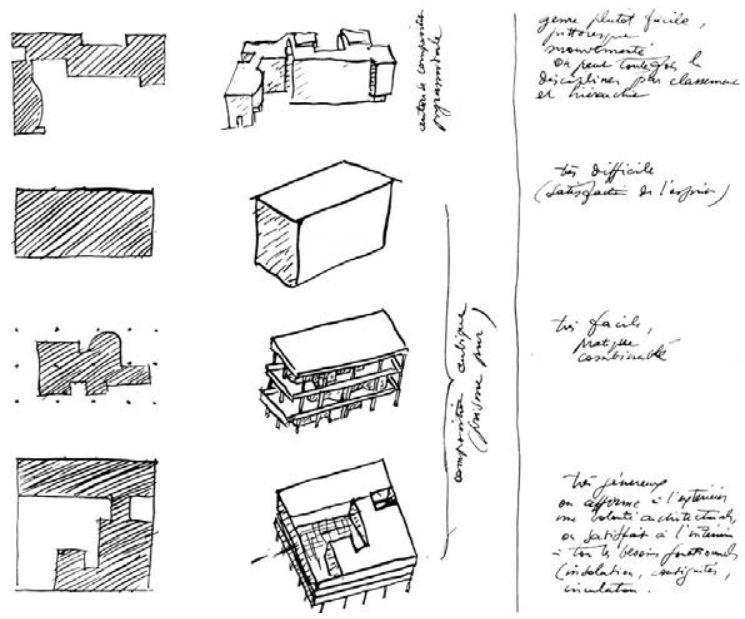

CUATRO COMPOSICIONES, (1929). Le Corbusier.

El análisis de este gráfico basta para entender la fuerza de la dualidad lleno/vacío, figura/fondo. En estos estudios se hace patente que las partes no deben ser vistas por separado, sino como unidad de la misma configuración. Este ejercicio gráfico es reproducido también por Robert Krier cuando dibuja las obras de Paladio según un tratamiento endotópico.

En este sentido, es interesante constatar la paradoja que hace que se entienda la figura/fondo, lo vacío y lo lleno, la materia y la no materia; mediante el simple hecho de cambiar la manera de percibir el soporte.
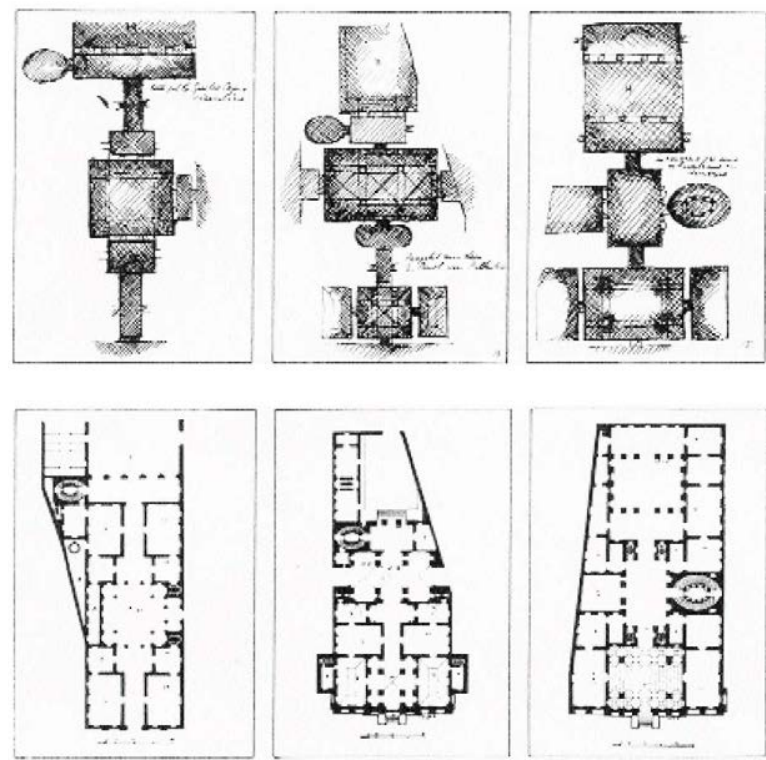

PLANTA DE TRES PALACIOS DE PALLADIO, (1988).

Dibujos de Robert Krier según tratamiento endotópico de las plantas. 
Este truco gráfico, usado en primer lugar por Le Corbusier, lo recuperan Klee y Loos. Sobre ello, Prada afirma que "el hecho de que pongan en primer plano la doble configuración de masas y vacíos nos permite interpretarlas como un paso importante hacia la activación del vacío en el arte y la arquitectura."59

La cuestión de figura/fondo, íntimamente relacionada con la percepción, impulsa la aparición de numerosos estudios, incluidos los de personalidad. El más conocido, de Hermann Rorschach, ${ }^{60}$ tiene por objeto percibir el poder de la imaginación a través de láminas con ambiguas manchas. El análisis depende de la relación del individuo con el dibujo abstracto. A efectos de esta investigación, resulta interesante saber que uno de los criterios para definir la personalidad trata, precisamente, de entender cómo establece el sujeto la relación de la figura con el fondo: si, por un lado, el blanco no era un simple vacío, sino que lo incluye en la lectura general de la mancha/composición; o si, por otro lado, se efectúa la inversión de figura-fondo y el blanco se considera la figura. ${ }^{61}$

Javier Seguí, motivado por el proyectar gestáltico, también incluye este tipo de ejercicios en su metodología del dibujar: "Los test proyectivos se desarrollan a partir de la advertencia de estas proyecciones. Nosotros estudiamos en profundidad los trabajos de Rorschach y de Wartegg en un artículo titulado 'Relación entre Rorschach, Wartegg y la expresión artística', en Ordenadores en el arte. Madrid 1969."62

\footnotetext{
59 Prada, "Componer con vacío," 62.

60 A través de diez láminas manchadas de tinta, se evalúa la personalidad del paciente preguntándole lo que ve en cada una de ellas. Utilizando criterios tales como tiempo de lectura, posición, localización, forma, movimiento, color y categoría, el psiquiatra y psicoanalista intenta evaluar la personalidad y el funcionamiento del sujeto. En el Test de Rorschach, la subjetividad de las figuras presentadas sugiere, por asociación de los detalles, imágenes visualizadas anteriormente y asentadas en el imaginario. (Leonardo da Vinci afirma haberse inspirado en imágenes proyectadas en piedras húmedas). También a veces, al mirar al cielo, se busca descubrir formas absolutas en las etéreas nubes. Imágenes que son puramente fantasiosas, alucinaciones; algo similar a lo que sucede en los sueños. Una belleza libre e independiente.

61 Helmut Rinkmann, El Test de Rorschach. Introducción a su estudio y utilización. (Santiago de Chile: RIL editores, 2014), 105-106.

62 Javier Seguí, Dibujar, proyectar (I) - Escritos acerca del dibujar y el dibujo y del proyectar y el proyecto arquitectónico (Madrid: Instituto Juan Herrera de la Escuela de Arquitectura de Madrid, 2003), 21.
} 
También la ciudad se puede solucionar creando huecos, quitando, vaciando la masa densa. Existen en este momento algunos movimientos arquitectónicos ${ }^{63}$ "que tienen esa especie de sensibilidad hacia el vacío y hacia el grado cero de la arquitectura" 64 y que luchan por conquistar el lugar vacío, por sustraer materia en vez de seguir añadiéndola; restar volumen en lugar de la tradicional suma.

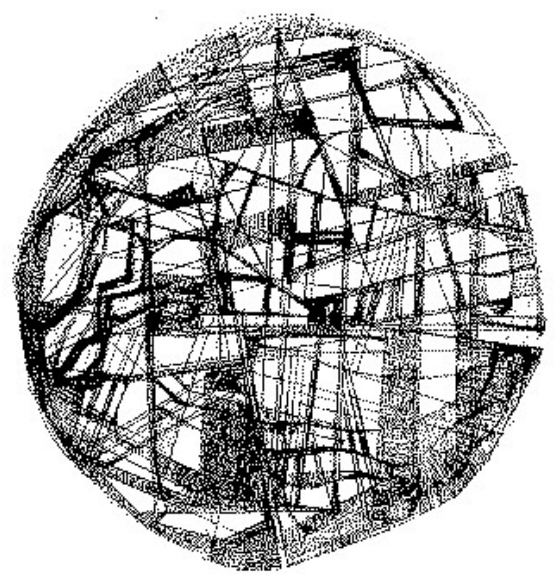

PLANTA. Javier Seguí.

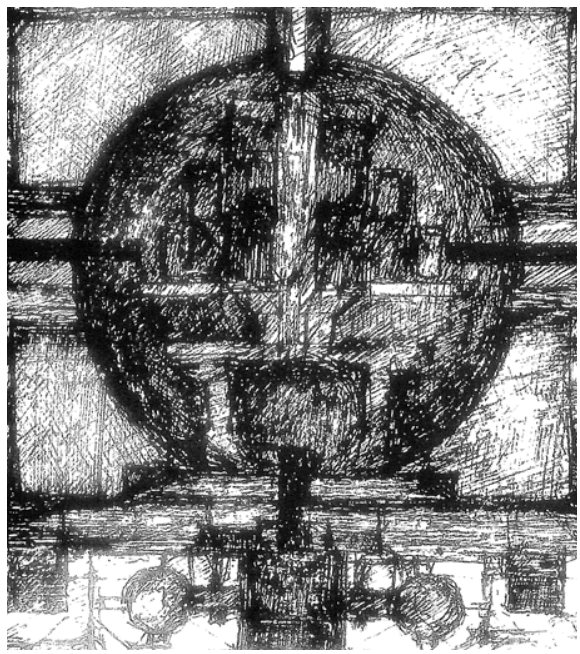

CIUDAD TEATRO. Raymond Abraham. Sección.

Vaciar es crear un marco donde puedan darse todas las experiencias. El vacío es la condición donde todo es posible, la posibilidad que dejan todas las líneas. Palazuelo asegura que todas las líneas están ya dibujadas y, en el fondo, lo que hace el arquitecto es quitar una de ellas, en lugar de ponerla. Como afirma

\footnotetext{
63 El grupo n'UNDO propone actualmente lo que décadas antes intuye Javier Seguí
} cuando propone la Ciudad Radical. Al igual que Seguí, ellos proponen una acción exactamente opuesta a todo lo que se hace en arquitectura: "n'UNDO propone una actitud, una manera de hacer re-arquitectura, interviniendo en el territorio y la ciudad desde la resta y la renuncia. No se trata del menos es más, sino del nada es más. Se plantea la no-construcción como solución ante determinadas propuestas o intervenciones futuras, innecesarias o no pertinentes; la reutilización de las estructuras abandonadas o infrautilizadas; la minimización de elementos existentes de gran impacto y el desmantelamiento de aquellas construcciones o piezas insostenibles, perniciosas, prescindibles o inútiles. Se trata de valorar la ausencia y la preexistencia, por encima de la construcción y el material: se trata de reparar, de limpiar, de recuperar el paisaje, el territorio y la ciudad; sus vacíos y sus silencios. Su trabajo se fundamenta en la crítica, el debate y la reflexión, desde donde desarrolla su base teórica, que da lugar a diversas prácticas y actuaciones basadas en la participación y la multidisciplinariedad. El enfoque n'UNDO se hace extensible a otras áreas vitales, invitando a la reflexión, el debate y la acción" en n'UNDO, "Re-arquitectura del territorio y la ciudad desde la resta y la renuncia," n'UNDO,2014, 20 de abril de 2015, http://www.nundo.org/.

64 Prada, "Componer con vacío," 62. 
Seguí: "Sólo disertamos para señalar "vacíos", ámbitos disposicionales, rastros y condicionantes de la experiencia narrable... verbalizable, hablable."65

En este vacío, área de oportunidad, todo es posible, porque no hay nada; es vacío que surge al quitar algo a lo lleno, y no el vacío inmenso, como el desierto. Un conjunto de edificios erigidos nunca podrán ser llamados ciudad; la ciudad es encuentro, es ciencia humana, o, como dice Seguí, "una escultura preparada desde siempre para albergar diversas situaciones." 66

Con esta nueva herramienta para materializar la inmaterialidad, Seguí propone una serie de experimentos:

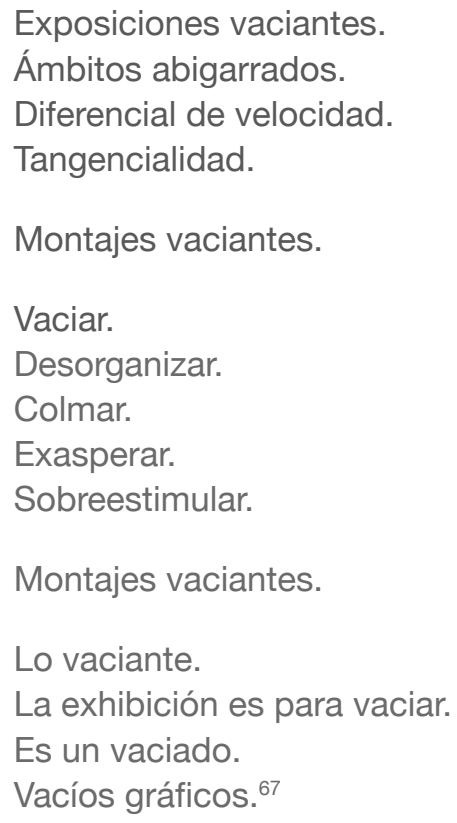

Al observar el mencionado listado, se hace evidente la búsqueda exasperada del fundamento del "vacío". Seguí parte de la premisa de que "el papel en blanco es un lugar lleno de blando que se vacía cuando se rotura, cuando se le trazan rasgos."68 Estos experimentos desean testar, provocar, "desorganizar", "colmar" e invertir la percepción tradicional de las formas, potenciando la actividad intelectual que, como dice "consiste en encontrar los lugares vacíos ad hoc, donde se pueden insertar las sentencias y nociones de la actividad." 69

\footnotetext{
65 Seguí, Dibujar, proyectar (LXVII) - Vacío, vaciar (2).

66 Javier Seguí, "Textos reunidos sobre ciudades radicales," (Madrid: Instituto Juan Herrera de la Escuela de Arquitectura de Madrid, 2008).

67 Seguí, Dibujar, proyectar (LXXI) - Vacío. Oquedad. Reverso., 9.

68 Seguí, Dibujar, proyectar (LXXI) - Vacío. Oquedad. Reverso., 18.

69 Seguí, Dibujar, proyectar (LXVIII) - Vacío, vaciar (3), 24.
} 
Para Seguí, hablar de vacío es también hablar de muerte, ese vacío desconocido que "nos espera de frente, aunque se organice desde dentro". ${ }^{70}$ La muerte es la última morada del vacío, la más radical. La proximidad de la muerte hace imaginar ese contenedor vacío de miedo e incertidumbre. Con ella se refuerza el camino hacia el vacío, la desaparición, la nada: "La muerte es la certeza de la desaparición, es el lugar radical de la ausencia, el fondo inalcanzable de la vida que se hace presente estáticamente en el miedo nocturno como lugar radical del abandono." ${ }^{71}$
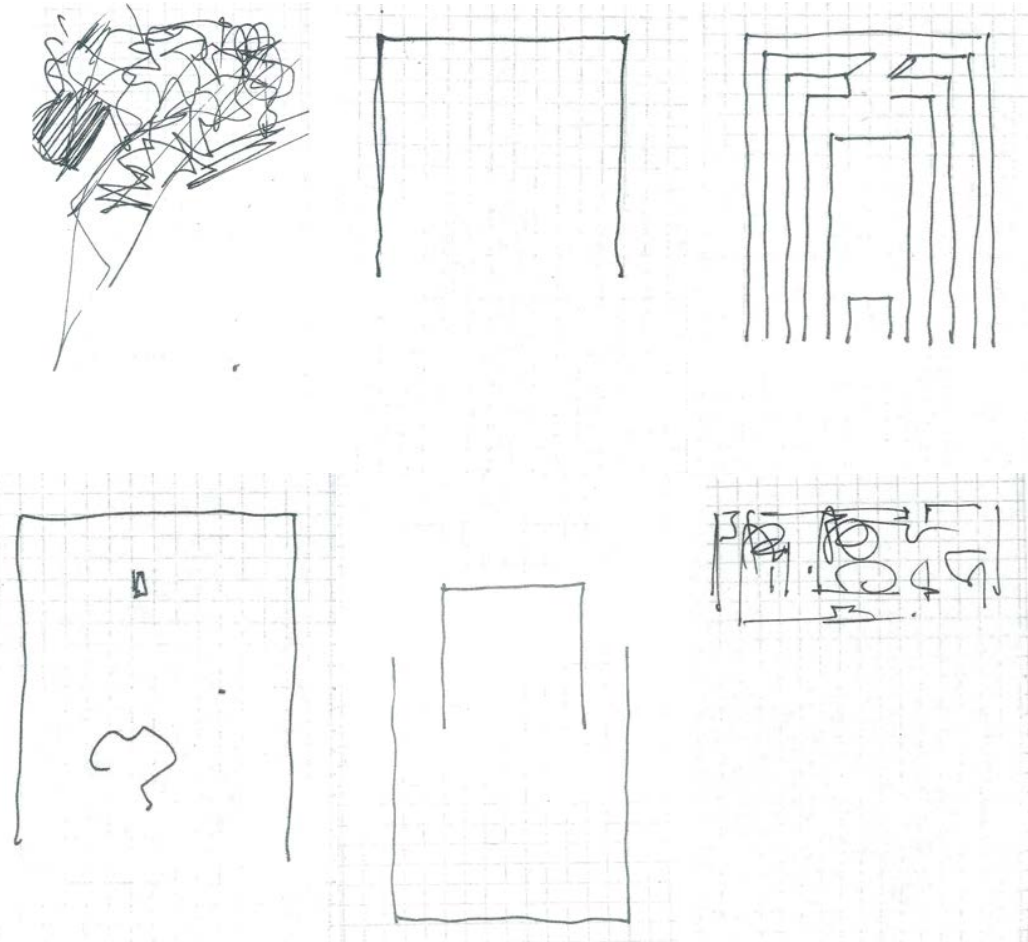

EXPOSICIONES VACIANTES, (2012). Javier Seguí. 
reflexionar

\section{2 (re)nombrar}

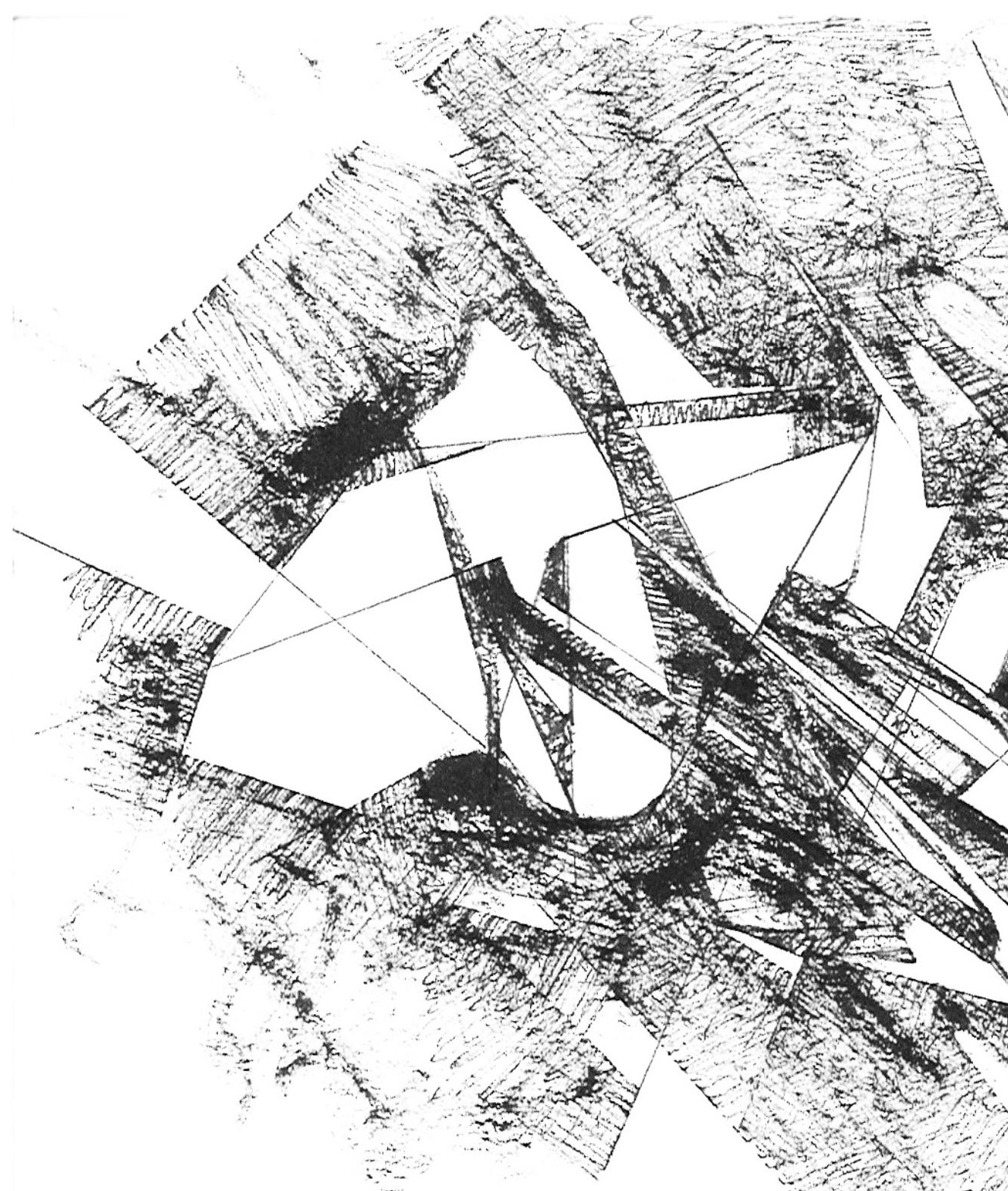


...tengo la impresión de que el lenguaje es usado cada vez más de manera aproximada, casual, negligente (...); una peste del lenguaje que se manifiesta como pérdida de fuerza cognoscitiva y de inmediatez, como automatismo que tiende a nivelar la expresión en sus formas genéricas, anónimas, abstractas, a diluir los significados, a limar las puntas expresivas, a apagar cualquier chispa que brote del encuentro de las palabras con nuevas circunstancias. ${ }^{72}$

Las palabras habitan el imaginario y condicionan el pensamiento y el discurso. Son, en parte, responsables de la manera de articular y entender la realidad. Por ese motivo, Seguí manifiesta un gran interés por los términos manejados en la escuela, de tal forma que prepara, junto con los profesores que siempre lo acompañan, una recopilación terminológica que queda patente en los Anales de la Cátedra de 1979 y que reúne en 1996 en un Glosario de Términos ${ }^{73}$, dentro de la materia Análisis de Formas Arquitectónicas. Según señala, este glosario no pretende ser un ensayo semántico sino "llegar a algunas convenciones básicas que facilitaran la comunicación entre docentes y en la propia pedagogía" ${ }^{74}$ bien como acotar determinados términos que, como explica, tiene un equivocado "uso y abuso en el marco académico." 75

Las palabras (significantes) funcionan cuando están llenas de significado (de sentido; de contenido, de apropiación). Pero se pueden vaciar... e intentar otros rellenos... o colmar el contenido hasta naturalizarlo. Entender las palabras como contenedores/recubridores/albergantes... es verlas como edículos... Parte del gran edificio de la lengua. ${ }^{76}$

\footnotetext{
72 Javier Seguí, Oscuridad y sombra. Experiencias en dibujo y arquitectura (Madrid: Instituto Juan Herrera de la Escuela de Arquitectura de Madrid, 2003).

73 Este glosario, dividido en dos partes, supone un primer intento de demarcar el léxico arquitectónico académico. En la primera parte se agrupan los términos que considera ser empleados más confusamente, como por ejemplo: concepto, equilibrio, espacio, estética, forma, formalismo, función, idea, luz, necesidad y percepción. En la segunda parte propone nuevos significados de las palabras para evitar confusiones, como por ejemplo: acción, acechar, acompañar, acto, albergar, amplitud, análisis, arcadia, arquitectura, artefacto, artificial, anticipación, argumento, boceto, casa, ciudad, civil, cognóstico, consciencia, conducta, configuración, conjetura, construcción, cuotidiano, criterio, critica, cultura, desencadenante, deseo, destreza, dibujo, edificio, entusiasmo, ergonomía, esbozo, estimulo, expresión, fantasía, ficción, figura, figuración, habilidad, habitáculo, hábito, ilusión, imagen, imaginación, inimaginable, instancia, interpretación, lengua, lenguaje, mediar, medio, método, metodología, mito, morada, noción, objetivo, ocurrencia, oficio, organización paradigma, plan, proceso, provocar, proyectar, quehacer, radicalizar, recinto, referente, representación, requerir, rutina, significado, situación, tanteo, tentativo, tema, teoría, vigilancia.

74 Javier Seguí, "Glosario de términos (15-04-96)," (Madrid: Instituto Juan Herrera de la Escuela de Arquitectura de Madrid, 1996).

75 Javier Seguí, "Glosario de términos (15-04-96)," (Madrid: Instituto Juan Herrera de la Escuela de Arquitectura de Madrid, 1996).

76 Seguí, Dibujar, proyectar (LXX) - Vacío, vaciar (5), 18.
} 
Asumir que "el ser humano piensa solamente a través del lenguaje", ${ }^{77}$ implica poder afirmar que la realidad sólo tiene sentido si se puede expresar, comunicar. Lenguaje es tradición, es vehículo antropológico y, por tanto, condición y condicionante de la manera de entender el mundo del ser humano. Como dice Seguí, "el poeta es un artesano del lenguaje que engendra y configura imágenes por el solo medio del lenguaje."78

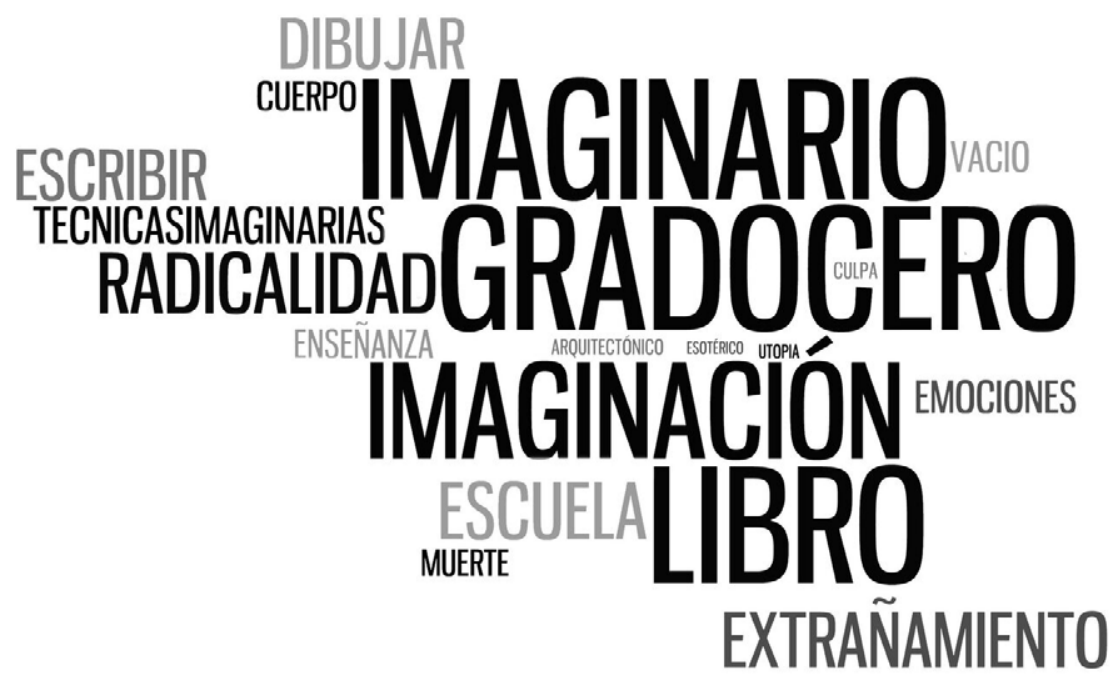

NUBE DE PALABRAS, (2015). Cartografía llevada a cabo llevado a cabo con el programa informático Wordle, utilizando las entrevistas realizadas a Javier Seguí desde el año 2013 hasta 2015.

Los esquemas lingüísticos vienen determinados por los contextos en los que se mueve el individuo, construyen su memoria y dan lugar a su manera de interpretar el futuro. Hablar de palabras es también hablar de lenguaje, el complejo sistema que permite que el ser humano se exprese y sea entendido por el otro.

Sobre éste, Seguí establece una diferencia entre lenguaje hablado -"conjunto de sonidos articulados con que el hombre manifiesta lo que piensa o siente"-, y lenguaje grafico -"conjunto de señales y reglas gráficas que dan a entender contenidos configurales" -.79

A través del pensamiento de Ivan Illich, Seguí descubre que el lenguaje se encuentra salpicado de palabras-ameba, híbridas, capaces de abarcar todo sin que necesariamente signifiquen nada.

7 Giorgio Agamben, La potencia del pensamiento (Barcelona: Anagrama, 2008), 20.

78 Javier Seguí, "La imaginación (1) (31/07/10)," (Madrid: Instituto Juan Herrera de la Escuela de Arquitectura de Madrid, 2010).

79 Seguí, "Glosario de términos (15-04-96)," 
Para Seguí, "el lenguaje lo es todo", porque la realidad no es más que distintos tipos de lenguaje.

He aquí, tal vez, el límite humano fundamental: el lenguaje no es una "herramienta-espejo" adecuada para los movimientos físicos del cuerpo humano. $Y$ sin embargo yo escribo y el lector lee un libro sobre práctica física; Diderot y sus colaboradores reunieron un conjunto de volúmenes sobre este tema que, apilados, llegaban casi al metro ochenta de altura. ${ }^{80}$

En relación al lenguaje hablado, Seguí lo divide en dos elementos distintos: la lengua, para referirse al conjunto de señales, signos y reglas que pertenecen a un sistema de expresión "propio de un pueblo o nación o común a varios" y que permitie la comunicación entre sí; y el lenguaje, que, actualmente "acometido por la lingüística y la lógica formal", se trata de "un sistema de signos convencionalizados que, sometidos a reglas gramaticales y sintácticas, expresan, apelan y representan contenidos mentales designables." ${ }^{81}$

Cuando habla de lenguaje gráfico reconoce que, de la misma manera que se pueden expresar y representar verbalmente "contenidos intencionados, más o menos precisos de significación"82, gráficamente también es posible.

Dada la complejidad de estos sistemas, para poder renombrar, es preciso activar la imaginación, porque sólo ésta permite acabar con las dualidades establecidas por la ideología y encontrar el contenido que queda olvidado entre sus extremos. Renombrar es volver a nombrar, darles a las palabras otro significado y otro significante, aprenderlas de nuevo, porque el ser humano es, de alguna manera, "un creador de una nueva realidad, de un mundo vacío que puede llenar con sus propios objetos artificiales." ${ }^{33}$ Sobre ello, Seguí cita a Susan Sontag: "Los seres humanos están de tal forma 'decaídos', que necesitan empezar por el acto lingüístico más simple: nominar las cosas." ${ }^{84}$

Se sabe que los inuit cuentan con distintas denominaciones para la nieve, en virtud de su grado de limpieza, de dureza, de transparencia o de peligrosidad. Los significados con que dotamos a las palabras son el reflejo del grado de expresión que pueden

\footnotetext{
80 Sennett, El artesano, 121.

81 Seguí, "Glosario de términos (15-04-96),"

82 Seguí, "Glosario de términos (15-04-96),"

83 F. León Florido, "Forma y dibujo. Notas para una fundamentación filosófica del proyecto," Ega 6 (2001): 23.

84 Susan Sontag, A Vontade Radical: Estilos, trad. João Roberto Martinhs Filho (São

Paulo: Companhia das Letras, 1987), 31.
} 
abarcar las sociedades. ${ }^{85}$ Quienes se dedican a la enseñanza del "arte de construir edificios" son, por consiguiente, responsables de alejarse de los conceptos del clasicismo, construir una nueva identidad que sea compatible con los cambios continuos que las sociedades experimentan cada día.

En ese sentido, considera que el profesor debe ser capaz de reinventarse, depurar sus conceptos, inventar un nuevo personaje e identificarse con el alumno, viviendo con él "la inocencia de las operaciones primarias". ${ }^{86}$

(...) no de la manera ortodoxa con la que se imparten las humanidades en la enseñanza reglada, sino de un modo más ocasional, empezando por la clarificación etimológica de términos, el encuadramiento interdisciplinar de temáticas diversas y la crítica de los tópicos usados en la vivencia delirante de la profesión. ${ }^{87}$

Javier Seguí siente la necesidad de redefinir determinadas palabras para acomodar sus nuevos imaginarios. Las palabras existen para pensar y expresar la vida, y sólo ellas, mediante su disciplina, pueden "liberarnos de la cháchara y devolvernos el silencio". 88

Junto con el hábito, conforman la vida y la convivencia. A este respecto Javier Seguí alerta:

El rechazo del hábito es otro de los espejismos de nuestra época. Por una parte, el concepto de hábito perdió su significado al entenderse como un mecanismo automático, es decir, como una repetición que nos priva de la innovación que caracteriza a la vida (por ejemplo, en W. James o en H. Bergson). Por otra parte, toda la ideología del consumo rechaza la repetición y estimula el culto por lo novedoso. ${ }^{89}$

Las palabras, instrumentos del lenguaje, son los vehículos simbólicos que permiten que el otro pueda descifrar aquello a lo que la imaginación da forma.

Del Ser al hacer, de Maturana, que es una reflexión científica en la que dice que el hacer es lo que construye los mundos. Cada uno tiene su mundo. La ciencia es un discurso coherente, comprensible para otro, que se refiere con experiencias con el exterior. Hay que abandonar las cosas del principio del

\footnotetext{
85 VV.AA, Diccionário metápolis arquitectura avanzada (Barcelona: Actar, 2001), 430.

86 Seguí, 18 de febrero, 2014.

87 Seguí, "Glosario de términos (15-04-96),"

88 Javier Seguí, Dibujar, proyectar (XIX) - Utopias, fantasias y ciudades radicales (1) (Madrid: Instituto Juan Herrera de la Escuela de Arquitectura de Madrid, 2009), 7.

89 Seguí, Dibujar, proyectar (XIX) - Utopias, fantasias y ciudades radicales (1), 7.
} 
ser, del origen del ser y meterse en el estudio, como decía Descartes, del ego. De cómo el ser uno mismo va fabricando ese mundo. Aquí descubre que el lenguaje es la "madre del cordero" de la operación. Si el otro no te entiende, nada sirve para nada. Y explicar que lo que tú haces es porque estas persiguiendo un comportamiento de algo que no eres tú. Tú inventas la realidad. Es inalcanzable, así que lo que hacemos entre todos es una especie de montaje para referirnos a la realidad en función de lo que vemos. ${ }^{90}$

Las palabras, como las metáforas, los mitos, la ideología o la utopía, determinan el imaginario. Renombrar es conceder una oportunidad a lo novedoso, a lo extraño en apariencia.

Así pues no sólo el nombrar, no sólo cada manera de nombrar, determina la realidad de lo nombrado. En ocasiones, también son las maneras de no nombrar, el silencio en la charla o el blanco en la hoja de papel, los que transfieren significado y realidad a lo silenciado. ${ }^{91}$

Renombrar palabras es renovar el imaginario. Se trata de un proceso de redefinición fundamental en la enseñanza. Para Seguí, un buen profesor debe ser capaz de hacerlo, olvidar su camino y no exigir al alumno que repita su propia experiencia y discurso; debe acompañar al alumno en su propio caminar y empezar el camino a su lado como si no lo hubiera hecho nunca.

Desde siempre supe que la arquitectura es una palabra metafísica que se refiere probablemente a la capacidad de las personas para organizar el mundo. Pero no es una propiedad externa de las cosas. La arquitectura es una propiedad interna. Eso lo dice el diccionario. Así que como capacidad no se puede enseñar. O se tiene o no se tiene. Mejor no hablar de arquitectura. Lo nuestro son los edificios. Hacemos edificios, proyectamos edificios e intentamos comprender edificios y no arquitecturas, que nadie sabe lo que es. ${ }^{92}$

Después de casi cincuenta años impartiendo clases en la Escuela Superior Técnica de Arquitectura de Madrid, Javier Seguí desvela:

Yo, ahora, en todas las cosas que he escrito, donde aparece
la palabra arquitectura, la quitaría. Y es que ahora yo no estoy
en ese lugar. Yo no pienso así ahora. Cómo pienso yo ahora...
a lo largo de todos estos cuadernos se ve un cambio. Se nota
perfectamente el salto de una cosa a otra. Y al traer al primer

90 Javier Seguí, entrevistado por Maria Brito, 29 de julio, 2015, Grabación.

91 Emmanuel Lizcano, Metáforas que nos piensan. Sobre ciencia, democracia y otras poderosas ficciones (Madrid: Ediciones Bajo Cero, 2006), 144.

92 Javier Seguí, entrevistado por Maria Brito, 5 de mayo, 2014, Grabación. 
término un concepto, una reflexión, o una cosa que al principio estaba en un segundo plano... van emergiendo cosas. ${ }^{93}$

Es preciso inventar nuevas palabras, llenarlas de otros significados, eliminando las connotaciones históricas y políticas que han ido acumulando a lo largo de décadas. Como afirma, John Cage: "Si la palabra 'música' se considera sagrada y reservada para los instrumentos de los siglos dieciocho y diecinueve, podemos sustituirla por otro término más significativo: organización de sonido."94

En El grado cero de la escritura, ${ }^{95}$ Roland Barthes señala la necesidad de hacer tabula rasa del lenguaje; no destruirlo por completo, pero sí recrearlo. Sólo así se pueden romper las ataduras, los hábitos, la rutina y los prejuicios, algo indispensable para conquistar la libertad.

Parece que las palabras están gastadas y los imaginarios, petrificados en el tiempo. Actualmente, la información llega a una velocidad de vértigo, desde todas partes. Se impone vaciar el contendor para volver a llenarlo con palabras nuevas, o con las mismas, pero redefinidas y adaptadas a los tiempos actuales.

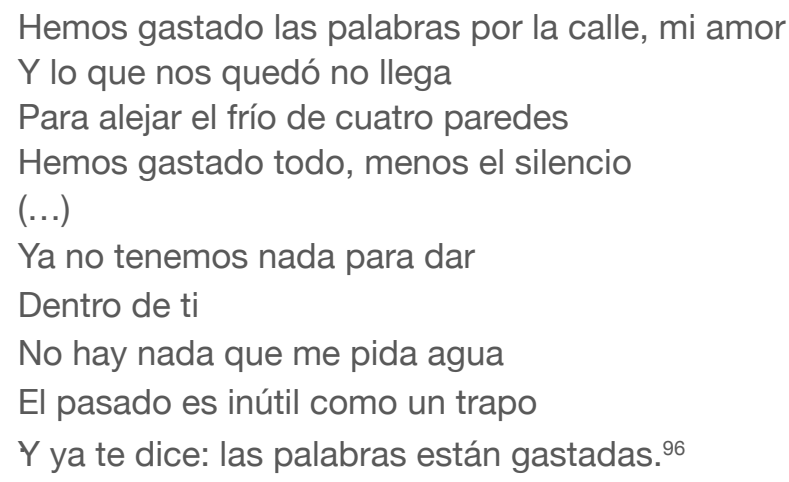

Para Seguí, "arquitectura es una palabra absurda"97 y, por lo tanto, es la que más necesita ser redefinida y reubicada. El diccionario de la Real Academia Española indica:

$\sim$ arquitectura.

(Del lat. architectura).

1.f. Arte de proyectar y construir edificios.

\footnotetext{
93 Seguí, 8 de octubre, 2013.

94 John Cage, "El futuro de la música: Credo," en Escritos al oído (Murcia: Colegio Oficial de Aparejadores y Arquitectos Técnicos, Colección de Arquitectura, 1999), 52.

95 Roland Barthes, El grado cero de la escritura. Seguido de nuevos ensayos criticos., trad. Nicolás Rosa (Madrid: Siglo XXI, 2005).

96 Eugénio de Andrade, Poemas: 1945-1965 (Porto: Editorial Inova, 1971).

97 Javier Seguí, entrevistado por Maria Brito, 25 de marzo, 2014, Grabación.
} 
2. f. Inform. Estructura lógica y física de los componentes de un computador.

$\sim$ civil.

1. f. Arte de construir edificios y monumentos públicos y particulares no religiosos.

$\sim$ hidráulica.

1. f. Arte de conducir y aprovechar las aguas, o de construir obras debajo de ellas.

$\sim$ militar.

1. f. Arte de fortificar.

$\sim$ naval.

1. f. Arte de construir embarcaciones.

$\sim$ religiosa.

1. f. Arte de construir templos, monasterios, sepulcros y otras obras de carácter religioso. ${ }^{98}$

Como se puede comprobar, la palabra arquitectura no se refiere sólo a edificios. Para Javier Seguí, la arquitectura es el fundamento que organiza, siguiendo la teoría de José Ricardo Morales, quien añade:

Estiman la arquitectura como cosa acabada, conclusa y hecha, absteniéndose de ver que la arquitectura no pertenece al mundo de "lo dado", de aquello que el hombre encuentra frente a él, existente sin su intervención factiva o efectiva. Porque la arquitectura supone, principalmente, un hacer, y, por lo tanto, su auténtica comprensión requiere establecer previamente cuáles fueron las condiciones de semejantes acciones especializadas. ${ }^{99}$

Por este motivo, todo tiene arquitectura o, como el mismo dice, "la arquitectura está en todas partes". Se habla de arquitectura en el ámbito de la informática, del Estado y, como menciona Seguí, Esherick habla incluso de arquitectura del cerebro -diseño-, de la sociedad -uso-, de la técnica -construcción- y del territorio -medio ambiente-. ${ }^{100}$ Por esta razón, y porque, en su opinión, los arquitectos han intentado apropiarse de la palabra, ésta es su reflexión a este respecto:

Para mí hay una batalla muy fuerte, que viene además de la carrera. (Víctor d'Ors fue el primero en diferenciar bien edificación de arquitectura). (...) Llamar a los edificios arquitectura

\footnotetext{
98 Real Academia Española, "Arquitectura," 15 de mayo de 2015, http://lema.rae.es/ drae/srv/search?id=rmOfeN89wDXX2VODpXNR.

99 José Ricardo Morales, Arquitectónica. Sobre la idea y el sentido de la arquitectura (Chile: Universidad del Biobio. Facultad de arquitectura y construcción., 1984), 114.

100 Javier Segui, “J. Muntañola. “¿Se puede enseñar la arquitectura?” (13-03-03)," 2003,

http://www.javierseguidelariva.com/Res/R\%20105.html.
} 
es falso, porque la arquitectura es el arte de hacer el orden y efectivamente es consustancial con un edificio. No se habla de arquitectura de un cuadro o de una obra de arte, pero la tiene también. ¿De qué estamos entonces hablando en esta Escuela? En esta Escuela estamos hablando de edificación, y lo que hacemos es diseñar edificios. No proyectarlos, diseñarlos. ${ }^{101}$

Si se consulta el diccionario de Ferrater Mora, se aprecia que no figura la palabra arquitectura, pero sí arquitectónica. En la era digital, es preciso reinventar los conceptos y acomodarlos a un nuevo imaginario en constante mutación. Seguí afirma que "asumir la palabra arquitectura como campo de actividad es aceptar el delirio de que la producción de edificios se puede resumir, reducir, esenciar, en el trabajo del que diseña el edificio y se responsabiliza de su apariencia."102 Desbloquear la palabra arquitectura equivale a lograr que sea permeable a todas las relaciones y acciones exteriores; permitir que un nuevo concepto inunde un contenedor cerrado sobre su propio significante. 

reflexionar

\section{3 llegar al grado cero}

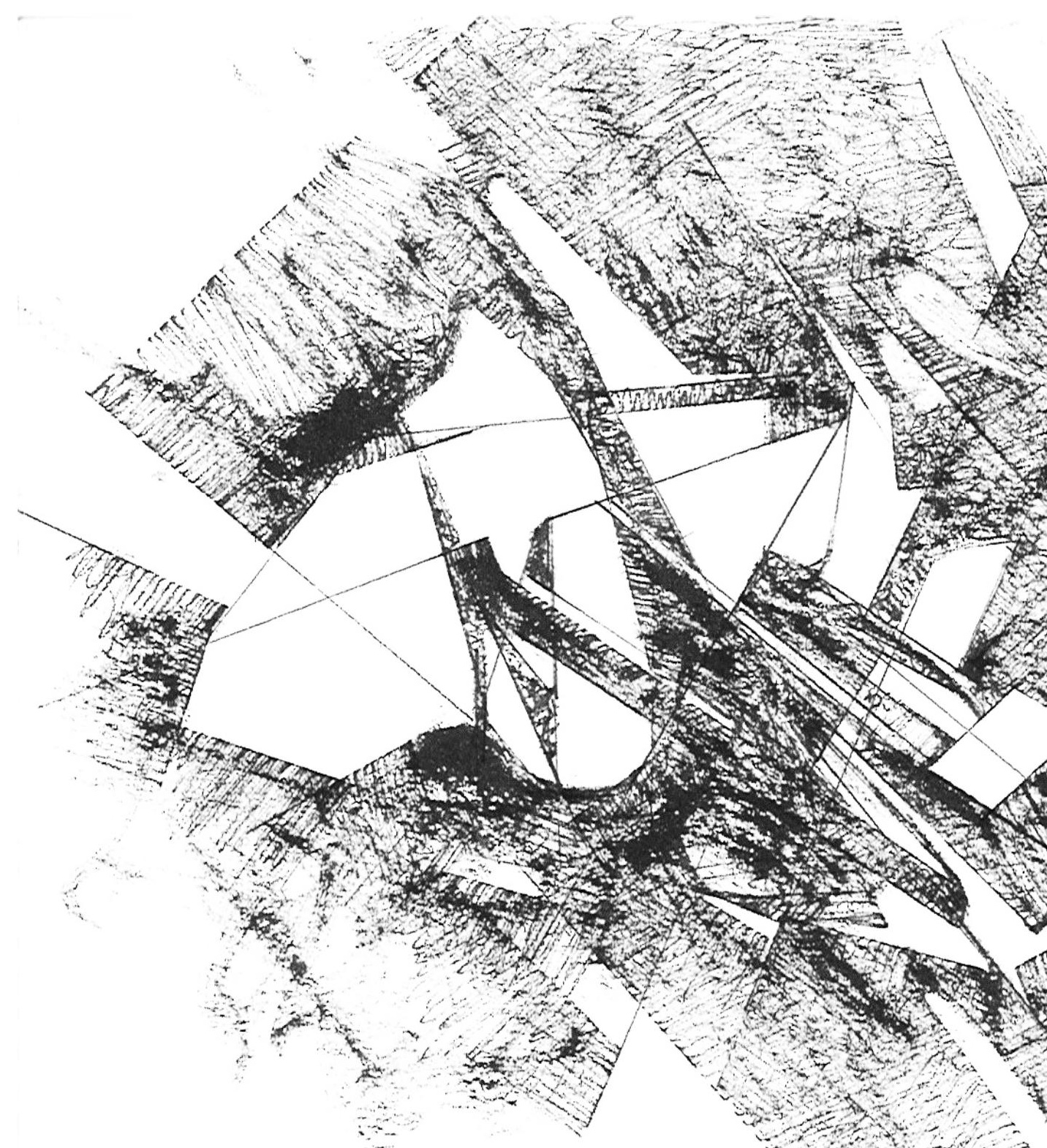


El grado cero viene un poco como consecuencia de una especie de cansancio. ${ }^{103}$

Con estas palabras se refiere en 2013 Javier Seguí, arquitecto, al grado cero. Tiene setenta y tres años y es profesor emérito.

No aparenta estar cansado. Habla sin parar en los momentos en que no dibuja. Escribir, dibujar y hablar.

Es en la última etapa de su vida académica y profesional, en 2001, cuando, en su proceso de búsqueda de los fundamentos, descubre el grado cero del escritor francés Roland Barthes. Desde ese momento dedica parte del tiempo que consagra a la arquitectura a explicar los mecanismos que conducen al grado cero arquitectónico, aplicándolo a todos los ámbitos implicados. A partir del extrañamiento, respecto a su propia cotidianidad, Javier Seguí descubre e intenta, a través de palabras y dibujos, vaciar críticamente su propio imaginario para recomenzar sin objetivos, una acción ininterrumpida y, presumiblemente, inacabada.

Todas las disciplinas necesitan una actualización permanente para acompañar unas épocas cambiantes. Han de "interrogarse de nuevo, redefinirse, precisar su situación en el interior de la sociedad, sus relaciones (...) con las ciencias humanas y con el poder político". ${ }^{104}$ Javier Seguí considera necesario ir a contracorriente, cuestionándolo todo y no aceptando ninguna proposición como verdadera por el mero hecho de ser aceptada por la mayoría; negar todo lo existente como estrategia de exploración de lo que queda por descubrir.

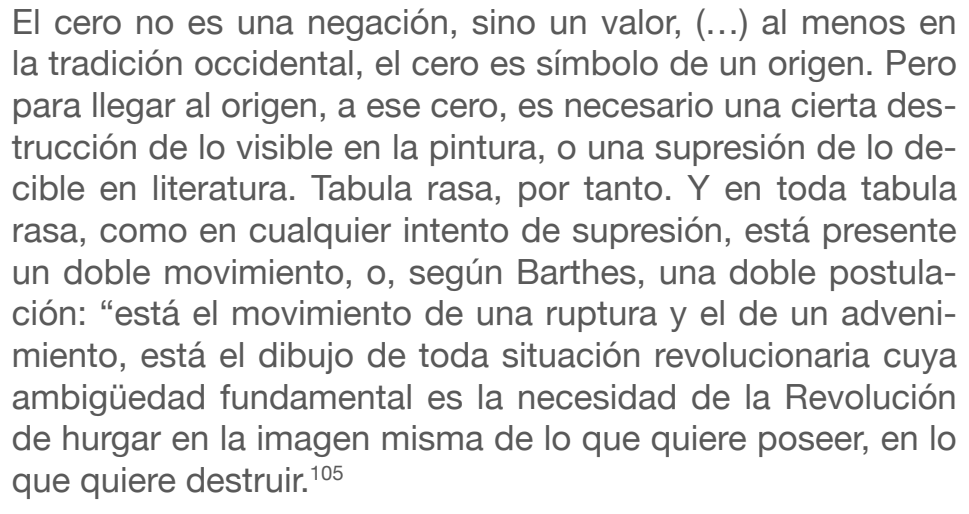

Señala la necesidad de cuestionar repetidamente el sistema,

\footnotetext{
103 Seguí, 8 de octubre, 2013

104 Hilia Moreira, "La semiología literaria en Francia: Conversaciones con Barthes, Genette, Bremond y Soriano," Texto crítico 1, Centro de Investigaciones Lingüístico-Literarias (1978): 15.

105 Miguel Hernández-Navarro, "El cero de las formas. El cuadro negro y la reducción de lo visible," Inmafronte $n^{\circ}$. 19-20 (2007/2008): 135.
} 
pero en lugar de poner de manifiesto su lado negativo, "darle la vuelta y ponerla como a favor". ${ }^{106}$ ¿Es posible ir siempre contra el sistema? Barthes advierte que para subvertir el poder no hay que ir en su contra, pues, haciéndolo, existe una fuerte posibilidad de quedar atrapado en otro. El truco es alejarse, no estar "contra el poder, sino fuera del poder". ${ }^{107}$

Toda escritura revolucionaria termina integrándose en el sistema, haciéndose prisionera de la literatura que intenta negar. La escritura vive en la eterna tragedia de formar parte de una Historia de la que no es responsable, pero que es la única que puede utilizar. El escritor puede crear un lenguaje libre, pero siempre la devuelve fabricada. ${ }^{108}$

Lo que pretende el grado cero no es acabar con todo lo anterior, puesto que cuando creamos algo nunca es un acto estrictamente espontáneo sino que se tienen como referencias otras obras que han sido hechas. Cuando se crea algo, se "está siempre en un estado de influencia, o de imitación, o de mediación, o de reacción, con respecto a los (...) lo han precedido y que lo rodean." 109

El grado cero pide una segunda vuelta donde la experiencia acumulada de la primera componga sólo las huellas que no hay que volver a pisar.

De pronto, adquieres una clarividencia insospechada y todo lo nuevo que te sucede no incide en el yo antiguo y habitual, sino que, junto con los nuevos hechos sorprendentes, hay un yo íntimo totalmente nuevo y perfectamente integrado en el mundo, que consiste sólo en receptividad y presente -un presente que nada debe al pasado y que irrumpe bruscamente en el ser por generación espontánea. ${ }^{110}$

Javier Seguí considera definitivo este aspecto en el cambio de su recorrido pedagógico y en su forma de percibir el mundo. Como comenta Juan Daniel Fullaondo, hombres con la talla intelectual de Javier Seguí suelen transitar varios recorridos, "como si constantemente estuvieran dispuestos a volver a empezar a rehacer su propio rostro."111

\footnotetext{
Seguí, 8 de octubre, 2013

107 Moreira, "La semiología literaria en Francia: Conversaciones con Barthes, Genette, Bremond y Soriano," 19.

108 Barthes, El grado cero de la escritura. Seguido de nuevos ensayos criticos., 88.

109 Moreira, "La semiología literaria en Francia: Conversaciones con Barthes, Genette, Bremond y Soriano," 18.

110 Peter Sloterdijk, El árbol mágico. El nacimiento del psicoanálisis en el año 1785. Ensayo épico sobre la filosofía de la psicología, trad. Ana $\mathrm{M}^{a}$ de la Fuente (Barcelona: Editorial Seix Barral, 1986), 40-41.

111 Fullaondo, "Javier Segui (1964-1983)," 4.
} 
¿Se necesita de nuevo un grado cero para que el arte pueda liberarse del moderno aburguesamiento mercantil y retome su verdadera función, la de provocar extrañamiento y cuestionar el imaginario construido bajo mitos y metáforas disimuladas?

Seguí sabe que, llegando a una edad, ya no se puede ser el protagonista de las acciones; porque ya no hay acciones, sino la consecuencia de todo lo sembrado. Por ese motivo propone el grado cero; no como una fuga al pasado, sino como un comienzo de un nuevo recorrido.

Cuando se llega a cierta edad, uno deja de ser el protagonista de sus acciones: todo se ha transformado en puras consecuencias de acciones anteriores. Lo que uno ha sembrado fue creciendo subrepticiamente y de pronto estalla en una especie de selva que lo rodea por todas partes, y los días se van nada más que en abrirse paso a golpes de machete, y nada más que para no ser asfixiado por la selva; pronto se descubre que la idea de practicar una salida es totalmente ilusoria, porque la selva se extiende con mayor rapidez que nuestro trabajo de desbrozamiento y sobre todo porque la misma idea de "salida" es incorrecta: no podemos salir porque al mismo tiempo no queremos salir, y no queremos salir porque sabemos que no hay hacia dónde salir, porque la selva es uno mismo, y una salida implicaría alguna clase de muerte o simplemente la muerte. $Y$ si bien hubo un tiempo en que se podía morir cierta clase de muerte de apariencia inofensiva, hoy sabemos que aquellas muertes eran las semillas que sembramos de esta selva que hoy somos. ${ }^{112}$

Los primeros escritos de Javier Seguí sobre este tema se remontan a 2001, coincidiendo con la lectura de El grado cero de la escritura, de Roland Barthes. Se da cuenta de que el escritor francés habla de lo que él lleva tiempo haciendo, pero que denomina "búsqueda del fundamento".

(...) el grado cero aparece como reflexión en Barthes con relación a la escritura. Pero a lo mejor cuando él escribe ese libro ya han pasado muchas cosas de grado cero. Desde Lautréamont, toda la escritura que empieza a ser surrealista: los OuLiPo, Perec, el propio James Joyce. (...) Barthes se da cuenta de que eso es grado cero en el momento que empieza a aparecer en Francia la conciencia de lo que se llama la Nouveau roman, donde está Blanchot, Marguerite Duras. (...) La destrucción total del lenguaje la fabrica Mallarmé (...), que empieza a escribir, otra vez, sobre las ruinas. Llegar a arruinar una cosa, deshacerla de todo, y a partir de ahí empezar a hacer. Ese es un poco el grado cero de Barthes, desde mi punto de vista. ${ }^{113}$

\footnotetext{
112 Mario Levrero, El discurso vacío (Buenos Aires: Interzona, 2006).

113 Javier Seguí, entrevistado por Maria Brito, 8 de abril, 2014, Grabación.
} 
Al analizar su discurso desde una perspectiva cronológica, resulta fácil descubrir que la lectura del libro de Barthes representa el despertar de una serie de reflexiones adicionales en torno al grado cero. "Yo creo que llevo toda la vida conectando transversalmente cosas, conceptos." 114

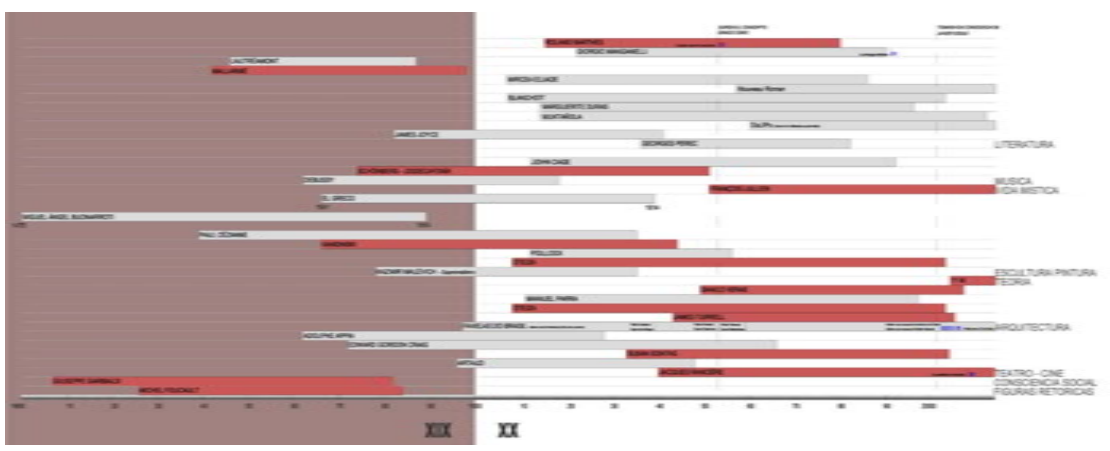

CRONOGRAMA ALREDEDOR DEL GRADO CERO DE JAVIER SEGUÍ, (2014). Las fechas asignadas corresponden al año de nacimiento y defunción. Las referencias principales derivan de la Conversación mantenida el día 14 de abril de 2014 con Javier Seguí. En color rosa se destacan las figuras más mencionadas, que Javier Seguí considera definitivas para la definición del grado cero. ANEXO 2.

Barthes evalúa de manera crítica la escritura de principios del siglo XX en Francia, oponiéndose a toda práctica asociada al academicismo literario. Su postura radical levanta revuelo por defender una forma de escribir despojada de las trampas del pretérito indefinido o del narrador omnisciente, que permiten intuir la historia y la ideología que, como dice, "dan al consumidor la seguridad de una fabulación creíble y, sin embargo, manifestada incesantemente como falsa." 115

Barthes alerta sobre los pequeños matices que contaminan la escritura y la convierten en esclava de la retórica, del orden y del ornamento; porque la escritura debe ser la función que da vida, y por eso ha de ser libre de la historia, del lenguaje y de cualquier ritual estilístico.

Pretende enterrar el pasado en pro de una "escritura blanca", neutra, sin juicios dramáticos, libre de toda sujeción; una escritura inquieta que persigue, sobre todo, su ausencia total. ${ }^{116}$

El lenguaje sometido a reglas ideológicas es, según Barthes, un lugar en la historia. A ella se aferran el estilo como ocurrencia biológica y las palabras como meros signos que luchan contra 
el desgaste del tiempo y contra el "don perverso de la banalización". ${ }^{117}$ Como añade, aunque "las palabras son piedras", "estamos condenados a pensar con palabras, a sentir con palabras, si queremos, por lo menos que los demás sientan con nosotros."118

La cuestión histórica de la escritura planteada por Barthes ya la expone como cuestión ética Jean-Paul Sartre en su libro ¿Qué es la literatura? ${ }^{119}$ Su pregunta emerge en el seno de la crisis social y política que lleva a Europa a la Segunda Guerra Mundial. En esta época, Sartre cuestiona "qué es escribir, por qué escribir y para quién escribir", reflejando la incertidumbre que conflictos de esta dimensión provocan en escritores para quienes la literatura es compromiso, síntesis y deconstrucción de una sociedad en constante evolución.

La revolución que estalla en Francia con la lucha de la pequeña burguesía y el proletariado contra la monarquía absolutista tiene un impacto decisivo en la escritura política vigente hasta el momento. A raíz de esta crisis, escritores como los franceses Théophile Gautier, André Gide, Paul Valéry, y sobre todo, Gustave Flaubert transforman "la escritura dada por la Historia en un arte, es decir, en una convención clara, en un pacto sincero que permita al hombre ocupar una situación familiar en una naturaleza todavía confusa."120

Estos autores rescatan al escritor y a la escritura de la tiranía ideológica en que están atrapados y fundan una nueva escritura artesanal, con un ritmo puramente literario. Con el abandono del clasicismo, es posible desmantelar la opacidad de la literatura anterior y hallar una forma de escritura nueva, sin ornamento; un acto puro de pensamiento que da lugar al "signo decorativo sin espesor y sin responsabilidad"121 y contraria el espíritu burgués de la novela de función ambigua:

Dar al imaginario la caución formal de lo real, pero dejarle a ese signo la ambigüedad de un objeto doble, a la vez verosímil y falso, es una constante operación en todo el arte occidental para quien lo falso se iguala con lo verdadero, no por agnosticismo o por duplicidad poética, sino porque lo verdadero supone un germen de lo universal, o si se prefiere, una esencia capaz de fecundar, por simple reproducción, órdenes diferentes por alejamiento o ficción. ${ }^{122}$

\footnotetext{
117 Vergilio Ferreira, Aparição (Lisboa: Portugalia Editora, 1965), 42.

118 Ferreira, Aparição, 42

119 Jean-Paul Sartre, ¿Qué es la literatura?, trad. Aurora Bernárdez (Buenos Aires:

Editorial Losada, 1967).

120 Barthes, El grado cero de la escritura. Seguido de nuevos ensayos criticos., 68.

121 Barthes, El grado cero de la escritura. Seguido de nuevos ensayos criticos., 13.

122 Barthes, El grado cero de la escritura. Seguido de nuevos ensayos criticos., 39.
} 
En el germinar de esta nueva forma literaria, tanto Javier Seguí como Barthes, coinciden al citar a Stéphane Mallarmé como escritor paradigmático de esta escritura democrática. Al igual que Lautréamont, busca una escritura amodal, vacía de forma y de tradición; una escritura con un "signo literario finalmente separado de su contenido que pone sin ambigüedad a la Literatura como una categoría sin relación con otros lenguajes y por ello instituye una inteligibilidad ideal de las cosas." ${ }^{23}$ Para estos escritores, la nueva propuesta literaria busca jugar con el ruido de las palabras, con su significado. ${ }^{124}$

En la cumbre de estos cambios radicales, Javier Seguí sugiere como modelo de esa liberación el libro Le Livre, de Mallarmé, del que dice que "lo leyeras como lo leyeras, siempre le sacabas un significado que tenía que ver con cualquier cosa. Se separa de las cosas concretas. Y eso es un ejercicio absolutamente de locos. Entonces no le sale." 125

Mallarmé, escritor francés del siglo XIX, aboga por la renovación de la poesía, la sonoridad y la cadencia de las palabras. En su libro piloto, Le Livre, que no llega a terminar, el escritor sugiere una nueva forma de abordar la escritura más allá del recipiente neutro del libro. Como afirma Javier Seguí, se trata de un libro "inagotable". Su texto explora un grafismo libre y distinto, que invita al lector a efectuar múltiples lecturas no lineales.

En este juego, donde el blanco de la página cobra un nuevo significado, la flexibilidad de la estructura y la interacción con el lector son las pistas esbozadas que Mallarmé proporciona para entender la poesía de manera distinta, y el propio concepto de libro.

(...) una máquina poética que hiciera proliferar poemas innumerables; o un generador de textos impulsado por un movimiento propio, en el cual las palabras y frases pudieran emerger, aglutinarse, combinarse en arreglos preciosos, para después deshacerse, atomizarse en búsqueda de nuevas combinaciones. ${ }^{126}$

Según Barthes:

Mallarmé se centró sobre la aniquilación del lenguaje, cuyo cadáver, en alguna medida, es la Literatura. (...) La escritura atravesó así todos los estados de una progresiva solidifica-

\footnotetext{
123 Barthes, El grado cero de la escritura. Seguido de nuevos ensayos criticos., 72.

124 Seguí, 28 de octubre, 2014.

125 Javier Seguí, entrevistado por Maria Brito, 20 de mayo, 2014, Grabación.

126 Arlindo Machado, "O Sonho De Mallarmé," en Maquina e imaginario (São Paulo:

Edusp - Editora da Universidade de São Paulo, 2001), 165.
} 
ción: primero objeto de una mirada, luego de un hacer y finalmente de una destrucción, alcanza hoy su último avatar, la ausencia: en las escrituras neutras, llamadas aquí el grado cero de la escritura, (...) como si la Literatura (...) sólo encontrara pureza en la ausencia de todo signo, proponiendo al fin el cumplimento de ese sueño órfico: un escritor sin literatura. $^{127}$

También en su icónico libro Para una tumba de Anatole se puede encontrar una forma libre y peculiar de "dibujar" el texto. La obra está compuesta por fragmentos y notas de un poema que lamenta la dramática muerte de su hijo de ocho años en 1879. Este libro, recopilación de notas de abandono y pérdida, no llega a ser concluido. Javier Seguí habla de él en estos términos:

Se muere el hijo, de una enfermedad, que no es una tragedia, lo que pasa es que se muere joven, y el hombre trata de hacerle un epitafio, en la tumba o en cualquier sitio. Entonces lo intenta mil veces. Cada vez que se enfrenta con la muerte de su hijo se enfrenta con todo, consigo mismo. Entonces le salen cosas sueltas, torcidas, trágicas. Resulta que el libro es la recopilación de todos esos ensayos, tentativas de escribir algo. No es una obra terminada. Es alucinante. Es de las cosas más acojonantes que he leído. Eso sí es un grado cero, porque es la búsqueda del hilo imaginal que le puede permitir escribir. Es una búsqueda constante. Arranca, lo deja. Vuelve a arrancar, lo deja. En esta época andaba Apollinaire con sus caligramas, pero no es lo mismo. La potencia que tienen estos apuntes de Mallarmé es que están escritos a mano, a veces están tachados. Resulta que el propio grafismo de lo escrito a medias es terrorífico. Es tremendo. Es fantástico. ${ }^{128}$

De esta forma singular Mallarmé deja en el siglo XIX un importante legado a todos los artistas venideros, que encuentran en su obra una huella siempre actual del experimento radical del arte; obras por terminar, ensayos de arrancar, libros sin la pretensión de encontrar nada, obras sin un final concreto donde lo importante es el proceso y no el desenlace final.

Este fundamento desestructurante -al estilo "cadavre exquis"129_

\footnotetext{
127 Barthes, El grado cero de la escritura. Seguido de nuevos ensayos criticos., 15.

128 Seguí, 20 de mayo, 2014

129 Se trata de un juego colectivo surrealista inventado en Francia en el año 1925. El cadáver exquisito es un método según el cual, cada colaborador participa en un invento artístico ensamblando palabras o imágenes y siguiendo el final de lo que escribe o diseña el contribuyente anterior. Movimiento asociado a André Breton, su fundador, es un juego destinado a la literatura, pero también a la pintura, cuyo resultado final es una sorprendente creación lúdica, intuitiva, espontánea y grupal. Dicho resultado se aprecia cuando se desvela todo el contenido. Este movimiento también contó con una adaptación a la arquitectura.
} 
pone en evidencia, una vez más, que la liberación de la literatura no supone sólo romper los cánones lingüísticos, sino también una demolición radical y extrema de la estructura que la retiene.

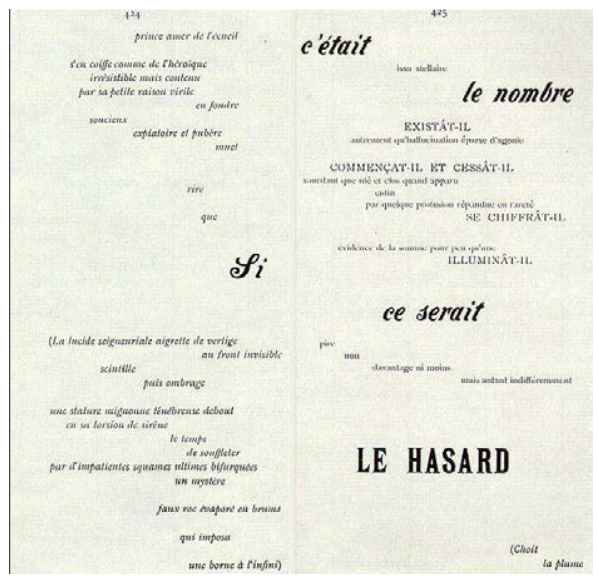

UN COUP DE DÉS JAMAIS N'ABOLIRA LE HASARD, (1897). Mallarmé. Intento de materializar los ideales de Le Livre, donde demuestra que la poesía es un juego de gramática, de sintaxis y de estructura gráfica.
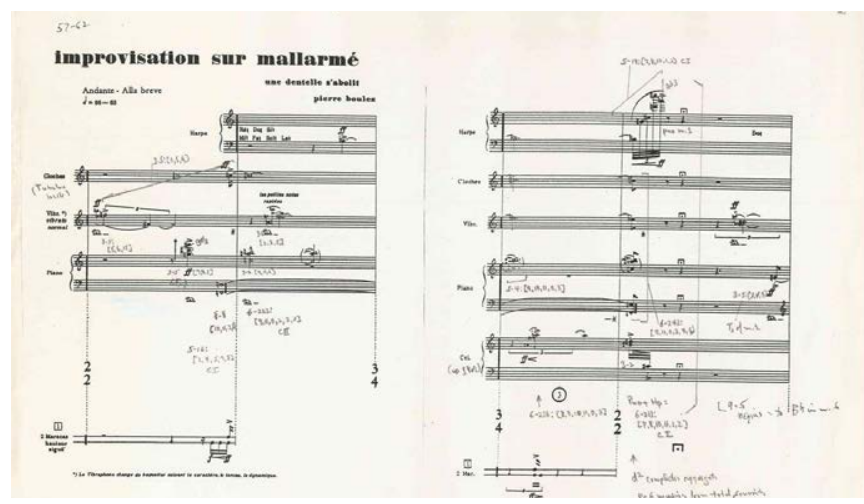

IMPROVISATION SUR MALLARMÉ, (1957). Pierre Boulez. El músico surrealista tradujo en música el Coup de Dés, de Mallarmé. Para ambos artistas las palabras se podían sustituir con idéntica importancia por espacios en blanco, conjunciones y signos de puntuación.

Su pensamiento resuena más adelante en nombres como Marguerite Duras, Charles Baudelaire o Julio Cortázar, así como en multitud de corrientes, como la patafísica ${ }^{130}$; los OuLiPo, de Georges Perec o la nouveau roman, de Blanchot.

130 Su fundador, Alfred Jarry, dramaturgo francés, entiende la patafísica como una cultura contracorriente consagrada a lo insólito y a nuevas formas de pensar. Esta ciencia crea su propia cronología y conceptos. Se dedica a buscar lo absurdo en lo cotidiano. Para su artífice, la patafísica era el «movimiento filosófico más disparatado del siglo XX: dícese de la ciencia de los estudios imaginarios». Esta ciencia practica el culto a lo insólito, porque según ellos: «buscar lo insólito y lo extraordinario obliga a distinguir lo que se ha vuelto estándar y "normal", por costumbre o por mandato. Estudiar lo inútil permite comprender lo que una sociedad considera valioso e indispensable». 
James Joyce, influyente escritor irlandés del siglo XX, protagoniza años más tarde una ruptura con los cánones tradicionales para dar lugar a una nueva estructura caótica y desordenada. Joyce declara abiertamente una guerra a la Iglesia católica porque, para él, la única manera de acceder a lo novedoso es aboliendo los límites éticos y morales que cierran y acotan el imaginario.

Para este autor, escribir es liberar "pulsiones y traumas interiores arrojándolos en un texto sin escrúpulos ni de orden moral ni de orden estético". ${ }^{131}$ En el Ulysses, su obra más famosa, el escritor rompe de manera definitiva con las convenciones e ideologías. Al contrario que muchos escritores de su época, a Joyce no le preocupa la repercusión que puedan tener sus obras en el público burgués. Además, para él es fundamental acabar con la prepotencia de las clases más ricas.

En estas referencias, dentro de su línea transgresora, no podemos dejar de mencionar a su amigo y admirador Samuel Beckett, el escritor irlandés afincado en Francia que tanta polémica creara con sus personajes deshumanizados. También Beckett presenta en su obra a personajes amorfos, neutros, donde el sujeto queda totalmente anulado; lleva a escena un abanico de personajes rudos, extrañamente inquietantes.

(...) aparecen como seres disminuidos e inhibidos, encerra-
dos en su mundo interior, que es precisamente donde se está
incubando su aniquilamiento. Entre todos ellos no existe un
protagonista que descuelle sobre los demás, todos son pa-
recidos en su miseria y, de algún modo, representan frases
cada vez más agudas de esa progresiva anulación del sujeto.
(...) Impotentes para comunicarse por el lenguaje, estos seres
mutilados y amorfos viven como moluscos agazapados den-
tro de sí mismos. ${ }^{132}$

Para Beckett, la literatura es ese espacio de lo imaginario que inventa el mundo y lo libera del pesado lastre de la historia. La desobediencia de la que hacen gala estos autores en la escritura literaria se puede identificar de la misma manera en la escritura musical. Javier Seguí menciona a Claude Debussy, Arnold Franz y Walter Schönberg como precursores de la descomposición musical.

El compositor francés Debussy abandona el vigente Romanticismo alemán en búsqueda de una nueva espontaneidad musical,

131 Juventino Caminero, "Conclusiones," en El Ulises de James Joyce: Una interpretación desde la perspectiva hebráica (Bilbao: Universidad de Deusto, 1994), 28.

132 Antonio Blanch Xiro, El hombre imaginario: Una antropología literaria (Madrid: PPC, 2005), 133. 
y para ello toma la pintura impresionista y la poesía simbolista como inspiración. Su misión consiste en liberar a la música de las reglas sintácticas y de los procedimientos de desarrollo establecidos. Schönberg, más osado, presenta un sistema compositivo totalmente innovador en relación al tradicional centro tonal, donde prepondera el empleo de determinadas notas musicales. A semejanza de lo que hace Beckett con sus personajes, el compositor austriaco propone un nuevo y revolucionario sistema compositivo dodecafónico, donde la nota preferencial queda totalmente anulada. ${ }^{133}$ En un gesto casi metafórico, las partituras de Schönberg o los personajes de Beckett constituyen una alegoría "democrática", ya que conceden a todas las notas y personajes la misma importancia.

Según Schönberg, su dodecafonía no tiene por objeto romper con el pasado, sino seguir la evolución natural que iniciara Johann Sebastian Bach. Con ella da comienzo el camino al Expresionismo, que evita la proporción clásica. Al igual que Barthes, también Schönberg se opone a la "superficialidad saturada y moral doble" de la burguesía y de su acomodación a lo conocido. ${ }^{134}$ Como los poetas en la escritura, Schönberg utiliza la partitura para denunciar la injusticia social: "Una vez que el arte es el grito de auxilio de los que sufren en la piel el destino de la humanidad... interiormente, en ellos se concentra el movimiento del mundo; para el exterior se refleja apenas el eco: la obra de arte." 135

Sin embargo, el nombre que viene a la cabeza cuando Seguí habla en grado cero de la música es el compositor anarquista de principios del siglo XX John Milton Cage. Cage compone una de las obras más polémicas y vanguardistas del siglo XX, titulada 4'33", la "pieza insonora". Se trata de una obra que no recoge significados y se aleja de interpretaciones superfluas y aparatosas; donde el silencio se presenta como una armonía solo al alcance del sabio. Sobre ella dice: "Si quieren saber la verdad de la cuestión, la música que prefiero, aun a la mía propia y a todo, es lo que oímos cuando estamos en silencio."136

\footnotetext{
133 Ulrich Michels, Atlas de musica II, trad. Flávio Pinho António Manuel Cardo, Jorge Simões y Sara Mendes, Guilherme Valente ed. (Lisboa: Gradiva, 2007), 525.

134 Michels, Atlas de musica II, 525.

135 Michels, Atlas de musica II, 525.

136 Richar Kostelantez, Conversing with Cage (New York: Limelight, 1988), 23.
} 


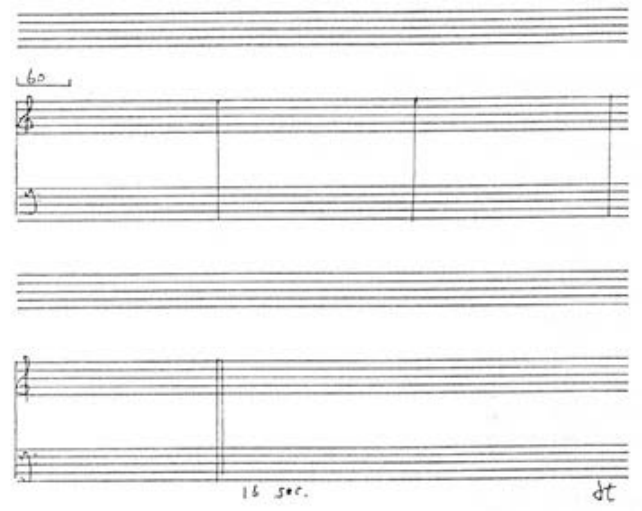

PARTITURA, (1989). Ejemplo de notación de David Tudor de la partitura original de 4'33", 1952.

A partir de este concepto, Cage propone una música natural liberada del instrumento. Una música donde el silencio es el protagonista y el responsable de simular la realidad:

Por lo tanto es muy útil si uno ha decidido que los sonidos son para entrar en sí mismos, en lugar de ser explotados para expresados sentimientos o ideas de orden. ${ }^{137}$

Lo sin forma o lo sin sonido tiene capacidad para comunicar con cualquier cosa y llegar a todas partes. Lo sin forma (sin forma sin armar, sin configurar) es la pura imaginación dinámica. ${ }^{138}$

Esta partitura, llena de sensibilidad y abstracción extrema, exprime el vaciado básico que años antes llevara a cabo el pintor ruso Kazimir Malévich en su Cuadrado blanco sobre blanco.

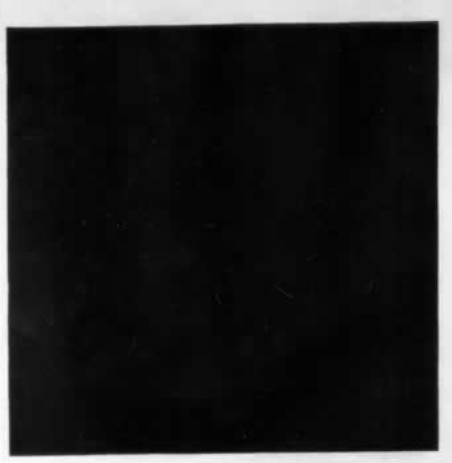

CUADRADO NEGRO, (1913). Malévich. Exhibido en 0.10 , la última exposición futurista, en Petrogrado, que se inaugura el 19 de diciembre de 1915.

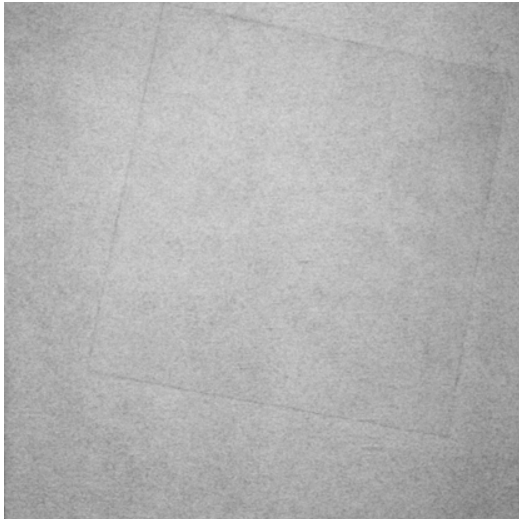

CUADRADO BLANCO SOBRE BLANCO, (1918). Malévich. El ligero cambio de tonalidad hace que la forma abstracta se pueda distinguir de la tela.

137 John Cage, "History of Experimental Music in the United States," en Silence Lectures and Writings (USA: Wesleyan University Press, 1973), 69.

138 Javier Seguí, Dibujar, Proyectar (IX) - El grado cero de la arquitectura (Madrid: Instituto Juan Herrera de la Escuela de Arquitectura de Madrid, 2006), 41. 
Malévich inicia su trayectoria artística con claras influencias del Fovismo y el Expresionismo, más adelante aprende técnicas impresionistas y postimpresionistas y se deja influir por el Simbolismo y el Modernismo. Pero son artistas como Vasili Kandinsky, Davíd Davídovich Burliúk y Mijaíl Larionov los que llevan al pintor al cubofuturismo y al abandono definitivo de los elementos figurativos. La reducción de la naturaleza a formas geométricas elementales es el camino decisivo para que el pintor dé el gran salto hacia la pintura no representativa.

Malévich vive la represión zarista y la revolución frustrada de 1905. La insatisfacción de la clase obrera, que es el motor de la economía agraria, da lugar a constantes manifestaciones contra la burguesía y los zares. La más célebre es el Domingo Rojo -también conocida como Domingo Sangriento-, donde la carga masiva contra obreros ocasiona un gran número de víctimas y la inevitable ira popular, que, bajo la orquestación de Lenin, se erige en una poderosa fuerza contra la maquinaria represiva. Sin embargo, es la Primera Guerra Mundial (1914-1918) el detonante de una insatisfacción popular que acaba causando el estallido de la revolución definitiva, en 1917. ${ }^{139}$

Estos procesos revolucionarios exigen una redefinición radical de los contenidos y la inevitable transición en el panorama artístico hacia doctrinas místicas. Esta intención, con la que Malévich coquetea a través del suprematismo, surge asociada a una nueva visión suprema alejada de la tradicional significación y comprensión lógico-racional de las formas. Esta nueva forma artística se podría definir como "arte no-figurativo con sentido no-objetivo".

Tras recorrer los distintos movimientos artísticos, Malévich decide explorar las formas geométricas puras y la relación entre ellas (base artística y filosófica del suprematismo). En 1915 se inaugura la exposición 0.10, La última exposición futurista, donde exhibe su icónico Cuadro Negro, y también el manifiesto Del cubismo y el futurismo al suprematismo ${ }^{140}$, donde explica los

\footnotetext{
139 Victor Serge, "Capítulo Primero: De la servidumbre a la revolución proletaria," en El año I de la Revolución Rusa (México: Siglo Veintiuno Editores, 1999).

140 El Manifiesto del suprematismo de Malévich y su grupo UNOVIS, de 1924, dice: «EI arte del presente, y de la pintura en particular, ha triunfado en todo el frente. La conciencia ha superado la superficie plana y ha avanzado hacia el arte de la creación espacial. A partir de ahora la pintura de cuadros queda para aquéllos que, pese al esfuerzo infatigable de su conciencia, no han logrado liberarse de su superficie, para aquéllos cuya conciencia ha continuado siendo plana porque no han podido superar la superficie plana. (...) La nueva morada del hombre se encuentra en el espacio. La tierra se convierte para él en una estación de tránsito y de acuerdo con ello deben construirse aeropuertos que se adapten a los aviones y, por tanto, estén desprovistos de arquitectura columnasta. Las viviendas provisionales de los nuevos hombres deben adaptarse a los aviones,
} 
valores del arte suprematista y sus pinturas elevadas a nuevos iconos del arte no-figurativo: "Me he transformado en el cero de la forma y emerjo de la nada a la creación, esto es, al suprematismo, al nuevo realismo de la pintura: la creación no-objetiva."141

El suprematismo surge de un irrefutable cansancio del adorno, de un descrédito continuo de lo visible y de la mirada que lo contempla. Se busca la abstracción de la forma y del color, una invisibilidad que eleve al ser a la espiritualidad; una "purificación" del arte exaltada por Malévich, que hace que gran parte de los artistas quieran "remontarse, en el plano de la expresión, al mítico punto cero: el de la elocuencia desnuda, no asistida por la retórica o el artificio del estilo". ${ }^{142}$ Su obra encarna el extremo de la depuración visual, la búsqueda insistente del grado cero de la representación, de un arte que se relacione con el sentimiento, y no con su comprensión lógica.

Con anterioridad a Malévich, nombres como Paul Cézanne, Vasili Kandinsky, Piet Mondrian, y, más tarde, Paul Jackson Pollock abren en la pintura el camino a la abstracción y a todo lo que se puede ver en lo invisible; una filosofía absolutamente opuesta a la mítica Caverna de Platón, en la que, según Jacques Rancière, "aquel que ve no sabe ver."143

Kandinsky, a quien se le atribuye el inicio de la abstracción consciente, habla de una nueva manera de contemplar un cuadro, sin la tiranía de los sentidos y guiándose por la desconfianza de lo visible y de la validez óptica. ${ }^{144}$ Con esta nueva corriente se llega a un momento del panorama artístico en el que, como defiende Javier Seguí; "ya no importa propiamente representar; importa saber lo que significa." 145

tanto en el espacio como en la tierra. Una casa así creada también se conservará mañana. Por ello, los suprematistas proponemos los planetas sin objeto como base para la realización colectiva de nuestro ser. Los suprematistas buscaremos aliados para luchar contra las formas anticuadas de la arquitectura. (...)¡Deseamos crear nuevas relaciones para el medio actual, relaciones que no se desarrollan sobre el plano de la antigüedad, sino sobre el plano del presente, del día de hoy! Consideramos liquidada la forma de las manifestaciones pictóricas estetizantes. El suprematismo concentra ahora sus esfuerzos en el frente de la arquitectura y llama a todos los arquitectos revolucionarios para que se unan a él.» En: Pere Hereu Payet, Josep Maria Montaner, and Jordi Oliveras, Textos de arquitectura de la Modernidad, trad. José Galán José Luis Gil Aristu, Ricardo Zayas y Joaquín Rodríguez (Madrid: Editorial Nerea, 1994), 220.

141 Ana Moreno, "Vanguardias rusas," ed. Fundación Colección Thyssen-Bornemisza (Madrid1989), 26.

142 Álvaro Delgado-Gal, Buscando el cero. La revolución moderna en la literatura y el arte (Madrid: Taurus, 2005), 249.

143 Jacques Rancière, El espectador emancipado, trad. Ariel Dilon (Buenos Aires: Editions Manantial, 2010), contraportada.

144 Hernández-Navarro, "El cero de las formas. El cuadro negro y la reducción de lo visible," 128.

145 Seguí, 8 de abril, 2014. 
En una visión más atrevida, el mismo afirma que, mucho antes de Kandinsky, ya El Greco en el final del siglo XVI permite intuir una representación más allá de lo visible; después de siglos de olvido, recientemente se reconoce al pintor de origen griego como precursor de la Modernidad. El Greco y su manierismo radical influyen en artistas vanguardistas como Cézanne o Picasso al dar a la iluminación un sentido que va más allá de lo estético.

El pintor transforma lo invisible en algo visible, confiriendo a la pintura el papel de ciencia especulativa:

Aquí se plantea por vez primera de forma "especulativa" un nuevo método de descubrir una visión nueva, llena de audacia y licencia poética, y de su constante innovación, intentando liberarla decididamente incluso de la condición limitada de su propia imaginación, que no va más allá del sentido común. ${ }^{146}$

Dentro de esta "limpieza ideológica", también François Jullien, sinólogo francés especialista en cultura china y oriental, escribe un ensayo titulado Elogio de lo insípido, que, a juicio de Javier Seguí, resulta inspirador y definitivo para la comprensión de esta cuestión. En este breve ensayo, Jullien explica que a través de lo insípido se llega a la esencia de todas las cosas. Para el autor, sólo cuando los sabores dejan de oponerse entre sí y se liberan de la huella sensitiva, se puede vislumbrar la verdad en su plenitud. No se trata de aislar los sentidos, sino de despojarlos de todo lo que los hace más turbios.

Como el silencio y el vacío son el fundamento de la música y de la plástica, lo insípido es el suelo donde descansa el gusto. Lo insípido tiene algo de goce hastiado, de allanamiento del gusto, de aburrido sentir que espera un sobresalto. ${ }^{147}$ (...) Es más importante el silencio que lo que se dice. ${ }^{148}$

En Occidente, donde priman los sentidos y la significación, elogiar el silencio, el vacío o lo insípido es una provocación arriesgada y una incitación a la cólera de los menos preparados. Para los chinos, la palabra "insipidez" ("dan") significa, además, "desapego", sinónimo de liberación de ataduras, la única manera de alcanzar la tranquilidad y el sosiego; es cualidad del centro y de la base. Por ese motivo Cage, que bebe de la cultura musical india, busca en ese centro la tranquilidad con el objeto de "acallar su voz para abrirse a todos los sonidos." ${ }^{149}$ En ese mismo centro

146 Yasunari Kitaura, "Segunda Parte," en El Greco. Génesis de su obra (Madrid: Consejo superior de Investigaciones Cientificas, 2003), 84.

147 Seguí, Dibujar, proyectar (IX) - El grado cero de la arquitectura.

148 Seguí, 28 de octubre, 2014

149 Carmen Pardo Salgado, "Las formas del silencio," Universidad de Catilla-La Mancha,16 de dic. de 2014, https://www.uclm.es/artesonoro/olobo3/Carmen/Formas.html. 
Jullien encuentra la insipidez y el desapego a esos sentidos que nos informan del mundo de una manera variable y relativa.

\author{
Decir no tiene sentido. El silencio. \\ Decir el silencio y verlo. Amordazado. \\ Sólido y denso. \\ Decir el sentir, sintiendo. \\ Sentir el decir sin sentimiento. \\ Un hueco perfecto, cúbico. \\ Vacío y lleno. ${ }^{150}$
}

La insipidez de la que habla Jullien ayuda a distanciarse del mundo esclavizado por los sentidos, algo de lo que también se hace eco el escritor inglés Aldous Huxley en su famoso ensayo Las puertas de la percepción, un libro inspirado en la célebre frase de William Blake: "Si las puertas de la percepción se depurasen, todo aparecería a los hombres como realmente es: infinito. Pues el hombre se ha encerrado en sí mismo hasta ver todas las cosas a través de las estrechas rendijas de su caverna." ${ }^{151}$

En este ensayo epistemológico, Huxley defiende que las drogas son un importante vehículo para eliminar la esclavitud impuesta por los sentidos. Mediante el uso del "peyote"152 el escritor pretende provocar cambios en las frecuencias cerebrales con el objeto de alterar la percepción y ampliar la conciencia de su entorno.

En su opinión, bajo el efecto de esta droga se percibe lo cotidiano de otra forma. Dimensiones como el espacio y el tiempo encuentran en el color una manera trascendente de abordar una cantidad impresionante de sensaciones que pueden llegar a agotar al individuo. Por este motivo, según el autor, el filtro de los sentidos sirve para proteger al ser humano de una realidad para cuya experimentación no está preparado.

También en la película Matrix, a semejanza del ensayo de Huxley, los sentidos son los responsables de mantenerlos atrapados en un mundo donde la mirada debe "aceptar lo que ve" y lo que "han puesto sobre los ojos para cegarnos de la verdad". ${ }^{153}$

Es importante entender cómo este nuevo engranaje ideológico

\footnotetext{
150 Fullaondo, "Javier Segui (1964-1983)," 23.

151 Aldous Huxley, Las puertas de la percepción. Cielo e infierno., trad. Miguel Hernani (Barcelona: Edhasa, 2009).

152 Savia de un cactus utilizada por los indios mexicanos, a partir de la cual se extrae la mezcalina.

153 Matrix, Andy Wachowski y Lana Wachowski, (USA: Warner Bros, Village Roadshow

Pictures, Groucho II Film Partnership, 1999), DVD
} 
se extiende a todos los ámbitos artísticos con nuevas formas de expresión alejadas de las ideologías tradicionales. Tomando como punto de partida la revelación de Barthes, en todos los campos artísticos se pone de manifiesto la necesidad del alejamiento del signo:

Cuando la literatura empieza a fijarse no tanto en la historia que cuenta, sino en el modo de juntar las palabras. Literatos radicales en este sentido son Valéry, Mallarmé. Y en pintura pasa lo mismo. Cuando el arte se da cuenta de que no le interesa nada representar, no quiere copiar cosas que se parezcan a cosas. Quiere explorar otra cosa. Entonces, al explorar otra cosa, abandonas todas las reglas, y actúas como si fueras un niño pequeño. ${ }^{154}$

En ese sentido, también la escultura se imbuye de estas nuevas tendencias artísticas. Uno de los maestros de ese cambio es, de acuerdo con Javier Seguí, Jorge de Oteiza, que sabe dar forma a lo que cuatro siglos antes ya intuyera Miguel Ángel Buonarroti.

Oteiza descubre que hay dos formas de hacer escultura: añadiendo cosas - poniendo una detrás de la otra, juntándolas- y quitándolas. ${ }^{155}$ Igual que el silencio de Cage, también el vacío de Oteiza expresa lo más importante de su obra. Para éste, el acto fundador del arte está asociado a su destrucción.

En su libro más determinante, Quosque Tandem...! Ensayo de interpretación estética del alma vasca ${ }^{156}$, Oteiza materializa su ideal de libro escultórico. Según el filósofo catalán Amador Vega, Oteiza abandona la escritura lineal y la dota de una nueva dimensión tridimensional, escultórica, que se puede ver desde distintos ángulos. En Quousque Tandem, lo estético se confunde con lo antropológico, y su misticismo se revela en un centro semejante a lo que Jullien y Cage descubre en sus obras. Un centro vacío al estilo del crómlech ${ }^{157}$ vasco, que busca la forma universal. El

\footnotetext{
154 Seguí, 28 de octubre, 2014.

155 Seguí, 8 de abril, 2014.

156 Libro escrito por Jorge de Oteiza en 1963, cuatro años después de dejar su trabajo escultórico por considerarlo acabado. El título, que se deriva de la frase ¿Hasta cuándo abusarás, Catilina, de nuestra paciencia? («Quousque tandem abutere, Catilina, patientia nostra?»), recoge las palabras pronunciadas por Cicerón contra Lucio Sergio Catilina, político romano acusado de conspirar contra la República.

157 El crómlech (piedra plana colocada en curva, según el galés antiguo) es un monumento megalítico dispuesto en el suelo de forma circular, cuya función podría estar relacionada con ritos fúnebres o sagrados. Quizá fuesen lugares de reunión para la comunidad o, según algunos, lugares donde el ser humano contempla el firmamento. Para Oteiza, el crómlech es el símbolo de todo lo figurativo transformado en abstracto y, como él mismo dice: «que todo se haya vuelto figurativo y no quede más que como señal que todo ha concluido, lo único que por naturaleza es naturaleza abstracta, la nada como absoluto -suelto de todo el cero final de un silencio visual vacío». En: Otei-
} 
estilo "no-estilo". Un modo de "andar que es un "desandar"158, donde el vacío es el objetivo final del proceso.
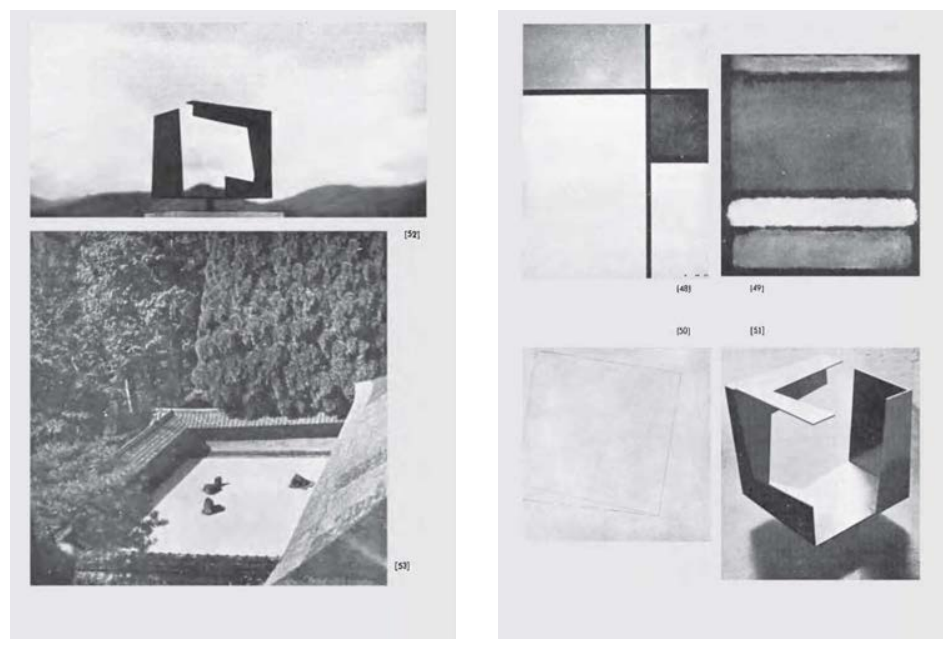

ILUSTRACIONES DE JORGE DE OTEIZA - Ilustraciones 48-53, donde se combinan, a doble página (de arriba abajo y de izquierda a derecha): composición de Mondrian (1932); pintura de Rothko (1957); Cuadro blanco sobre fondo blanco, de Malévich (1918); el Mueble metafísico $n^{\circ} 1$, de Oteiza (1958); un vacío estético (espacio religioso) y Naturaleza, con escultura de Oteiza (1958); y un jardín de piedras en Kioto.

La poética de Oteiza, como asevera Vega, nace de la voluntad de "desocupar el vacío"; de la búsqueda del silencio puro, donde la "nada es el todo"; una especie de estética negativa que trata de eliminar el propio lenguaje.

(...) se refiere al procedimiento de actuar creadoramente por sucesivas negaciones, en una serie progresiva de eliminaciones, fenomenológicamente, reduciendo entre paréntesis todo aquello que debemos apartar para aislar el objeto verdadero o la acción que perseguimos. ${ }^{159}$

Más adelante, en su libro se puede consultar su Breve diccionario crítico comparado del arte prehistórico y el arte contemporáneo. En él se halla un interesante análisis del concepto de "cero":

La evolución de los lenguajes se produce partiendo (la expresión) de cero, y volviendo al cero. Equivale técnicamente a contar y a descontar: lo que se cuenta en la primera fase se descuenta en la segunda. Si una pintura es en la primera fase la técnica de cubrir una superficie, en la segunda es la técnica de des-cubrirla. El cero final es des-cubrimiento así trascendente, cuando el artista es responsable de su investigación. ${ }^{160}$

4 za, Quousque Tandem...! Ensayo de interpretación estética del alma vasca.

158 Oteiza, Quousque Tandem...! Ensayo de interpretación estética del alma vasca, 34.

159 Oteiza, Quousque Tandem...! Ensayo de interpretación estética del alma vasca, 37.

160 Oteiza, Quousque Tandem...! Ensayo de interpretación estética del alma vasca, 40. 
Oteiza reivindica al artista fuera del arte, pero dentro de la vida -el agur vasco sirve tanto para saludar como para despedir-; un arte que no se encuentra en los museos, sino dentro de uno mismo; un arte donde el lenguaje es el grado cero de la comunicación, la pura "incomunicación", la página en blanco.

Hablan en contrario de la página en blanco cuando se ponen a pensar o escribir. Con terror a la página en blanco. Yo, la única felicidad que siento, es cuando veo la página en blanco y dejo dos palabras. Tres. Y empiezo a combinar. Lo mismo que he hecho en escultura. Combinaciones binarias. Ternarias. Surge la metáfora. Surge todo. Yo soy feliz. ${ }^{161}$

Envuelto en estos universos simbólicos, Oteiza considera que la actividad artística está agotada, y por ello en 1959 da por concluida su experiencia como escultor. Según su punto de vista, al artista sólo le queda la cotidianidad; y sobre el arte actual Oteiza afirma, incluso, que los nuevos artistas están condenados a la "sujeción de un mercado", al "narcisismo" y a la "ausencia de contenidos":

Se construyen edificios monumentales destinados a poner de relieve la habilidad del arquitecto subordinado a la corporación o institución que lo ha patrocinado. Son así tan sólo símbolos de poder económico o político. Y entonces la arquitectura espectacular generada por las directrices de mercado no sirve ni para cubrir las necesidades materiales de la mayoría ni para transmitir un código de valores mínimo. ${ }^{162}$

También Javier Seguí comparte ese mismo sentimiento de rabia hacia la arquitectura actual de los "arquitectos-superestrella", que no sostiene un lenguaje coherente, que confunde los ámbitos, los contextos y la envolvencia.

Hace algún tiempo que ya no me interesa la arquitectura como profesión. Me abruma y me angustia el papel del arquitecto que sabe que la edificación es un derecho de la gente (de los usuarios), un negocio de los promotores y una profesión artística del que proyecta e intenta controlar la construcción de lo proyectado. Además, como profesor universitario y como ciudadano involucrado en la cultura colectiva, asisto a la desaparición objetiva de la arquitectura, que se sume sin remedio en la invisibilidad producida por la pérdida de su significación. ${ }^{163}$

\footnotetext{
161 "Jorge De Oteiza (in Memoriam)." Youtube. 21 de diciembre de 2014, https://www. youtube.com/watch?v=roSpmxOW1VU.

162 Andoni Alonso and Iñaki Arziz, "Oteiza Y La Arquitectura," en Jorge Oteiza. Arte y pensamiento (Donostia: Editorial Cibergolem, 1996), 46.

163 Seguí, Dibujar, Proyectar (IX) - El grado cero de la arquitectura, 29.
} 
Afirma Rancière que en estos momentos se debería estar viviendo un asombroso momento artístico pero, "hoy tiende a ser más bien de algunos egos artísticos sobredimensionados o una forma de hiperaticivismo consumista, cuando no ambas cosas a la vez." 164

El creciente dominio de la vista hace que muchos proyectos arquitectónicos modernos no sean más que ejemplos de vanidad que transforman la arquitectura en "un juego intelectual y artístico separado de las conexiones mentales y sociales fundamentales". ${ }^{165}$ Una arquitectura meramente visual, indiferente al cuerpo que "tiende a alejar la visión de la participación e identificación emocional y a convertir la imaginería en un flujo fascinante sin centro ni participación." ${ }^{166}$

Oteiza dirige feroces críticas al Guggenheim, del arquitecto canadiense Frank $O$. Gehry, por la opulencia provocativa de su edificio. Como dice Rafael Moneo:

Tal vez sea la obra de Oteiza, al margen ya de todo vaivén temporal, la última página de una historia apasionante: la historia de aquellos hombres que creyeron posible prescindir del lenguaje establecido, de todo el mundo heredado de convenciones, para dar forma a una nueva vida. ${ }^{167}$

De forma similar al modo de entender la escultura de Oteiza, la arquitectura también puede concebirse como un "quitar cosas", como ese "cero-crómlech", esa desocupación del vacío como ensayo del espacio arquitectónico; una arquitectura que lucha contra el lenguaje convencional y que encuentra en el vacío su propia esencia. Una arquitectura metafísica que, como el arte, "debe cumplir hoy con las funciones antes asignadas en la religión a las órdenes espirituales, como los franciscanos en Occidente o los budistas en Asia." 168

Incidiendo en la ideología oteiziana, Javier Seguí añade que lo arquitectónico no se refiere a la construcción o el cascarón del edificio, sino a ese interior donde el vacío lo abarca todo: "arquitectura neutra, insípida, que persigue su autodestrucción como objeto, que busca el fundamento que organiza la significación de la envolvencia. A lo que queda cuando la arquitectura desaparece o está a punto de desaparecer." ${ }^{169}$

\footnotetext{
164 Rancière, El Espectador Emancipado, 27.

165 Juhani Pallasmaa, Los ojos de la piel, trad. Moisés Puente (Barcelona: Editorial

Gustavo Gil, 2006), 21.

166 Juhani Pallasmaa, Los ojos de la piel, trad. Moisés Puente (Barcelona: Editorial

Gustavo Gil, 2006),122.

167 Alonso and Arziz, "Oteiza y la arquitectura," 39.

168 Alonso and Arziz, "Oteiza y la arquitectura," 23.

169 Seguí, Dibujar, proyectar (IX) - El grado cero de la arquitectura, 3.
} 
Siguiendo esta línea inmaterial, Javier Seguí cita al artista plástico norteamericano James Turrell como el artista-arquitecto que, igual que Oteiza, sabe conferir al espacio arquitectónico una nueva dimensión. Para Turrell, la luz del espacio es lo más importante de un edificio, pues le confiere esa "especie de ilusión espacial ambiental que no tiene materia". ${ }^{170}$

Las referencias de Javier Seguí a Turrell se remontan a los años setenta cuando, estando en un piso en Madrid, Palazuelo le pide que cierre los ojos y escuche el silencio. Esta abrumadora experiencia permite que Seguí, al igual que el rey de Bajo el sol jaguar ${ }^{171}$, de Italo Calvino, viva el espacio con todo el cuerpo:

De esta iniciativa nacieron una pedagogía del dibujar que denominamos "las figuras de la luz" y un entendimiento de lo arquitectónico desde sus constituyentes internas más básicas (ambientales y dimensionales), que denominamos "El grado cero de la arquitectura". ${ }^{172}$

En 2004 Javier Seguí empieza a llevar a cabo sus primeras experiencias pedagógicas alrededor del grado cero. Turrell, al que conoce personalmente en una exposición en La Caixa en noviembre de 1992, pasa a ser una referencia de suma importancia en la búsqueda de una nueva pedagogía en la arquitectura.

En palabras de Seguí, "Turrell es un inventor de recintos que son una trampa donde se atrapa la luz, en el seno de la oscuridad o la penumbra." Según relata, Turrell "configura lugares radicales dentro de los cuales, sin nada que hacer y con poco o nada que mirar, se provoca un acomodo situacional (cognitivo y perceptivo) del espectador, que desencadena en él una actividad fenoménico-metafórica excepcional." 173

Turrell, el "arquitecto" de espacios paradigmáticos, donde el silencio y la oscuridad niegan los límites de la percepción y conducen a una extrañeza radical; experimenta lo arquitectónico materializado en poesía. Sólo la ausencia de luz es capaz de construir espacios de ensoñación, la penumbra disuelve las fronteras exterior-interior, sólo ella puede iluminar la mente y hacer que la arquitectura muestre su "arquitectónico poético más radical". ${ }^{174}$ En sus trabajos, donde se hace patente el conocimiento sensorial, Turrell expresa la voluntad de crear una obra atemporal,

170 Seguí, 8 de abril, 2014.

171 Italo Calvino, Bajo el sol, trad. Aurora Bernandéz (Barcelona: Tusquets Editores, 1989).

172 Seguí, Dibujar, proyectar (IX) - El grado cero de la arquitectura, 23.

173 Seguí, Dibujar, proyectar (IX) - El grado cero de la arquitectura, 23.

174 Seguí, Dibujar, proyectar (IX) - El grado cero de la arquitectura, 24. 
alejada del objeto y enfocada en la experiencia espacial; un arte que, como la matemática, es totalmente estético:

No creo que mi trabajo es ciencia, pero creo que es expresión del conocimiento. ${ }^{175}$

Estoy interesado en el arte de no-imagen porque quiero crear algo que te conecta directamente con un pensamiento que es sin palabras, un pensamiento que no tiene una línea argumental. Es ahí que encuentro significado. Es como una demostración matemática o un problema en la teoría de conjuntos. Es un espacio de pensamiento que tiene una especie de soledad, pero también una gran belleza. ${ }^{176}$

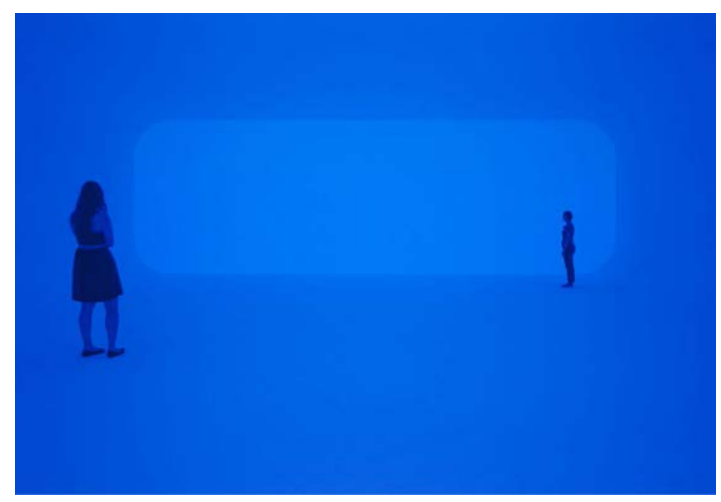

JAMES TURRELL: A RETROSPECTIVE (2013-2014. Exposición celebrada en el Angeles County Museum of Art: "Explora casi cincuenta años en la carrera de James Turrell, un artista clave en la Luz del sur de California y el movimiento espacial de la década de 1960 y 70. La exposición incluye primeras proyecciones geométricas de luz, grabados y dibujos, instalaciones que exploran la privación sensorial y campos aparentemente no moduladas de color claro y reciente trabajo bidimensional con hologramas." 177

La poética de la luz de Turrell sólo se puede igualar a La llama de una vela ${ }^{178}$, de Bachelard, donde también la luz -en este caso, la llama de la vela- es un "operador imaginario" de altísima magnitud. En el prólogo de su libro, el escritor afirma:

La llama es entre los objetos del mundo que convocan al sueño, uno de los más grandes productores de imágenes. La llama nos obliga a imaginar. La llama lleva a los más diversos dominios de la meditación, su carga de metáforas e imágenes. ${ }^{179}$

\footnotetext{
175 Craig Adcock, "Introduction," en James Turrell: The Art of Light and Space (Los Angeles: University of California Pres, 1990), XX.

176 Adcock, "Introduction," en James Turrell: The Art of Light and Space, XX.

177 (Los Angeles County Museum of Art) LACMA, "James Turrell: A Retrospective," 2013, 4 de febrero de 2015, http://www.lacma.org/art/exhibition/james-turrell-retrospective.

178 Gastón Bachelard, La llama de una vela, trad. Hugo Gola (Monte Avila Editores, 1975).

179 Bachelard, La llama de una vela, 9.
} 
En esta línea de despojamiento material, Javier Seguí hace alusión a las favelas de Brasil como el más radical de los ejercicios arquitectónicos, el ejemplo superlativo de la arquitectura de grado cero. ${ }^{180}$ Construcciones espontáneas, que nacen de la intuición y del reciclaje sin un planteamiento previo; construcciones que parten del mismo caos y del mismo azar que Cage y Joyce emplean en sus creaciones; edificios que crecen ajenos al capital, sin ninguna intención estética y "donde la forma arquitectónica se legitima como extensión del cuerpo"181. También lo entiende así el arquitecto mexicano Danilo Veras Godoy, para quien, como confiesa Seguí, "ni todos los planos arquitectónicos sirven para definir a detalle el proyecto... una cuestión gestual es más cercana a lo real, que algo que está a escala."182

Danilo Veras hace arquitectura sin planos, sin memorias ni licencias de obra. "Su sistema era directo, artesanal y muy fácil de comprender por los operarios"; ${ }^{183}$ sus casas "parlantes" coinciden con el movimiento inesperado de sus manos, generando espacios sensoriales y bien integrados en el medio; su arquitectura es "táctil, para ser tocada, y está realizada artesanalmente con las manos"184; una arquitectura "radicalmente expuesta a la visualidad, pero difícilmente explicable desde las practicas grafico-geométricas visuales convencionales". ${ }^{185}$

Sus edificios trascienden las convenciones y los estereotipos de la arquitectura tradicional y moderna; la "escritura sin escritor", de la que habla Barthes, se refleja en esta "arquitectura sin arquitecto", que Danilo Veras improvisa en su "no-estilo" como estilo.

Como nos comenta el arquitecto mexicano Juan Palomar, "Danilo era un raro, era alguien que se salía de los estándares convencionales de la arquitectura y que tenía una pasión que le desbordaba por hacer cosas que a él le fueran importantes."186

Este hombre tiene mucho que ver con la imaginación constructiva directa. Es imaginar las cáscaras en función de sus propios movimientos del cuerpo. $Y$ algunos elementos fijos en el terreno. Arrancaba y empezaba a construir sin planos. Lo iba construyendo a cachos. No hacía obras para ricos, sino que eran obras para gente... Entonces cada año construían un cachito. Cuando se le acababa el dinero paraba,

\footnotetext{
180 Seguí, 8 de abril, 2014.

181 Angelique Trachana, "El grado cero de la arquitectura," Ega 18 (2013): 142.

182 Seguí, "Danilo Versas Godoy. Arquitecto 1949/2007".

183 Seguí, Dibujar, proyectar (IX) - El grado cero de la arquitectura, 5.

184 Seguí, Dibujar, proyectar (IX) - El grado cero de la arquitectura, 6.

185 Javier Seguí, Dibujar, proyectar (XXXIV) - Danilo Veras (Madrid: Instituto Juan Herrera de la Escuela de Arquitectura de Madrid, 2011), 11.

186 Juan Palomar Verea, entrevistado por Maria Brito, 6 de febrero, 2015.
} 
y el próximo año ya le ocurría otra cosa. Este personaje era fantástico. ${ }^{187}$

Su reconocida singularidad hace que sea el protagonista de la Exposición de la Bienal Iberoamericana de Arquitectura y Urbanismo 2008, celebrada en Lisboa un año después de su muerte. La exposición, a cargo, entre otros, de Javier Seguí, narra la singularidad irrepetible de la arquitectura de Danilo Veras, fácilmente vinculada a nombres como el arquitecto catalán Antoni Gaudí o el mexicano Juan O'Gorman. El arquitecto deja un vasto legado de obras de extrema sensibilidad y respeto al entorno natural, lo que constituye una pista fundamental para entender la admiración y empatía que despierta.

Merece la pena destacar el asombro que Danilo Veras provoca en todos los que presencian su manera de proyectar in situ. El uso del cuerpo como marco del dibujo no deja indiferente a nadie. Su amigo personal, el arquitecto Ricardo Miranda, afirma que " ¿Danilo gusta de hacer planos estructurales in situ escala 1:1, como si estuviéramos en el siglo XVIII!"188

También el arquitecto Roberto Goycoolea Prado comenta que, en la arquitectura de Danilo Veras "no hay plantas ni detalles previamente medidos y presupuestados. Los maestros de obra, forjados junto al arquitecto, plasman sus palabras, gestos y algún efímero bosquejo directamente en la materia y el espacio."189

Con la misma admiración Juan Palomar relata:

(...) lo que más me impresiona y lo que mejor guardo de ese día es la manera, más de lo que yo pude ver de la obra, de cómo Danilo la describía y la proponía como una solución a sus búsquedas más interiores. Entonces era como un juego de mímica, de expresiones corporales, de gestos con los que iba describiendo y mostrando lo que quería hacer con la casa. Abarcaba con los brazos los espacios, esculpía en el aire los niveles, las vistas. Él hablaba de los materiales como se habla de amigos queridos (...). Y lo que uno estaba viendo ahí era una corporeización de lo que Danilo quería hacer, pero que al ser descrito por él, al ser mostrado por él, adquiría una calidad extraordinaria, inolvidable. (...) Y regresando a la manera como estaba construyendo y pensando su casa era algo absolutamente corporal, algo físico, inclusive erótico. Esta manera de acariciar las paredes, de sobar las escaleras, de reír como un niño cuando logra lo que quiere. ${ }^{190}$

187 Seguí, 20 de mayo, 2014.

188 Seguí, "Danilo Versas Godoy. Arquitecto 1949/2007".

189 Seguí, "Danilo Versas Godoy. Arquitecto 1949/2007".

190 Verea, 6 de febrero, 2015. 

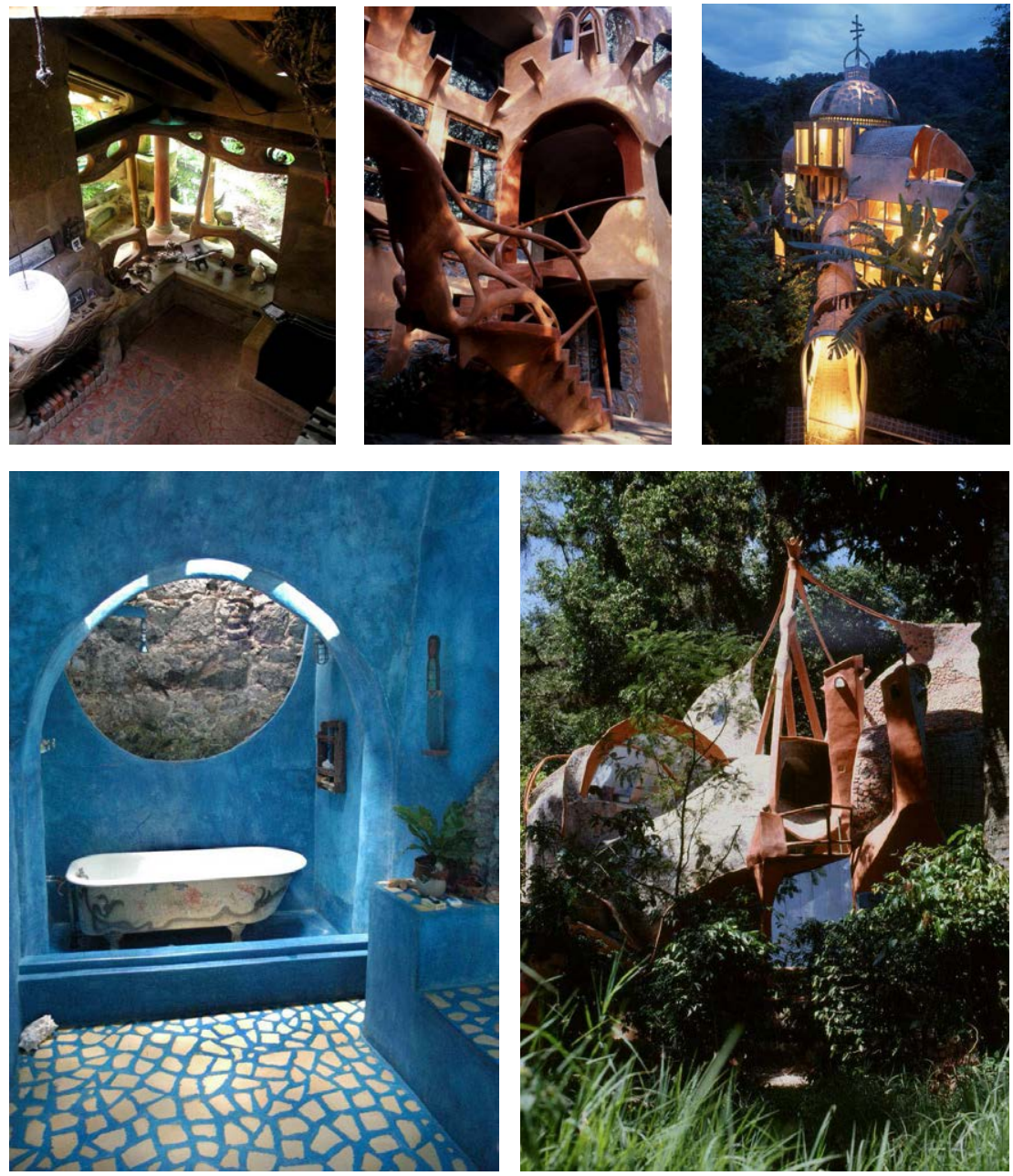

CASAS UNIFAMILIARES DE DANILO VERAS GODOY EN MÉXICO. Estas fotografías forman parte del catálogo de la Exposición de la Bienal Iberoamericana de Arquitectura y Urbanismo 2008, dedicada a Veras Godoy.

Para Javier Seguí, Danilo es "quizá el último arquitecto feliz". ${ }^{191}$ De él habla con especial admiración, y menciona el uso de su cuerpo como herramienta principal de trabajo:

Asombrado, vi (de lejos) a Danilo gesticulando con todo su cuerpo, como danzando. Tomé posiciones y entendí que Danilo explicaba a la propietaria su proyecto, dibujando en el aire las divisorias, los pasos, los techos, etc. Es decir, los componentes materiales de lo que él creía debía ser el contenido de su intervención. Danilo tocaba y acariciaba con sus manos superficies verticales o inclinadas inexistentes, mientras daba pasos con el cuerpo estirado o torcido haciendo ver las curvaturas o los cortes de los paños que habrían de construirse. Danilo actuaba como los mimos que hacen el si- 
mulacro de tocar cosas inexistentes, o como un escultor que se moviera en la nada tal como lo haría contra la materia que constituiría su obra. ${ }^{192}$

Danilo Veras logra alejarse de todo sistema académico y de las convenciones clásicas, y pone de manifiesto una arquitectura más antropológica y fisiológica que la actual estética desarrollada bajo convenciones burguesas. ${ }^{193}$ Como él mismo confiesa, es muy importante su cuerpo como "modulor", como sistema métrico del espacio porque, tal como cuenta, "diseño y construyo dibujando en el aire con varillas con las que defino el espacio imaginado y consigo las primeras formas a partir de diferentes puntos de vista hasta conseguir relaciones formales armoniosas entre sí y su entorno." 194

Para entender la arquitectura, Javier Seguí recuerda que es fundamental percibir su integración dinámica en las artes. En ese sentido menciona a Muntañola y su visión de la arquitectura como experiencia colectiva. "La mejor enseñanza de la arquitectura tiene que ver con hacer teatro, con la dialógica, con el dejar al otro existir. Pensar que tienes que fabricar el medio para que el otro esté a gusto." 195

También en el teatro y en el cine se lucha contra la supremacía burguesa y la producción capitalista. Su limpieza conceptual pasa fundamentalmente por relegar la caracterización del personaje. El teatro del absurdo, por ejemplo, ve nacer al personaje sin carácter, sin nombre propio, sin estereotipo, sin la dictadura de la imagen oprimida por los textos dramáticos. El vacío absoluto en búsqueda de lo que todavía queda por decir.

En España pervive durante mucho tiempo el concepto del realismo clásico; un teatro conservador donde la "mirada pasiva por parte del espectador (...) asume demasiado fácilmente las reglas del juego dramático sin que la representación altere su visión de sí mismo en la sociedad." 196

Parece necesario un teatro que libere la imaginación, donde no se induzca, sino que se invite al espectador a pensar; se necesita un cambio radical en la manera de ver y de hacer las artes escénicas, que lo protagonizan, a principios del revolucionario siglo XX, artistas como el británico Edward Gordon Craig y el

\footnotetext{
192 Seguí, Dibujar, proyectar (XXXIV) - Danilo Veras, 22.

193 Trachana, "El grado cero de la arquitectura."

194 Seguí, "Danilo Versas Godoy. Arquitecto 1949/2007".

195 Seguí, 20 de mayo, 2014.

196 Alberto Mira Nouselles, "Realismo clásico: ¿Grado cero de la representación?," en

De silencios y espejos - Hacia una estética del teatro español contemporáneo (Valencia:

Universitat de Valencia, 1996, 1996), 129.
} 
arquitecto y escenógrafo suizo Adolfo Appia. De ellos Javier Seguí comenta:

Edward Gordon Craig es, junto con A. Appia, un innovador teatral. Actor, teórico, autor, escenógrafo, divulgador... Viene aquí bien porque es el inventor de la instalación cambiante y expresiva, el descubridor de la "caja vacía sometida a la luz" como espectáculo autónomo. Siempre hemos visto en Craig una subterránea conexión con J. Turrell que no conocemos haya sido señalada por nadie. ${ }^{197}$

Javier Seguí conecta el singular lenguaje lumínico de Turrell con el re-significado de la caja escénica de Craig y el movimiento lumínico que le imprime, aunque matiza diciendo:

Gordon Craig no paraliza la luz como Turrell, sino que la mueve para componer una danza con sus figuras mientras que Turrell aquieta la luz en el vacío de sus escenas trampas, o deja que se muevan con extrema lentitud, agigantando la sensación de asombro extrañado de un espectador situado dentro del escenario. ${ }^{198}$

Un nuevo espacio que, al igual que la arquitectura de Danilo Veras Godoy, no se explica ni se enseña; se intuye, se revela. Un espacio mágico que recupera Turrell años más tarde asumiendo la luz como protagonista y diluyendo los límites con su ausencia.

Craig juega con la penumbra y con la sombra, que son los elementos que llenan la caja volumétrica escénica de expresividad mundana. Más tarde, después de la Gran Guerra y en el radical límite de su concepción teatral, Craig piensa que el sólo vacío escénico bajo el juego de la luz es capaz de hacer ver y revelar lo inexplicable, que es de lo que se trata en el arte del teatro. ${ }^{199}$

Con Craig, el teatro realista, hasta este momento literario, gana gestos y movimientos. Su propuesta pretende sustituir el palco estático por uno cinético y, de forma innovadora, aboga por que la luz sea vertical en relación al palco, pero también al fondo de la sala; Craig rechaza el realismo en pro de la esencia de la obra ${ }^{200}$; reivindica un nuevo teatro que se esconde detrás de la cotidianidad. Para ello defiende el uso de la fuerza simbólica y estética de una escena cada vez más poética y plástica. Los símbolos son la sal de la vida: los símbolos del alfabeto, los musicales, los científicos, los matemáticos, los religiosos, la numismática; todas las culturas están llenas de símbolos, porque el símbolo es la propia vida. 
Para Craig, el teatro no es ámbito para un músico, ni para un pintor o un escritor, pues ellos contaminan la escena; son inútiles en el teatro. Sólo el movimiento silencioso puede desvelar imágenes poéticas -mediante la danza- o imágenes en prosa -mediante el gesto-. Para Craig, como también para Danilo Veras, todo nace a partir del movimiento:201 "Me gusta recordar que toda cosa brota del movimiento, también la música; me gusta pensar que será nuestro supremo honor ser los ministros de esta fuerza suprema: el movimiento."202

En relación a una total limpieza de las convenciones tradicionales, Craig expresa: "creo en el tiempo en que estaremos en grado de crear obras de arte en el teatro sin el uso de los textos escritos, sin servirnos de actores." 203

Asimismo, Appia, el fundador de la iluminación moderna, es el primero en utilizar la sombra en el escenario de una manera absolutamente deliberada, como protagonista de la obra.

Tanto para Craig como para Appia, el teatro es un arte autónomo; la luz y el movimiento, orquestado por su director, forman esas imágenes que no pretenden enseñar, sino sugerir. Ambos escenógrafos transgreden los límites espaciales establecidos hasta el momento, proponiendo un teatro liberado del polígono rígido del escenario; un espacio neutro, insípido, ascético, sin la contaminación de las falsas perspectivas.

Los discípulos de estos escenógrafos son, entre otros, el ruso Vsévolod Meyerhold, que intenta oponerse a la imitación y transformar lo "no-dicho" en protagonista de su obra ${ }^{204}$, y el francés Antonin Artaud, fundador del teatro de la crueldad, que tanta polémica sigue suscitando en el mundo escénico.

Para Meyerhold, como también para Craig y Appia, el "movimiento escénico es más importante que cualquiera de los otros elementos teatrales porque es el que informa al espectador sobre sus pensamiento y sus impulsos". ${ }^{205}$ En su opinión, los gestos deben describir un dibujo preciso. Su obsesión por el cuerpo y su movimiento lo lleva a crear una técnica y una estética singular, a la que denomina biomecánica. Esta técnica no pretende reproducirse en un palco, sino desarrollar la plasticidad y la acrobacia corporal, proporcionando al alumno las herramientas fun-

\footnotetext{
201 Craig, El arte del teatro.

202 Craig, El arte del teatro, 105.

203 Craig, El arte del teatro, 105.

204 Vsévolod Meyerhold, "Sobre el teatro," en Teoría teatral (Madrid: Editorial Funda-

205 Meyerhold, "Sobre el teatro," 75.
} 
damentales para moverse de manera expresiva en el escenario y coordinarse de forma elegante y racional con sus compañeros.

(...) sirviéndose de un cierto procedimiento, toma el cuerpo de su compañero extendido en el suelo, lo echa en su espalda y lo transporta. Hace caer este cuerpo. Lanza un disco y tira un arco imaginario. Da una bofetada a su compañero y recibe otra (de la misma manera). Salta sobre el pecho de su compañero y lo recibe en el suyo. Salta sobre la espalda de su compañero, que se pone a correr llevándolo, etc. Algunos ejercicios eran simples: tomar la mano del compañero y tirar de su brazo, rechazar a su compañero, cogerlo por la garganta, etc. ${ }^{206}$

El teatro, hasta el momento burgués y literario, que confina al texto y a la declamación, es objeto de un giro radical, donde el cuerpo es estilización de su nuevo simbolismo. Para Meyerhold el teatro no puede ser naturalista y representar exactamente la realidad, ya que, siendo un arte, sus leyes se gobiernan de distinta manera.

El grado cero del teatro.

El silencio, la oscuridad, el vacío, la inmovilidad.

La sola presencia del CUERPO del actor impone la acción.

No se mueve, y sin embargo ya algo está sucediendo.

Es un milagro durante una décima de segundo.

La luz que recorre su CUERPO escribe la emoción imperante.

El aliento (neffesh) sobre la materia le otorga la vida.

Anima lo inanimado.

Si se mueve, la inquietud puede ser aterradora o dulce o terrible o hermosa.

Si emite un sonido, si sencillamente gime o grita o llora o tararea, la pieza ha comenzado. ${ }^{207}$

Para Seguí, "Meyerhold fue un importante teórico e innovador, estudia la oposición entre el teatro político y el teatro estético. Propuso lo grotesco. Intentaba provocar lo asombroso."208

Artaud va más lejos con su exploración teatral y rompe por completo con todas las tiranías y convenciones ideológicas vigentes.

Su búsqueda de "grado cero" radical, su irreverencia provocadora, su genialidad y sus ideas transgresoras despiertan el pánico y

\footnotetext{
206 Meyerhold, "Sobre el teatro," 75.

207 Marco Antonio de la Parra, "El cuerpo del actor. Teatro: teoría y práctica," Centro Latinoamericano de creación e Investigación Teatral2011, 3.

208 Javier Segui, "Aurora Herrera. Edward Gordon Craig: El espacio como espectáculo - Tesis Doctoral. (08-03-04)," 19 de marzo de 2015, http://www.javierseguidelariva.com/ Res/R\%20122.html.
} 
el temor en las mentes herméticas de la sociedad convencional, haciendo que Artaud ingrese en varias ocasiones en instituciones psiquiátricas. ${ }^{209}$

Lo que Artaud plantea es absolutamente innovador. Propone un mundo metafísico, transcendente y suprahumano, que fusiona el arte con la propia vida; un trabajo abierto, en constante proceso, porque las ideas acabadas son ideas muertas. Para él, el teatro realista y representativo ha llegado a su final, y en su lugar proclama el nacimiento de un teatro simbólico e intenso, al que llama "El teatro y la crueldad." Un teatro que pretende ser "un teatro serio que trastorne todos nuestros preconceptos (...) y actúe en nosotros como una terapéutica espiritual"210. Un rechazo de las zonas de confort de las sociedades burguesas, una renuncia a la dualidad como lógica de aquéllos para quienes el bien y la virtud forman parte de un código pre-convencional en el que "el impacto en el espectador, la realidad y lo real, es lo que devuelve al teatro su utilidad":211 Sobre ello, Jorge Dubatti dice: "La "crueldad" implica un giro epistemológico: regresar a la visión del misterio, de lo arcaico, del pensamiento salvaje, al reencantamiento del mundo, a una concepción de la vida "apasionada y convulsiva." 212

\footnotetext{
209 En 1925, Antonin Artaud escribe la mayor parte de los textos. Bajo el título general de «Carta a los poderes», se encuentra una misiva dirigida a los directores de manicomios: «Las leyes, las costumbres, les conceden el derecho de medir el espíritu. Esta jurisdicción soberana y terrible, ustedes la ejercen con su entendimiento. No nos hagan reír. La credulidad de los pueblos civilizados, de los especialistas, de los gobernantes, reviste a la psiquiatría de inexplicables luces sobrenaturales. La profesión que ustedes ejercen está juzgada de antemano. No pensamos discutir aquí el valor de esa ciencia, ni la dudosa realidad de las enfermedades mentales. Pero por cada cien pretendidas patogenias, donde se desencadena la confusión de la materia y del espíritu, por cada cien clasificaciones donde las más vagas son también las únicas utilizables, ¿cuántas nobles tentativas se han hecho para acercarse al mundo cerebral en el que viven todos aquéllos que ustedes han encerrado? ¿Cuántos de ustedes, por ejemplo, consideran que el sueño del demente precoz, o las imágenes que lo acosan, son algo más que una ensalada de palabras? No nos sorprende ver hasta qué punto ustedes están por debajo de una tarea para la que sólo hay muy pocos predestinados. Pero nos rebelamos contra el derecho concedido a ciertos hombres -incapacitados o no- de dar por terminadas sus investigaciones en el campo del espíritu con un veredicto de encarcelamiento perpetuo. ¡Y qué encarcelamiento! Se sabe -nunca se sabrá lo suficiente- que los asilos, lejos de ser "asilos", son cárceles horrendas donde los recluidos proveen mano de obra gratuita y cómoda, y donde la brutalidad es norma. Y ustedes toleran todo esto. El hospicio de alienados, bajo el amparo de la ciencia y de la justicia, es comparable a los cuarteles, a las cárceles, a los penales» En, Antonin Artaud, "Carta a los poderes," La cucaracha Ilustrada - Fondo Editorial, 3 de marzo de 2015, https://es.scribd.com/doc/119233499/ CARTA-A-LOS-PODERES.

210 Jorge Dubatti, "Antonin Artaud, El Actor hierofánico y el primer teatro de la crueldad," Revista Colombiana de las Artes Escénicas, enero-junio 2008, 74.

211 Dubatti, "Antonin Artaud, El actor hierofánico y el primer teatro de la crueldad", 77.

212 Dubatti, "Antonin Artaud, El actor hierofánico y el primer teatro de la crueldad", 77.
} 
Para el escenógrafo, el grave problema de la sociedad en general, reside en el hecho de que el ser humano occidental se entrega al materialismo y al racionalismo burgués, olvidándose de lo más importante: el espacio hierofánico (del griego hieros -sagrado). Y la función del arte no es más que recuperar ese misticismo vital. Para eso propone el "cuerpo del actor hierofánico" como medio operativo de ese lugar sagrado, para someter al espectador a un "tratamiento emocional de choque a fin de liberarlo del imperio del pensamiento discursivo y lógico para encontrar una vivencia inmediata en una nueva catarsis y una experiencia estética y ética original."213

Su creatividad y originalidad constituyen el detonante indiscutible de numerosas experiencias teatrales, como el happening ${ }^{214}$, la performance o la instalación. Diversos artistas recuperan estas novedosas experiencias, como la serbia Marina Abramović, "la abuela del arte de la performance", como ella misma se autodenomina. Abramović sigue su línea interpretativa absolutamente radical, ejemplo paradigmático del teatro insípido de grado cero. Con ella, se asiste al rejuvenecer de los nuevos lenguajes de las artes escénicas. Marina Abramović es toda una maestra en esgrimir la mirada resignada del público mediante un lenguaje absolutamente provocador y rebelde. Éste, igual que el de Artaud, rompe imaginarios y dualidades y despierta en el espectador sensaciones de extrañeza que lo obligan a salir de su entendimiento habitual.

\footnotetext{
213 Dubatti, "Antonin Artaud, El actor hierofánico y el primer teatro de la crueldad", 77.

214 El happening, el último ensayo del arte, conlleva en sí mismo el grado cero al desinhibirse de las convenciones haciendo una lectura, como dice Javier Seguí, absolutamente novedosa de su contexto. Happening: palabra que se deriva del verbo inglés to happen: «suceder», es, literalmente, lo que puede llegar a acontecer. Una definición propuesta en 1923 por el psicólogo Moreno insiste en su carácter de hic et nunc. El happening presenta un origen doble: el psicodrama con finalidad terapéutica y las manifestaciones publicitarias del movimiento americano Action painting. Es una forma dramática, en la medida que propone un espectáculo efímero parecido al teatro. Se ofrece en espectáculo una actuación dramática con acción, situación/conflicto y actores -que quizá hacen algo más que actuar, pues los personajes representados son, muy a menudo, su propio inconsciente-. Sin embargo, a diferencia del teatro, el carácter esencial del happening es la no-responsabilidad. Cada creación es única por ser improvisada. La libertad de expresión es total; no se requieren ni cuadro formal ni esquema estético. Se distinguen tres tipos de happening: 1) el controlado por un animador (actor), donde las situaciones representadas están establecidas de antemano; y las improvisaciones, previstas. Se estructura gira alrededor de texto en estado embrionario. 2) El que es una improvisación no estructurada y sin tema preestablecido, donde los únicos límites formales son el tiempo y el lugar, tiempos y lugares reales y no ficticios. 3) El happening «autónomo» que, al contrario de los anteriores, nunca se ofrece en espectáculo, sino que es el producto creativo e instintivo de la reunión de una veintena de personas que se «liberan». El happening como forma de expresión espontánea y psicoanalítica pretende ser un arte social. En: Étienne Souriau, «Happening,» en Diccionario Akal De Estética (Madrid: Ediciones Akal, 2010), 638.
} 
Sus trabajos destacan por la capacidad de crear una distancia entre el cuerpo y la mente, una distancia entre el "yo" y los "otros"; el constante abordaje de temas como el dolor, el tiempo, el aburrimiento o la vergüenza. ${ }^{215}$

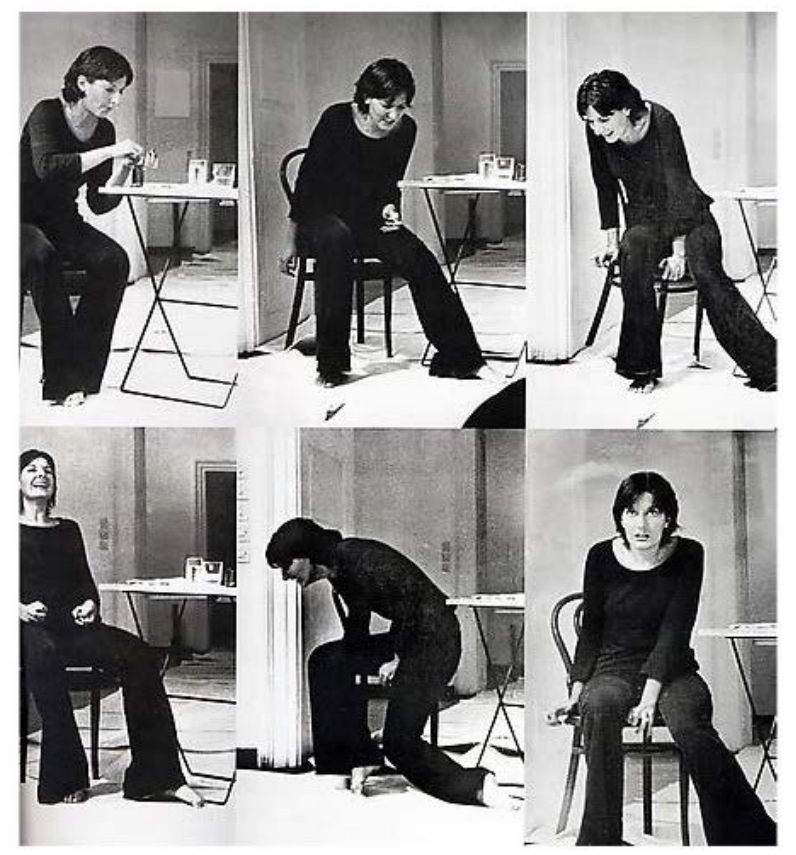

RITMO 2, (1974). Marina Abramović.

Sus performances se caracterizan por realizar experimentos que llevan su cuerpo al límite. Cabe destacar Ritmo 2 (1974), donde la artista toma ketamina ${ }^{216}$, provocando en su cuerpo una reacción dantesca y violenta, que acto seguido frena y convierte en efecto opuesto, al ingerir un calmante. En una de sus performances más provocativas, realizadas ese mismo año y a la que llama Ritmo 0, Marina Abramović pone a disposición del público asistente diversos objetos para que los utilicen con ella. Como describe la artista, a lo largo de las seis horas que dura la performance, las personas se vuelven progresivamente más violentas.

La experiencia que aprendí fue que... si se deja la decisión al público, te pueden matar... Me sentí realmente violada: me cortaron la ropa, me clavaron espinas de rosas en el estómago, una persona me apuntó con el arma en la cabeza y otra se la quitó. Se creó una atmósfera agresiva. Después de

\footnotetext{
${ }^{215}$ Gracia Iglesia Lodares, "Marina Abramovic, vida y muerte de la mujer-arte," ActivArte 2011.

216 La ketamina es una droga alucinógena con propiedades sedantes y analgésicas, pero conocida principalmente por sus cualidades anestésicas. Se utiliza en medicina, aunque su presencia es más habitual en la medicina veterinaria, por sus capacidades sedantes. De un tiempo a esta parte esta droga es de uso nocturno entre algunos jóvenes, provocando casos graves de sobredosis, e, incluso, de muerte.
} 
exactamente seis horas, como estaba planeado, me puse de pie y empecé a caminar hacia el público. Todo el mundo salió corriendo, escapando de una confrontación real. ${ }^{217}$

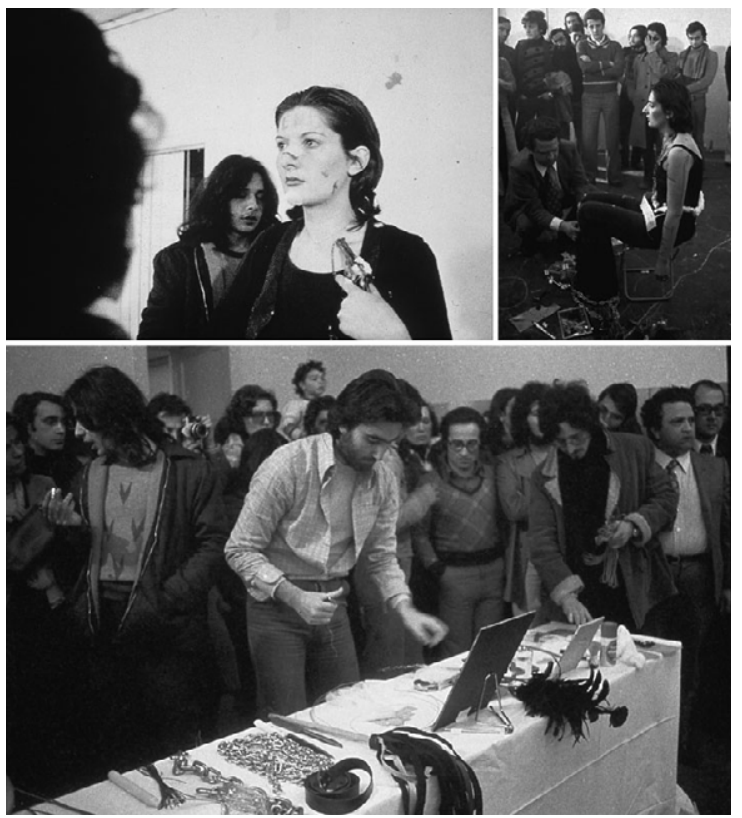

RITMO 0, (1974). Marina Abramović.

En su trayectoria abundan las performances provocativas en las que expone su cuerpo, llevándolo al límite. Todo es místico en la vida y la obra de la artista; en sus apariciones, se confunde el cuerpo con la mente; mezcla los límites hasta eliminarlos; no existen barreras entre ella y el público, entre su cuerpo y el de los otros, entre su mente y su cuerpo. Experimenta la vida en un misticismo celular donde todo se engloba y encaja; el suyo es el diálogo de la intensidad; y su deseo, ponerse a prueba a sí misma y al público que la mira. Cuerpo, mente y público se entremezclan hasta eliminar sus límites, transformando la representación en un happening de inolvidable extrañeza; un diálogo de intensidad basado en impulsos corporales.

Acerca de sus intervenciones artísticas, Javier Seguí establece una estrecha comparación de su estilo innovador y provocativo que "en mil novecientos ochenta y tantos, Isidoro Valcárcel Medina hacía una obra que se llamaba La visita. Lo contratabas y un día te batía a la puerta y te decía: vengo hacer la visita. Se sentaba y no hacía nada."218

Todos los artistas inquietos buscan esa liberación de las amarras ideológicas clásicas, rechazando los lugares comunes y llevan- 
do a cabo "un intento radical de llegar a un grado cero del teatro. Una búsqueda después de la aniquilación de las preceptivas (...) una inmersión en la palabra poética y en el silencio, (...) una atrevida y personal inmersión en eso que Lorca llamó 'teatro bajo la arena'."219

Esta línea de radicalidad la marca también el filósofo francés Jacques Rancière, que plantea un "teatro sin guión", con guión indefinido, hecho a partir de las reacciones variadas e imprevisibles del público, principal responsable del desarrollo de la acción.

En su libro El espectador emancipado ${ }^{220}$, Rancière deja al descubierto las lagunas del teatro burgués tradicional y su mala costumbre de indicar al espectador cómo debe ver, sentir y comprender, sin darle la libertad de "traducir a su manera aquello que él o ella percibe, de ligarlo a la aventura intelectual singular que los vuelve semejantes a cualquier otro aun cuando esa aventura no se parece a ninguna otra."221

Para Rancière "emancipar" significa abolir las fronteras entre actor y espectador; crear hábilmente lugares donde el espectador se implique en la acción, como lo hace Artaud con su teatro de la crueldad, o el poeta alemán Bertolt Brecht, que propone la reflexión del espectador desde fuera, para no implicarlo y condicionar su manera de sentir la obra.

En el teatro hay una obra muy importante de Rancière, titula-
da El espectador emancipado, que tiene que ver exactamen-
te con ese nuevo teatro de la acción, de compartir. Quiero
decir, tú estás haciendo una obra y resulta que involucras al
público, entonces en ese instante empieza otra cosa. No tie-
nes ni guion. Tienes que producir la obra en la medida que se
va produciendo el incidente. Es una cosa muy emocionante,
¿no? El happening es importantísimo, claro. ${ }^{222}$

Ambos desean arrancar al espectador de su inercia, estancada en la imagen segregada por la representación; que el público busque sus propios instrumentos de entendimiento, que abandone la cómoda pasividad de mero observador para tornarse crítico frente a lo que ve y, en realidad, frente a sí mismo. Para Rancière, ese es el verdadero objetivo del teatro: des-movilizar el pensamiento del espectador.

\footnotetext{
219 José Luis Campal Fernández, "Ernesto Caballero. Obra a obra.," La ratonera, enero 2007, 76 .

220 Rancière, El espectador emancipado.

221 Rancière, El espectador emancipado, 23.

222 Seguí, 8 de abril, 2014.
} 
Su libro, eminentemente político, contempla al espectador no sólo en el mundo del teatro, sino en la vida. La apatía de uno es el reflejo del otro. Y el arte tiene el deber de derribar esas barreras, en lugar de pretender construir modelos o representaciones que resultan obsoletos en el mismo instante en que nacen. Un arte que sea capaz de salir de sí mismo y, como plantea Malévich en su época, "ya no hacer cuadros, sino construir directamente las formas de la vida nueva."

También la activista, escritora y crítica de arte estadounidense Susan Sontag, coetánea de Rancière, es una referencia habitual de Javier Seguí por sus conceptos radicales sobre el arte. Para la artista, si al principio el arte trata de ser una herramienta capaz de alcanzar la conciencia humana, ahora se reivindica el arte como herramienta para auto-alienarse del mundo. Pero para Sontag el arte es, sobre todo, la búsqueda del "silencio"; más allá del discurso, el arte debe acercarse al antiarte, a la eliminación del 'tema' (del objeto, de la imagen), a la sustitución por el azar y la búsqueda del silencio."223

Con esta nueva percepción, aflora un problema mayor en la nueva manera de observar el arte: si es invariablemente materia, la desmaterialización del arte es una barrera que no puede transcenderse. Esa paradoja provoca tamaño rechazo en algunos artistas que son varios los que, como Oteiza, abandonan su recorrido.

Rimbaud partió para la Abisinia para hacer fortuna en el comercio de esclavos.

Wittgenstein, después de un período como maestro-escuela del pueblo, eligió un trabajo servil como empleado de un hospital. Duchamp dio un giro hacia el ajedrez. Como acompañamiento de esas renuncias ejemplares a una vocación, cada uno de ellos declaró que veía sus realizaciones previas en la poesía, en la filosofía, en el arte, como fútiles e insignificantes. ${ }^{224}$

Para estos artistas, el arte sólo recobra su significado con su abandono. Un abandono que, como dice Sontag, es "el último gesto extraterreno del artista." 225 No un abandono como el silencio edificado por Cage con intención discursiva, un abandono donde esas formas que parecen no tener ninguna repercusión emocional generan con-mociones inesperadas.

Actualmente, el silencio surge como manifiesto para decir algo 
cuando no se tiene nada que decir. Es como si la historia condenara la originalidad de todo lo que queda por hacer. Como dice Oteiza, ya no hay nada más que inventar. El arte ha muerto. Tal vez el silencio pueda constituir esa huida de la historia. Un arte que no se mira, que se cuelga. Un arte que anula al sujeto, que anula el autor, que anula la mirada, que se anula a sí mismo, que anula el lenguaje contaminado por la avalancha de la información digital. Re-definir palabras. Re-definir el imaginario. La negación que Schönberg anuncia cuando prohibe la jerarquía preferencial de algunas partes. ${ }^{226}$ Hay que dejar en blanco el pensamiento. Salir de la zona de confort que condiciona la acción por exceso de seguridad.

El arte desea ser transparente, no tener estilo, huir de la interpretación, porque ésta reduce el mundo, lo domestica. El arte sólo es el modo de nombrar las emociones, y el estilo del que se sirve el artista para hacerlo no es más que el idioma en que despliega sus formas.

Foucault habla del grado cero de las figuras retóricas. Esto se produce cuando se habla sin planteamientos previos. Tiene que ver con esa cosa que se llama la parresia. El hablar verdadero. Tú hablas sin pensar lo que vas a decir. Vas articulando la frase, el decir en la medida en que lo vas diciendo. A eso Foucault le dedica muchísimo estudio, y eso enlaza también con las cosas de Hannah Arendt y de Nietzsche del: "primero hablas y luego piensas. ${ }^{227}$

Seguí menciona una experiencia de grado cero en los sucesos del 11-M. Se trata de un acontecimiento extremo que hiela la imaginación y revela el mundo putrefacto de la "ciénaga" del literato Giorgio Manganelli:

La ciénaga se despliega como nacida de un axioma coprológico, y la contemplo sin miedo, sin veneración, sin esperanza, como algo que me es semejante, puesto que si un dios esfínter la ha generado, yo mismo ¿no habré sido generado de igual manera, no acabaré por ser devuelto a mi naturaleza de excremento, pero excremento del esfínter divino, salido de la nada? $?^{228}$

Ante estos hechos desconcertantes, que forman parte de esta "vida repelente e inagotable", donde "todo repta, silba, atormenta, muere, copula, nace, defeca"229, se cuestiona el sentido la

226 Sontag, A Vontade Radical: Estilos, 14.

227 Seguí, 20 de mayo, 2014.

228 Giorgio Manganelli, La ciénaga definitiva, trad. Carlos Gumpert (Madrid: Siruela, 2002), 44

229 Manganelli, La ciénaga definitiva, 35. 
vida, y sólo en el Apocalipsis se encuentra la respuesta aquellos que hacen de este "espacio admirable y horrendo un cementerio y un nido". 230

Otro acontecimiento similiar al 11-M que menciona Javier Segui es el 11-S, fecha en que las icónicas torres neoyorquinas se derrumban a raíz de un ataque terrorista y que, a semejanza del Titanic, representan "el símbolo del poder de la civilización industrial del siglo XX". ${ }^{231}$. También en este caso sucede lo inimaginable, lo incomprensible, lo insólito, que saca a la sociedad de su ambiente artificial de confort con su entendimiento de la vida.

Estados Unidos, la supuesta potencia mundial altamente controlada por un riguroso sistema de vigilancia inteligente, inmune a todo acto terrorista, se viene abajo de manera inesperada. Este acontecimiento traumático, también de grado cero, asombra y bloquea la razón. Sucesos de esta magnitud hacen cambiar por completo la percepción de la realidad y cuestionar los límites de las libertades, de la democracia.

Son estos hechos los que activan el "grado cero de conciencia social" y obligan a adjudicar al individuo el papel que encarnó, a medos del siglo XIX, Giuseppe Garibaldi durante la independencia de los territorios americanos con posterioridad a la guerra napoleónica que, tal como cuenta Seguí "se ofrece hasta al presidente de los Estados Unidos para hacer una revolución. ¡Un personaje que se ofrece para hacer revoluciones! Es una cosa impresionante."232

El grado cero representa la esencia de esa revolución contra la entropía y la inercia a que las sociedades están sometidas. El grado cero es desmantelar la realidad esclavizada por lo factible, rendida a la fuerza de la imagen.

Pero el grado cero es un estilo, perteneciente a una concepción estilística distinta; como todas las demás. Susan Sontag apunta a la referencia inicial del grado cero.

Lo que Roland Barthes denomina "grado cero de la escritura" resulta, precisamente por antimetafórico y deshumanizado, tan elaborado y artificial como cualquier estilo tradicional de escritura. No obstante, la noción de un arte transparente, sin estilo, es una de las más tenaces fantasías de la cultura moderna. Críticos y artistas pretenden creer que es más difícil privar el arte del artificio que, para una persona, perder la

230 Manganelli, La ciénaga definitiva, 19.

231 Slavoj Zizek, “¡Bienvenidos al desierto del real!,” El amante, octubre 2001, 27.

232 Seguí, 8 de abril, 2014. 
personalidad. Aun así, la aspiración resiste, como una permanente disidencia del arte moderno, con su vorágine de cambios de estilo. ${ }^{233}$

El cero no es una negación, un final o un punto sin retorno, sino una destrucción necesaria para un nuevo comienzo. Es preciso destruir para poder crear, ${ }^{234}$ destruir las convenciones clásicas y empezar prescindiendo de las convenciones del pasado.

Gracias a la conciencia espacial, la pintura se ha desarrollado hacia la creación constructiva. Para encontrar un sistema adecuado a las ordenaciones espaciales es necesario eliminar todos los sistemas superados del pasado, con todas sus implicaciones a través de un progreso ininterrumpido por el nuevo camino. (...)El triunfo del presente sobre las costumbres del pasado, la purificación de la conciencia... (...) Todo lo que aún pertenece al pasado es ecléctico: la carretera, el arado primitivo, el caballo, el trabajo doméstico, la pintura de paisajes, las estatuas de la libertad, los arcos del triunfo $y$, sobre todo, la arquitectura, al estilo antiguo. Todo resulta ecléctico mirado desde la época del avión y de la radio. ${ }^{235}$

Es curioso observar que, en la evolución de las personas, este proceso depurativo suele producirse en una época tardía, como en Javier Seguí, después de haber efectuado un largo recorrido. Como dice Bachelard, para escribir poesía tiene que haberse vivido tanto como para empezar a soñar. ${ }^{236}$ Javier añade que "no puedes escribir si no has escrito antes. Y cuanto más has escrito, más facilidad tienes de colocarte en el grado cero."237 El grado cero no es "falta" o "ausencia" de conocimiento, sino un proceso de gran exigencia cognitiva. Una especie de "inocencia del hacer transformada en perspicacia total". ${ }^{238}$ Una inocencia que sólo se puede recuperar quitando cosas de en medio después de haber hecho mucho. Una ascesis que se procesa en el origen, y donde la experiencia es tan sólo una referencia de lo que no hay que volver a repetir ${ }^{239}$ pero, "si nos remontábamos a cero no era, desde luego, con el objetivo de permanecer en él, sino solamente de volver a tomar pie."240

\footnotetext{
233 Susan Sontag, "Sobre el estilo," en Contra la interpretación (Buenos Aires: Aguilar, Altea, Taurus, Alfaguara, 2005), 42.

234 Hernández-Navarro, "El cero de las formas. El cuadro negro y la reducción de lo visible," 127-128.

235 Payet, Montaner, and Oliveras, Textos de arquitectura de la Modernidad, 220.

236 Gastón Bachelard, El aire y los sueños - Ensayo sobre la imaginación del movimien-

to, trad. Ernestina de Champorcine (México: Fondo de Cultura Economica, 1993).

237 Seguí, 28 de octubre, 2014

238 Seguí, 28 de octubre, 2014

239 Seguí, 28 de octubre, 2014.

240 José Aponte Carrasco et al., "Dibujar ¿para qué? Notas para el debate sobre el papel de la formación gráfica en la carrera de arquitectura," Ega XII Congreso Interna-
} 
Muchos artistas dan este giro absolutamente radical cuando, Ilegados a un estadio avanzado de exploración y dominio de sus técnicas, se percatan de que hay que volver a empezar olvidando todo lo aprendido. Ese momento suele llegar mediante un ejercicio de introspección provocado por experiencias esotéricas o por la proximidad a la muerte.

En el caso de Javier Seguí, el grado cero proviene de una fase de extrañeza respecto al camino recorrido hasta entonces, que lo lleva a cambiar radicalmente su manera de dibujar y escribir.

Seguí, al igual que Oteiza: "cuando era joven ponía cosas, muchas cosas en la escultura, y cuando se va haciendo mayor va empezando a quitar cosas". ${ }^{241}$ Inesperadamente en las últimas dos décadas de su vida también Joan Miró ${ }^{242}$ sigue esta línea depurativa y protagoniza un giro radical, convirtiéndose en un interesante paradigma para este estudio.

Asociado sobre todo a un estilo representativo, Miró efectúa en el último período de su vida un interesante desplazamiento hacia un barrido de la representación anterior. ${ }^{243}$ Es indudable que el

cional de Expresión Gráfica Arquitectónica (2008): 61.

241 Seguí, 28 de octubre, 2014

242 Joan Miró, sometido a presiones paternas, inicia su vida profesional como comerciante. Más tarde acaba ingresando en la famosa Academia de Artes, donde toma el primer contacto con las tendencias europeas en el mundo del arte. Conoce a Picasso y a algunos miembros de la corriente dadaísta y firma el Manifiesto en 1924, ratificando su afinidad al surrealismo y su gusto personal por la obra de Paul Klee. Se casa, y dos años más tarde, nace su única hija. En esta época empiezan sus conflictos personales con el verdadero significado de la pintura. Con el estallido de la Guerra Civil Española, Miró huye a París, pero la inminencia de la Segunda Guerra Mundial obliga al artista y a su familia a regresar a España. Al volver, Miró abandona el surrealismo, del que es un reconocido vanguardista, y tiene la oportunidad de reunir, revisar y redefinir la totalidad de su obra. Su relectura le proporciona una reflexión detenida, y en este proceso de introspección, el artista descubre la manera de simplificarla y sistematizarla rompiendo con la «jerarquización de los signos artísticos y la absoluta libertad expresiva, en dos y en tres dimensiones» en Carmen Fernández Aparicio, "Miró último (1963-1983): La experiencia de mirar," ed. Museo Nacional Centro de Arte Reina Sofía (Sala Valentín Palencia de la Catedral de Burgos Fundación Silos, 2014). El anhelado retorno a su país le devuelve serenidad, y su nueva forma de reflexionar afecta a su vida y su obra. Después de un largo recorrido experimentando y probando trazos y formas, Miró termina haciendo un «vaciado», un despojamiento de toda su obra, con el objetivo de alcanzar el grado cero de la pintura.

243 En enero de 2014, la Sala Valentín de la Catedral de Burgos acoge una exposición titulada «Miró último (1963-1983): La experiencia de mirar», promovida por el Museo Nacional Centro de Arte Reina Sofía y la Fundación Silos. En ella se exhibe un total de treinta obras del autor, de las décadas de los años sesenta y setenta, período en que su contexto personal e histórico ocasiona un cambio fundamental en su trayectoria. Como comenta Manuel Borja-Villel, director del Museo Reina Sofía, durante este período Miró «llevaba la pintura a un "grado cero", al mismo tiempo que observaba con atención el asalto a la esfera pública y los sucesos históricos que tenían lugar durante aquellas 
pintor, en este período, desea alcanzar el grado cero en su pintura a través del despojamiento y del vacío. Su larga vida ortodoxa -resultado de las expectativas sociales, familiares y cristianas- lo lleva a un desgaste emocional y a la inevitable necesidad de liberarse de las ataduras que lo constriñen toda su vida. Por este motivo, las obras de este período representan una significativa y desesperada liberación de todos los vínculos mantenidos a lo largo de setenta años. Con la proximidad de la muerte, se produce un madurar absoluto en toda su obra y su credo. En 1918 Miró escribe a su amigo Enric Ricart:

\section{Nada de simplificaciones o abstracciones; en estos momen- tos me interesa solamente la caligrafía de un árbol o de un tejado, hoja a hoja, rama a rama, hierba a hierba, teja a teja. Eso no quiere decir que al final los paisajes no puedan ser cubistas o sintéticamente salvajes. Ya lo veremos. ${ }^{244}$}

SIn embargo, medio siglo después esa representación cede el protagonismo a la metáfora dialogante diciendo que "para mí es importante conseguir la máxima intensidad con el mínimo esfuerzo. Por eso el vacío ocupa un papel cada vez más relevante en mis cuadros." 245

Esta aparente contradicción en sus afirmaciones es la prueba de que el tiempo hace que la relación del artista con el arte acompañe el madurar del pensamiento y del cuerpo. En el recorrido artístico de Miró, se palpa cómo sus últimas obras llegan "a los límites máximos de depuración de pintura, organizando espacios poéticos donde la vibración, el ritmo y la emoción son protagonistas". ${ }^{246} \mathrm{El}$ artista hace uso de un "espacio pictórico desprovisto de narración, desnudo de expresión, como metáforas de la naturaleza de la práctica artística: la nada, el grado cero, como vehículo de transformación". 247 "Inocencia del hacer transformada en perspicacia total." ${ }^{48}$

Su proceso catártico se ve influido no sólo por la poesía y por la escritura, sino también por su viaje a Japón y la toma de conciencia de la técnica de la caligrafía oriental. Según escribe Jacques Dupin, su ya fallecido biógrafo francés, "lo que impulsa a Miró a grabar y a litografiar con tanta fuerza y energía es la poesía, y el deseo de unir la poesía de su pintura a la escritura 
de los poetas." 249

¿Qué es lo que detiene la trayectoria que se dibuja a lo largo de toda la vida y cuáles son los factores que provocan esa especie de catarsis y abandono de las creencias anteriores? ¿Factores económicos, estéticos, ideológicos o simplemente la necesidad de huir de una vida llena de con-tradiciones? ¿La necesidad de limpiar los adornos de una vida dogmática que siembra el imaginario de incertidumbre? ¿Una felicidad aparente enmascarada por continuas contradicciones?

Es oportuno constatar la relación de estos autores con la mística y las religiones ocultas. Sobre esta tendencia, Seguí reflexiona:

En el siglo XIX y en el XX empiezan a aparecer en toda Europa unas cosas rarísimas que son esas sociedades secretas, esotéricas, mágicas. Todos los artistas se conectan con esta gente. Es una cosa alucinante. Está todo el mundo metido en esos ajos hasta los ojos. Esto tiene que ver con la conciencia mística, con las meditaciones orientales que al llegar a Occidente se mezcla con toda esa historia... ${ }^{250}$

Hay una cantidad enorme de experiencia imaginaria que no va a ninguna parte porque no se retiene. Eso es esoterismo, no sé lo que es. Deleuze, Blanchot. Todos hablan de lo mismo. Pero resulta que la física también está encontrando esas cosas. A finales del XIX, principios del XX, aparecen el principio de la indeterminación de Heisenberg, la termodinámica, los campos de fuerza de Maxwell, la teoría de la Gestalt, todo tiene que ver con eso. La relatividad, las geometrías euclídeas son todas de la misma época. Coinciden exactamente con la aparición en todo el universo de esas nuevas religiones. ${ }^{251}$

La obra de Miró, por ejemplo, se revela en su vivencia mística, religiosa y bíblica y su identificación con la cultura japonesa y la creencia en la reencarnación. ${ }^{252}$ La eliminación de los residuos representativos acumulados a lo largo de su vida surge, sobre todo, como necesidad de desmantelar una vida llena de contradicciones. ${ }^{253}$

\footnotetext{
249 Efe, "La plástica de Miró desde las palabras de Dupin," El mundo multimedia,2008, 10 de diciembre de 2014: http://www.elmundo.es/elmundo/2009/06/16/barcelona/1245166969.html. EFE. «La plástica de Miró desde las palabras de Dupin» El mundo Multimedia (junio 16, 2008), 10 de diciembre de 2014, http://www.elmundo.es/elmundo/2009/06/16/barcelona/1245166969.html

250 Javier Seguí, entrevistado por Maria Brito, 10 de diciembre, 2013, Grabación.

251 Seguí, 10 de diciembre, 2013,

252 Saturino Pesquero, Joan Miró: La intencionalidad oculta de su vida y obra. (Barcelona: Erasmus Editores, 2009), 17-30.

253 Algunas contradicciones son perceptibles en su recorrido. Por un lado, critica a los artistas que desean alienarse de la realidad. Para él «es de suma importancia no provo-
} 
Para entender su proceso depurativo es también inevitable mencionar la tradición catalana-semita-cabalística. La alquimia, el infinito, la inmortalidad, la unificación de lo celestial y de lo terrenal son detalles importantes para entender un Miró que alimenta su imaginario con aspectos relacionados con la numerología y la astrología, entre otras prácticas religiosas y místicas. El detonante de su depuración también puede tener que ver con su particular creencia de lo que Carl Jung llama fenómenos sincrónicos, que definen las circunstancias que derriban las barreras del espacio y del tiempo.

Para Malévich, por ejemplo, su abstracción más radical resulta de la búsqueda de la esencia, vinculada a la Sociedad Teosófica; mientras que para Cage, profundo conocedor de la filosofía zen, la búsqueda de la "iluminación interior" se encuentra en la afinidad con la realidad, y no en el aislamiento personal. Esta constatación hace que el músico busque los sonidos fuera de su cabeza, hallando en los ruidos de la ciudad sus nuevos instrumentos musicales:

\begin{abstract}
Dondequiera que estemos, lo que oímos es ruido. Cuando lo ignoramos, nos incomoda. Cuando lo escuchamos, descubrimos que es fascinante. El sonido de un camión a noventa kilómetros por hora. La lluvia. Nosotros queremos capturar estos sonidos, utilizarlos, no como efectos sonoros, sino como instrumentos musicales. ${ }^{254}$
\end{abstract}

La Sociedad Teosófica surge a finales del siglo XIX como oposición al dogmatismo materialista de la época. Se trata de un colectivo universal, sin distinciones religiosas o sociales, que intenta demostrar la existencia de fuerzas ocultas todavía desconocidas por la ciencia. Su base son las filosofías esotéricas orientales y busca lo que llamaran la "Divina Sabiduría", como su propio nombre, de origen griego, indica: theos (dios) y sophos (sabio). Esta nueva religión filosófica es, sobre todo, una

\footnotetext{
carla con medios químicos, ya sea con bebida o droga». Así que su vehículo «sin pecado» para alienarse de la realidad lo consigue absteniéndose de comer. También critica la deplorable producción artística por cuestiones simplemente económicas, llegando a escribir que «los franceses (y Picasso con ellos) son los condenados, ya que han tomado el camino fácil y pintan para vender». Pero, al cumplir cincuenta y dos años y darse cuenta de que no ha obtenido beneficios económicos de su pintura, asume su aspiración a llegar a un público más masivo, no vivir modestamente y «Seguir llevando la vida mediocre de un modesto caballero». Por un lado, respeta las normas del compromiso y la unión eterna de un matrimonio fiel y cómplice, pero, por otro, le agobia la sombra de su mujer. En un momento determinado, Miró se plantea salir de Mallorca, porque no quiere ser tan sólo «el marido de Pilar», oriunda de la isla.

254 Javier Ariza, "John Cage: Aperturas musicales," en Las imágenes del sonido: Una lectura plurisensorial en el arte (Cuenca: Ediciones de la Universidad de Castilla-La Mancha, 2003), 42.
} 
doctrina esotérica de contenido masónico en la que un colectivo de sabios expresa en sus abstracciones sus ideales espirituales: "El sabio saborea el desabor y se ocupa de la desocupación. El sabio está en la espaciación, en el vaciado, en el nacimiento de lo arquitectónico. En el lugar de más potencialidad. En el hecho borrado."255

Al igual que Malévich, también Kandinsky y Mondrian son seguidores de esta ideología. Para los padres de la abstracción, el arte es la revelación del enigma divino, que sólo se puede transmitir a través de la abstracción. Como lo hace El Greco en su momento, estos artistas desean que su obra revele lo invisible; primero con una representación simbólica, hasta llegar a la reducción de la abstracción. A este creciente interés por el mundo místico y espiritual se suman nombres como el coreógrafo norteamericano Merce Cunningham, que propone en estos agitados comienzos de siglo una danza sin gestos como grado cero del lenguaje corporal. A ellos se une, asimismo, el artista alemán Joseph Beuys, para quien la intuición es la forma más elevada de la razón. También este artista propone un alejamiento de la trayectoria habitual y de las instituciones obsoletas.

Javier Seguí, que también vive en su juventud todas estas experiencias esotéricas, confiesa: "siempre me ha resultado muy atractivo el tema de lo esotérico y el tema del misticismo."256

\begin{abstract}
Yo lo viví porque era un componente de mi juventud, absolutamente universal, estaba por todas partes. Es lo mágico, lo más primitivo, lo que está pegado a la infancia. No es la infancia, pero es lo que está después. El fundamento mágico y analógico. Luego, a lo largo del tiempo, descubrí que es una técnica imaginaria de primera magnitud. La más importante de todas. El esoterismo, pensar que hay cosas ocultas, o que las cosas tienen una significación universal, cósmica. Que lo que está arriba es igual que lo de abajo, que lo pequeño es igual que lo grande. Esos fundamentos, que están en todas las magias, me parece que son una clave imaginaria tan potente que me horroriza que no se estudie como tal. Que no se divulgue, que no lo sepa más gente. ${ }^{257}$
\end{abstract}

Seguí comenta que, en 1968, traba amistad con una astróloga para estudiar astrología, gnosticismo, magia, numerología y gematría, todos los cuales beben del judaísmo esotérico ${ }^{258}$.

Añade que cuando termina la carrera le faltan fundamentos, no

255 Seguí, Dibujar, proyectar (IX) - El grado cero de la arquitectura, 41.

256 Seguí, 18 de febrero, 2014

257 Seguí, 4 de marzo, 2014

258 Ocultista, masón, mago, y escritor británico. 
sólo psicológicos y filosóficos, sino también mágicos. Por ese motivo confiesa que empieza por la astrología y temas de adivinación, hasta derivaciones en sectas "extrañas". ${ }^{259}$

Inmerso en temas metafísicos, Javier Seguí llega, incluso, a dibujar sus propias cartas de Tarot con un estilo geométrico ${ }^{260}$. También admite que en los años setenta, antes de obtener la cátedra, estudia incluso astrología con una bruja de Madrid, y en 1973 asiste a una convención de brujos en Ibiza en la que está destinado a ser el brujo más importante de la reunión. Las situaciones esotéricas que Javier Seguí vive constituyen, sin lugar a dudas, un importante legado en su recorrido. Según dice, en esa misma convención algunas personas llegaron a abordarlo diciéndole que su destino era ser maestro de magias.
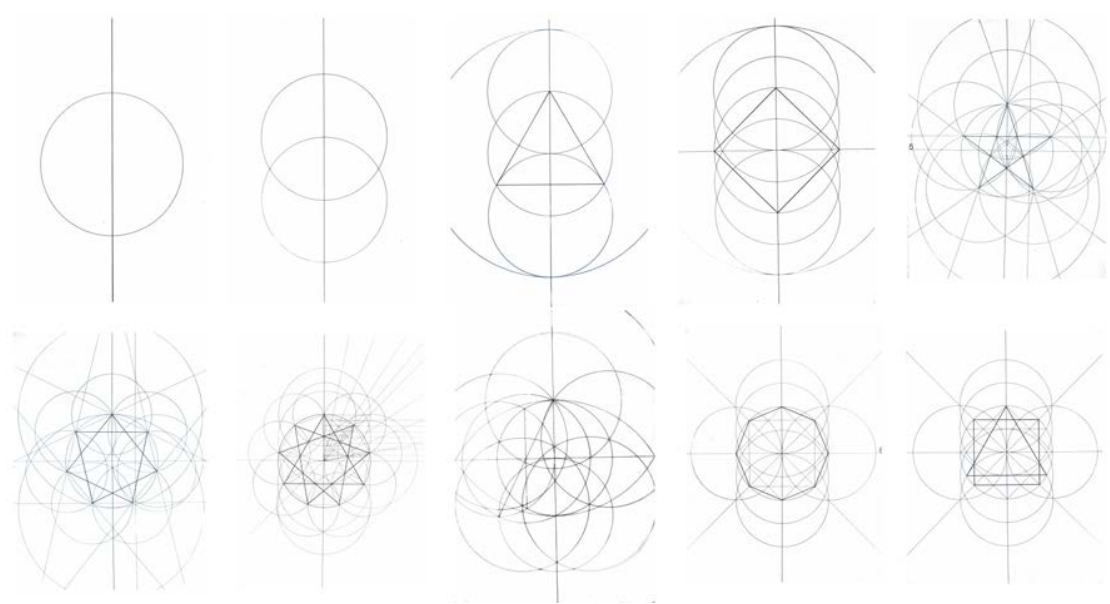

CARTAS DE TAROT GEOMÉTRICO, (1979). Javier Seguí. Dibujos de los polígonos y poliedros regulares correspondientes a las diez primeras figuras, partiendo de operaciones con principios geométricos y cuyo significado simbólico coincide con los arquetipos de los diez primeros arcanos del Tarot. Según el propio Javier Seguí, sus cartas de Tarot no están hechas a partir del símbolo de las cosas, sino a partir de las operaciones para utilizar la figura.

\footnotetext{
259 Seguí, 18 de febrero, 2014

260 «La capacidad sugestiva, evocativa y explicativa de los polígonos y poliedros regulares es conocida desde la antigüedad. La tradición esotérica se funda en la idea mágica de que las cosas son, al mismo tiempo, la realidad que son, el sonido que emanan, la figura que las contiene y las puede representar y el número que sintetiza su figura. De tal suerte que entre todas las cosas existe un nexo oculto, comprensible sólo para algunos, que las hace partícipes unas de otras de manera operativa y práctica. La misma tradición, en este sentido, clasifica las figuras más simples, las convierte en símbolos de los principios eternos y de las cosas y las relaciona ordinalmente como producciones a partir de los principios básicos. Estos principios son: el punto, el círculo y la recta. Siendo los humanos sensibles a la evocación de las figuras regulares, y habiendo experimentado la capacidad comprensiva que convocan en situaciones especiales (como en la interpretación astrológica, en talismánica, en adivinación, en la ideación artística, etc.)» En Javier Segui, "Experiencias Graficas - Arte y conocimiento," Fundación Universidad (1979): 5.
} 
Estos relatos, aparentemente inocentes, forman parte de una importante parcela del aparato cognitivo de Javier Seguí, determinan su sensibilidad mística e influyen en su percepción del mundo, tanto exterior como interior.

\begin{abstract}
Yo siempre supe que lo esotérico era arquitectónico, y que lo arquitectónico era esotérico. Arquitectónico quiere decir eso. (...) Mi Tarot geométrico y mi entrada exactamente en el mundo esotérico. Hice un Tarot geométrico y tuvo un éxito bárbaro. 261
\end{abstract}

A partir de estos fundamentos, decide extender las figuras a números superiores de la decena, tomando en consideración trazados de formas pictóricas y arquitectónicas a lo largo de la Historia; el árbol sefirótico o el estudio del Tarot de Oswald Wirth, entre otros. Esta visión permite la construcción de un esquema donde se generan los veintidós arcanos mayores, cuyo resultado final es un manual para el estudio significativo de las formas mandálicas para reflexionar y meditar.

Como se ha mencionado, la lectura del libro del Zohar, un libro esotérico judío, deja una huella indeleble en el recorrido de Javier Seguí, quien lo considera una "lectura alucinante", ${ }^{262}$ "un libro profético-místico, incomprensible desde la racionalidad. Su fuerza poética (metafórica) es altamente perturbadora."263

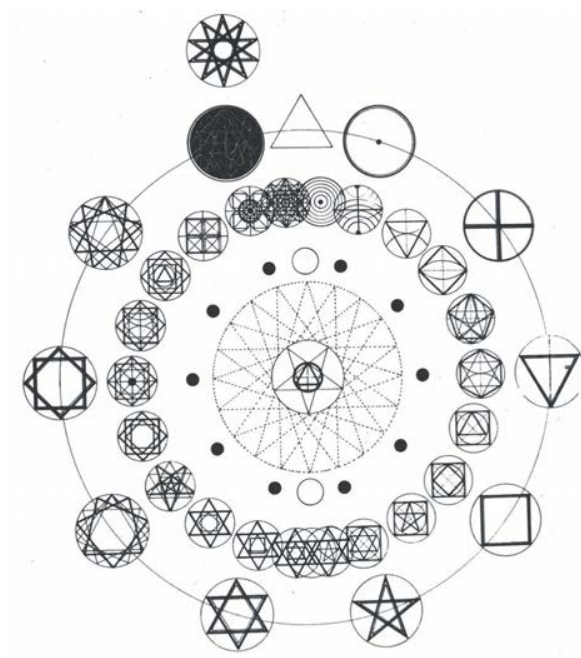

FIGURAS GEOMÉTRICAS CORRESPONDIENTES A LOS VEINTIDÓS ARCANOS MAYORES DE LAS CARTAS DE TAROT GEOMETRICO, (1979). Javier Seguí. Esquema. 
En este contacto místico se busca un conocimiento individual que permite un mayor desarrollo creativo.

Algunos dicen que la imaginación es el fundamento vital, estar vivo es tener una energía que de alguna manera te soporta, y te fabrica cosas, te hace proyectar en el mundo, en algo exterior a ti, algo que pasa en tu interior. Bueno, el asunto es que en algunas escuelas esotéricas que ha habido, todas se basaban más o menos en lo mismo, el budismo y todo eso. ${ }^{264}$

En el trascurso de estas indagaciones, Javier Seguí hace referencia a un nombre de suma importancia en este ámbito y que aporta nueva información.

Hay un tío esotérico importante que se llama Rudolf Steiner, que es el inventor de una cosa que le llamaba la antroposofía, que es la transformación de otra cosa que se llamaba la teosofía, que es otra cosa que viene exactamente de la gnosis mística. Hay dos teorías: la materia genera pensamiento, genera energía o genera la vida; la otra es que la vida está antes de la materia. De cualquier modo, la experiencia que tenemos es que vida y materia coinciden en el ser humano. ${ }^{265}$

Rudolf Steiner, el erudito y polémico literato fundador de la antroposofía, diseña diecisiete edificios durante su vida, algunos de ellos considerados muy relevantes en la arquitectura moderna: el Goetheanum I y el Goetheanum II. ${ }^{266}$ Su antroposofía, resultado de una evolución de la teosofía, pretende conquistar un espacio entre lo artístico y lo místico, y sus edificios son dibujados rigurosamente siguiendo una geometría sagrada.

También Oteiza, que muestra una clara afinidad con la metafísica heideggeriana, se aproxima al budismo zen y a la tradi-

\footnotetext{
264 Javier Seguí, entrevistado por Maria Brito, 17 de diciembre, 2013, Grabación.

265 Seguí, 17 de diciembre, 2013.

266 "Su antroposofía es el resultado de su incursión en la teoría del mundo de Goethe. Por este motivo, el edificio que se llamara anteriormente Johannesbau, recibe el nombre de Goetheanum. A semejanza del proyecto de geometría sagrada aplicada en la Sagrada Familia de Gaudí, este templo representa el resultado de una evolución espiritual y simbólica en la arquitectura. Al igual que los templos paganos antiguos, el Goetheanum tiene una orientación este-oeste y su acceso se sitúa por el lado oriental. El triángulo pitagórico representa la fusión entre lo masculino y lo femenino, y la estructura cerebral. En su ideología, el edificio es el intermediario entre tierra y cielo. Steiner introduce una nueva terminología en arquitectura llamada «euritmia», palabra de origen griego que significa «belleza o armonía del ritmo», confiriendo a su templo de madera todo un simbolismo esotérico. Con la sanguinaria Guerra Mundial, movimientos transgresores de las actuales corrientes del arte propician la aparición del Dada en Suiza o el De Stijl en los Países Bajos, cuya filosofía se basa en los influyentes principios metafísicos del filósofo místico holandés Spinoza (1632-1677)" en Nigel Pennick, "A Geometria Sagrada No Exilio," en Geometria Sagrada - Simbolismo E Intenção Nas Estruturas Religiosas (São Paulo: Pensamento, 1980).
} 
ción asiática aclamada por el maestro de la cultura japonesa Teitaro Suzuki. Amador Vega ofrece, asimismo, un interesante contrapunto entre la "nada relativa" en la que confluye la "tradición cristiana de raíz griega" y la "nada absoluta" de una cultura oriental que sabe no separar pensamiento, religión y ciencia. ${ }^{267}$ Tampoco Oteiza está fuera de estos ámbitos.

Oteiza indica la voluntad del artista por dotar su metafísica del arte de un contexto religioso fundado en las nociones de vacío y abismo, tan características de lo que podemos denominar un "nihilismo religioso" y que tan necesario se hacía de cara a obtener una estética negativa de carácter no substancialista o, en palabras suyas, una metafísica estética, es decir encarnada en el descenso hacia lo sensible, y que creemos estaría en condiciones de configurar toda una nueva antropología espiritual para nuestro tiempo. ${ }^{268}$

Este contexto místico, generalizado en todo el ambiente artístico, fomenta el rechazo de las formas ortodoxas y de toda la representación que la pintura viene arrastrando a lo largo de los últimos siglos. Se busca una realidad sentida, descifrada, no imitada. Con el cubismo y la desaparición de la perspectiva, se asiste por primera vez a la depuración de la realidad. La abstracción totalmente radical viene más tarde, de mano del suprematismo.

Sólo la osadía de estos autores, capaz de infringir las reglas y de ir más allá del sistema jerárquico de la mentalidad occidental, puede dar lugar a un cuadro "sin nada" o una partitura "sin notas". Para ellos, únicamente la ausencia de la forma tiene la capacidad de llegar a todas partes y comunicar con cualquier cosa. $^{269}$ La contribución de estos artistas, como afirma Cage, reside, sobre todo, en la construcción de un nuevo prototipo de artista derivado exclusivamente de su pensamiento y "que nada tenía que ver con el mito del héroe trágico representado en la figura de Jackson Pollock y que, en su búsqueda de métodos pragmáticos, se aproxima más a un buscador-científico que a un creador solipsista." 270 Artista que, como vaticina Barthes, desea desvincularse de las convenciones históricas que prohíben el azar y el caos como método compositivo; el mismo caos que lleva James Joyce a crear Ulysses y a Colón a descubrir América. Responsables de liberar el pensamiento de la pesada herencia de la memoria, proponen el error como forma de aprendizaje.

\footnotetext{
267 Oteiza, Quousque Tandem...! Ensayo de interpretación estética del alma vasca.

268 Oteiza, Quousque Tandem...! Ensayo de interpretación estética del alma vasca, 34.

269 François Jullien, Elogio de lo insípido: A partir de la estética y del pensamiento chino., trad. Anne-Hélêne Suárez Girard (Madrid: Siruela, 1998).

270 Daniel Farràs Berdejo, “John Cage," 2013, 28 de enero 2014, https://sites.google. com/site/llibretadapunts/contemporanietat/john-cage.
} 
Grado cero que se asocia con el errar, con el explorar la superficie encuadrada del soporte, al encuentro de la sorpresa de una configuración resonante (significante) en el seno del grupo pedagógico. Lo arquitectónico sin arquitectura, lo organizativo indefinido que reclama concreción. ${ }^{271}$

El grado cero y sus mecenas formulan una violenta ruptura con la comodidad de lo que se reconoce, donde, según la reflexión de James Joyce, un verdadero artista jamás se puede encerrar. A partir de esta limpieza ideológica, erige un bosque de incertidumbre donde el silencio, convertido en ruido, construye el extrañamiento.

A mediados del año 2015, Javier Seguí afirma con rotundidad que la imaginación siempre ha sido tema principal de toda su trayectoria investigadora en su propia práctica de dibujar.

Para él, el papel de la imaginación en los procesos pedagógicos reviste una importancia extrema, no sólo a la hora de enseñar, sino también de comprender. El maestro debe hallarse por encima de la burocracia y elevar al estudiante a la poética de la vida, seduciéndolo con su energía e inquietud.

La enseñanza actual parece fundamentarse todavía en la capacidad de memorizar datos y fórmulas. El pensamiento se transforma en una especie de prótesis informática: la memoria, al basarse en la percepción, no puede ser considerada un método infalible en la enseñanza. Ni la memoria ni la inteligencia pueden crear nada sin el auxilio de la imaginación. Sólo la intervención, la liberación del pasado y la capacidad de imaginar el futuro (imaginación) -o al menos un presente alternativo- pueden propiciar un conocimiento libre y autónomo.

Todo ser humano está capacitado para captar imágenes, para recordarlas; pero es la relación entre las imágenes la que causa el vértigo del saber adquirido. Imaginar lo invisible como si estuviera presente, creando nuevos horizontes de conocimiento. Por eso, tanto en pedagogía como en muchos otros ámbitos, la imaginación es el elemento fundamental para alejar la cotidianidad y permitir que rija la doctrina de los sueños y el deseo. La llamada "facultad inferior de error y falsedad"272, así como lo que propugna el clasicismo occidental, es en realidad lo que conmueve al individuo y le hace mirar hacia lo imaginario.

La imaginación no se halla aislada de su entorno -civilización, época, grupo social- ni de aspectos más íntimos -fisiología y 
personalidad individual- cuando se percibe un objeto, ya sea de manera directa o indirecta, se reconocen y asocian imágenes anteriores. El ser humano divaga, sueña y de maravilla o aterra con numerosas efigies mnémicas que transmiten toda una serie de temores, recuerdos, deseos y voluntades vinculados al hábitat que le sitúa en el tiempo y el espacio. Quienes crean arte tienen la capacidad de materializar esas imágenes, estructurando la actividad onírica en una realidad inédita.

Para el filósofo y educador Rudolf Steiner, la imaginación es el gran cosmos de los pensamientos que moldea el mundo exterior aparente, y la propia especie. El mundo exterior lo concibe la percepción, lo que sólo es posible si posteriormente se concibe. El pensamiento crea el universo interior y exterior en el que el ser humano se mueve. La imaginación genera imágenes, la inspiración les da vida y la intuición las almacena. En este ritual de constante activación de la imaginación, según Joseph Beuys siempre existe una alternancia entre profesor/estudiante: "todos tenemos tanto de profesor como de estudiante". ${ }^{273}$

La imaginación es lo más vivo y elemental del ser humano, no se puede parar. Si la imaginación no tiene alimento se consume a sí misma, y el resultado es una imaginación pobre y abandonada: "Contra esta soberbia, potencia enemiga de la razón, excepcionalmente se coaligan los sabios y el vulgo; el principal esfuerzo de la educación parece ser combatirla, y si no destruirla, por lo menos moderarla y contenerla". ${ }^{274}$

Javier Seguí, consciente de que la capacidad para imaginar tiende a disminuir cuando se impone la razón y que la imaginación requiere mantenimiento y práctica, propone una serie de ejercicios para estimular su funcionamiento. Teresa Artola González, doctora en Psicología por la Universidad Complutense de Madrid y experta en Asesoramiento Educativo Familiar, alerta de este problema en las escuelas: "El problema es que, por lo general, la escuela se ha centrado más en el desarrollo del pensamiento lógico, secuencial, analítico y racional en perjuicio del pensamiento intuitivo, imaginativo, fantasioso o soñador."275

Conocedora del procedimiento actual que siguen los profesionales de la enseñanza, la psicóloga menciona a Francisco Menchén Bellón, escritor e investigador de la creatividad, y su libro

\footnotetext{
273 Joseph Beuys y Rudolf Steiner, Imagination, Inspiration, Intuition. (1905-1980) (Australia: National Gallery of Victoria, 2007), 62.

274 Ludovic Dugas, La imaginación, trad. César Juarros (Madrid1905), 193.

275 Teresa Artola González y Jorge Barraca Mairal, "Creatividad e imaginación. Un nuevo instrumento de medida: la Pic," EduPsykhé: Revista de psicología y psicopedagogía $n^{\circ} 3$ (2004): 77.
} 
Descubrir la creatividad: desaprender para volver a aprender, ${ }^{276}$ según el cual, el desarrollo de la imaginación depende del fomento de la fantasía -impulsar percepciones y situaciones improbables-, de la intuición -basada en el conocimiento interiory de la asociación -acoplar ideas, palabras e imágenes de una manera novedosa- ${ }^{277}$

Para que esta facultad se desarrolle con agilidad, es preciso que exista una motivación inicial que facilite la emersión de la imaginación creativa; la legitimización del pensamiento divergente, que rompa con las convenciones y fomente lo absurdo y lo inútil sin un límite fijo de tiempo. ${ }^{278}$

Por este motivo, Seguí defiende a capa y espada la formación basada en la estimulación de la imaginación, como pilar de la enseñanza de la arquitectura y del hacer del arquitecto. Para estimular la imaginación, motor del hacer, propone diversas técnicas operativo-imaginarias. Aprender y enseñar a manejarlas con soltura resulta esencial para traducir esa imaginación y hacer que sea inteligible. La provisión de técnicas adecuadas, tanto para permitir ese viaje al interior como para expresar los descubrimientos realizados debe ser la principal misión del trabajo docente: "El arquitecto es un mediador interpretador, como el médico, el abogado, el gestor, etc. La mediación edificatoria es el ámbito del arquitecto. El dibujar es el asunto medial (comunicativo) del pensamiento". ${ }^{279}$

276 Francisco Menchen Bellon, Descubrir la creatividad: desaprender para volver a aprender (Madrid: Piramide, 2005).

277 González y Mairal, "Creatividad e imaginación. Un nuevo instrumento de medida: La Pic," 77.

278 González y Mairal, "Creatividad e imaginación. Un nuevo instrumento de medida: La Pic," 77.

279 Javier Seguí, Dibujar, proyectar (LXX) - Vacío, vaciar (5) (Madrid: Instituto Juan

Herrera de la Escuela de Arquitectura de Madrid, 2014), 17. 


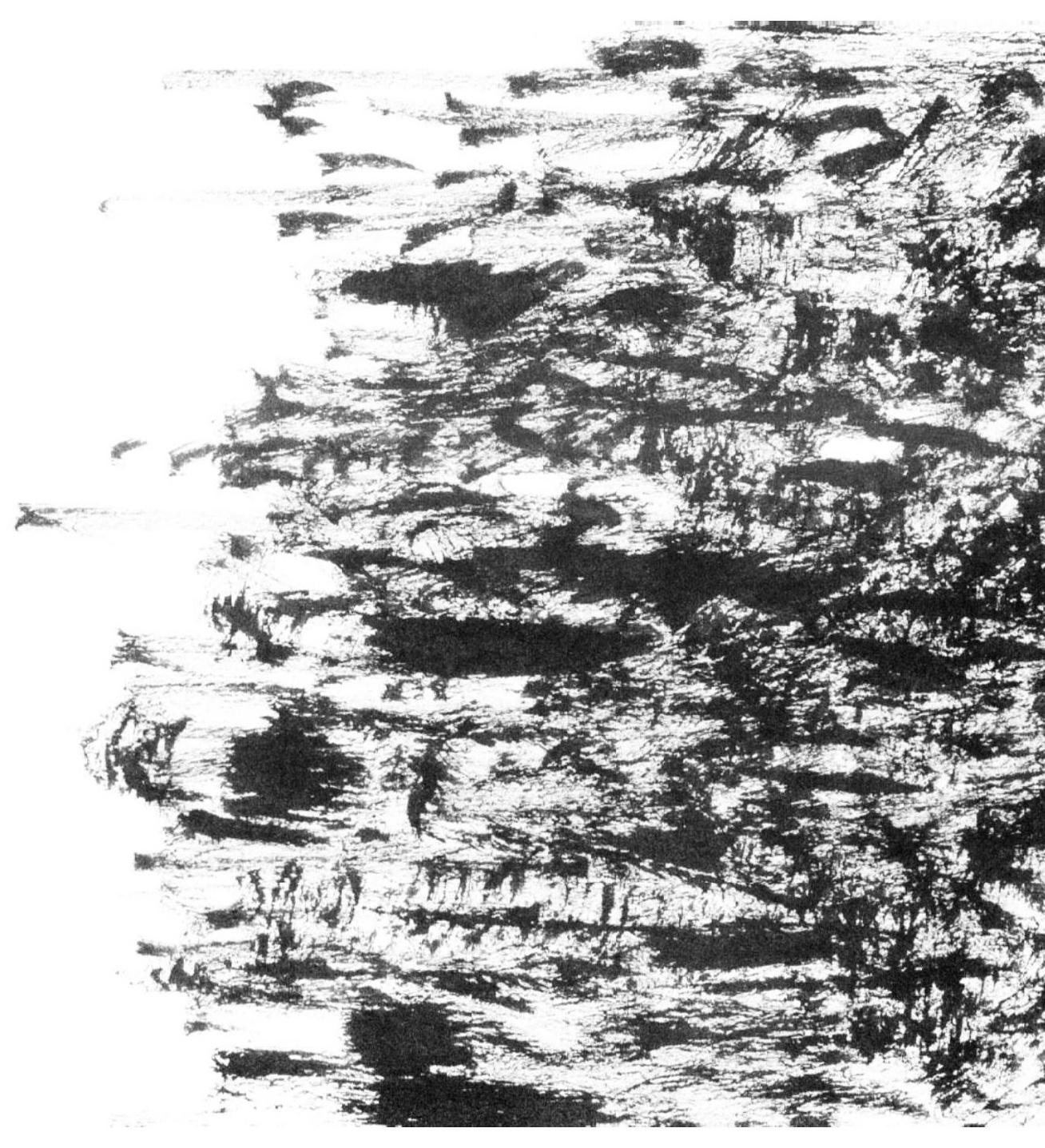




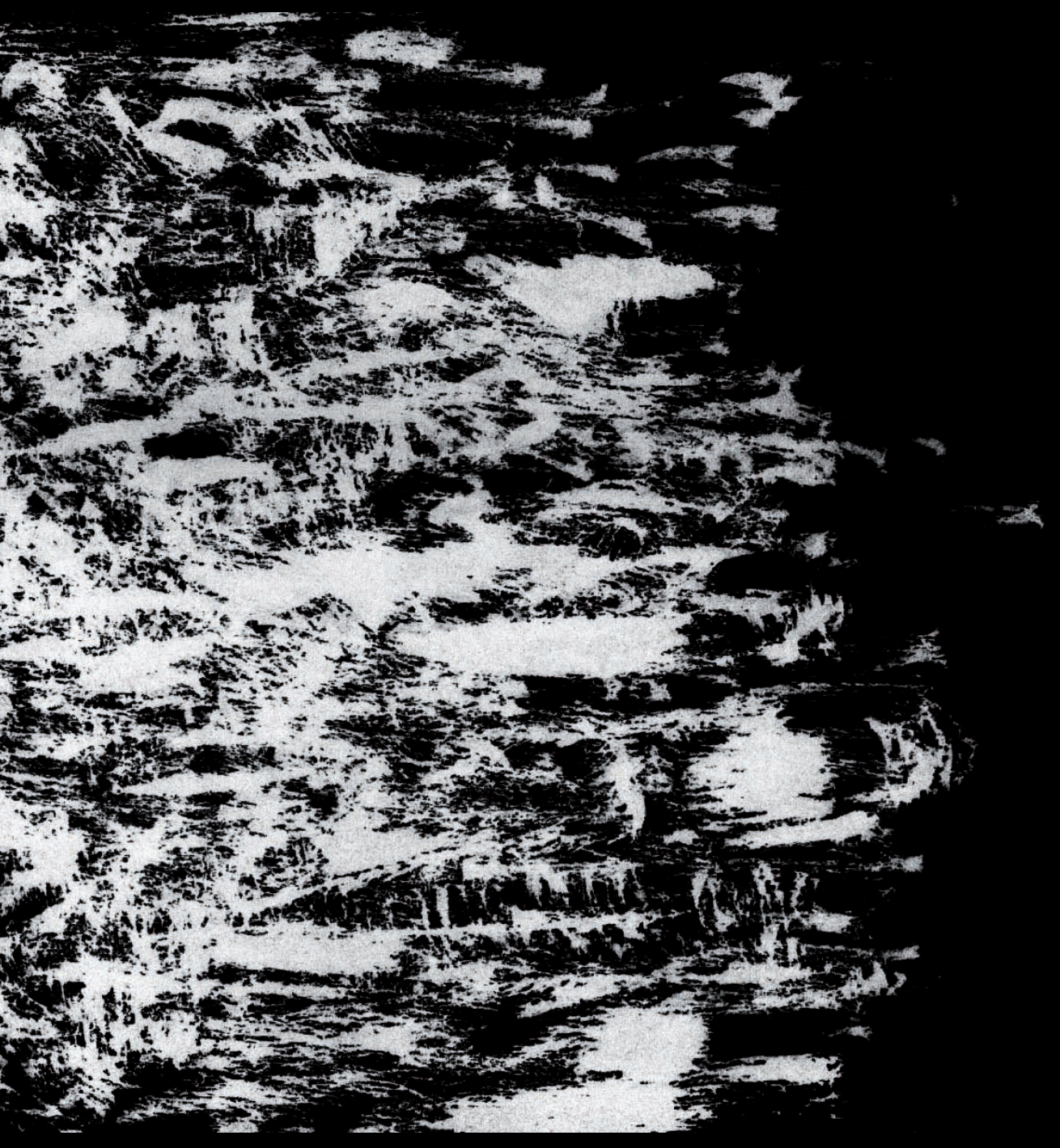


3. hacer 
A mediados del año 2015, Javier Seguí afirma con rotundidad que la imaginación siempre ha es el tema principal de toda su trayectoria investigadora en su propia práctica de dibujar.

Para él, el papel de la imaginación en los procesos pedagógicos reviste una importancia extrema, no sólo a la hora de enseñar, sino también de comprender. El maestro debe hallarse por encima de la burocracia y elevar al estudiante a la poética de la vida, seduciéndolo con su energía e inquietud.

La enseñanza actual parece fundamentarse todavía en la capacidad de memorizar datos y fórmulas. El pensamiento se transforma en una especie de prótesis informática: la memoria, al basarse en la percepción, no puede ser considerada un método infalible en la enseñanza. Ni la memoria ni la inteligencia pueden crear nada sin el auxilio de la imaginación. Sólo la intervención, la liberación del pasado y la capacidad de imaginar el futuro (imaginación) -o al menos un presente alternativo- pueden propiciar un conocimiento libre y autónomo.

Todo ser humano está capacitado para captar imágenes, para recordarlas; pero es la relación entre las imágenes la que causa el vértigo del saber adquirido. Imaginar lo invisible como si estuviera presente, creando nuevos horizontes de conocimiento. Por eso, tanto en pedagogía como en muchos otros ámbitos, la imaginación es el elemento fundamental para alejar la cotidianidad y permitir que rija la doctrina de los sueños y el deseo. La llamada "facultad inferior de error y falsedad"280 , así como lo que propugna el clasicismo occidental, es en realidad lo que conmueve al individuo y le hace mirar hacia lo imaginario.

La imaginación no se halla aislada de su entorno -civilización, época, grupo social- ni de aspectos más íntimos -fisiología y personalidad individual- cuando se percibe un objeto, ya sea de manera directa o indirecta, se reconocen y asocian imágenes anteriores. El ser humano divaga, sueña y de maravilla o aterra con numerosas efigies mnémicas que transmiten toda una serie de temores, recuerdos, deseos y voluntades vinculados al hábitat que le sitúa en el tiempo y el espacio. Quienes crean arte tienen la capacidad de materializar esas imágenes, estructurando la actividad onírica en una realidad inédita.

Para el filósofo y educador Rudolf Steiner, la imaginación es el gran cosmos de los pensamientos que moldea el mundo exterior aparente, y la propia especie. El mundo exterior lo concibe la percepción, lo que sólo es posible si posteriormente se conci- 
be. El pensamiento crea el universo interior y exterior en el que el ser humano se mueve. La imaginación genera imágenes, la inspiración les da vida y la intuición las almacena. En este ritual de constante activación de la imaginación, según Joseph Beuys siempre existe una alternancia entre profesor/estudiante: "todos tenemos tanto de profesor como de estudiante". ${ }^{281}$

La imaginación es lo más vivo y elemental del ser humano, no se puede parar. Si la imaginación no tiene alimento se consume a sí misma, y el resultado es una imaginación pobre y abandonada: "Contra esta soberbia, potencia enemiga de la razón, excepcionalmente se coaligan los sabios y el vulgo; el principal esfuerzo de la educación parece ser combatirla, y si no destruirla, por lo menos moderarla y contenerla". ${ }^{282}$

Javier Seguí, consciente de que la capacidad para imaginar tiende a disminuir cuando se impone la razón y que la imaginación requiere mantenimiento y práctica, propone una serie de ejercicios para estimular su funcionamiento. Teresa Artola González, doctora en Psicología por la Universidad Complutense de Madrid y experta en Asesoramiento Educativo Familiar, alerta de este problema en las escuelas: "El problema es que, por lo general, la escuela se ha centrado más en el desarrollo del pensamiento lógico, secuencial, analítico y racional en perjuicio del pensamiento intuitivo, imaginativo, fantasioso o soñador."283

Conocedora del procedimiento actual que siguen los profesionales de la enseñanza, la psicóloga menciona a Francisco Menchén Bellón, escritor e investigador de la creatividad, y su libro Descubrir la creatividad: desaprender para volver a aprender, según el cual, el desarrollo de la imaginación depende del fomento de la fantasía -impulsar percepciones y situaciones improbables-, de la intuición -basada en el conocimiento interiory de la asociación -acoplar ideas, palabras e imágenes de una manera novedosa-. ${ }^{284}$

Para que esta facultad se desarrolle con agilidad, es preciso que exista una motivación inicial que facilite la emersión de la imaginación creativa; la legitimización del pensamiento divergente,

\footnotetext{
281 Joseph Beuys y Rudolf Steiner, Imagination, Inspiration, Intuition. (1905-1980) (Australia: National Gallery of Victoria, 2007), 62.

282 Ludovic Dugas, La imaginación, trad. César Juarros (Madrid1905), 193.

283 Teresa Artola González y Jorge Barraca Mairal, "Creatividad e imaginación. Un nuevo instrumento de medida: la Pic," EduPsykhé: Revista de psicología y psicopedagogía n०3 (2004): 77.

284 González y Mairal, "Creatividad e imaginación. Un nuevo instrumento de medida: La Pic," 77.
} 
que rompa con las convenciones y fomente lo absurdo y lo inútil sin un límite fijo de tiempo. ${ }^{285}$

Por este motivo, Seguí defiende a capa y espada la formación basada en la estimulación de la imaginación, como pilar de la enseñanza de la arquitectura y del hacer del arquitecto. Para estimular la imaginación, motor del hacer, propone diversas técnicas operativo-imaginarias. Aprender y enseñar a manejarlas con soltura resulta esencial para traducir esa imaginación y hacer que sea inteligible. La provisión de técnicas adecuadas, tanto para permitir ese viaje al interior como para expresar los descubrimientos realizados debe ser la principal misión del trabajo docente: "El arquitecto es un mediador interpretador, como el médico, el abogado, el gestor, etc. La mediación edificatoria es el ámbito del arquitecto. El dibujar es el asunto medial (comunicativo) del pensamiento". ${ }^{286}$

285 González y Mairal, "Creatividad e imaginación. Un nuevo instrumento de medida: La Pic," 77.

286 Javier Seguí, Dibujar, proyectar (LXX) - Vacío, vaciar (5) (Madrid: Instituto Juan Herrera de la Escuela de Arquitectura de Madrid, 2014), $17 .$. 


\subsection{Proyectar, dibujar, escribir}

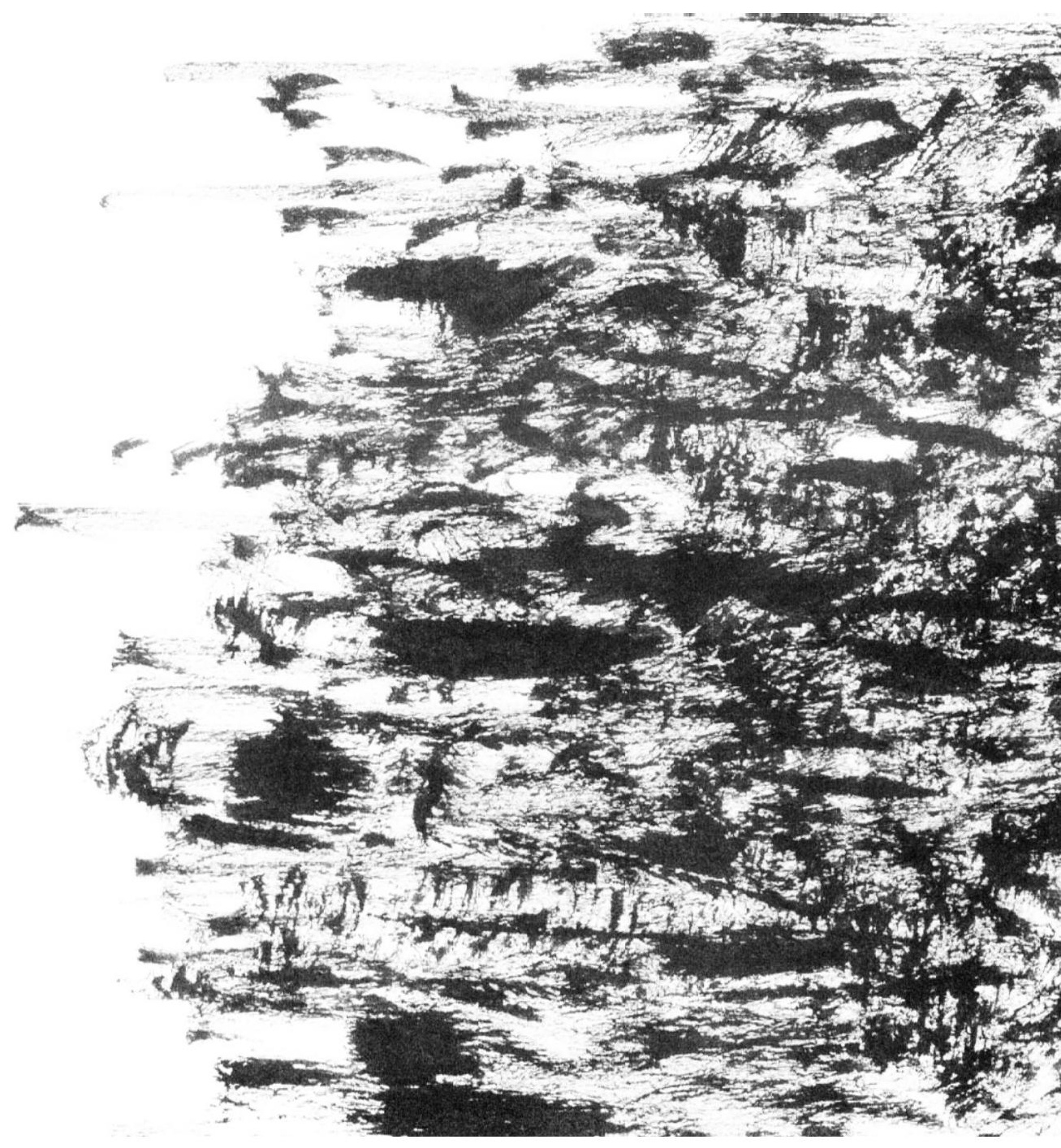


En cierto modo dibujar y escribir constituyen la misma acción: actividad desarrollada en el espacio y el tiempo en la que alguien deja una huella. Poco afecta a la acción si este movimiento se realiza en un monitor, sobre un papel, en la piel o en la arena de la playa. Ni si se pretende comunicar o liberarse de un pensamiento; o incluso si se trata de un simple acto mecánico. Y por supuesto, menos importante es todavía si algo se parece a algo o no: son líneas, manchas, trazos que dejan huella en el vacío, o la huella de los vacíos extraídos del Todo. ${ }^{287}$
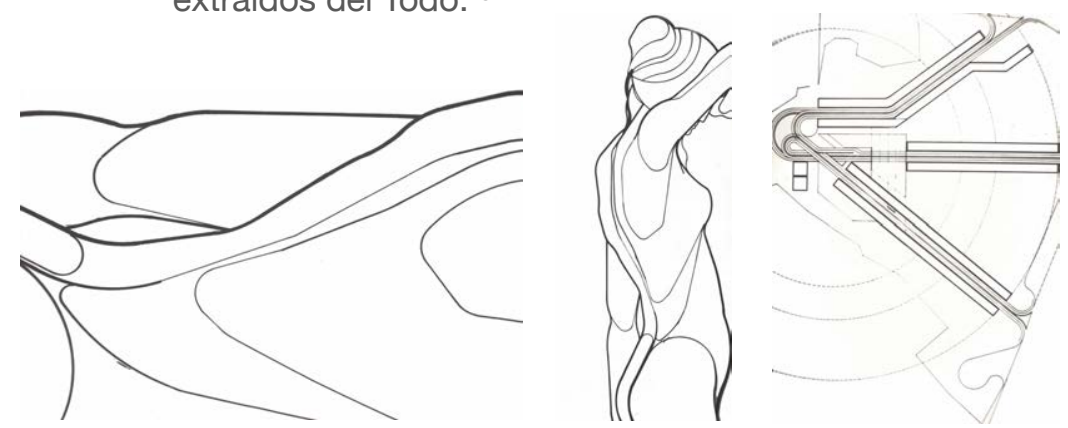

DIBUJOS ARTE Y CONOCIMIENTO,(antes de 2000). Javier Seguí.

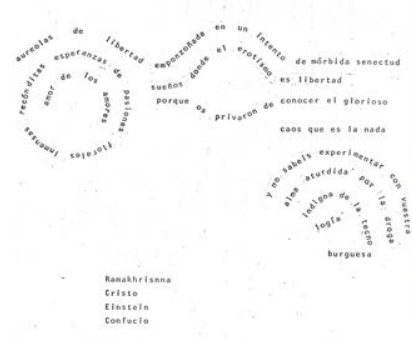

POESIA VISUAL, (1965-1977). Javier Seguí.

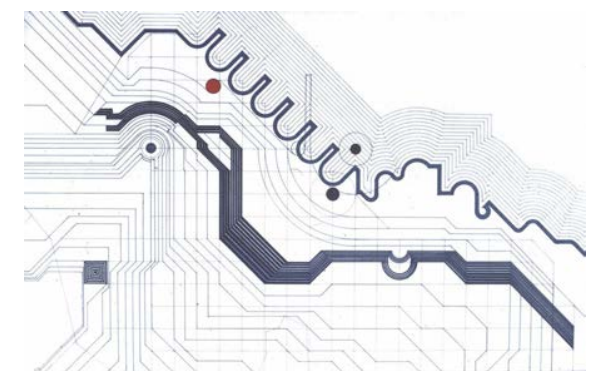

PROYECTO CLUB SOCIAL DE VALDEMORILLO, (1973). Javier Seguí.

Proyectar, dibujar y escribir son acciones que requieren dinamismo. Del proceso dinámico, de su movimiento, resulta la obra terminada, pero ya liberada de la verdadera esencia de su creación artística: el gesto. "Por eso dibujar y escribir se complementan... se refuerzan. Dibujar es desvelar cadáveres. Escribir es diseccionarlos para buscar el contra vitalizador."288

Es en el movimiento donde reside la verdadera esencia de una obra de arte. El resultado final de ese "movimiento", el objeto inanimado, secundario, es inverso a la propia obra de arte, y despierta un profundo desinterés en Seguí. No le importa el resultado final o lo que se intenta representar, sino el recorrido y las tensiones de su hacer.

287 Atxu Amann y Gonzalo Pardo, "Reinventarse o morir. DAI 1 En la ETSAM," Ega 21 (2013): 260.

288 Javier Seguí, Dibujar, proyectar (LVII) - Arte y muerte (2) (Madrid: Instituto Juan Herrera de la Escuela de Arquitectura de Madrid, 2012), 29. 
Aristóteles afirma que "para conocer las cosas que queremos hacer, hay que hacer las cosas que queremos saber"289. Pareyson dice, incluso, que "el arte es un hacer tal que mientras haces se inventa el modo de hacer". ${ }^{290}$ Para Valéry la "poiesis busca la verdad allí donde el hombre con su hacer la ha construido". ${ }^{291}$
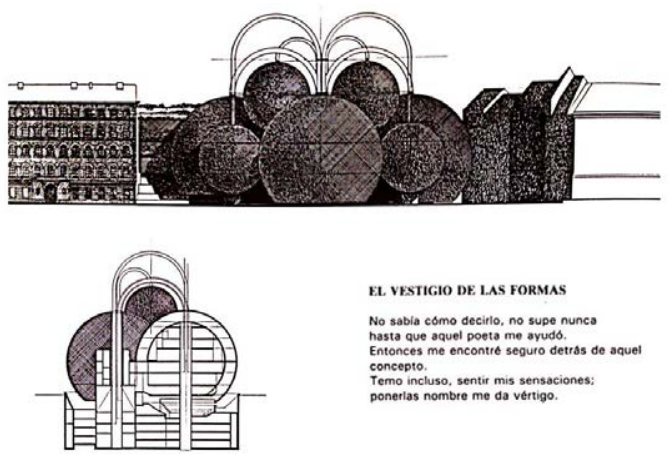

EDIFICIO DE OFICINAS EN VIENA, (1976). Javier Seguí con la colaboración de Carlos Sevilla, Adolfo Suárez, F. Tascón, J. L. Posada, J. Vizcaíno y J. J. Torrenova.

En este sentido Javier Seguí reflexiona y afirma que "cuando se hace, no se puede pensar, y cuando se piensa, no se puede hacer. Resulta que cuando te pones a hacer, tienes que cortar ese flujo. Tienes que dejar que tu cuerpo, que también tiene sus diagramas y su memoria, de alguna manera se ponga a actuar". ${ }^{292}$

El conocimiento sólo se alcanza con la experiencia del hacer, es decir, con un trabajo continuo y obstinado hasta su materialización. Picasso no para de "hacer" porque es necesario garantizar que "cuando llegue la inspiración que me encuentre trabajando". 293

Desde sus tiempos de estudiante, como se menciona anteriormente, Seguí cuenta con un procedimiento habitual para operar en el ámbito creativo. Tiene la costumbre de asociar un proyecto o una imagen a un poema. La revista Kain, de 1988, dedica el número tres al completo, a exponer todos sus proyectos desde 1964 hasta $1983 . .^{294}$

Seguí tiene claro que cualquier acción en sí misma supone un movimiento, que es el proyecto motriz de toda la obra artística.

\footnotetext{
289 Jorge Sarquis, Itinerarios del proyecto 1. Ficción epistemológica (Buenos Aires: Editorial Nobuku, 2003), 58.

290 Sarquis, Itinerarios del proyecto 1. Ficción epistemológica, 58.

291 Sarquis, Itinerarios del proyecto 1. Ficción epistemológica, 58.

292 Javier Seguí, entrevistado por Maria Brito, 17 de diciembre, 2013, Grabación.

293 Joan Calduch Cervera, Pensar y hacer la arquitectura: una introducción (San Vicen-

te: Editorial Club Universitario, 2013), 24.

294 Juan Daniel Fullaondo, “Javier Seguí (1964-1983)," Kain 1988,
} 
Ferrater Mora recurre a Heidegger, Ortega y Gasset y Jean-Paul Sartre para entender la definición de proyecto.

Heidegger (...) el proyecto no es aquí simplemente un plan, por la sencilla razón de que no se trata de planear, disponer o proyectar lo que se va a hacer. (...) En otros términos, más que de vivir proyectando se trata de vivir como proyecto. El proyecto es, pues, una anticipación de sí mismo. (...) Ortega y Gasset, especialmente en sus abundantes referencias a la vida como "programa vital" y como "el problema de sí misma". (...) Pero, a diferencia de Heidegger, Ortega entiende este quehacer en que consiste la vida como algo más concreto: el proyecto como quehacer es "lo que hay que hacer", y éste está de algún modo condicionado por una situación concreta. (...) Para Jean- Paul Sartre, hay un "proyecto inicial" que está constantemente abierto a toda modificación, de modo que se trata, en rigor, de un proyecto que es siempre, por decirlo así, "pre-proyecto". El proyecto no está nunca constituido, porque si tal ocurriera dejaría de ser proyecto; el proyecto es tal sólo porque es conciencia de libertad absoluta. ${ }^{295}$

De su afirmación se deduce que el proyecto, tanto para Heidegger como para Ortega o Sartre, es una auto-proyección del imaginario bajo el lenguaje de la escritura o del dibujo. Del imaginario emana la esencia de la obra, pero es en la forma creativa de expresarlo, donde reside su originalidad.

Proyectar, dibujar y escribir, como todas las actividades artísticas e intelectuales, se desarrollan en ese "hacer", en ese movimiento cinético, casi involuntario, ideado en el imaginario y orquestado por las pasiones y las emociones que, proyectadas en los gestos del cuerpo, lo hacen real.

\begin{abstract}
Yo he estado siempre, y también la cultura ha ido por ahí, en el hecho de entrar en el hacer. En el interior de la práctica. ¿Qué pasa cuando estás haciendo? No el hecho, sino el hacer, el propio hacer. Y el propio hacer se basa en esas cosas. Es pura fluidez. En ese sentido, probablemente, el dibujo que sale se ajusta directamente, no creo que tanto a las palabras, si no que se ajusta un poco a ese fluir. Es una tensión que no sabes de dónde viene y te mantiene vivo, te va transportando, y la sensación de sentirte transportado, y de sentirte acompañado en ese transporte. ${ }^{296}$
\end{abstract}

Sólo "haciendo" se aprende: no se trata de tener una idea sino de ponerla en marcha. Sólo el "hacer" exhaustivo puede madurar la experiencia y dotar al conocimiento de herramientas con-

295 Ferrater Mora,Diccionario de filosofia (Buenos Aires: Editorial Sudamerica, 1965), 500.

296 Javier Seguí, entrevistado por Maria Brito, 21 de enero, 2014. 
sistentes para un discurrir creativo y productivo.

A su vez, al hacer que algo suceda más de una vez, tenemos un objeto a evaluar y las variaciones en ese acto de magia permiten explorar la igualdad y la diferencia: la práctica se convierte en narración más que en mera repetición digital; los movimientos que se consiguen con esfuerzo van siendo asimilados cada vez más profundamente en el cuerpo; el ejecutante avanza lentamente hacia una mayor destreza". ${ }^{297}$

Cuando termina el "hacer", la obra pierde su movimiento y muere. Javier Seguí afirma que "las obras terminadas son cadáveres, están muertas". ${ }^{298}$ Bachelard matiza diciendo que "(...) una imagen estable y acabada corta las alas a la imaginación soñadora, que no se encierra en ninguna imagen... lo imaginario decanta imágenes, pero se presenta como algo que está siempre más allá". ${ }^{299}$

En su libro El aire y los sueños, Bachelard asegura que la imaginación no forma imágenes, sino que las deforma; las une de manera inesperada, porque las imágenes acabadas ya no dejan soñar, hacen actuar porque pierden su trazado cinético y llegan a su estación final. Su hermético simbolismo olvida ese viaje mágico hacia el imaginario. Bachelard habla del aire como símbolo de la imaginación dinámica que acerca a ese espacio sin dimensiones, ese no-lugar de la materia:

Desde nuestro particularísimo punto de vista, el hábito es la antítesis exacta de la imaginación creadora. La imagen habitual detiene las fuerzas imaginantes. La imagen aprendida en los libros, vigilada y criticada por los profesores, bloquea la imaginación. ${ }^{300}$

En este ensayo de Bachelard, las imágenes aéreas se evaporan y cristalizan en la dicotomía del sueño y del pensar: "(...) no se vuela porque se tengan alas, se crean unas alas porque se ha volado", 301 "(...) en el sueño no se vuela para ir al cielo; se sube al cielo porque se vuela". ${ }^{302}$

Haciendo se aprende y se conoce. Cuando el "hacer" se transforma en "hecho", surge una nueva realidad artística.

\footnotetext{
297 Richard Sennett, El artesano, trad. Marco Aurelio Galmarini (Barcelona: Editorial Anagrama, 2009), 198.

298 Javier Seguí, entrevistado por Maria Brito, 10 de diciembre, 2013, Grabación.

299 Gastón Bachelard, El aire y los sueños - Ensayo sobre la imaginación del movimien-

to, trad. Ernestina de Champorcine (México: Fondo de Cultura Economica, 1993), 10.

300 Bachelard, El aire y los sueños - Ensayo sobre la imaginación del movimiento, 22.

301 Bachelard, El aire y los sueños - Ensayo sobre la imaginación del movimiento, 40.

302 Bachelard, El aire y los sueños - Ensayo sobre la imaginación del movimiento, 46.
} 
Llega un momento en que el dibujo se desprende de ti, se convierte en otra cosa; tú estás fuera de él. Pero es que además el dibujo, para que sea dibujo, necesita expulsarte. Que es también el grado cero. Haces algo con la consciencia de que tú vas a desaparecer. O sea, lo que queda es una huella completamente anquilosada. En este sitio ya no estás. Dice Foucault en un momento determinado, que "el escritor es el que elige el modo de ausentarse de su obra." Todo el arte, en el fondo, es una forma de estudiar como desaparecer de lo que estás haciendo. ${ }^{303}$

\section{Sobre estas afirmaciones, Lobo Antunes, referencia permanente de Javier Seguí, opina que "un libro se escribe a sí mismo"; sólo hay que darle el cuerpo para que se pueda expresar.}

Un libro se escribe a sí mismo (...) la principal dificultad con el libro que estoy escribiendo consiste en que pensé demasiado en la novela, sin haber dejado espacio para que la novela se pensase a sí misma. Y, cuando uno piensa, piensa por fuera, mientras que cuando el libro se piensa a sí mismo (y uno allí, vigilante) se piensa por dentro. La obra es autónoma y no admite intromisiones del autor, por lo menos durante las dos o tres primeras versiones. (...) Es necesario comprender que no es importante entender lo que se hace, puesto que lo que se hace se entiende y articula y se basta de acuerdo con sus propias reglas, que no son las nuestras (afortunadamente) y nos necesita sólo como una especie de intermediarios entre dos instancias que se nos escapan y no nos hacen ni caso. Me siento a la mesa y me quedo esperando: es así como trabajo. (...) Los capítulos se van construyendo despacio, con una ciega sucesión inevitable. El material confluye, se junta, cambia de color, de textura, de dirección, toma forma, concierta, penosamente, sus varios elementos, a medida que la cabeza, que ya no entra en él, desarrolla una actividad paralela, siguiéndolo de lejos, como un perro de rebaño sin darle gran importancia a la voluntad de las ovejas pero, a pesar de todo, con una importancia que las ovejas sienten. Horacio llamaba a esto "un bello desorden precedido del furor poético". Lo que queda, en esas primeras versiones, es un magma: por debajo del magma está el libro. (...) Quien inicia un trabajo sabiendo lo que va a hacer hace mal, lo hace idéntico al anterior. (...) Escribir (o pintar, o componer) consiste en llevar hacia arriba. ${ }^{304}$

\section{Consciente de esta realidad, Javier Seguí no para de "hacer".}

\footnotetext{
303 Seguí, 21 de enero, 2014.

304 António Lobo Antunes, "A pie de página - Explicación a los paisanos," El País, 23 de agosto 2003. En Javier Fco. Raposo, "Recopilación, estructuración y análisis de los documentos básicos manejados y elaborados en la cátedra de Análisis de Formas Arquitectónicas de la E.T.S.A.M a partir de los años 70. Aplicación a una nueva pedagogía." (Universidad Politécnica de Madrid, 2004).
} 
Su labor profesional como arquitecto empieza en 1964, año en que termina la carrera, y desarolla su último proyecto en el año 2006, cuatro años antes de su jubilación. Su currículo cuenta con cuarenta y ocho anteproyectos y cincuenta y nueve proyectos y realizaciones.

Pero también son muchas sus aportaciones en los universos del "dibujar" y el "escribir".

Hoy en día, su archivo de dibujos digitalizados cuenta con más de setenta mil elementos. Parece una misión casi imposible intentar clasificar toda la obra gráfica, que sólo en su ordenador ocupa veinte gigabytes. En esa carpeta de dibujos almacena los textos y las anotaciones que siempre acompañan su producción gráfica. Seguramente este número no representa toda la producción, que comienza en 1950, cuando ingresa, con diez años, en una academia de dibujo, y que no se detiene a lo largo de su vida. Una obra ingente de la que, además, se pierde parte en los incendios que se producen en sus estudios.

Para ilustrar de la magnitud de su obra, basta con decir que sólo a partir de 2010 -año en que se jubila, que marca un incremento sustancial de su producción- y hasta la actualidad, se contabilizan ciento cuarenta y cinco cuadernos de dibujos. Estos datos arrojan un promedio de veintinueve cuadernos de ochenta hojas al año.

También escribir es una acción compulsiva para Seguí. En el directorio de carpetas y archivos de su ordenador se almacena todo tipo de textos: documentos académicos, proyectos de investigación, cartas, artículos en publicaciones, congresos y resúmenes de centenares de libros.

Escribir es, desde siempre, otra forma de dejar vestigios a lo largo de su recorrido. En su curriculum vitae, de cuarenta y nueve páginas, se puede apreciar que comienza a publicar en 1961, cuando sólo tiene veintiún años. Seguí continúa haciéndolo hasta 2015 , siendo su último trabajo un garabato a mano, con una pluma, en su círculo: Los dibujos de J. Villota, aún sin publicar.

Dado el elevado número de textos, Javier Seguí decide crear en su currículo dos apartados distintos, con cerca de doscientas ochenta y cinco publicaciones en total.

Al primero de estos apartados lo denomina "Publicaciones (artículos y capítulos de libros)". Su primera publicación es "Proyecto y viviendas", escrita para la Revista Nacional de Arquitectura en 1961, la primera de un total de noventa y cinco. Seguí escribe para revistas del ámbito artístico, pero, sobre todo, para institu- 
ciones académicas de todo el mundo: París y Lovaina la Nueva (Francia); Zagreb (Yugoslavia); Nueva York (E.E.U.U.); Bucarest (Rumanía); Roma, Nápoles, Turín y Florencia (Italia); Lisboa (Portugal); Veracruz (México); São Paulo y Alagoas (Brasil).

El segundo apartado, titulado "Publicaciones (libros y monografías)", comprende ciento noventa publicaciones, la mayoría difundidas por el Instituto Juan Herrera. La primera publicación, Estética cibernética, en Ordenadores en el arte, data de 1969, cuando todavía se encuentra en el Centro de Cálculo de la Universidad Complutense de Madrid, y es la primera de los casi dos centenares actuales.

El impresionante número de publicaciones oficiales que figuran en su extenso currículo probablemente no incluya todos los textos que Seguí produce a lo largo de su vida. Habría que añadir los poemas, las cartas, los documentos personales, las reflexiones que nunca salen de sus cuadernos personales.

Lo más significativo de este apartado son las publicaciones del Instituto Juan Herrera, que se dividen en cuatro bloques temáticos: Dibujar, proyectar (setenta y dos libros), Mitos y fantasías arquitectónicas (siete libros), La cultura del proyecto (nueve libros) y Encuentros (veinticinco libros).

El bloque Dibujar, proyectar recoge sus lecturas, sus reflexiones acerca de la acción de dibujar y proyectar. Mitos y fantasías arquitectónicas engloba una investigación dedicada a identificar los mitos y fantasías en las edificaciones. En La cultura del proyecto se recopilan las conversaciones mantenidas con varios profesionales destacados de la arquitectura a lo largo de los diversos cursos de doctorado que imparte en la Escuela para intentar analizar desde dentro cómo acometen estos profesionales el proyectar. El último grupo, Encuentros, reúne sus textos más literarios, más poéticos, situaciones que vive y por las que pasa. Éstos no tienen tanto que ver con lo profesional, como con lo vital. Sin embargo no tienen carácter de diario, y sí de acontecimiento.

Además de los libros Sobre dibujar y proyectar, Ser dibujo y Oscuridad y Sombra: experiencias en dibujo y arquitectura, que empieza en 2004, hay un total de ciento catorce monografías y cerca de cuatro mil setecientas ochenta y una páginas. Si se hace un cálculo simbólico, una tesis doctoral tiene aproximadamente cuatrocientas páginas, lo que significa que en los diez últimos años Javier Seguí escribe el equivalente a doce tesis doctorales.

No se debe olvidar, sin embargo, que escribir sólo es posible mediante estímulos provocados por la lectura, por la forma sin- 
gular de sumergirse y organizar escenarios. De este axioma se desprende que Javier Seguí es un escritor apasionado porque también es un devorador de libros. Los datos que aquí se aportan sirven para aclarar la compulsión con la que lee y con la que plasma con su pluma las inquietudes que le atormentan.

Como resultado de esta lectura compulsiva, Javier Seguí dedica parte de su tiempo a escribir sobre lo que lee. Trata de hacer constar apuntes, fragmentos y sensaciones que guarda cuando termina un libro y no quiere olvidar. Estos resúmenes empiezan a consolidarse en 1993, y, a día de hoy, engloban seiscientos ochenta y un libros. A juzgar por estas cifras, en los últimos veintidós años, Seguí lee una media superior a un libro cada quince días.

En 2015 Javier Seguí muestra con cierto orgullo un gráfico publicado por la revista EGA en el que se hace patente que Javier Seguí es, de todos los que colaboran en la revista, el que más textos tiene publicados - doce en total.

Ya antes, en 2010, con la publicación de Aportaciones al XII Congreso Internacional de Expresión Gráfica Arquitectónica, celebrado en Madrid del 29 al 31 de mayo de 2008, Seguí encabeza la lista de los autores más leídos en las comunicaciones del congreso.
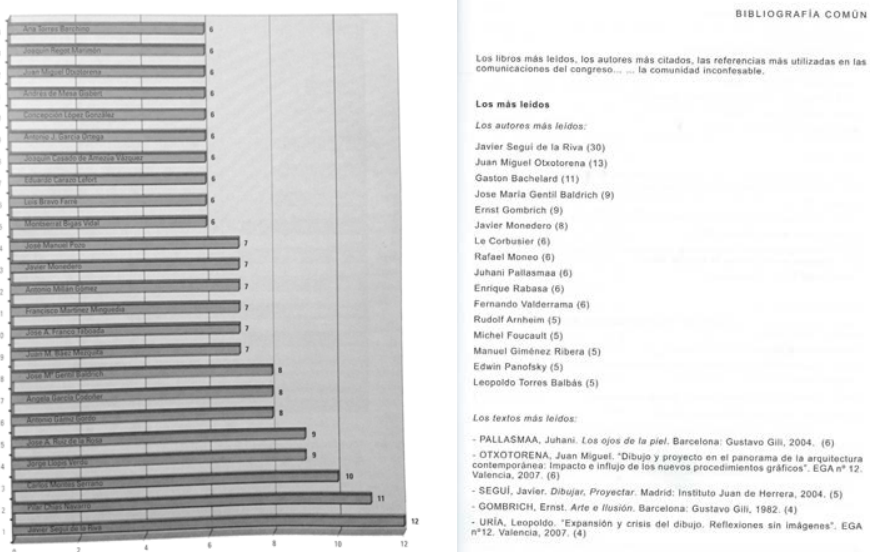

De izquierda a derecha: ASIDUIDAD DE LOS ESCRITORES. Revista EGA, n 25. BIBLIOGRAFIA COMÚN. Aportaciones al XII Congreso Internacional EGA. Lista de los libros más leídos, los autores más citados, las referencias más utilizadas en las comunicaciones del congreso ${ }^{305}$.

Su pasión por la escritura y por la lectura remiten a una de las referencias -ya citadas- de Javier Seguí: El Príncipe Valiente. Las imágenes que aquí aparecen le llaman la atención por diversos 
motivos, si bien lo que en definitiva le fascina es la posibilidad de que exista "una comunidad de amigos-amantes, de lectores-artistas", que coparticipa en conjunto de una libertad creadora. ${ }^{306}$

La Enciclopedia, de Diderot, se sumergía en este tema reconociendo desde el primer momento los límites humanos más básicos, esto es, los del lenguaje a la hora de expresar las operaciones del cuerpo humano, en especial las del artesano en el trabajo. Ni el trabajador ni el analista del trabajo pueden explicar lo que realmente ocurre. ${ }^{307}$

\subsubsection{PROYECTAR}

Inspirado en su imagen-fuerza de Camelot, que siempre puebla su imaginario, en 1964 Seguí funda, junto con Manolo de las Casas, Santiago López -ambos ya fallecidos- y su esposa Ana Buenaventura, un estudio de arquitectura situado en la calle Álvarez de Castro. En 1985, después de que su estudio sea pasto de las llamas, trabaja también con Manuel Berlanga, Pedro Burgaleta y Antonio Verd, todos ellos profesores de dibujo en la E.T.S.A.M. El objetivo que persigue como arquitecto es el mismo que persigue como docente: "una aventura colectiva de inventar lo arquitectónico dialógico comunal". ${ }^{308}$
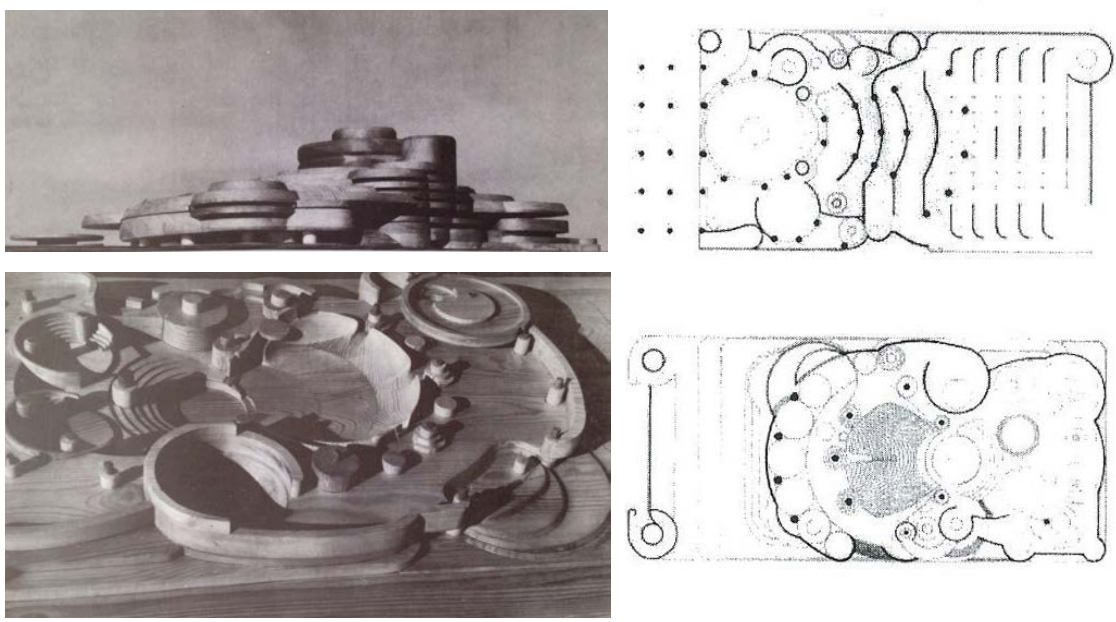

CONCURSO TEATRO DE LA ÓPERA DE MADRID, (1964).

J. Seguí, J. Carvajal, M. Casas y S. López.

\footnotetext{
306 Javier Seguí, "Camelot (2) (10/07/2010)," (Madrid: Instituto Juan Herrera de la Escuela de Arquitectura de Madrid, 2010).

307 Sennett, El artesano, 133.

308 Seguí, "Camelot (2) (10/07/2010)."
} 
Si bien su trayectoria académica parece presagiar el éxito profesional, Javier Seguí, uno de los arquitectos más destacados de la denominada "Generación del 68", no llega nunca a alcanzar la categoría de arquitecto de referencia.

\begin{abstract}
Entre 1964 y 1965, acaso pagando un alto precio a su intransigencia creadora, la reseña de sus realizaciones registra, únicamente, dos pequeñas obras construidas, la decoración de una farmacia y una pequeña villa en Buitrago. Entre 1966 y 1971 , solamente construye doce obras de nueva planta y dos reformas, en general bastante reducidas presupuestariamente. ${ }^{1}$
\end{abstract}

Como ya se ha mencionado, en 1985 un incendio que se declara en su estudio destruye todo el material gráfico que Javier Seguí tiene archivado hasta el momento. Tres años más tarde (1988) la revista Kain publica algunos documentos gráficos -expuestos a continuación-, con escasa calidad, que son vestigios parciales rescatados del incendio. Son propuestas de los proyectos carismáticos y los concursos irreverentes que más marcan a Seguí, aunque nunca llegan a convertirse en realidad. Sin embargo, inspirado por Jean-Yves Jounnais, Seguí asegura en un tono irónico que, al final, las mejores obras nunca son construidas.

Uno de los proyectos que logra llevar hasta su ejecución final y que, incluso, es publicado en la revista El croquis, corresponde a su primer encargo profesional (1964); una vivienda unifamiliar en Talavera de la reina, Toledo.
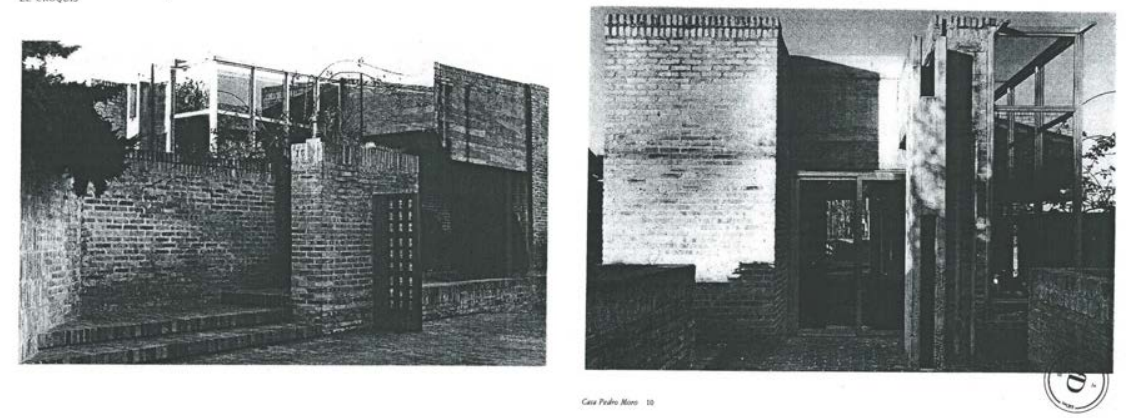

VIVIENDA UNIFAMILIAR, Talavera de la Reina, España, (1964). J. Seguí.

Un proyecto emblemático que Seguí recuerda con emoción es la ambiciosa propuesta experimental de 1973, que realiza cuando ya ocupa la cátedra de Análisis de Formas: el Club Social de Valdemorillo (Ciudad de las Flores); no obstante, tampoco tiene continuidad.

Deliberada, creciente, voluntad de distanciamiento de los niveles físicos, de una materialización constructiva de los 
proyectos. (...) Hay algo en el Javier Seguí de la época que plantea una suerte de distanciamiento de la realidad, de una cierta realidad, distanciamiento, no sé hasta qué punto brechtiano, encaminando hacia perspectivas sensiblemente más inmateriales, tenues, teóricas. ${ }^{2}$
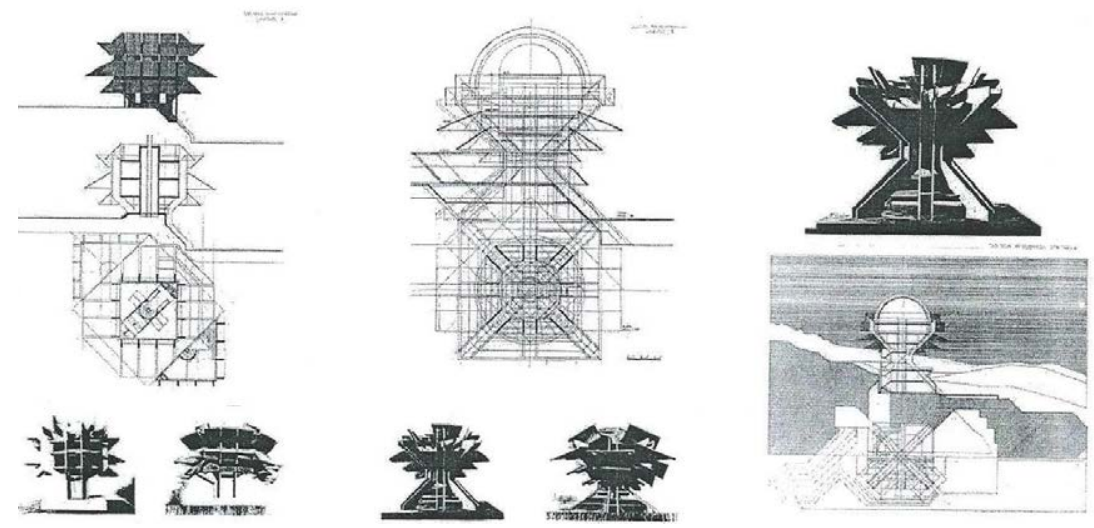

CLUB SOCIAL VALDEMORILLO, (1973). Javier Seguí.

A pesar de no ganar ningún concurso, Javier Seguí destaca con cierto regocijo las menciones accésit para la Universidad de Barcelona, la Politécnica de Valencia y el Palacio de Justicia de la Comunidad Vasca (Bilbao).

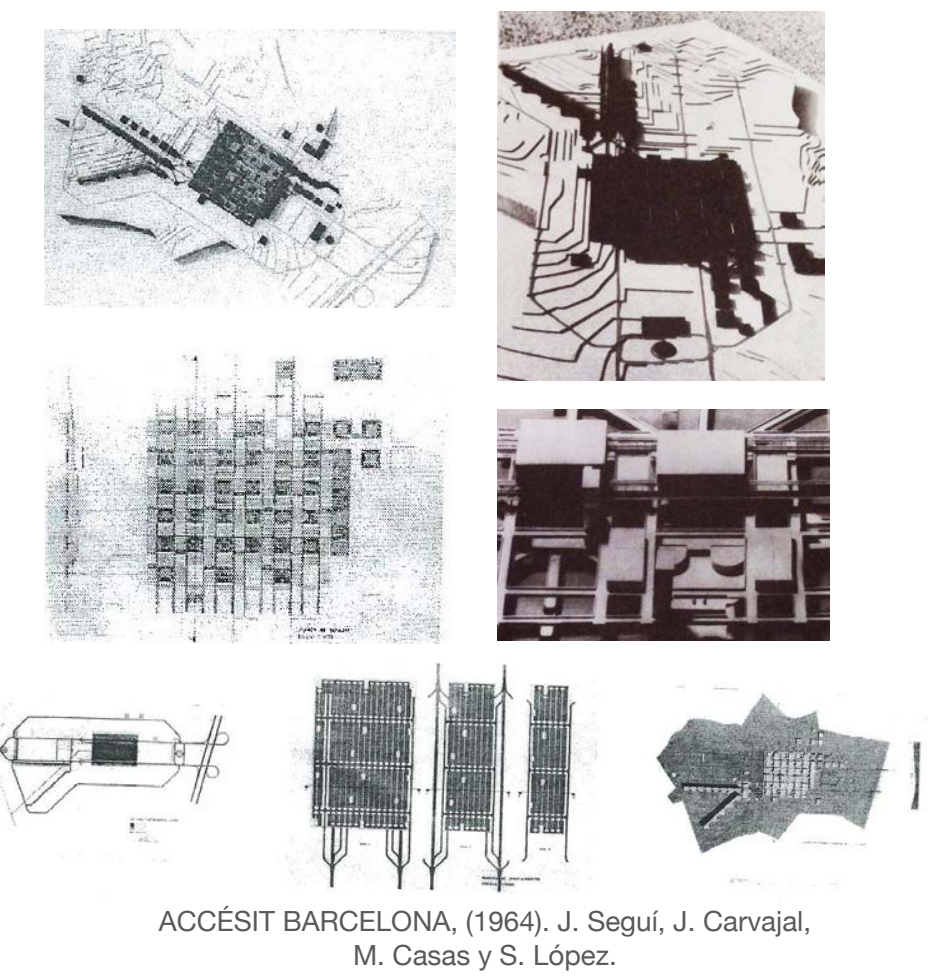

2 Fullaondo, "Javier Seguí (1964-1983)," 2. 
Desilusionado con los fracasos en de los concursos, en 1985 Seguí decide optar a la beca del Premio de Roma, "buscando acaso un exilio presumiblemente dorado" ${ }^{\prime 3}$, sin éxito.

\subsubsection{DIBUJAR}

Aunque el proyecto de arquitectura finalizado, listo para su ejecución, no es su mayor pasión, bien forzado por las circunstancias o por un interés propio, la forma de llegar hasta él es su campo de batalla. Seguí está convencido de que el dibujo es la herramienta fundamental del arquitecto para explorar las posibilidades de cualquier proyecto arquitectónico. Su objetivo final no es exclusivamente la comunicación con el mundo, sino la conexión con el universo interior de cada uno.

El recorrido en el dibujar en Javier Seguí atraviesa distintos momentos. Sin embargo, sólo la lectura global de la totalidad de su obra puede desvelar la esencia que busca desde siempre. Adivinar el gesto de sus huellas es dar a conocer la esencia de su descubrimiento.

A día de hoy Javier Seguí confirma que en el dibujar no hay palabras hechas. Se utiliza la tensión y la acción del cuerpo, sin sintaxis. Es una acción todavía más básica que hablar, puesto que sólo se trata de sacudir el cuerpo. Cuando se dibuja, el movimiento lleva el cuerpo directamente a reaccionar y a formar un discurso sin palabras. ${ }^{4}$

Nancy tiene un texto sobre el Placer de dibujar que habla justo del placer que causa el dejarte llevar, en paralelo a lo que dices, a otra cosa. Y sabe muy bien lo que está pasando. Pero te sientes acompañado. La sensación, ésta que te hablaba primero, de desdoblamiento... es como si fuéramos varias personas a la vez. Distintos personajes, ¿no? Puedes soltar uno, soltar otro. ${ }^{5}$

Dibujar es "una de esas formas de ir dejando huellas. Es una especie de danza", ${ }^{6}$ un baile que se descubre bailando y que se encuentra en el discurrir de la acción; un baile en el que la mano va adquiriendo conocimiento y emoción, una felicidad que se encuentra no en la estación a la que se llega, sino en el viaje que se hace.

3 Fullaondo, "Javier Seguí (1964-1983)," 4

${ }^{4}$ Javier Seguí, Sobre dibujar y proyectar (Buenos Aires: Nobuko, 2012).

Seguí, 21 de enero, 2014.

Javier Seguí, entrevistado por Maria Brito, 4 de marzo, 2014. 
El arte no puede ser un fin en sí mismo, sino el camino (como la religión) que después tiene que ser, a su vez, sacrificado y abandonado. El artista es así un mostrador de la realidad oculta, pero una vez el artista ha desocultado la realidad debe desocultar su propio arte, de lo contrario nos hallaríamos en una nueva forma de idolatría. ${ }^{7}$

Mientras dibuja no piensa, pero el dibujo le ayuda a pensar. Su mano se desliza sobre el papel y su cuerpo se acomoda a su blanca superficie. Con su ritmo, muchas veces desacompasado, mira con asombro cómo van apareciendo huellas, extrañas densidades opacas, espesas, que persiguen nuevas configuraciones. Con este dibujo espontáneo, las palabras flotan en narraciones que se van perdiendo en los vacíos que va guardando.

Siguiendo a Emmanuel Levinas y Giorgio Agamben, lo que hace no lo encuentra fuera de sí, sino haciendo.

Para Javier Seguí, dibujar es dejar marcas del movimiento en un soporte. Sus dibujos son "acontecimientos cristalizados irrepetibles de un hacer henchido de fantasías remotas retenidas en los músculos". ${ }^{8}$

Tú no tienes una visión previa tuya antes de la acción. Tienes una visión previa tuya relativa antes de la acción. Después de la acción, en función de lo que haya pasado, tienes otra visión tuya y tienes otra visión de lo que te rodea. Realmente el aprendizaje humano se hace a través de las acciones. Y las acciones te van modificando todo. Como la acción está basada realmente en la pasión, en la emoción y en el sentimiento, de alguna manera, y en la imaginación que los arrastra, resulta que está todo ligado. ${ }^{9}$

Dibujar es dejar que el cuerpo fluya en busca de esas imágenes interiores ocultas en el imaginario. Por ello resulta imperativo entenderlo como pista de lo arquitectónico, como nido de las imágenes codificadas que han de salir volando al papel. El dibujo se convierte, de este modo, en la materialización de lo imaginario; y la imaginación, en el motor que lo acciona.

La imaginación es la herramienta que genera y gestiona las imágenes desencadenantes de cualquier dibujo, coincida la imagen con la realidad o no. Dibujar significa configurar y ordenar con-

\footnotetext{
7 Jorge Oteiza, Quousque Tandem...! Ensayo de interpretación estética del alma vasca., trad. Pello Zabaleta Kortaberria, Amador Vega y Jon Echevarria Plazoala ed. (San Sebastian: Fundación Museo Jorge Oteiza. , 2007), 40.

8 Javier Seguí, "Encuentros 2008-2010," (Madrid: Instituto Juan Herrera de la Escuela de Arquitectura de Madrid, 2003), 16.

9 Javier Seguí, entrevistado por Maria Brito, 16 de septiembre, 2014, Grabación.
} 
secutivamente esa imaginación y las huellas que va dejando de su tanteo.

Por este motivo, los esbozos iniciales son el germen del proyecto, el reflejo del impulso instantáneo, del arrebato imaginario sobre el soporte. ${ }^{10}$

El lenguaje artístico trata de revelar nuestra conexión con el mundo, es el esfuerzo en la búsqueda de la conexión consciente. El dibujo permite pensar con imágenes. La imagen es hija de la imaginación, por eso el dibujo es el lenguaje de la imaginación. El dibujo sustenta los procesos de revelación y ocultación de la forma. ${ }^{11}$

El dibujo es el conductor del pensamiento gráfico que acompaña sus inquietudes y descodifica sus intenciones, significado que coincide con el de la RAE:

(Del fr. ant. deboissier).

1. tr. Delinear en una superficie, y sombrear imitando la figura de un cuerpo. U. t. c. prnl.

2. tr. Describir con propiedad una pasión del ánimo o algo inanimado.

3. prnl. Dicho de lo que estaba callado u oculto: Indicarse o revelarse. ${ }^{12}$

Dibujar no es sólo describir, sino desvelar algo que está oculto. No es un simple utensilio de representación, sino la interpretación sintética de lo que aparentemente no se puede percibir. En 1996 Javier Seguí afirma:

Dibujar designa delinear (configurar) en una superficie "imitando" la figura de un cuerpo; describir con propiedad una pasión del ánimo o una cosa inanimada (sic). Por dibujo se entiende el arte que enseña a dibujar; delineación, figura o imagen ejecutada en claro y oscuro, que toma nombre del material con que se hace; etc. (sic). La única matización que habría que hacer es la consideración de la "imitación" no como un acto reflejo en la ejecución, sino como un tanteo inventivo que funda la figura que luego se reconoce en el cuerpo natural. ${ }^{13}$

El dibujo es un descubrimiento interior plasmado en el exterior.

\footnotetext{
10 Javier Seguí, "Para una poetica del dibujo," Ega 2 (1994): 63.

11 Raposo, "Recopilación, estructuración y análisis de los documentos básicos manejados y elaborados en la cátedra de Análisis de Formas Arquitectónicas de la E.T.S.A.M a partir de los años 70. Aplicación a una nueva pedagogía."

12 Real Academia Española, "Dibujar," 20 de Marzo de 2015: http://lema.rae.es/drae/?val=dibujar.

13 Javier Seguí, "Glosario de términos (15-04-96)," (Madrid: Instituto Juan Herrera de la Escuela de Arquitectura de Madrid, 1996).
} 
Es la huella que queda después de la emoción. Una especie de desgarramiento interno que intenta acompañar la avidez de un hacer intuitivo sin que pretenda ser un acto de reflexión madurada.

\begin{abstract}
Suele resultar escandaloso en nuestros ámbitos docentes universitarios (arquitectónicos, claro) primar la acción sobre el pensamiento, como si esta osadía viniera a proclamar que no tiene sentido la reflexión. Indicar, con Goethe, que en principio fue la acción o, con Nietzsche, que primero es escribir y luego filosofar, o, con Bachelard, que primero es llenar la página para después poder pensar $\mathrm{y}$, con Foucault, que primero es hablar y luego pensar $\mathrm{o}$, con $\mathrm{H}$. Arendt, que cuando se hace no se piensa y cuando se piensa no se hace, suele provocar un inmediato rechazo, acompañado por diversas apologías de las virtudes de los actos gobernados, acompañados y sometidos, por el pensamiento. ${ }^{14}$
\end{abstract}

Dibujar siempre está en el horizonte de Javier Seguí, no sólo de cara a la enseñanza, sino también como instrumento de esparcimiento personal. En 1965-1966 tiene, incluso, su propia academia de dibujo, donde prepara alumnos para entrar en la escuela. El centro, según cuenta, está en el mismo edificio del estudio de arquitectura que comparte con sus socios, Manuel de las Casas y Santiago López, y le sirve para "sacar algún dinero" en los años en que empieza su carrera profesional.

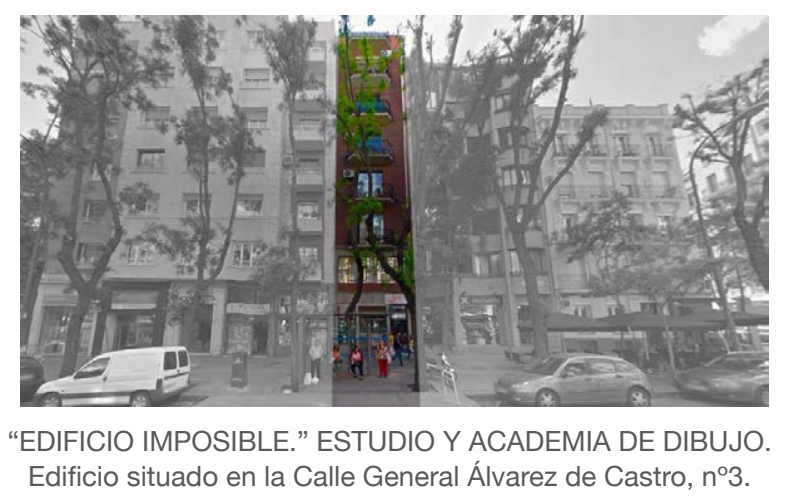

El estudio de arquitectura y la academia de dibujo se encuentran en un "edificio imposible" de cuatro metros de fachada, con muchas alturas y un patio interior. En este edificio, propiedad de su suegro, sólo la planta baja está ocupada por un almacén. El resto de los pisos están vacíos. Éste es el motivo de que instalara allí su primera sede profesional: no tener que pagar alquiler. El poco dinero que gana basta para pagar los gastos que genera.

14 Javier Seguí, Dibujar, proyectar (VI) - Escritos diversos (Madrid: Instituto Juan de Herrera de la Escuela Técnica Superior de Arquitectura de Madrid, 2004), 15. 
Se ve obligado a abandonar la academia de dibujo cuando gana la cátedra, pues es incompatible con dicho puesto.

Analizar la obra gráfica de Javier Seguí significa descifrar la unidad de su conjunto. Los distintos elementos no pretenden significar nada por separado, sino poner de manifiesto la relación existente entre ellos. Ya Le Corbusier ve en sus dibujos la clave de toda su obra: "Yo... dibujo desde siempre... cada día de mi vida ha sido en parte dedicado al dibujo. Jamás he cesado de dibujar y de pintar buscando, donde pudiera encontrarlos, los secretos de la forma. No hay que ir más allá para encontrar la clave de mis trabajos y de mis investigaciones."15

En 1966, se inaugura el Centro de Cálculo de la Universidad de Madrid (C.C.U.M), y con él, el "arte cibernético" en España. El C.C.U.M, (actual Universidad Computense de Madrid), es un proyecto pionero en España que, a semejanza de lo que se viene haciendo por toda Europa, fomenta el uso del ordenador en el proceso creativo. El Centro está asociado a la multinacional International Business Machines (IBM), que dona un ordenador IBM 7090 -uno de los más potentes del mundo en ese momento- y un IBM 1401. Dadas las dimensiones de estos equipos, la Universidad se ve obligada a construir un edificio sólo para albergarlos.

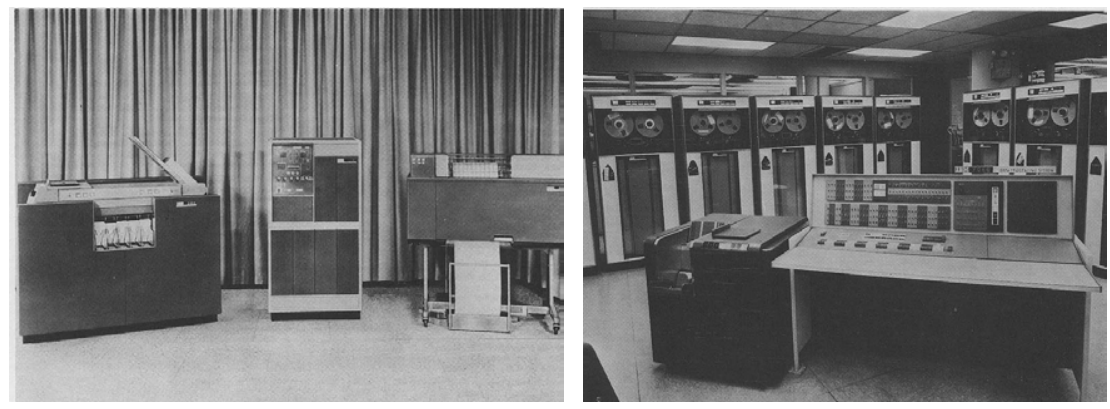

IBM 1401 y IBM 7090. Ordenadores donados por IBM al C.C.U.M. El IBM 7090, que ocupa toda una sala, es el mismo modelo que años antes sirviera para hacer los cálculos destinados a enviar el cohete espacial Saturno a la Luna.

El matemático Florentino Briones Martínez, que forma parte de la European Nuclear Energy Agency (ENEA), es nombrado director del Centro. En el discurso formal de inauguración, pronunciado por el entonces rector de la Universidad, José Botella Llusiá, se abordan los objetivos y las expectativas generadas en torno a esta nueva herramienta electrónica y sus capacidades, inexploradas hasta entonces. 
La función específica del Centro es la utilización de las nuevas técnicas de cálculo automático en la investigación y en la enseñanza y su impulsión en el ámbito nacional. (...) Para hacer más eficaz este servicio, el Centro de Cálculo organiza además cursos para la preparación del personal en la redacción de programas y en el análisis de sistemas, ofrece asesoramiento durante el análisis de los problemas y la confección de los programas concretos, y acoge en su seno toda iniciativa de estudio, personal o de grupo, de problemas contenidos en la amplia gama a los que un ordenador electrónico se puede dedicar. ${ }^{16}$

La máquina llega al ambito humano, y con ella el tratamiento masivo de información. Estos ordenadores, sin embargo, no se instalan para desarrollar funciones administrativas, sino para generar manifestaciones artísticas, ya sean piezas musicales, plásticas o arquitectónicas. Con la introducción del ordenador en el proceso creativo, se inicia una nueva forma de producción artistica, de la que Javier Seguí se sirve y beneficia en su proceso creativo. ${ }^{17}$

La utilización gráfica del ordenador nació para diagramar fórmulas matemáticas y para ilustrar proyectivamente objetos ideales. Esta posibilidad de esquematización gráfica es la fuerza animadora de muchos de los trabajos acometidos. Las imágenes diagramadas trascienden el nivel de la ilustración cuando son considerados bajo una luz intelectual. ${ }^{18}$

Además del trabajo práctico creativo, empiezan a organizarse, casi simultáneamente, los seminarios que serán un referente cultural en España.

No sé cómo se pusieron en marcha seminarios, y yo iba a todos, porque me interesaban todos, aunque estuviera más involucrado o tuviera más responsabilidad en el de arquitectura. (...) En todos los seminarios estábamos hablando de lo mismo: como algoritmizar procesos (...) Me sentía formar parte de un colectivo interesado que generaba energía. Lo más importante era la transmisión de información, jhe leído un libro!, y uno iba al libro que había leído el otro. Ese clima era el que a mí me parecía absolutamente fantástico. (...) Ahí no había personajes ni protagonistas. (...) El conjunto lo que

\footnotetext{
16 Aramis E. López Juan, "El centro de cálculo de la Universidad de Madrid. Creatividad y tecnología en la Universidad Española de los años sesenta.," artnodes. Revista de Arte, Ciencia y Tecnologia n ${ }^{\circ} 13$ (2013): 27.

17 E. López Juan, "El centro de cálculo de la Universidad de Madrid. Creatividad y tecnología en la Universidad Española de los años sesenta": 27.

18 Enrique Castaños Alés, Los orígenes del arte cibernético en España : El seminario de generación automática de formas plásticas del Centro de Cálculo de la Universidad de Madrid : (1968-1973) (Alicante: Biblioteca Virtual Miguel de Cervantes, 2000), 262.
} 
fabricaba era esa especie de buen ambiente que nos hacía ir con alegría todos los días allí a participar de las cosas que había en el Centro de Cálculo de la Universidad de Madrid. ${ }^{19}$

Estos seminarios resultan decisivos para que Javier Seguí entienda cómo debe ser el proceso de enseñanza. Mientras está en el centro, tiene la oportunidad de conocer a intelectuales como Abraham Moles, Max Bense, Negroponte, Eusebio Sempere, Luis de Pablo, Juan Navarro Baldeweg o Víctor Sánchez Zabala.

Javier Seguí y Ana Buenaventura comienzan su investigación traduciendo diseños arquitectónicos en formas circulares:

A partir de una matriz circular arbitraria, eliminaron elementos al azar hasta conseguir composiciones con un contenido tensional satisfactorio. (...) Una nueva fase en la producción de ambos apareció a partir del conocimiento que tuvieron de unos dibujos realizados por estudiantes de matemáticas que pretendían "reproducir con la calculadora el crecimiento de una colonia de microorganismos". El esquematismo de estos dibujos les pareció idóneo para ser usado en sus investigaciones, surgiendo de ahí una colaboración a partir de la cual crearon un programa con el que trabajaron en 1973. ${ }^{20}$

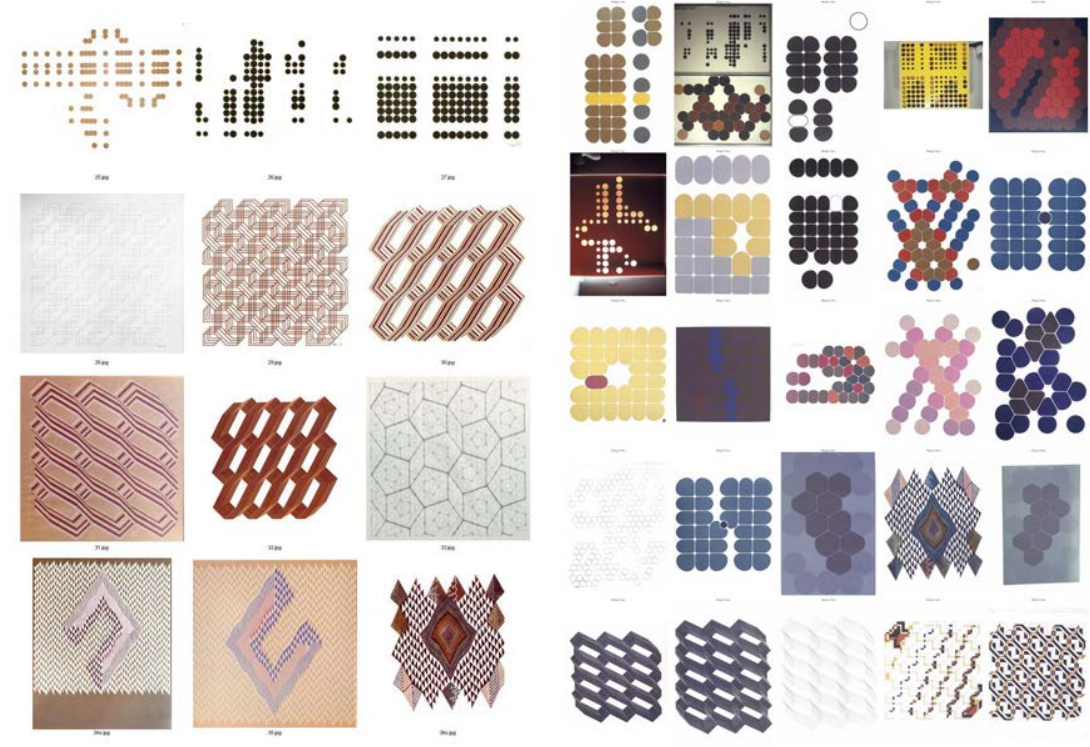

DIBUJOS REALIZADOS POR ORDENADOR. C.C.U.M., (1968-1971). Javier Seguí y Ana Buenaventura.

Resulta evidente la precoz inquietud de Seguí por buscar en el

\footnotetext{
19 Juan, "El centro de cálculo de la Universidad de Madrid. Creatividad y tecnología en la Universidad Española de los años sesenta."

20 Castaños Alés, Los orígenes del arte cibernético en España : El seminario de generación automática de formas plásticas del Centro de Cálculo de la Universidad de Madrid : (1968-1973), 199.
} 
dibujo significados arquitectónicos, empezando a "simular con ordenador qué operaciones hay que hacer para fabricar el diseño de un edificio". ${ }^{21}$ Su investigación parte, precisamente, de la necesidad de demostrar que detrás del dibujo hay otra materia que es fundamental a la hora de proyectar.

Una forma puede pensarse como agregación ordenada de otras. Considerado un orden uniforme e isomórfico, la forma es la alteración de ese orden primario por mediación de otro orden superior. El control del proceso se logra definiendo en cada caso el intervalo de universo y magnitud de los subconjuntos a eliminar. ${ }^{22}$
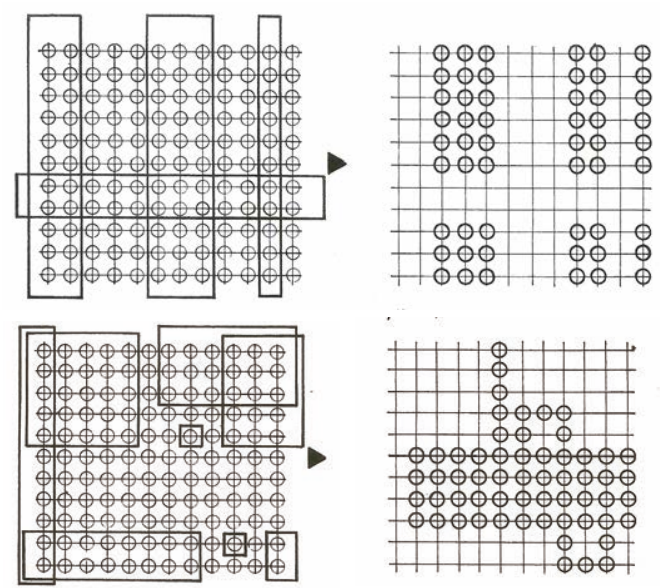

DESCOMPOSICIÓN DE FORMAS DE CULTURA, (1968-1971). Javier Seguí y Ana Buenaventura. Arriba se eliminan seis columnas y dos filas. Abajo se suprimen seis zonas y dos puntos.

Cuando empieza a dibujar sirviéndose de una base geométrica, abandona definitivamente la representación: "Ya me había salido de la representación y ya estaba en otro mundo. En ese ínterin estaba claro que hacer las cosas es encontrar sistemas, organizaciones sistemáticas, para que operando sobre ellas aparezcan posibles soluciones". ${ }^{23}$

En 1973-1974 estos seminarios mueren, suscitando una crítica mordaz por parte de Javier Seguí y Ana Buenaventura, que coinciden en que la magia de las inquietudes que se habían despertado en un principio, al final no son más que una forma pretenciosa de proyectar obras sofisticadas carentes de relevancia conceptual.

\footnotetext{
21 Javier Seguí, entrevistado por Maria Brito, 5 de mayo, 2014, Grabación.

22 Santiago Amón, "Actividad, pensamiento y estructura en la obra de Javier Segui y Ana Buenaventura," 10 de agosto de 2015: http://www.javierseguidelariva.com.

23 Seguí, 5 de mayo, 2014.
} 
Después de esta primera hornada gráfica en la que empieza a tantear nuevas formas de hacer, cabe destacar otro grupo, que titula Gotas de soledad (1965-1977) y que surge con más ímpetu años después de ganar la cátedra. Los dibujos Gotas de soledad hacen referencia a un momento particular de su vida en el que empieza a realizar los cambios que considera oportunos. En esos momentos experimenta una soledad absoluta al ver que nadie entiende sus propuestas; un sentimiento que, quizás por una dificultad en compartir sus inquietudes y proyectos con los demás, cinco décadas después, aún padece. Estos dibujos se realizan con herramientas académicas ortodoxas, como lápices, bolígrafos, acuarelas y rotuladores de colores.
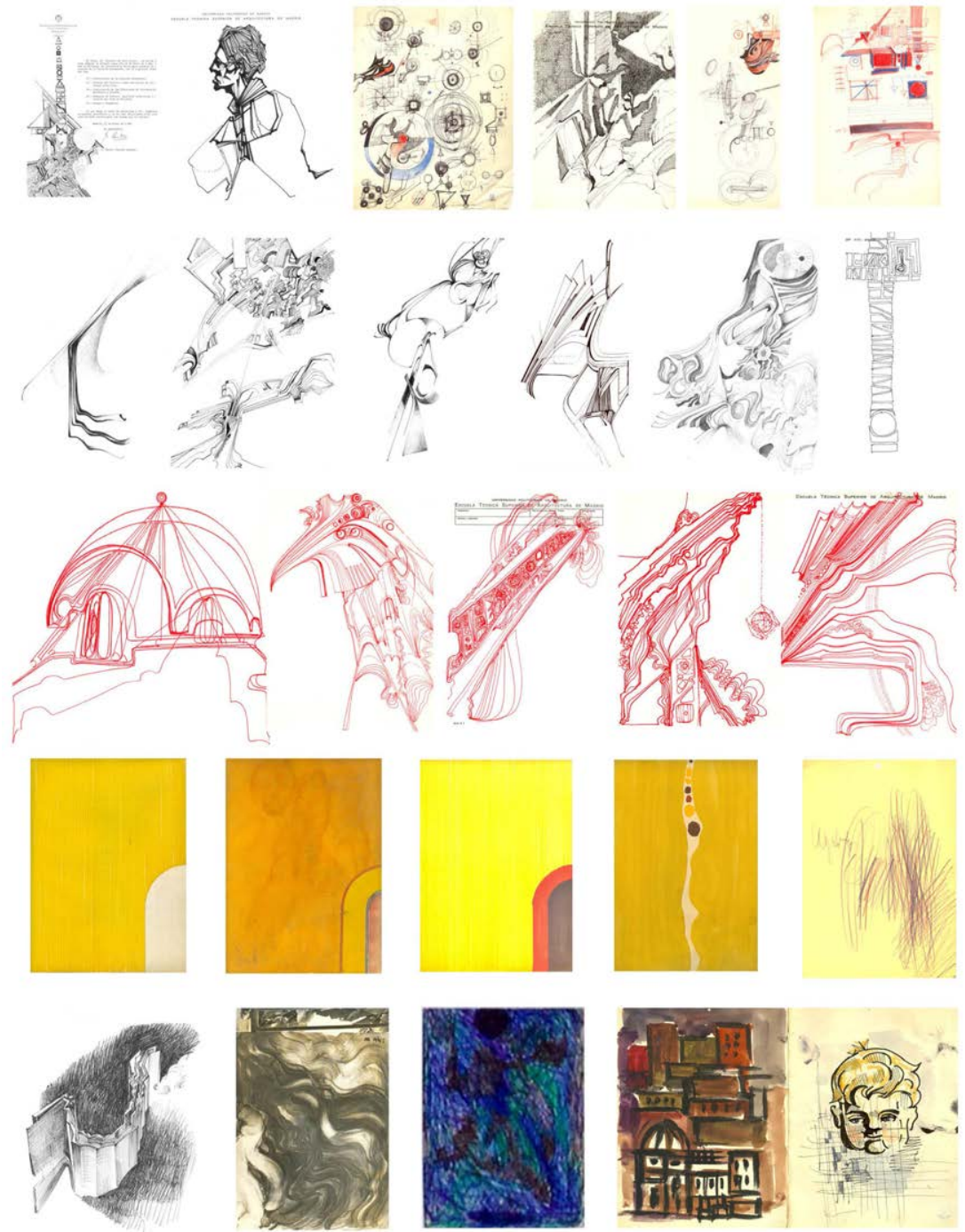

GOTAS DE SOLEDAD, (1965-1977). Javier Seguí.

Su ejecución marca el arranque de un proceso que plantea el dibujar no como representación final, sino como origen del pro- 
yecto arquitectónico. A pesar de su insistente huida de la representación, van apareciendo tímidamente algunos retratos; Seguí confiesa que con ellos no quiere demostrar nada, tan sólo descansar de esa búsqueda obstinada. Para él la representación es algo mecánico, que no puede controlar. Confiesa que estos dibujos le salen "así que se descuidaba", y que su mano autónoma lo lleva a retratar lo que tiene delante: su familia, objetos o paisajes. Como él mismo dice, la "no-representación" es un esfuerzo para no hacer "representación".
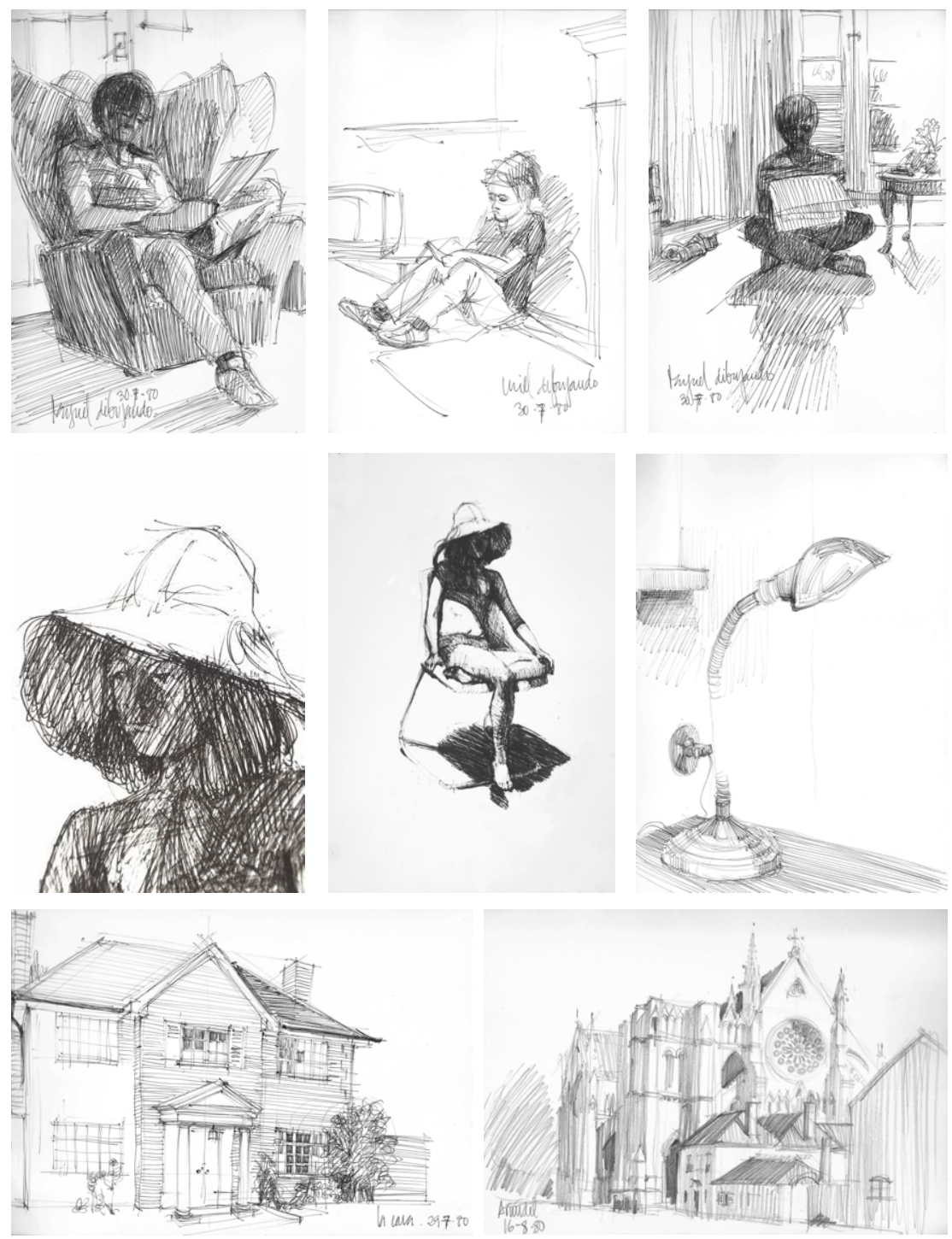

CUADERNO MARRÓN CROQUIS, (1980). Javier Seguí. Dibujos de sus hijos, su esposa y casas.

Después de sus momentos de soledad, Javier Seguí empieza a inventar estrategias para intentar cambiar la visión de sus colegas y su falta de comprensión de cara a los cambios que propone. A raíz de esta determinación decide enseñar dibujos que 
"salieran de su expresión normal", como los que hace en Arte y conocimiento, que intentan demostrar que "los dibujos no se contemplan para sentir placer, sino para que sean interpretados" y si no es así, el dibujo no cumple su misión.

En esta época de cambios uno tiene que practicar aquello que defiende $y$, por este motivo, decide enseñar sus dibujos como una estrategia para justificar lo que plantea hacer en la cátedra. Realiza dibujos y hace exposiciones para compartir con sus colegas las experiencias: dibujos que se salen de lo corriente, con la intención de que en algún momento a ellos le parezcan normales.

Son una especie de intentos de realizar dibujos pensando en los profesores, en la historia del dibujo y en todo el proceso de enseñanza del proyectar. Lo que trata de hacer es una suerte de repaso y recreación de todos los movimientos artísticos del siglo $\mathrm{XX}$; intentar recopilar la temática fundamental de lo que se está haciendo, que tiene que ver con la geometría.

Estos ejercicios gráficos, realizados mayoritariamente con pluma, no sólo los practica, subvierte y propone como ejercicio, sino que además los traduce en palabras, acción fundamental a la hora de contextualizar y fundamentar sus significados.

Con el objetivo de dar forma a sus pensamientos, Seguí inicia una serie de dibujos que tienen por finalidad mostrar el orden de su trayectoria gráfica y poner de manifiesto lo que ya por aquel entonces es, a su juicio, el germen de la arquitectura. Estos dibujos pretenden demostrar que grafiar no es representar, sino un proceso de exploración, de tanteo y de conocimiento.

Ya con Aristóteles el dibujo adquiere una dimensión cognoscitiva, y el arte deja de tener una connotación de adorno representativo para transformarse en una "tekhne" (técnica), fuente de conocimiento. El dibujo arquitectónico surge de una unión entre el conocimiento geométrico y "el dominio de una práctica (poiesis) que facilita su ejecución: la acción de dibujar."24

Al principio le salen dibujos extremos que luego van tomando forma. Su nuevo método, Seguí cuenta, está relacionado con la "interpretación o hermenéutica grafica" ${ }^{25}$, de Wilhelm Dilthey. En este sentido, Javier Seguí presenta una serie de ejercicios para desentrañar sus grafismos, a partir de los cuales nace la publicación Experiencias gráficas. Arte y conocimiento.

\footnotetext{
24 F. León Florido, "Forma y dibujo. Notas para una fundamentación filosófica del proyecto," Ega 6 (2001): 29.

25 Javier Seguí, Experiencias graficas. Arte y conocimiento. (Madrid: Fundación Universidad Empresa, 1979), 4.
} 
De ese estudio surgen tres grupos temáticos: Al primero lo titula Génesis de los arquetipos geométricos, y su intención es indagar en los "principios significadores de los trazados básicos". ${ }^{26}$ En este grupo, Javier Seguí propone una interesante interpretación de los polígonos y poliedros regulares, que más adelante servirá de base a su interpretación esotérica del tarot. Además de generar las figuras más significativas, realiza todos los trazados posibles para cada representación numérica, reflejando en cada una de ellas sus fundamentos simbólicos.

Nos dimos cuenta de que el conjunto de los cerca de 90 dibujos obtenidos era el manual práctico para el estudio de la significación de las figuras, presentado de forma gráfica, mandálica, apto para la reflexión y la meditación. ${ }^{27}$

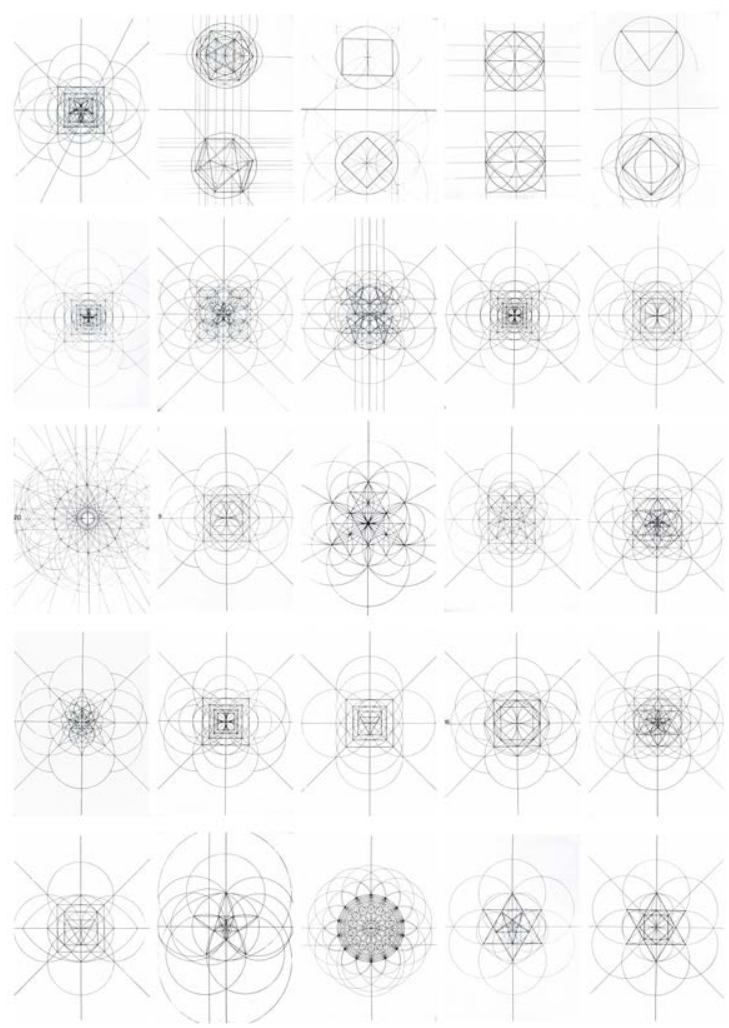

EXPERIENCIAS GRÁFICAS. ARTE Y CONOCIMIENTO: GÉNESIS DE LOS ARQUETIPOS GEOMÉTRI-

COS, (1979). Javier Seguí.

La geometría, asociada principalmente a la objetividad de la representación, no es sólo entendimiento que la analiza, sino imaginación que la construye. Kant lleva a cabo una importante síntesis de esta paradoja, justificando el traslado de la representación geométrica de un plano virtual a uno real. 
A partir de ese momento, la realidad es geométrica, no porque sus formas se nos impongan (Platón), ni porque nosotros lo hayamos decidido arbitrariamente así (Descartes), sino porque no tenemos otro modo de representar la realidad más que como geométrica, debido a la especial constitución de la razón humana, inexorablemente atada a los sentidos, pero apuntando hacia un ideal espiritual inalcanzable. ${ }^{28}$

En esta exploración de lo gráfico, Javier Seguí decide empezar por el esqueleto del dibujo arquitectónico, empleando la geometría como una herramienta desveladora de la propia imaginación.

En el segundo grupo, que denomina Una exploración del espacio, Seguí continúa su investigación y utiliza como base el análisis geométrico llevado a cabo en la primera fase. En él, Javier Seguí empieza a "explorar la esencia del grafismo"; trata de averiguar lo que desde un primer momento considera determinante en la forma de articular el pensamiento, que tiene que ver con el orden en el que van surgiendo las formas. Trazados con pluma negra, los ejercicios deben sugerir distintos espacios simbólicos, que pueden ser esquemas arquitectónicos, pero también figuras humanas.

Estos dibujos se llevan a cabo con líneas rectas o curvas, sin cruzar o cruzándose, según un "orden generativo-perceptivo". Con ellos afloran seis tipos de espacios distintos:

Los espacios germinales son el espacio de la acción que se corresponde con el primer momento del pensamiento.

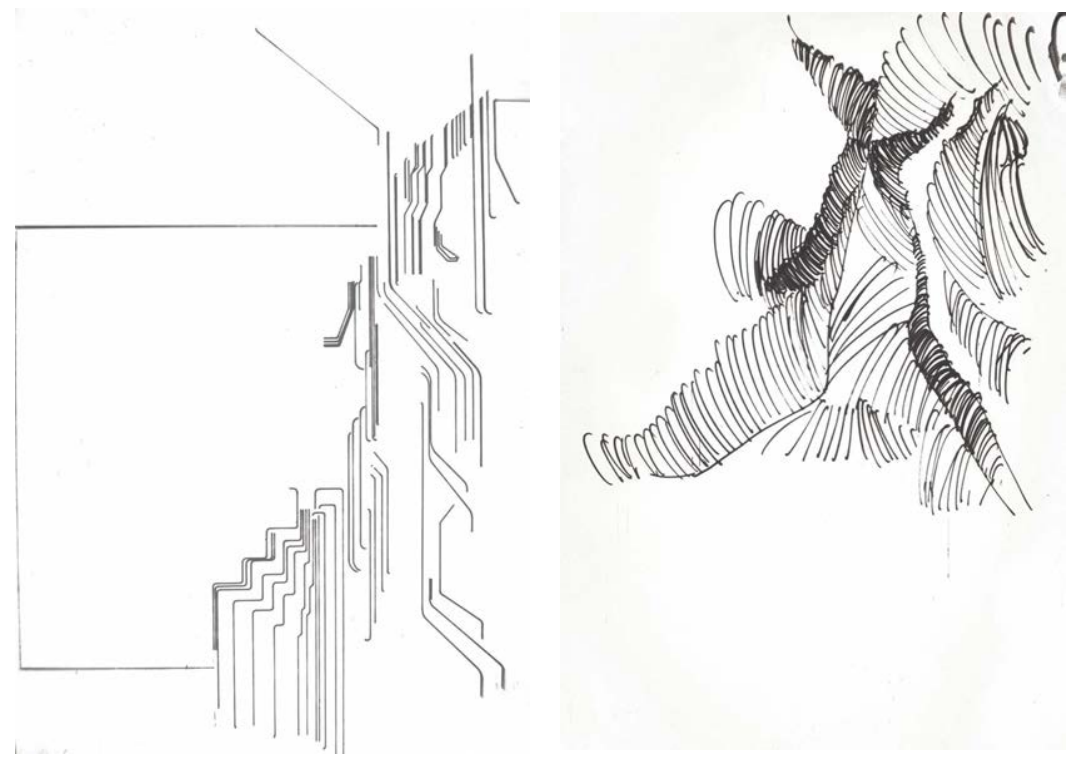


Los espacios generacionales surgen cuando el trazado añadido o sustraído supone "el desvelamiento de la organización soporte de la significación orgánica".
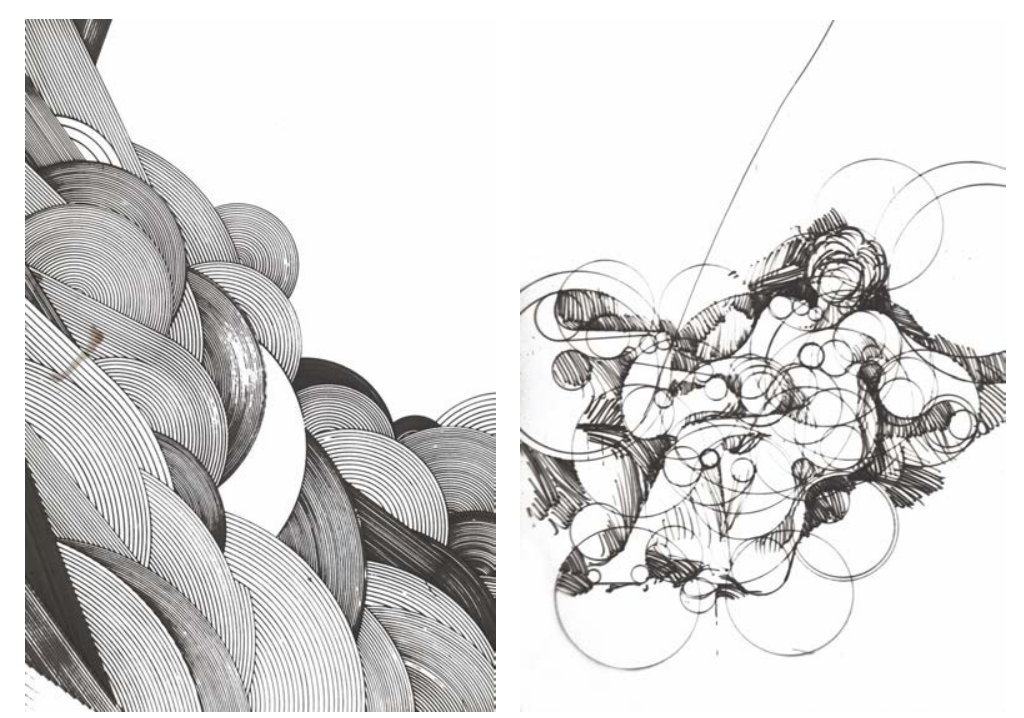

EXPERIENCIAS GRÁFICAS. ARTE Y CONOCIMIENTO: UNA EXPLORACIÓN DEL ESPACIO, (1979). Javier Seguí. Espacios generacionales.

Los espacios ilusorios, que parten de una base germinal, sugieren múltiples significaciones.

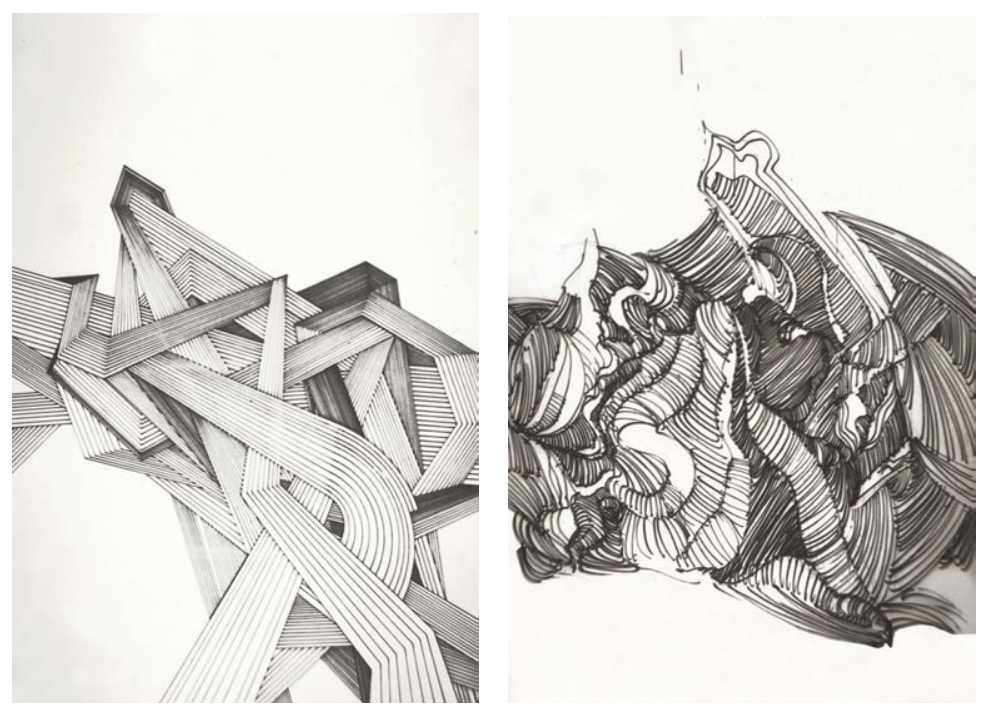

EXPERIENCIAS GRÁFICAS. ARTE Y CONOCIMIENTO: UNA EXPLORACIÓN DEL ESPACIO, (1979). Javier Seguí. Espacios ilusorios.

Los espacios formativos proporcionan un "despliegue en profundidad de diversos planos vivenciales" a través de un trazado que va creando tensiones y relaciones que pueden someterse a reflexión. 


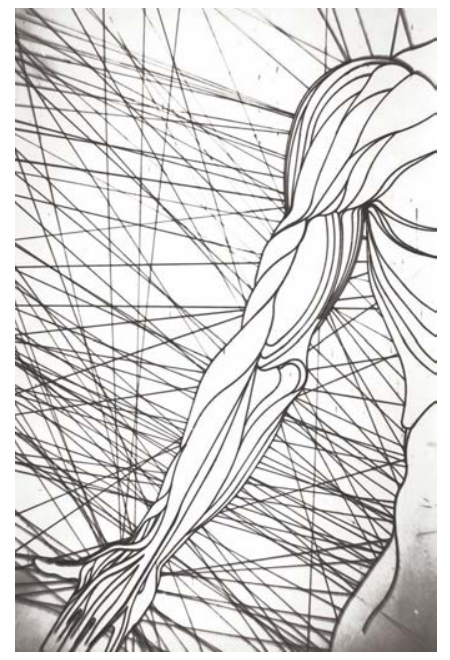

EXPERIENCIAS GRÁFICAS. ARTE Y CONOCIMIENTO: UNA EXPLORACIÓN DEL ESPACIO, (1979). Javier Seguí. Espacios formativos.

Los espacios arquetípicos son aquellos dibujos en cuyas significaciones se da un orden formal muy evidente y que, de alguna manera, componen figuras cerradas.
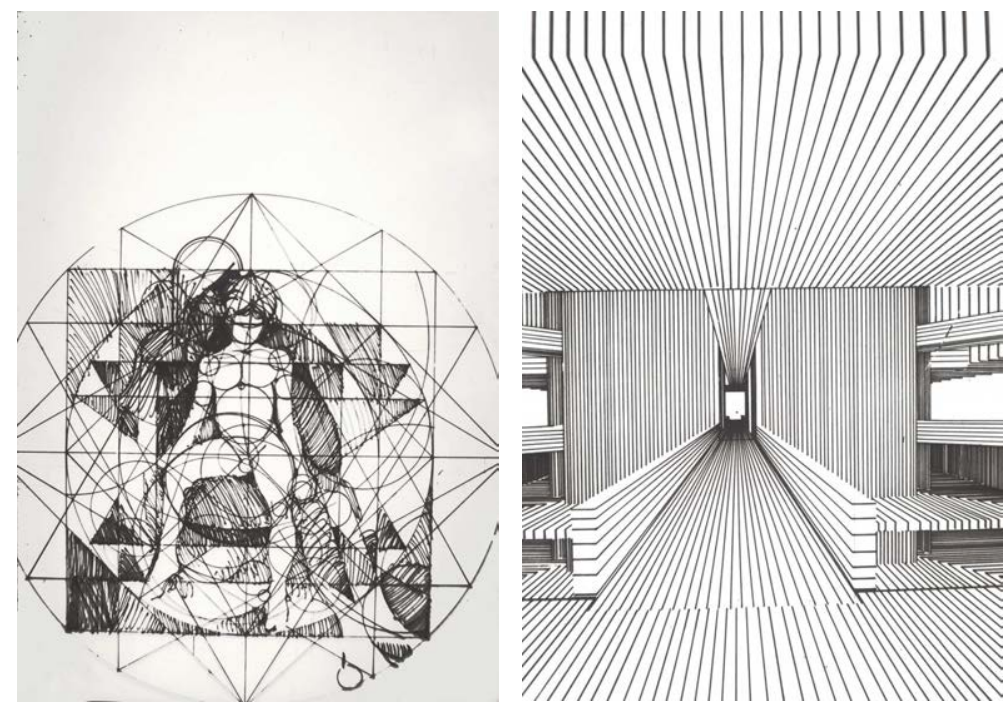

EXPERIENCIAS GRÁFICAS. ARTE Y CONOCIMIENTO: UNA EXPLORACIÓN DEL ESPACIO, (1979). Javier Seguí. Espacios arquetipo.

El último grupo hace referencia a los espacios perceptivos, que son aquéllos cuya configuración se aproxima más al modelo que el ser humano tiene del mundo. Estos espacios se resuelven por separado, pero también se fusionan y superponen, dando lugar a nuevos espacios configurativos. ${ }^{29}$ 


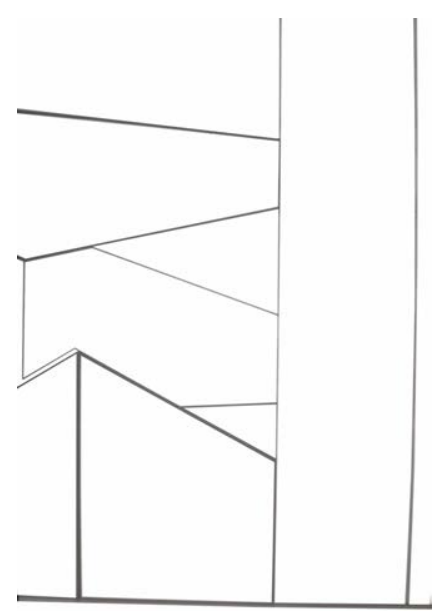

EXPERIENCIAS GRÁFICAS. ARTE Y CONOCIMIENTO: UNA EXPLORACIÓN DEL ESPACIO, (1979). Javier Seguí. Espacios perceptivos.

Por último, aparecen unos dibujos con los espacios anteriores hibridados.

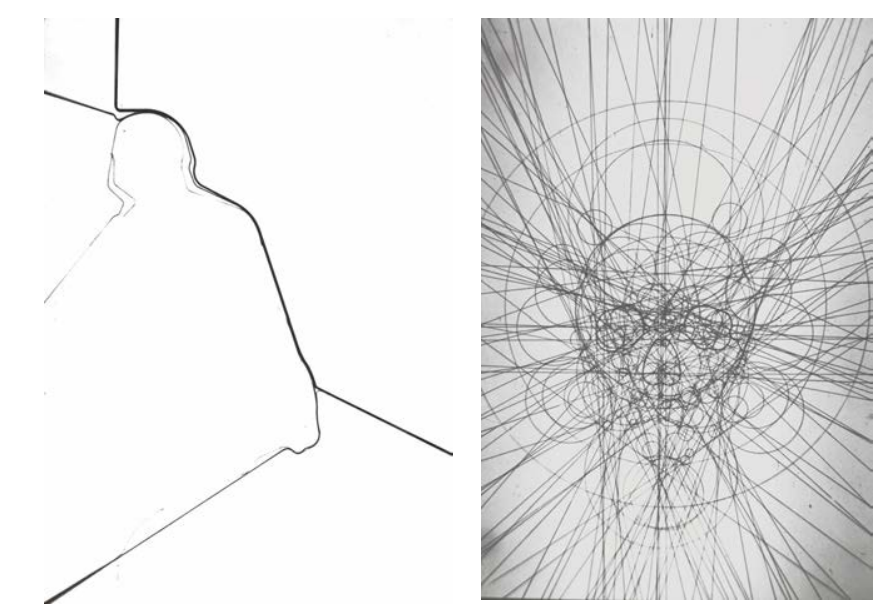

EXPERIENCIAS GRÁFICAS. ARTE Y CONOCIMIENTO: UNA EXPLORACIÓN DEL ESPACIO, (1979). Javier Seguí. Mezcla de los varios espacios.

El tercer y último grupo, titulado Una exploración del alma, intenta acercar el dibujo gráfico al alma, enarbolando la bandera del "destino y de la libertad". Su objetivo es encontrar en los ejercicios anteriores las herramientas necesarias para sacudir el alma, sirviéndose de la poesía en su génesis. Se trata de dibujos realizados en su mayor parte con lápices de colores, que responden a la vivencia, más que a la comprensión. ${ }^{30}$

Estos dibujos, que van más allá de la contemplación, pretenden agitar el pensamiento y plantear una interpretación que dé pie al debate. 
Solo, en busca de la soledad luminosa deshaciendo en repeticiones tu compañía que deseo eternamente nueva y virgen.

Contra mis ataduras que pueden ser las tuyas: si me LO dices camino sin descanso, al borde del destino en el vértigo de la nada o de la ley que ha de destruirme. Hablo y hago, pero importan poco las palabras y las acciones y reflexiones si no me permiten llegar un poco más allá. al borde del destino en el vértigo de la nada o de la ley que ha de destruirme. Bendito sea el camino de la liberación con independencia de adónde lleve. ${ }^{31}$
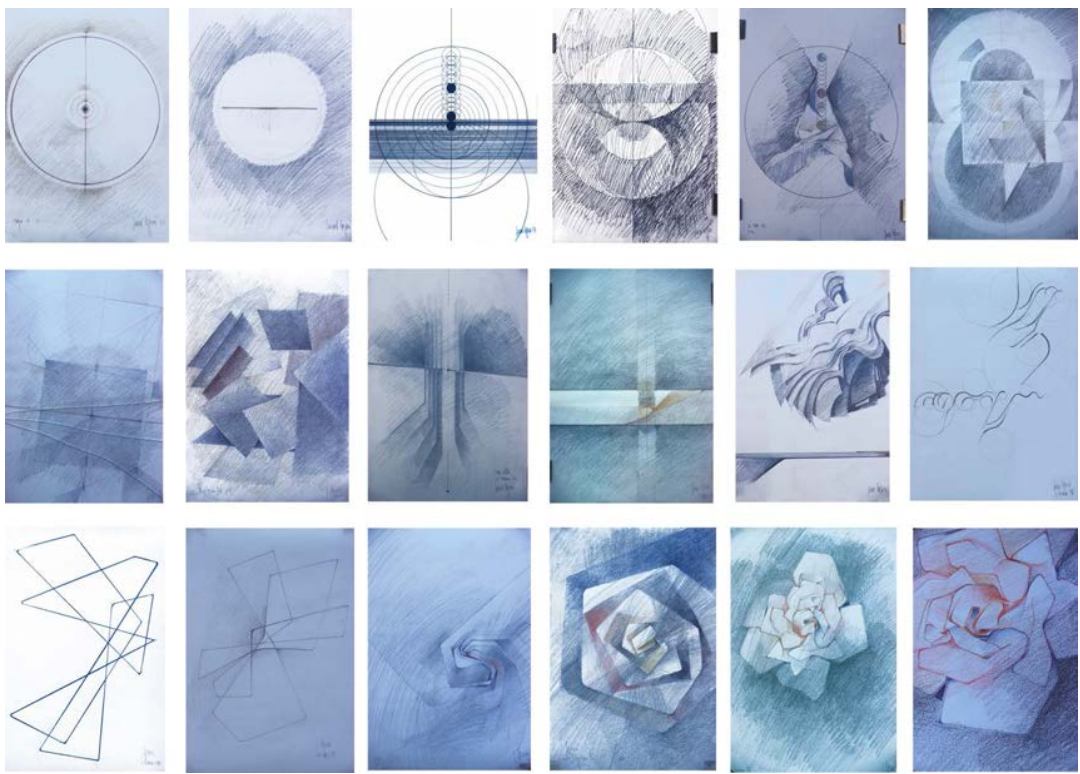

EXPERIENCIAS GRÁFICAS. ARTE Y CONOCIMIENTO: UNA EXPLORACIÓN DEL ALMA, (1979). Javier Seguí.

Estas innovaciones surgen en un momento cultural en el que parece que nadie lee nada; ni mucho menos se habla de la interpretación de los dibujos. Con la publicación de La realidad y su sombra, de Emmanuel Levinas, y El hombre sin contenido, de Giorgio Agamben, se empieza a entender al artista, que deja de mirar lo que hay fuera del arte y da prioridad a su modo de proceder. No se trata de mirar el exterior, sino de internalizar un procedimiento y sumirse uno en una especie de ascesis.

A principios de los años ochenta, y a raíz de la exposición de Maceió (Brasil), Javier Seguí propone otro grupo gráfico. Se exhiben dibujos de la Serie Maceió, que plasman magia, poder, sueños, placer y agresividad. Esta exposición reúne obras de

31 Seguí, Experiencias graficas. Arte y conocimiento, 25. 
tres épocas distintas. La primera (1972-1973) revela una inquietud post-constructiva dentro del computer art. La segunda (1976-1977) muestra una inquietud post-conceptual denominada arte formativo. La tercera (1981-1982) constituye un esfuerzo dramático en pro de la integridad moral y se puede llamar arte de supervivencia (Serie Maceió).

La serie del arte de sobrevivencia, Serie Maceió, consta de doce dibujos hechos con lápiz de color y dos en tinta nanquim. Como comenta Seguí, representan un arte defensivo, de supervivencia, pero también una crítica al entorno que acorrala. Traducen su búsqueda de la tranquilidad, una huida de la hostilidad a la que se siente sometido.
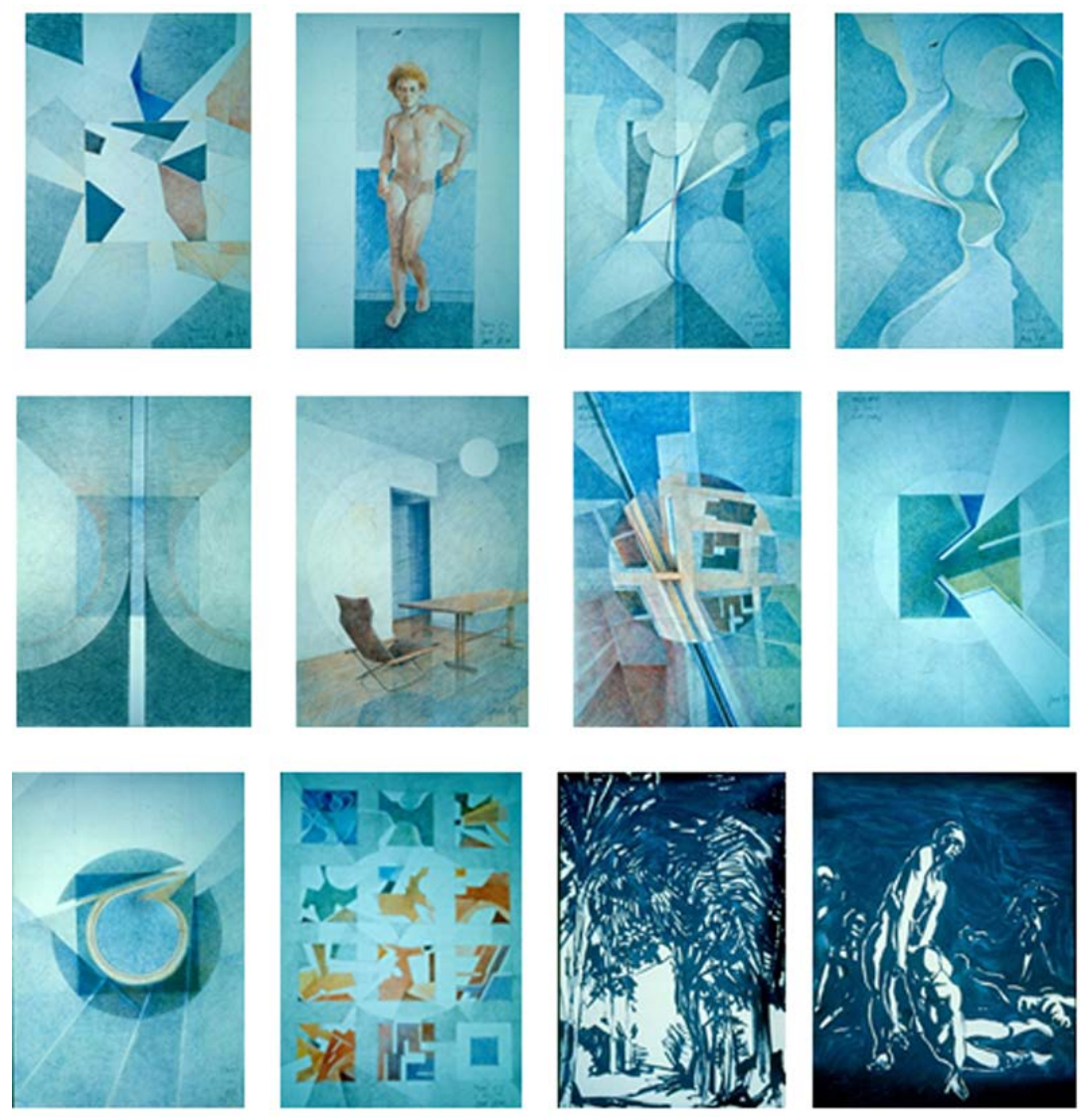

De arriba abajo y de izquierda a derecha: MACEIÓ N² -Âmbito do poder (1982); MACEIÓ Nº4 - Presença. Ámbito vital (1982); MACEIÓ N5 - Sonho de prazer e morte (1982); MACEIÓ Nº6 - Sonho liquido (1982); MACEIÓ Nº7 Sensação nocturna (1982); MACEIÓ N8 - Consciencia (1982); MACEIÓ N9 - Âmbito da magia (1982); MACEIÓ Nº10 - Insurreiçao (1982); MACEIÓ Nº11 Âmbito Cósmico, (1982); MACEIÓ №12 - Alfabeto do poder (1982), PRAIA DA AVENIDA n¹940 (1982); PRAIA DA AVENIDA n¹940 (1982) 
Seguí reconoce que entre 1964 y 1993, por exceso de trabajo, no dedica tanto tiempo a las pasiones de dibujar y escribir, pero en los últimos trece años (2002-2015), coincidiendo con la crisis en la profesión y sus últimos años como docente, vuelve a una producción masiva de dibujos a los que llama Ininterrumpido dibujar. Este momento representa un período de producción gráfica sin interrupciones: tiene tiempo para experimentar con las técnicas más variadas e, incluso, crear sus propios instrumentos de dibujo.

Hace años empecé lo que podría llamarse "una aventura indefinida en el ámbito de la expresión gráfica". Sabía que dibujar es fabricar contra moldes de la movilidad, hacer matrices espaciales aplanadas, conformadas por los movimientos liberados en los rituales ejecutorios. Sabía que esos contramoldes nacen diferentes según la cadencia y amplitud de la danza ritual. ${ }^{32}$

Consciente de que sólo el "hacer" puede cambiar el modo de pensar, decide modificar ese modo de hacer y probar otras formas de pensar. Enrique Solana coincide con Javier Seguí y reitera: "El pensamiento experimenta cambios cuando se materializa en dibujos; no es que encuentre su expresión en él; de ahí su carácter operativo, como capaz de transformar el pensamiento en curso." 33

Por este motivo decide experimentar con nuevas herramientas, nuevos formatos de hojas y, en consecuencia, nuevas formas de dibujar, que varían o se adaptan a cada necesidad de estar siempre dibujando en cualquier soporte que se encuentra y amolda a su producción.

En el caso de que el soporte sea suficientemente grande en relación a la huella, el gesto grafiado flota. Adquiriendo la apariencia de una tentativa objetual. Cuando el tamaño del soporte es equivalente al de la huella, el soporte es lo que adquiere la entidad fundamental de encuadre, que acaba siendo descompuesto y pautado por la gestualidad. ${ }^{34}$

\footnotetext{
32 Javier Seguí "Ininterrumpido dibujar. Trazos, gestos, ademanes.," ed. Fundación Coam (Madrid2004).

33 Enrique Solana, "Dibujo y proyecto; mística, emoción, razón e interpretación," Ega 6 (2001): 46.

${ }^{34}$ Javier Seguí, Dibujar, proyectar (I) - Escritos acerca del dibujar y el dibujo y del proyectar y el proyecto arquitectónico. (Madrid: Instituto Juan Herrera de la Escuela de Arquitectura de Madrid, 2003), 16
} 


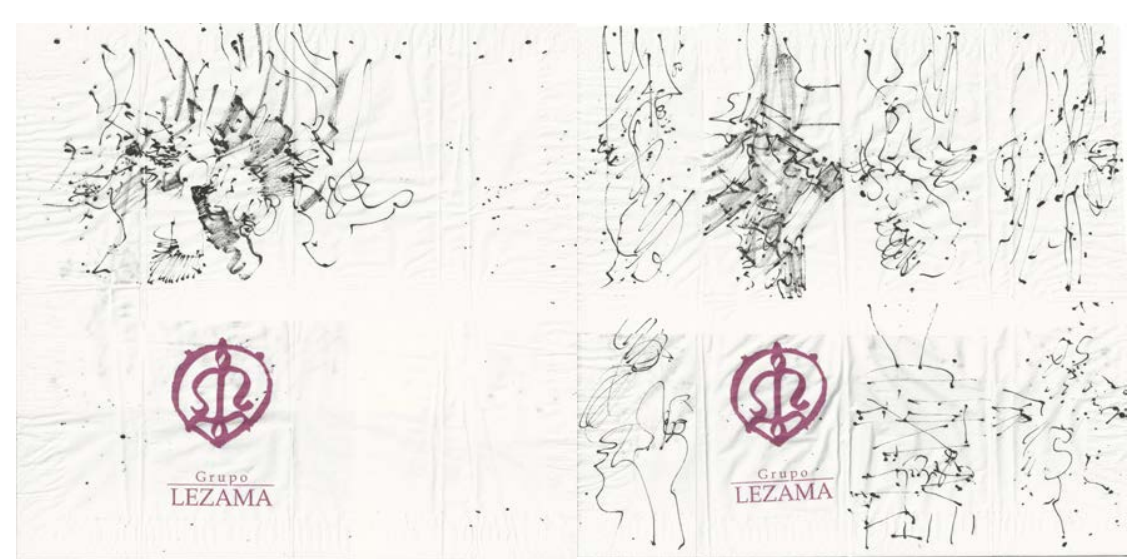

ININTERRUMPIDO DIBUJAR, (2014). Javier Seguí. Dibujos hechos en servilletas de papel.

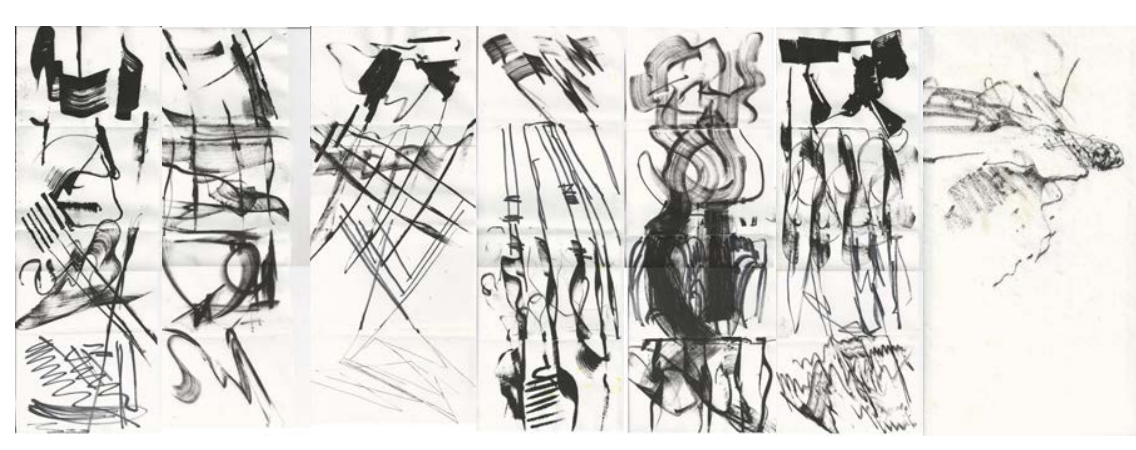

ININTERRUMPIDO DIBUJAR, (2014). Javier Seguí.

La hoja más pequeña, de aproximadamente diez centímetros de ancho, la empieza a utilizar en 2000 , cuando deja de fumar. Combate su adicción al tabaco sustituyéndola por su adicción al dibujo. Ésta es la razón por la que siempre lleva en el bolsillo un pequeño bloc de hojas para dibujar, donde hasta el momento ha habido una cajetilla de tabaco negro.

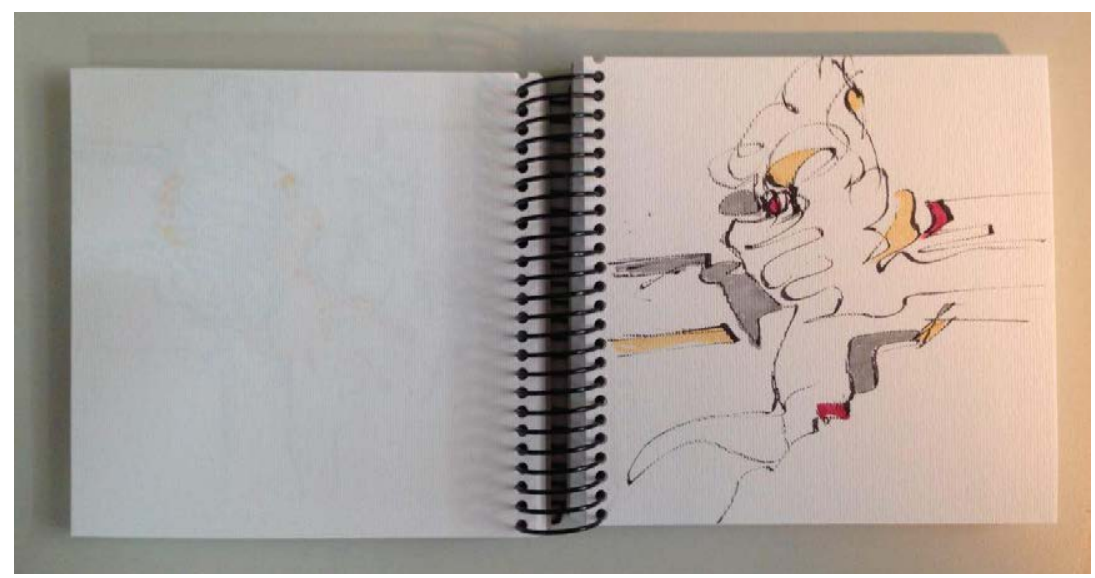

DIBUJOS ININTERRUMPIDO DIBUJAR, (2015). Javier Seguí. Dibujos realizados en pequeño formato: $10 \mathrm{~cm} \times 10 \mathrm{~cm}$. 
A semejanza de Beuys, Javier Seguí, además de su salvación, encuentra en el dibujo la suma y la síntesis de su reflexión. El deseo de ir más allá de lo convencional y expresar esa abstracción de una manera singular, le lleva a buscar constantemente nuevas herramientas operativas: disfruta como un niño cuando descubre una nueva.

En esta fase, Seguí abandona el carbón, el lápiz y los bolígrafos ortodoxos y experimenta con todo lo que va encontrando.

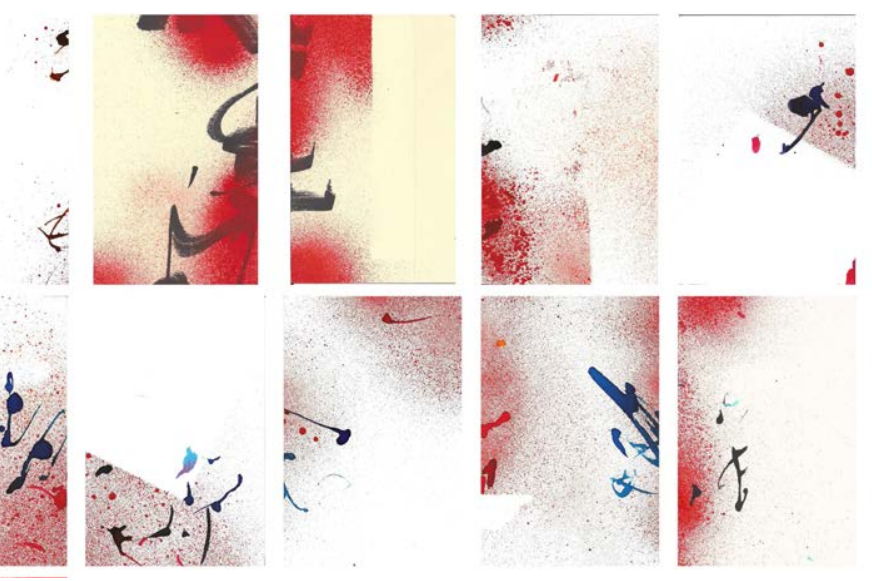

DIBUJOS ININTERRUMPIDO DIBUJAR, (2013). Javier Seguí. Dibujos realizados con spray.

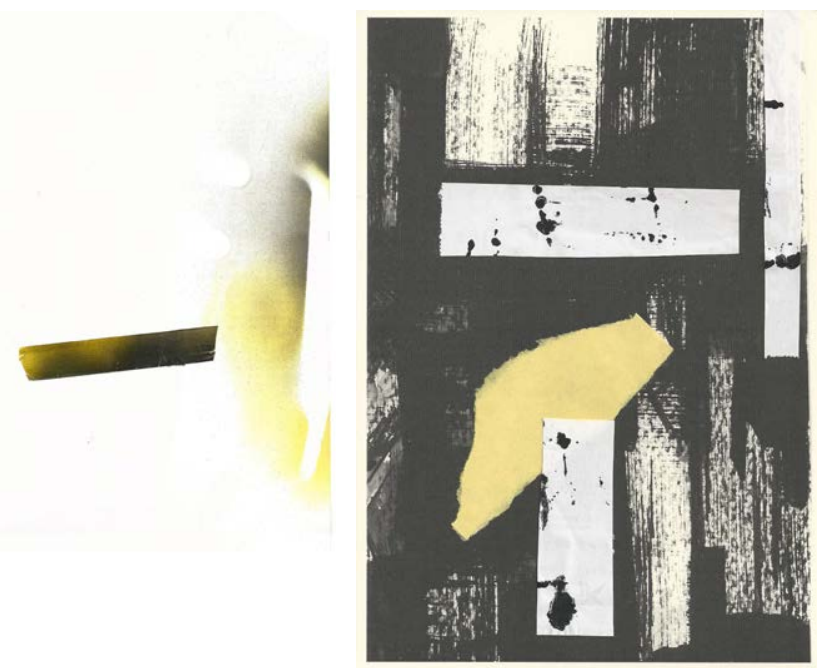

DIBUJOS ININTERRUMPIDO DIBUJAR, (2013). Javier Seguí. Dibujos con técnica mixta: collage y spray.

Dibujar siempre es un proceso operativo para Javier Seguí. En una primera fase desarrolla la técnica, la perfección y la reproducción, adoptando así la costumbre de no parar de dibujar nunca. Esta práctica va educando el gesto, la mano y el cuerpo, liberando de manera muy cómoda y eficaz sus proyectos. 
Dibujar es marcar sobre un soporte las huellas del movimiento de las manos y del cuerpo. El dibujo es el resultado de un proceder activo, movimental, guiado y controlado por el pensamiento gráfico mediado por la visión, y en todo caso es el resultado de un proceso guiado directamente por las imágenes interiores transmutadas en impulsos activos movimentales. ${ }^{35}$

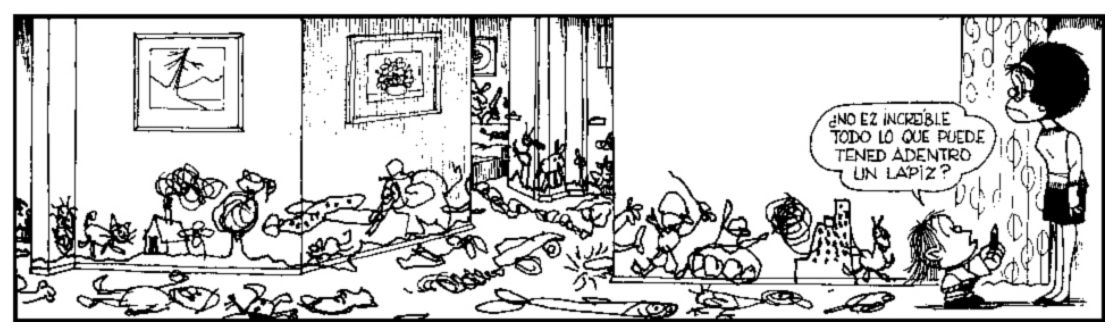

MAFALDA. Quino. Tira cómica que Javier Seguí tiene colgada en uno de los armarios de su despacho.

En sus trece años dedicados ininterrumpidamente a dibujar, se pueden apreciar algunos cambios gráficos significativos, la mayoría de los cuales se debe a su búsqueda continua de estos nuevos instrumentos. Los dibujos de la figura datan de 2004, y las herramientas empleadas son la pluma, el rotulador, el lápiz y la acuarela. La superficie de acción de estos instrumentos de impacto reducido se presta a un tipo de dibujo en el que interviene una mayor repetición de movimientos, toda vez que plasman una mancha implica tener que imprimir una gran cantidad de trazos en la superficie.

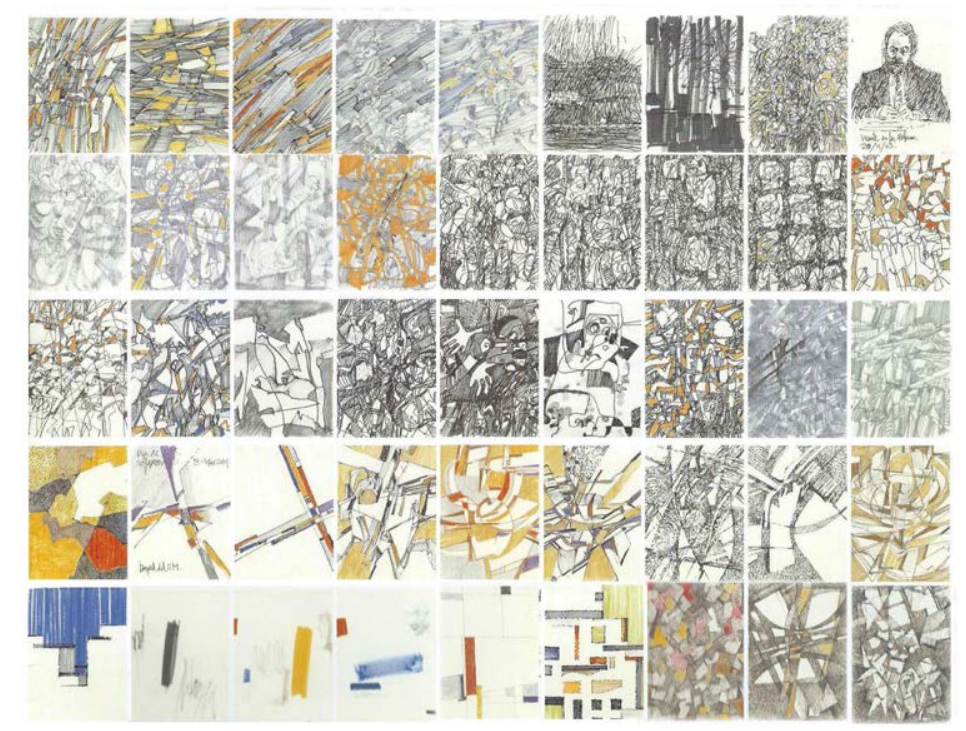

DIBUJOS ININTERRUMPIDO DIBUJAR, (2004). Javier Seguí.

35 Javier Seguí, Dibujar, proyectar (III) - Planteamientos y referencias pedagógicas (Madrid: Instituto Juan de Herrera de la Escuela Técnica Superior de Arquitectura de Madrid, 2000), 8. 
El conjunto de su obra es, por ello, una importante reflexión gráfica, un deambular por variaciones donde tantea y experimenta todo tipo de herramientas: “¿Qué es una obra de arte? Es un tema con una estructura". ${ }^{36}$

Los continuos cambios de técnica y soporte transportan al autor a otras formas de sensibilidad y, por tanto, de acometer el dibujar.

Así, por ejemplo, el cartógrafo flamenco Gerard Mercator, que a mediados del siglo XVI escribió un manual titulado Litterarum latinarum, quas Italicas, cursoriasque vocant, scribendarum Ratio. En este manual se exponen unas reglas para dibujar letras en cursiva, y en el primer capítulo se aclara la importancia no sólo del instrumento, sino también de la forma de "sostener la pluma de oca". ${ }^{37}$
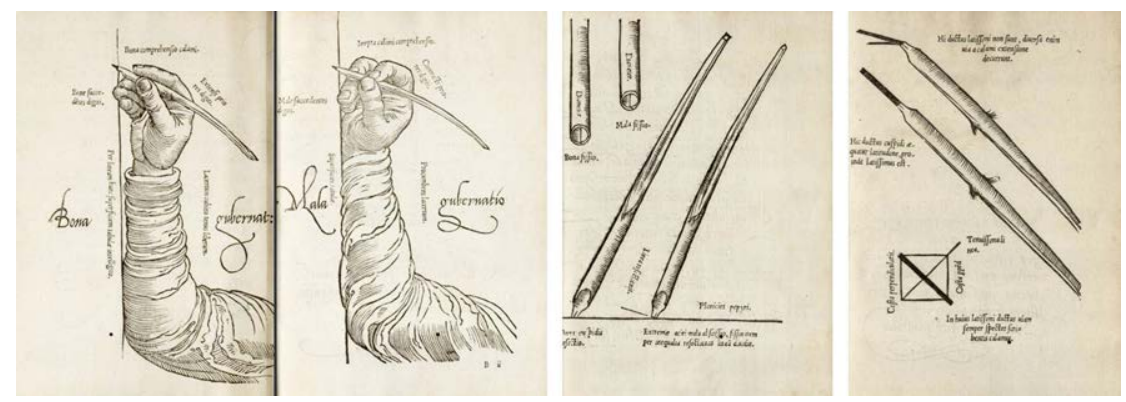

LITTERARUM LATINARUM, QUAS ITALICAS, CURSORIASQUE VOCANT, SCRIBENDARUM RATIO, (1540). Gerard Mercator.

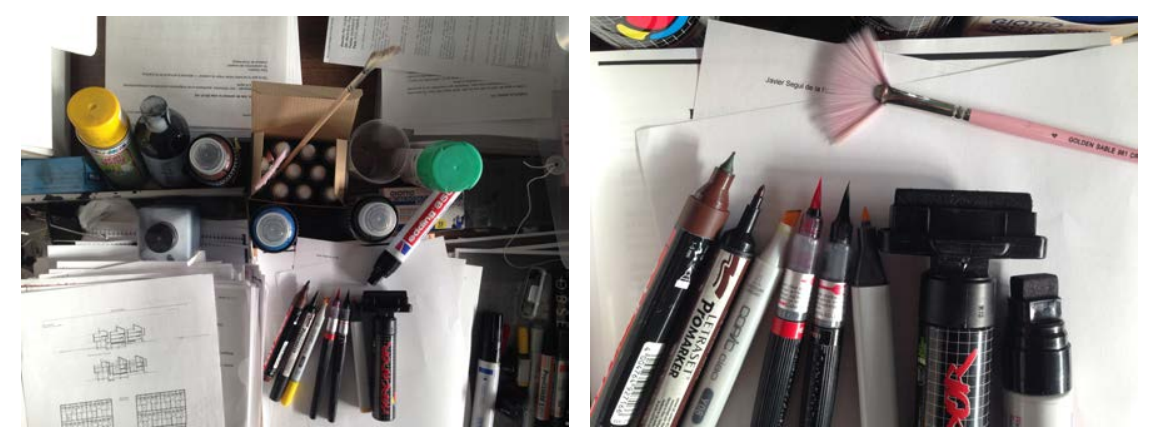

HERRAMIENTAS PARA DIBUJAR, (2015). Javier Seguí.

36 Oteiza, Quousque Tandem...! Ensayo de interpretación estética del alma vasca, 38. 37 Pilar Chías, "La caligrafía de mercator y otras singularidades de la rotulación de mapas," Ega 13 (2008): 85. 
Seguí dedica sus primeros esfuerzos a "diseñar desde la visión de los sistemas inteligentes y del dibujar catastrófico." ${ }^{38}$ Con ello, desea reivindicar un dibujar como entendimiento continuo de un proceso, donde la memoria/experiencia, asociada al movimiento corporal, acompañe la habilidad de captar e interpretar la realidad.

La discusión actual en torno a las herramientas ideales para la creación de un proyecto de arquitectura está inflamada por quienes defienden el dibujo tradicional frente al digital.

Javier Seguí entiende, desde sus tiempos en el Centro de Cálculo, que el ordenador no es un simple artilugio para crear, sino un instrumento fantástico para construir estructuras sintácticas y expresar el arte de una forma tan singular que es capaz de introducir nuevas formas de proyectar.

Si el arte está en la ejecución del "apunte" del ordenador, entonces el ordenador no significa artísticamente nada. Si está, aunque sólo sea en parte, en las estructuras que el ordenador puede revelar, entonces no se está haciendo buen uso ni de la herramienta ni de sus posibilidades. ${ }^{39}$

Dice Pallasmaa que las clases de imágenes más insípidas son las que se producen en ordenador al aplanar la imaginación a través de una manipulación visual pasiva. La imagen digital castra el contacto háptico haciendo de la obra una supresión de la sensibilidad. Se pierde la "visión periférica" que es la responsable por el entendimiento del mundo. Esa realidad que interfiere de manera decisiva en el sistema perceptivo y mental. ${ }^{40}$

Sin embargo, y en respuesta al grupo más tradicional y conservador, algunos autores declaran la "muerte a los prejuicios" y defienden el ordenador como herramienta fundamental para la ideación de la arquitectura. ${ }^{41} \mathrm{Si}$ es cierto lo que afirma Manuel J. Luque, que "la obra arquitectónica es fruto de la mente del arquitecto, pero no de sus manos, lo cual no es por obvio menos significativo" 42 resulta ridículo, en esta era tecnológica, considerar el lapicero o el papel de croquis únicos modos de acceder al mundo de las ideas. "Las nuevas tecnologías, además, facilitan que el resultado de esos garabatos -computerizados- se pueda

\footnotetext{
38 Javier Seguí, Dibujar, proyectar (XI) - Extrañeza (2) (Madrid: Instituto Juan Herrera de la Escuela de Arquitectura de Madrid, 2011), 29.

39 Javier Seguí, Arte e informática (Madrid: Fundación Citema, 1980).

40 Juhani Pallasmaa, Los ojos de la piel. Traducido por Moisés Puente. Barcelona: Editorial Gustavo Gil, 2006.

41 Antonio Álvaro Tordesillas y Begoña Cuesta Llaneza, "Muerte a los prejuicios," Ega

XII Congreso Internacional de Expresión Gráfica Arquitectónica (2008).

42 Tordesillas y Cuesta Llaneza, "Muerte a los prejuicios".
} 
construir. Con la mano habría que depurarlos para resolver cuántos problemas físicos constructivos." 43 La máquina trabaja ajena a los significados y a las emociones; la arquitectura deja de ser mera artesanía para transformarse en un producto digital. Deja a un lado la nostalgia histórica y observando el avance imparable de los adelantos tecnológicos -y, en particular, del software dedicado al dibujo arquitectónico-, cabe ver al arquitecto como un "programador de arquitectura", con lo cual el futuro de la profesión queda abierto, y plantea una Architecture without architects, como vaticina Bernard Rudofsky. ${ }^{44}$

No obstante, es tan erróneo cerrarse a las nuevas tecnologías como rechazar "la psicología del sentido común", que en la enseñanza se tilda de retrógrada e inculta". ${ }^{45}$

Resulta evidente que tanto la concepción como el desarrollo de un proyecto van unidos al desarrollo tecnológico y a las nuevas herramientas. El sector más vanguardista no duda en afirmar que deben aceptarse de una vez por todas las nuevas herramientas tecnológicas y desechar el manido croquis como arranque del proyecto, así como el "proyecto descendente de escalas en la definición, el diseño arquitectónico como líder indiscutible". ${ }^{46}$

Sin embargo, el croquis, entendido como esbozo arquitectóni$\mathrm{co}$, no trata de ser un grafismo para su posterior contemplación, aunque el mercado lo siga demandando como tal. El esbozo es, sobre todo, el germen de una "multi-interpretación" ideal, que entraña diversas soluciones: "La gráfica arquitectónica es un arte en que la forma expresiva sigue a su función implícita. El valor de su mensaje latente es mucho mayor de lo que habitualmente asumimos y es la gráfica del apunte lo que genera la visión espacial que será a su vez la arquitectura real." 47

A Javier Seguí, el "resultado" es lo que menos le importa en una primera fase. La metodología que propone empieza por un dibujo de concepción, que no tiene por objeto representar o calcular la idea, sino "sacarla fuera".

Desde una actitud de aprendizaje, lo que interesa no es tan-

43 Tordesillas y Cuesta Llaneza, "Muerte a los prejuicios", 45.

44 Martín, "El dibujo como medio didáctico atemporal".

45 Adolfo Morán Ortega y Fernando Morán Ortega. "La imaginación Arquitectónica y la "muerte del dibujo"." Ega XIII Congreso Internacional de Expresión Gráfica Arquitectónica (2010), 313

46 Atxu Amann y Eduardo Vivanco, "De qué va esto. El entendimiento del aprendizaje genérico y arquitectónico.," Ega XII Congreso Internacional de Expresión Gráfica Arquitectónica (2008): 52.

47 Antonio Millán Gómez, "Equivalencias: arquitectura, diagramas y el rechazo de lo icónico.," Ega XIII Congreso Inter. de Expresión Gráfica Arquitectónica (2008): 302. 
to la relación entre un edificio -entendido como realidad- y los distintos dibujos y planos que genera -entendidos como representación-, sino el tipo de dibujo imprescindible para intermediar con los mecanismos de la representación -mecanismos distintos a los convenidos para el dibujo imprescindible - para intermediar con los mecanismos de la representación, es decir, con las imágenes y sus relaciones. ${ }^{48}$

Para Seguí, no se puede hacer siempre lo mismo ni de la misma manera, pues se bloquea la imaginación, la creatividad y el pensamiento y por eso, Seguí

Desde pequeño el lápiz y el lápiz de color, más que otra cosa. Me gustan los aparatos que no rascan cuando dibujas, que dan placer. Ahora uso de todo". ${ }^{49}$

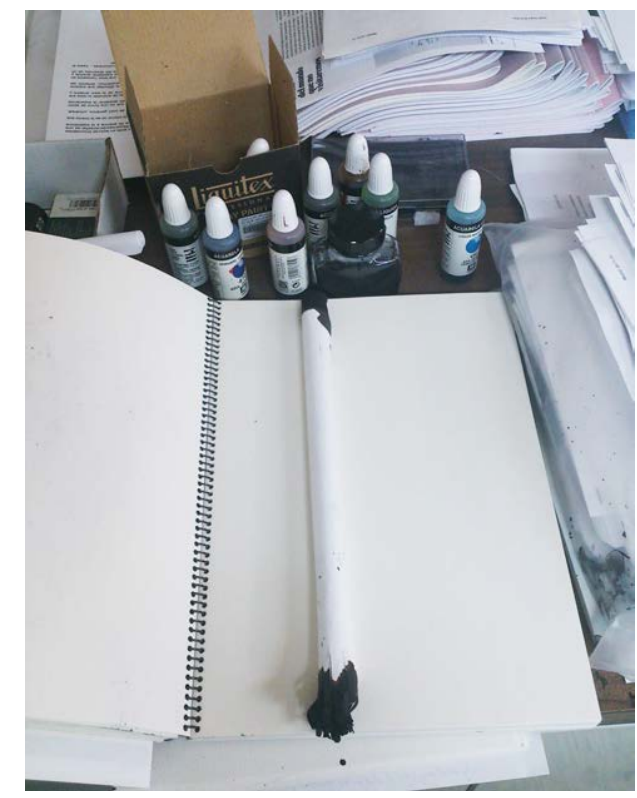

HERRAMIENTAS DE PINTURA, (2013). Instrumento de creación propia de Javier Seguí: un pincel elaborado a partir de una hoja de papel enrollada y con la punta cortada en tiras.

No le importan sólo las herramientas con las que dibuja, sino el dinamismo que transmiten al cuerpo. Desde luego no es lo mismo dibujar sentado en una silla, con el ordenador delante, que de pie, utilizando todo el cuerpo para impulsar el movimiento. "El ordenador ya no es 'una herramienta más', pero tampoco es 'la herramienta'." 50

\footnotetext{
48 Francisco Mederos Martín, "El dibujo como medio didáctico atemporal," Ega XIII Congreso Internacional de Expresión Gráfica Arquitectónica (2008): 297.

49 Javier Seguí, entrevistado por Maria Brito, 27 de agosto, 2015, Grabación.

50 Martín, "El dibujo como medio didáctico atemporal," 294.
} 
El cuerpo erguido... frente al papel, las piernas abiertas, los pies fijos para que el cuerpo se balance de adelante atrás. Con el cuerpo hacia delante se rotura el papel. Con el cuerpo hacia atrás se contempla el papel entero roturado. La mano derecha actúa soportada por el brazo/hombro, la izquierda contrabalancea ese movimiento trazador. La mano izquierda acaricia el cuerpo virtual que hay frente a los ojos, mientras, la mano derecha marca su movimiento reflejo impulsada por la tensión del cuerpo y el contra ritmo de la mano izquierda. Se completa así un modo de bailar acariciante, con los pies firmes, para que la sensación visual no cambie demasiado. Dibujar representando es un acariciar la virtualidad que la mirada estabiliza en el vacío, dejando la huella de ese acto en el soporte (el cuadro) que, sin otra posibilidad, se transforma en cuerpo ajeno, profanado, en mundo transitado, en reflejo exacerbado. En el dibujar no representativo, el referente desaparece y la mirada externa también. Queda una mirada latente frente al vacío envolvente. Mirada revestida, a la escucha de la danza interior. ${ }^{51}$

Sin embargo, si bien es cierto que es el movimiento el que determina el dibujo, la propia herramienta es la que condiciona el tipo de dibujo. Los dibujos de mancha, por ejemplo, sólo se pueden realizar con herramientas capaces de rellenar una gran superficie del soporte del que se trate. El cambio radical en la ultima década que se opera en el grafismo de Seguí, se debe al descubrimiento de los rotuladores con punta de hierro, con punta de pincel o con marcadores de fieltro, con punta extra grande que permiten dejar marcas intensas de manera instantánea, sin tener que repetir el trazado múltiples veces para conseguir ese mismo efecto de sombra.

Pese a que algunos autores afirman que un "buen dibujante no lo es por el instrumento que utilice para expresar sus ideas"52, disponer de un variado abanico de herramientas gráficas aumenta la posibilidad de poder grafiar de una manera más precisa lo que se desea expresar.

La relación entre "la arquitectura y las herramientas empleadas en su concepción" es idéntica a la que establece el pensamiento con el lenguaje.

\footnotetext{
51 Javier Seguí, Encuentros (XVIII) (Madrid: Instituto Juan Herrera de la Escuela de Arquitectura de Madrid, 2010), 29.

52 Carlos Montes Serrano, citado en Tordesillas y Llaneza, "Muerte a Los Prejuicios."
} 
タยアロロコロ

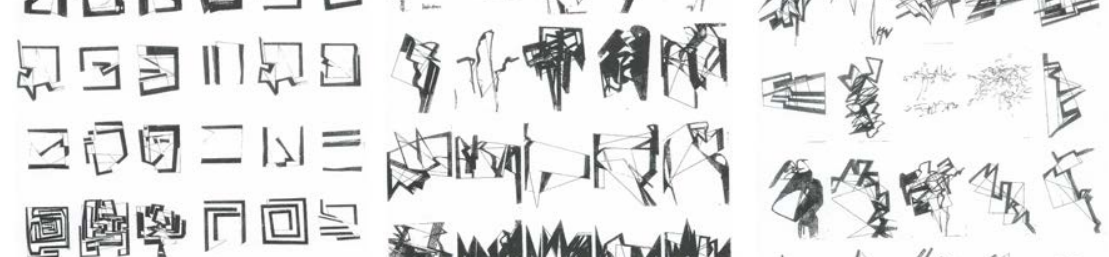

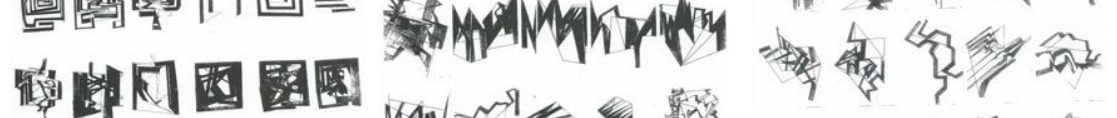
进虾相

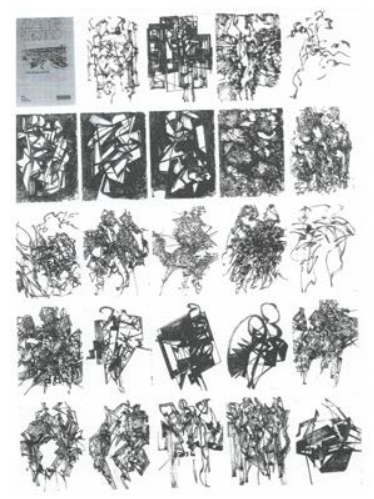

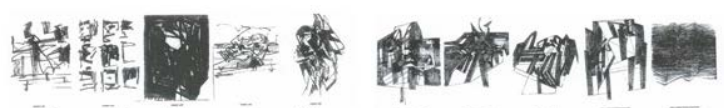

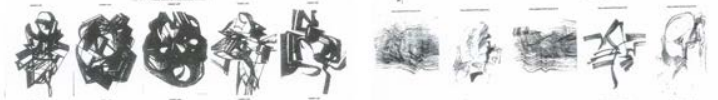

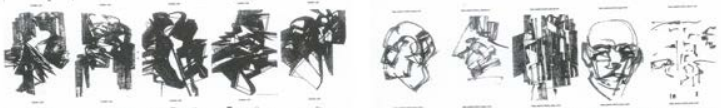

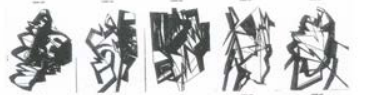

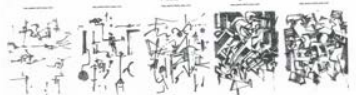

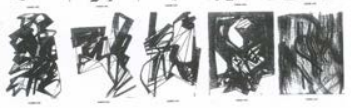

Wrin
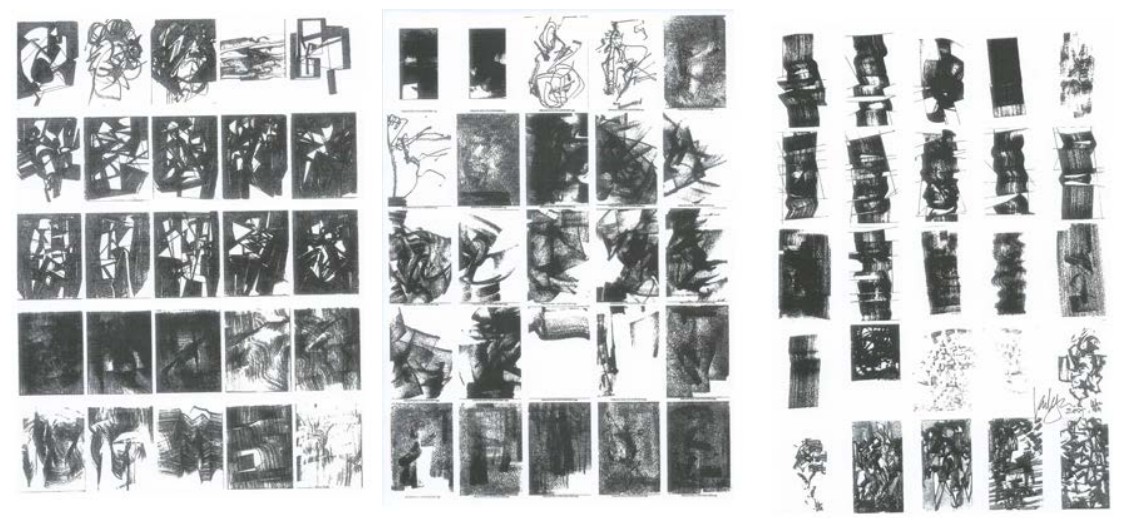

DIBUJOS ININTERRUMPIDO DIBUJAR, (2002-2015). Javier Seguí.

Además de los instrumentos que determinan la manera de dibujar en Seguí, existe otra variante que considera esencial en dichos cambios, relacionada con el contexto en que las produce. Hay dibujos realizados en soledad, mientras escucha música o a la vez que conversa con alguien, otras veces provienen de una reunión, o de cuando está en casa leyendo. 

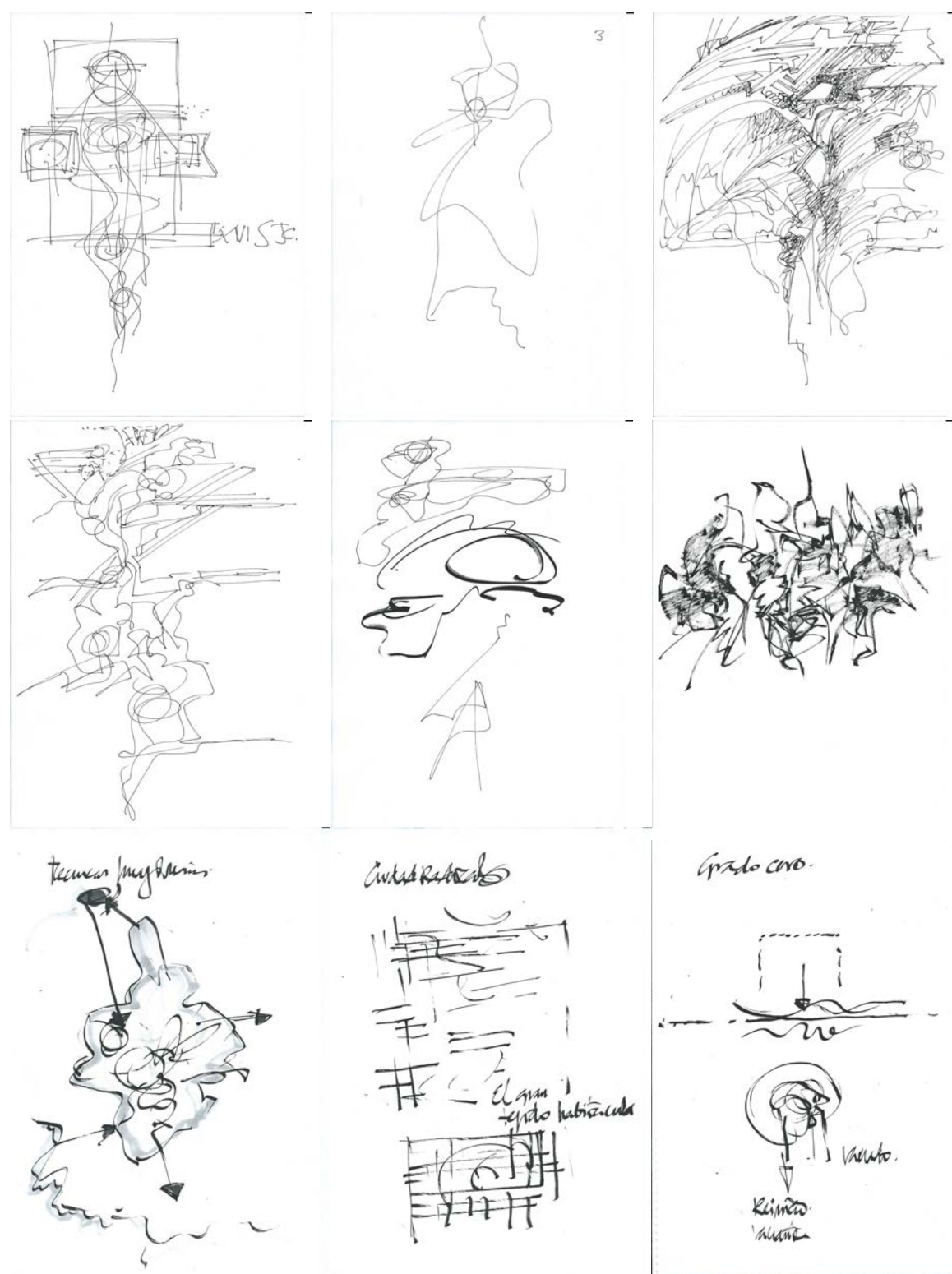

DIBUJOS, (2013-2015). Javier Seguí. Dibujos realizados por Javier Seguí durante las conversaciones mantenidas a lo largo de los dos últimos años. Mientras habla siempre tiene una hoja preparada para acompañar con la mano lo que la boca va dictando.

Una de las situaciones más habituales es ver cómo su mano y su pensamiento lo traicionan y lo llevan a representar a las personas que tiene delante cuando se encuentra reunido con alguien.

Aunque aparentemente se dibuja y representa lo que se ve, siempre se dibuja lo que se siente; hasta la representación mecanográfica de la realidad tiene una indudable conexión con el imaginario y las emociones. ${ }^{53}$ 

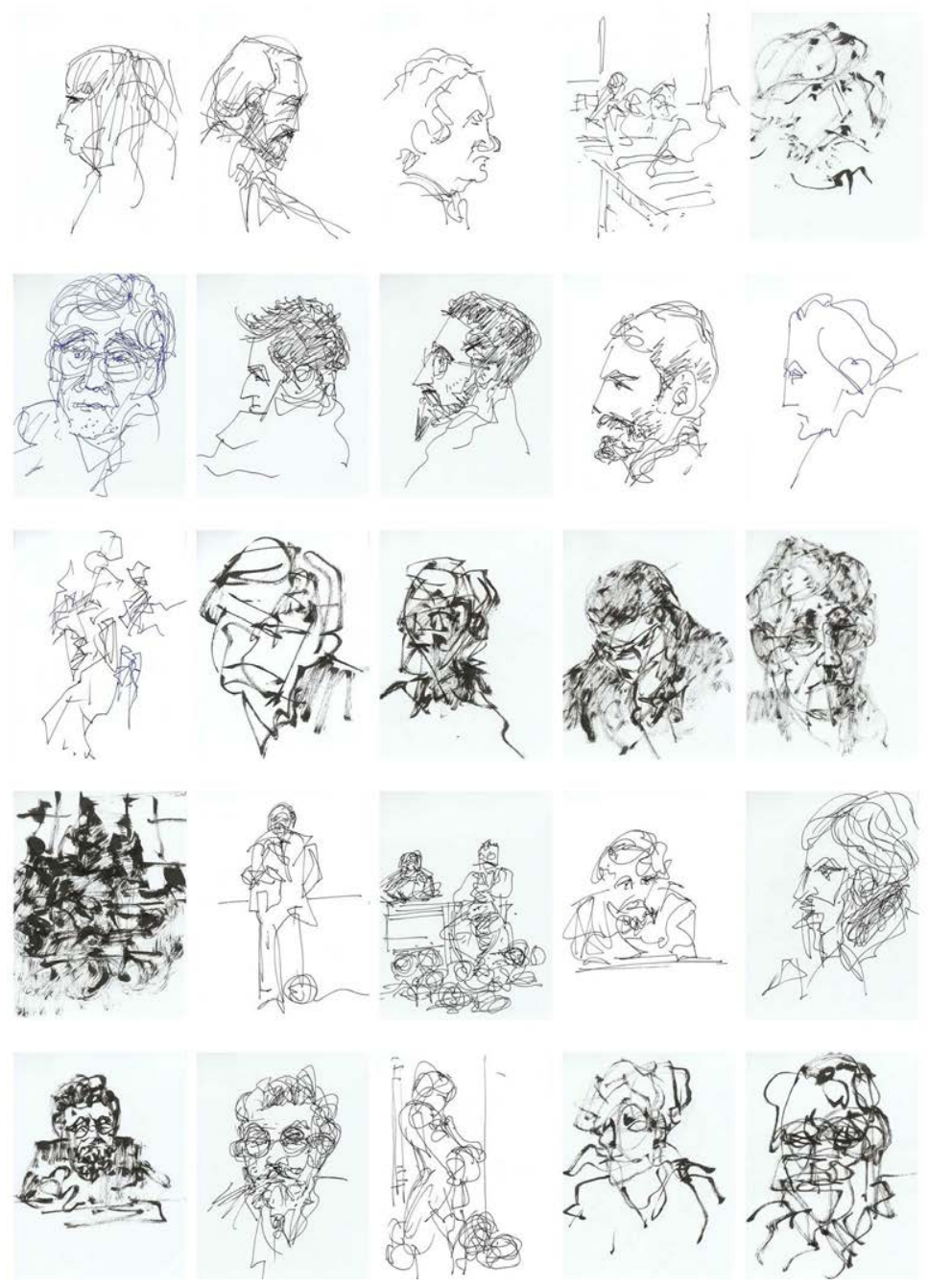

REUNIONES-CONFLICTOS, (2013). Javier Seguí. Dibujos realizados durante reuniones.

Seguí manifiesta que nunca ha sentido la necesidad de clasificar los dibujos de otra manera que no fuera la cronología, para mantenerlos ordenados de una manera neutra y descomprometida.

No podía entenderlos como objetos sueltos y quedé abrumado ante una obra insólita y única que nunca tuve el propósito pre-calculado de realizar. Mis dibujos, separados de sus cuadernos y moderadamente ampliados, formaban un ámbito indefinido que me englobaba como un mundo inexplorado realizado por alguien con mi misma sensibilidad movimental. Desde ese momento, no he podido por menos que acariciar la idea de estudiar mi producción para intentar encontrar en ella rasgos "normadores" repetidos y pautas diferenciales vinculables a las evocaciones que los dibujos despiertan. ${ }^{54}$

54 Seguí, "Ininterrumpido dibujar. Trazos, gestos, ademanes." 
Su última producción, ya muy alejada de su búsqueda inicial, alcanza ahora otro momento. Si en una primera fase el dibujo sirve para acercarse al proyecto, para ser parte de él, ahora, en la posiblemente última etapa del recorrido, Seguí desea vaciarse, llegar no a la esencia de dibujo, sino tal vez a la esencia de su propia existencia.

\subsubsection{ESCRIBIR}

Yo empecé a escribir sin rituales... algo me decía que escribir fijaba cosas (lo escrito), y rompía otras y era un reto de ordenación. ${ }^{55}$

No es erróneo decir que para Javier Seguí dibujar y escribir se funden y se confunden en su práctica incesante. Seguí escribe sobre dibujar y dibuja dejando huellas, como escritura abstracta, jeroglíficos habitables que se confunden tanto que algunas veces la propia escritura, como caligrafía, se transforma en dibujo.

Sus textos son la redacción de sus dibujos, y no deben ser interpretados por separado, pues se apoyan, se rectifican y se convalidan entre sí. Sus argumentos escritos confirman la intención de su producción gráfica, y de este modo el conjunto se torna una obra con un lenguaje universal.
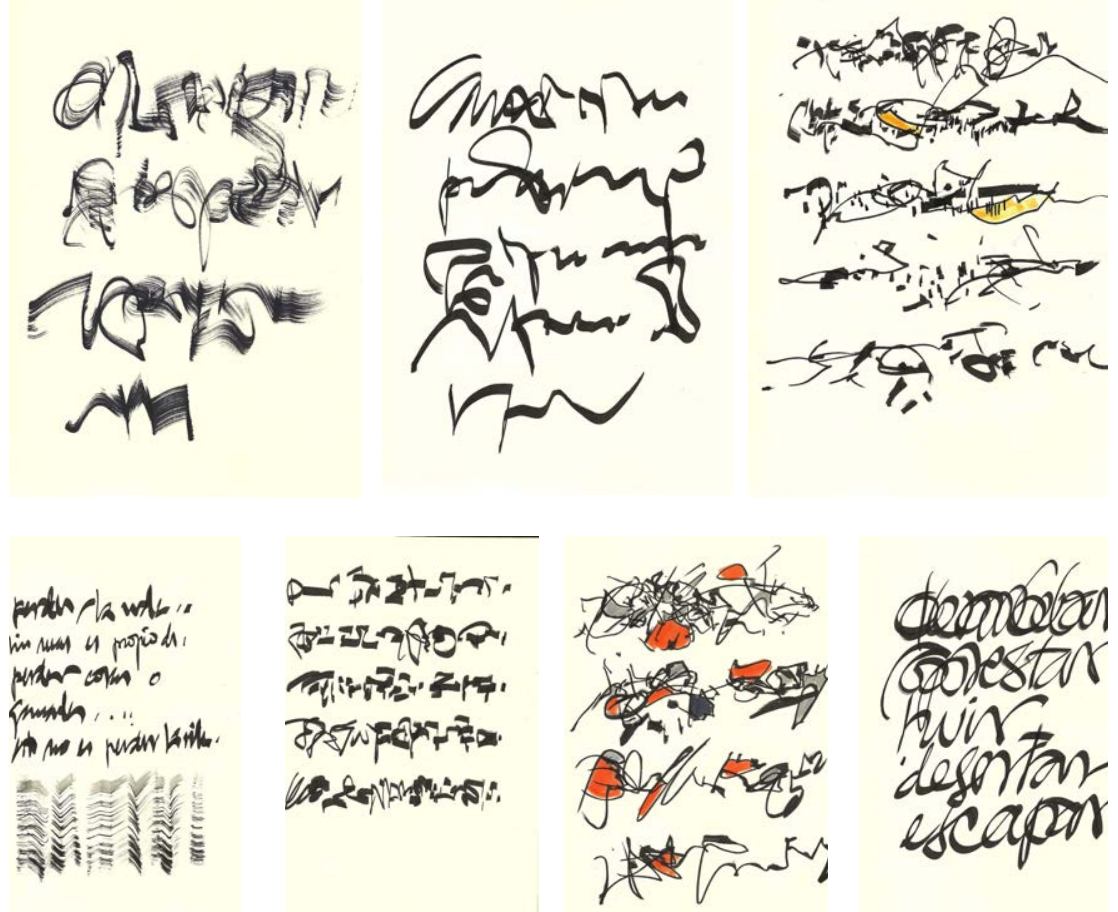

55 Seguí, Dibujar, proyectar (LVII) - Arte y muerte (2), 28. 


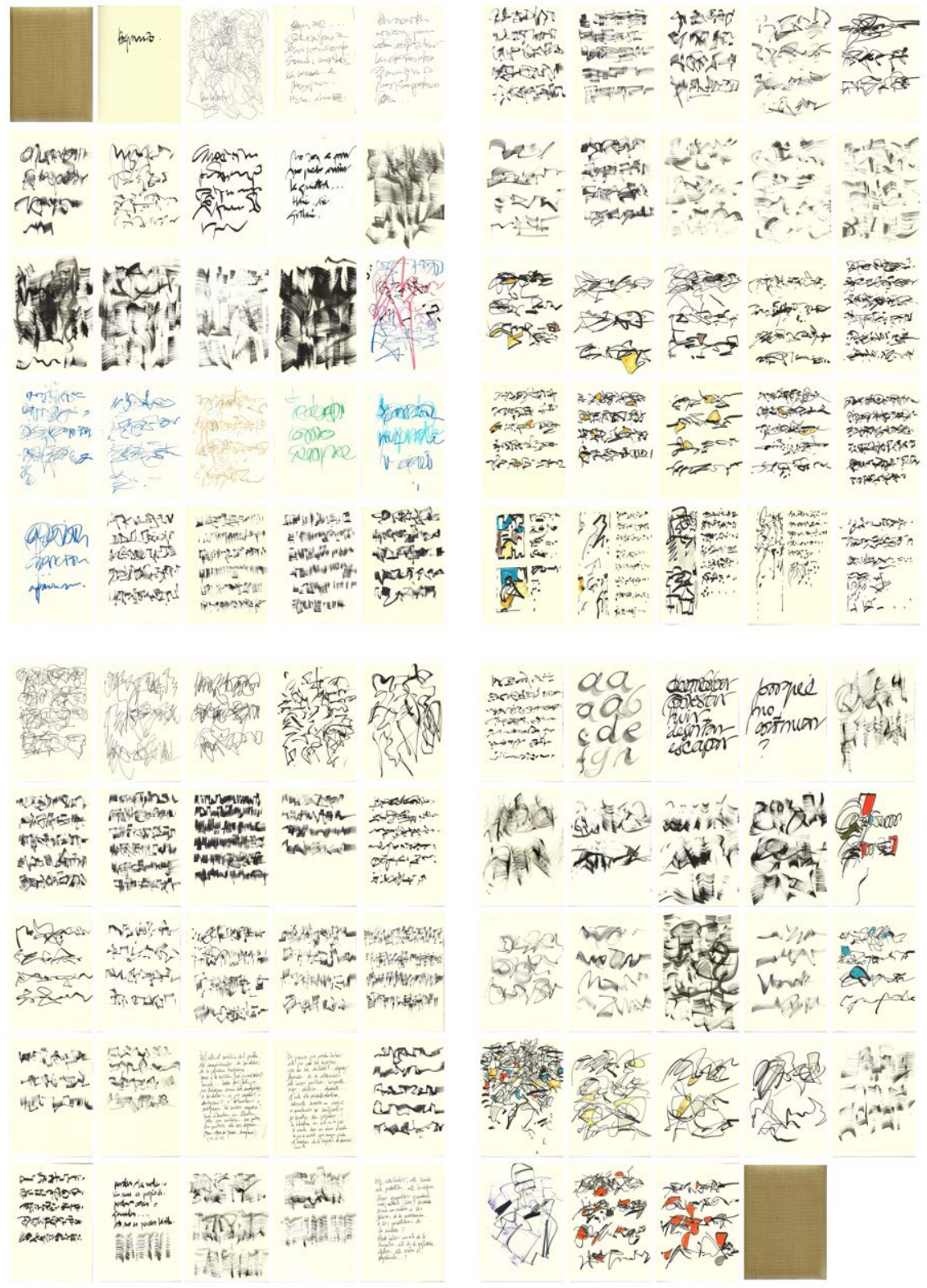

POEMARIO, (2013). Javier Seguí.

La escritura es entendida como otro modo de dejar huellas en que la mano rotura el soporte, lo araña y le deja un rastro de su pasaje en un lenguaje particular. ${ }^{56}$ Confiesa que "también sabía que las huellas de los movimientos gráficos a veces inventan la apariencia memorable de los acontecimientos visibles e invisibles, palpables e impalpables. Cuando atrapan los sonidos de la voz son escrituras". 57

\footnotetext{
56 Javier Seguí, "Anotaciones para un imaginario del dibujar," Ega 13 (2008): 75.

57 Seguí, "Ininterrumpido dibujar. Trazos, gestos, ademanes."
} 
Cuando se le pide la difícil tarea de elegir entre todos sus textos, uno que considere paradigmático, no tarda mucho en escoger una hoja, a doble cara, con dos textos escritos el mismo día, el 11 de octubre de 2010: en una cara, uno titulado "Dibujar, fantasear, formalizar", y en la otra: "Dibujar en la formación del arquitecto".

Dibujar, fantasear, formalizar.

Ser arquitecto es ser un soñador de ámbitos para la vida social (I. Sotelo).

Esos ámbitos se llaman edificios y son cáscaras técnicas preparadas para ser vistas desde fuera y ser usadas por dentro para ciertas actividades.

Los edificios se diferencian por su destino, desde el refugio/ descanso-reposición en la vivienda hasta la fiesta colectiva en la plaza...

El arquitecto tiene que conocer los usos sociales de los edificios (su tipología) y el modo técnico de su producción más económica.

El arquitecto hace proyectos, que son modelos reducidos de edificios que han de servir como materia de negociación y guía de ejecución, y esto lo hace manejando instrumentaciones intermediarias para plantear propuestas y para precisar... soluciones. La instrumentación indispensable ha sido el dibujar y el dibujo.

Dibujar como oficio de tanteo y dibujar preciso como herramienta de ejecución y control.

Al dibujar se le añadió desde siempre el maquetar, el hacer miniaturas de edificios y, ahora, se le añade la virtualización informática, que traduce en secuencias cinematográficas la experiencia de experimentar espacios.

Dibujar como atmósfera y medio de arquitecturar.

Hasta hace poco en las escuelas de arquitectura no se enseñaba a dibujar. A dibujar aprendía cada quien cómo podía. En las escuelas se hablaba de dibujos y los dibujos se suponían que eran reproducciones de cosas vistas, o en la realidad, o en la imaginación (lugar de recuerdos y de iluminaciones).

Hoy sabemos que ninguna cabeza puede contener en su interior una imagen clara de algo no experimentado, por lo que hoy sabemos que, cuando un dibujo no es una copia, es la resultante de un trabajo ímprobo de tanteos sucesivos, de trazos confusos que se van aclarando... 
Desde este punto de llegada podemos decir: el oficio de arquitecto es el de personas que transcriben en dibujos o maquetas la organización de lo que les rodea y son capaces de plantear novedades arbitrarias o razonables en el interior de un mundo minituarizado y plano donde son capaces de vivir la aventura de fantasear historias y procesos técnicos, es decir, mundos alternativos para la vida.

En la cultura occidental hay dos modos de estar frente al mundo: o viéndolo desde fuera y desde lejos, con visión casi divina (aérea), con pleno control geométrico de la forma y con una total desimplicación afectiva; o viéndolo desde dentro, de muy cerca, sin control y con total implicación afectiva.

Desde fuera y tocando se produce la geometría... la visión perspectiva, el control, vinculado con la música, con la armonía fija y zombi de un cosmos sin sus presas.

Desde dentro, y sintiendo con todo el cuerpo, se produce el fenómeno tenebrista barroco, la abstracción no representativa, la expresión informal, el contextualismo minimal, etc...

Desde fuera... es visión de control.

Desde dentro es sensación pática, afectiva, de estado...

Desde fuera es visual.

Desde dentro no es visual. Lo que nos rodea no lo podemos dibujar, ni fotografiar.

Los edificios no se ven.

La arquitectura tampoco...

Dibujar es acercarse al placer de trazar, a la experiencia de asombrarse trazando y al arranque de aprender a vivir los dibujos como lugares matrices, como ámbitos desarrollables, como escenarios para la vida.

Lo llamamos dibujar de concepción.

El arquitecto, luego, usa ese dibujar para romper los clichés de lo tipologizado.

El estudiante de arquitectura tiene que, aislado del mundo productivo, aprender a descubrir situaciones vitales radicales, desarrollarlas en narraciones diversas, y albergarlas en insólitos mundos figurales que han de poder, luego, ser construidos". ${ }^{58}$

\footnotetext{
58 Javier Seguí, "Dibujar, fantasear, formalizar," (Madrid: Instituto Juan Herrera de la Escuela de Arquitectura de Madrid, 2010).
} 
En este texto se aborda la misión del arquitecto de intermediar, precisar y tantear opciones que ajusten el edificio a su uso social y a su resolución más económica. Construir habitáculos, esqueletos tecnológicos para acoger la vida. Los edificios se erigen para ser vistos, pero sobre todo para ser vividos. Así pues su finalidad, privada o pública, determina su forma.

El dibujo sirve para sintetizar esos edificios en miniaturas, y el arquitecto, metafóricamente hablando, no es más que un "fabricante de miniaturas". El dibujo, visto desde fuera, revela la geometría del edificio, la aprehensión visual y en perspectiva/ sus formas. Pero es en su interior, desde su experiencia táctil y corpórea, donde se lleva a cabo su descubrimiento.

Dibujar es, por consiguiente, crear ambientes que serán vividos y experimentados. Y en opinión de Javier Seguí, estos espacios sensibles sólo se pueden conquistar si el arquitecto se vale del dibujo de concepción, que le permite tantearlos y asombrarse de su descubrimiento, "un dibujar -que no dibujo- como experiencia sensible." 59

La primera diferenciación entre dibujo de concepción y de presentación la establece Boudon, que distingue claramente el dibujo del proyectar del dibujo técnico. ${ }^{60}$ El dibujar de concepción es un dibujar del sentir y del ir en contra de las convenciones, el mismo que late en el barroco y que es una de las fuentes de inspiración del proceso de Seguí.

También el saber científico se ve restringido al naturalismo durante mucho tiempo, y sólo después de abandonar la noción racional de la materia es capaz de innovar los teoremas arcaicos. ${ }^{61}$ Esta dinámica artística del barroco, que pretende sustituir la idea objetiva por una idea sensible y separar la forma de la materia, es un claro reflejo de lo que sucede simultáneamente en el ámbito científico. Newton protagoniza uno de los abandonos de la realidad física más paradigmáticos para proyectar una innovadora configuración de las fuerzas estelares basada en el caos. "Aun conservando la representación por medio de las formas geométricas, se niega la estabilidad del sistema que aparece sometido al riesgo de una ruptura que se conjuraba en el perfecto orden geométrico anterior." 62

\footnotetext{
Martín, "El dibujo como medio didáctico atemporal", 297.

Seguí, "Para una poetica del dibujo", 69.

61 León Florido, "Forma y dibujo. Notas para una fundamentación filosófica del proyecto", 20.

62 León Florido, "Forma y dibujo. Notas para una fundamentación filosófica del proyecto", 17.
} 
Esa capacidad de desafiar las convenciones innovando y creando nuevas relaciones entre conceptos es el motivo por el cual Seguí insiste en que el estudiante de arquitectura no debe ser desviado de su proceso imaginativo. Sólo de este modo cuando ya sea arquitecto podrá ser lo suficientemente creativo para innovar e imponerse a los modelos restrictivos dictados por el mercado y la construcción.

Por este motivo, un estudiante de arquitectura debe ser capaz de sumergirse en ese mundo interior de ensoñación, alejado, sobre todo, de la codicia del mercado inmobiliario.

Dibujar en la formación del arquitecto.

Lo mío durante más de 45 años ha sido la práctica, la investigación y la docencia de la "no representación", del dibujar libre radicalizado (informal, planar, designativo) como ejercicio de entrada en el ámbito "realista-intelectual" del proyectar edificios. A este dibujar Soudon lo llamaba dibujar de "concepción" y algunos otros de "exploración" e incluso de "extrañamiento".

Siempre he entendido que la representación es un ejercicio-convención indispensable para tratar (descubrir, presentar, transferir) los edificios. Además creo saber que la duplicación de lo existente es una tarea imprescindible para fundar el universo simulable de lo virtual. Pero también he sabido siempre que la representación aleja, separa, mantiene a distancia $y$, por eso, es incapaz de consignar lo que nos envuelve, lo que nos contiene.

Además, atendiendo al hecho de dibujar, al marcar trazos en un soporte se llega a significar el dibujar como la roturación de un territorio, como la fundación de un lugar/ambiente en el que sentirse sumergido. Este carácter, quizás el más básico del dibujar, es el acceso al mundo fabuloso del proyectar edificios (diseñar), que requiere reducir el mundo hasta contenerlo en un papel y saber empequeñecerse hasta entrar en el soporte roturado y vivirlo como un interior sorprendente.

Para poder hacer esto el dibujo del dibujar tiene que dejar de ser representación para hacerse configuración habitable, lugar sin tamaño en donde jugar, tanteando encajar historias que han de caber en sus recovecos revestidos de significados espaciales.

El dibujar del proyectar es el dibujar del roturar, es el dibujar del sentir, de no mirar, el dibujar del arrastrar el vivir. Y el dibujo de proyectar es un dibujo plano, sin fondo, sin significado figural, sin evocación ilustrativa. Y a este dibujar se llega cuando se va contra la convención, contra el cliché representativo, cuando el dibujar se hace catástrofe, alejamiento, 
lucha contra la apariencia convencional.

Quizás este dibujar no se pueda reglamentar, pero sí se puede practicar. Ha sido el dibujar antirrepresentativo que palpita en el barroco (el barroco logra ámbitos donde poder alojarse, no sólo mirar) y, pasando por el expresionismo, cubismo, futurismo, etc., culmina en el expresionismo abstracto y en el arte conceptual.

Y es el dibujar de los arquitectos desde Vitruvio, pasando por Alberti, Leonardo, Rafael... dibujar en planta (desde arriba y desplazándose), en sección (de frente, pero desde dentro y en quietud) y en presencia... aunque el dibujo de alzados, según le Corbusier, no es un problema cuando la planta y la sección funcionan...

En la Escuela, la tarea de empezar a proyectar edificios se centra en la fantasía de alojar historias en dibujos en planta y sección y en hacer dibujos para contener historias (no para ilustrarlas).

Luego, el arquitecto en ejercicio tendrá que aceptar los tipos organizativos que le impone el mercado y los tipos constructivos que le impone la industria de la edificación, pero sólo será alguien si es capaz de modificarlos dentro de lo posible, y esto sólo lo podrá hacer rompiendo el cliché, teniendo el hábito de no representar, dejándose embargar por el designio catastrófico de dibujar sin perjuicios significativos. ${ }^{63}$

En este segundo texto, Javier Seguí contempla el convencional dibujo de representación, que trata de duplicar y reproducir lo existente con la finalidad de aprehenderlo, pero advierte que ese dibujo aleja y separa al creador de su obra. Un estudiante de arquitectura debe ser capaz de dibujar sin prejuicios, de dejarse llevar por el juego catastrófico, de ir en contra de lo convencional y de sumergirse en su propio interior. Sólo así podrá proyectar habitáculos de ensoñación y fabricar esas narraciones habitables que albergan no sólo cuerpos, sino comportamientos. Ya en 1922, en el Manifiesto Suprematista, se alerta de esta realidad:

Se afirma que las formas antiguas son importantes y que sólo unos necios no reconocerían el valor que tiene para el proletariado. (...) Reconocemos la grandeza de la arquitectura antigua. No negamos que fue grande para su época. Tampoco discutimos que el proletariado debe conocer la antigüedad clásica y adquirir un punto de vista correcto respecto a ella. Pero negamos decididamente que la antigüedad siga siendo adecuada para nosotros hoy. Toda nueva idea requiere una

63 Javier Seguí, "Dibujar en la formación del arquitecto," (Madrid: Instituto Juan Herrera de la Escuela de Arquitectura de Madrid, 2010). 
nueva forma adaptada a ella. Por ello nos negamos a aceptar que los templos antiguos, que sirvan tanto a los paganos como a los cristianos, también puedan ser utilizados hoy como "Casa de Cultura" para el proletariado, aun cuando, estos templos reciban los nombres de los dirigentes de la revolución y estén decorados con sus retratos. ${ }^{64}$

También a través de segundo texto, se deduce que su mayor preocupación de Seguí es la enseñanza, en particular la formación académica del arquitecto de cara a dibujar. En este texto Javier Seguí hace también una interesante referencia a su manera de entender el dibujo ortodoxo de arquitectura: planta, en presencia (alzado) y sección. Estos dibujos son, afirma, el resultado "de la situación relativa del dibujante respecto al soporte-marco donde actúa." ${ }^{65}$ En ambos casos se tratan de exploraciones gráficas de los ámbitos habitacionales. En planta, si es visto desde arriba, roturando un recinto apto para la vida humana. En presencia (alzado), con el soporte delante del dibujante, la materialización de lo que se eleva, un "tú a tú, de presencia a presencia". El dibujo en sección es la exploración del fluir, el sumergir, el transparentar lo que queda oculto. ${ }^{66} \mathrm{~A}$ este respecto menciona a hombres del Renacimiento (época de mayor aportación gráfica a la arquitectura) como Alberti o Marco Vitrubio. ${ }^{67}$

En cuanto a la pedagogía del dibujar, Seguí escribe de manera clara y concisa, con la madurez que le da su larga experiencia dedicada a la enseñanza del dibujo y a sus procesos proyectivos.

64 Pere Hereu Payet, Josep Maria Montaner, y Jordi Oliveras, Textos de arquitectura de la modernidad, trad. José Galán José Luis Gil Aristu, Ricardo Zayas y Joaquín Rodríguez (Madrid: Editorial Nerea, 1994), 220.

65 Seguí, "Anotaciones para un imaginario del dibujar," 81.

66 Seguí, "Anotaciones para un imaginario del dibujar," 81.

67 En su famoso tratado de Arquitectura, Vitrubio define tres términos gráficos fundamentales: "Ichnographia, Ortographia, Scenographia" (actualmente reconocidos como planta, alzado y perspectiva. Sobre estos tres procedimientos, Alberti expresa que al arquitecto sólo deben corresponder los primeros (alzado y planta) y que del tercer procedimiento (la perspectiva) deben ocuparse los pintores. Sin embargo, es con la "Scenographia", asociada principalmente a la perspectiva cónica, con la que la arquitectura establece por primera vez la "relación entre el interior del edificio y su exterior". El eterno conflicto entre las distintas interpretaciones y traducciones de la palabra de Vitrubio es el causante de que numerosos autores se enzarcen en una encendida discusión de perspectiva, modelo y sección: "La perspectiva era, para muchos, el deseado sistema capaz de expresar racionalmente el conjunto de una obra mediante el dibujo; el modelo respondía al mismo objeto que la interpretación anterior, pero siguiendo una tradición secular, utilizando la técnica de la escultura y, finalmente, la sección aparecía como la solución al evidente fracaso de los dos métodos anteriores para controlar un espacio arquitectónico complejo. En la perspectiva se era incapaz de medir, y en el modelo de definir y controlar eficazmente la Arquitectura." En, Lázaro de Velasco, citado por José $M^{a}$ Gentil Baldrich, "La interpretación de la "Scenografia" Vitrubiana o una disputa renascentista sobre el dibujo del proyecto," Ega1 (1993): 20-25. 
Analizando sus escritos a lo largo de estas décadas, se puede comprobar que, en los últimos años, tanto en los textos como en los dibujos todo se va fragmentando, deformando, en busca del puro placer, del puro desahogo. Citando a Barthes: "la escritura vibra, se fisura y pulveriza", de manera que su experiencia cinética del escribir se traduce en "experiencias de formas breves, haciendo de la fragmentación otra forma de extrañamiento". ${ }^{68}$

Los textos de Javier Seguí, que siempre acompañan sus dibujos, son, en este momento, refugios del inevitable curso de la vida.

Barthes sostiene que los escritores se dividen en dos grupos: los que "escriben algo" y los que simplemente "escriben". ${ }^{69}$ Con toda seguridad Javier Seguí pertenece a este segundo grupo. En una primera fase, sus textos están perfectamente estructurados, su construcción es bastante formal, ortodoxa, y su objetivo es claramente científico. Hoy se pueden ver centenares de hojas amontonadas en varias mesas de su despacho, como si fueran códigos listos para ser descifrados. Algunos de ellos no pretenden ser entendidos por completo, sino erigirse en una forma de aprender a morir extrañándose de uno mismo. Por eso, y a semejanza de lo que sucede con el dibujo, Seguí escribe con lo primero que encuentra a mano, pues no puede contener lo que necesita decir.

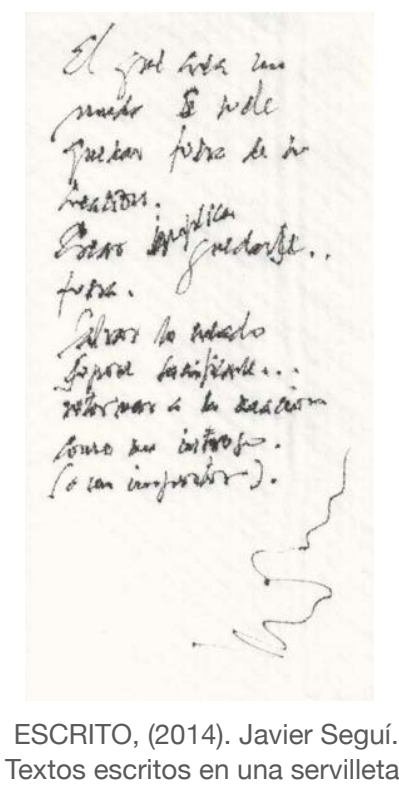

A semejanza de sus dibujos, también sus textos desean ser neutros, alejarse de las convenciones y ser un vehículo para el viaje

\footnotetext{
68 Seguí, Dibujar, proyectar (XI) - Extrañeza (2).

69 Seguí, Dibujar, proyectar (XI) - Extrañeza (2), 14.
} 
que el individuo realiza hacia su interior. Recientemente, y con tiempo para reclasificar su obra, Javier Seguí decide reordenar sus textos en dos grupos;

Al primero, con un contenido más cerrado y de estructura fija, lo Ilama Excerpta. Excerpta, del latín excerptus (elegido, entresacado), es una recopilación de sus escritos. Este nombre remite a Foucault, que denomina así a los textos que quedan a la espera de una utilización posterior.

01 Escritos sobre la enseñanza de la arquitectura:

- La formación del arquitecto.

- Alrededor de la enseñanza.

- Fichas pedagógicas 2009-2010.

- Planes.

- Arte.

- Poética.

02 Qué es arquitectura:

- Qué es arquitectura_TA_Talleres Temas de Arquitectura_1976.

03 Sin arquitectura:

- Desde fuera y desde dentro. Del todo a la parte.

- Miniaturas.

- Sin arquitectura.

04 Dibujar - Ser dibujo:

- Diseño.

- Especies.

- Ser dibujo.

- Escribir - Leer.

- Lenguaje, narración.

- Poéticas - Arte.

05 Ciudades radicales - Tejidos:

- El campamento.

- Imágenes (3D-City, Atlantis, C-Iceberg, Ciudad Cúbica, Ciudades Radicales, Vía Láctea).

06 Utopías - Fantasías - Mitos:

- Símbolos vinculados a la arquitectura.

07 Proyectar - Conjeturar futuros:

- El espacio del proyectar.

- Aprendizaje orientado a proyectos POL.

- Tipo - diagrama.

- Vivir - Arte.

- Investigación.

- Imaginación.

- Conjeturar futuros - Memoria.

- Poéticas.

08 En movimiento y en reposo:

- Movimiento y reposo.

- Hacer." 
Al ampliar las lecturas sobre estos temas surgen elementos cruzados, transversales, sin ámbito definido. Probablemente, y puesto que es psicólogo, siempre está buscando la forma de averiguar cómo incorpora el alma humana las cosas y las vuelca hacia el exterior. Dado el volumen que ocupan, Javier Seguí empieza a reunir en 2008 otro grupo de textos, totalmente abierto y en constante progresión.

09 Anotaciones:

- ANOTACIONES 1 - Doctorado - Máster.

- ANOTACIONES 2 - Acefalía.

- ANOTACIONES 3 - Teatro.

- ANOTACIONES 4 - Representación.

- ANOTACIONES 5 - Especies gráficas.

- Contra la representación.

- Índice textos.

- Informes.

10 Dibujar - Especies Gráficas.

11 Hacer arte - Proyectos - Proyectar.

12 Pedagogía:

- Cuaderno de apuntes.

13 Arquitectura - arquitectos.

14 Edades - Historia - Culpa.

15 Vitalidad - Muerte.

16 Cuerpo - Manos - Sentidos:

- Cerrar los ojos.

- Imágenes y vídeos.

17 Extrañeza.

18 Transitar - Atlas - Tejidos - Tarot-Juegos.

19 Lugares - Lugaridad - No lugares.

20 Memoria - Preguntas.

21 Muriendo - Arte y Muerte.

22 Ficción - Realidad - Narrar - Palabras Sentido.

23 Origen - Original - Emergencias - Sentido.

24 Arte colectivo - Arte plural:

- Germinaciones CBA.

25 Vacío - Vaciar - Discurrir - Palabras Sentido - Reverso.

26 Diagramas.

27 Concursos.

28 Delirio, delirar. Fantasear. Desear.

29 Edificar - Construir.

30 Imagen - Reparto de lo sensible.

31 Belleza.

32 CBA 2012-2013-2014.

33 Fantasías - Espacio interior - Ficción Mitos - Imaginario - Técnicas Imaginarias.

34 Taller Paisaje:

- Oscar Guevara.

35 Comunicación - Marketing - Mediación. 
36 Máster MPAA:

- Cotidiano - Marginalidad.

37 Viajar - Viajes.

38 Marginal - Fronteras.

39 Casa.

40 Nueva York.

41 Obras de referencia - Libros.

42 Doctorado - Tesis.

43 Misterio. Impulsos. Deseos. Narración.

44 Ciudades Utopías.

45 Arte - Ciencia.

46 Mundo - Envoltura - Lugar.

47 Máquina de entender el mundo.

48 Inquietudes.

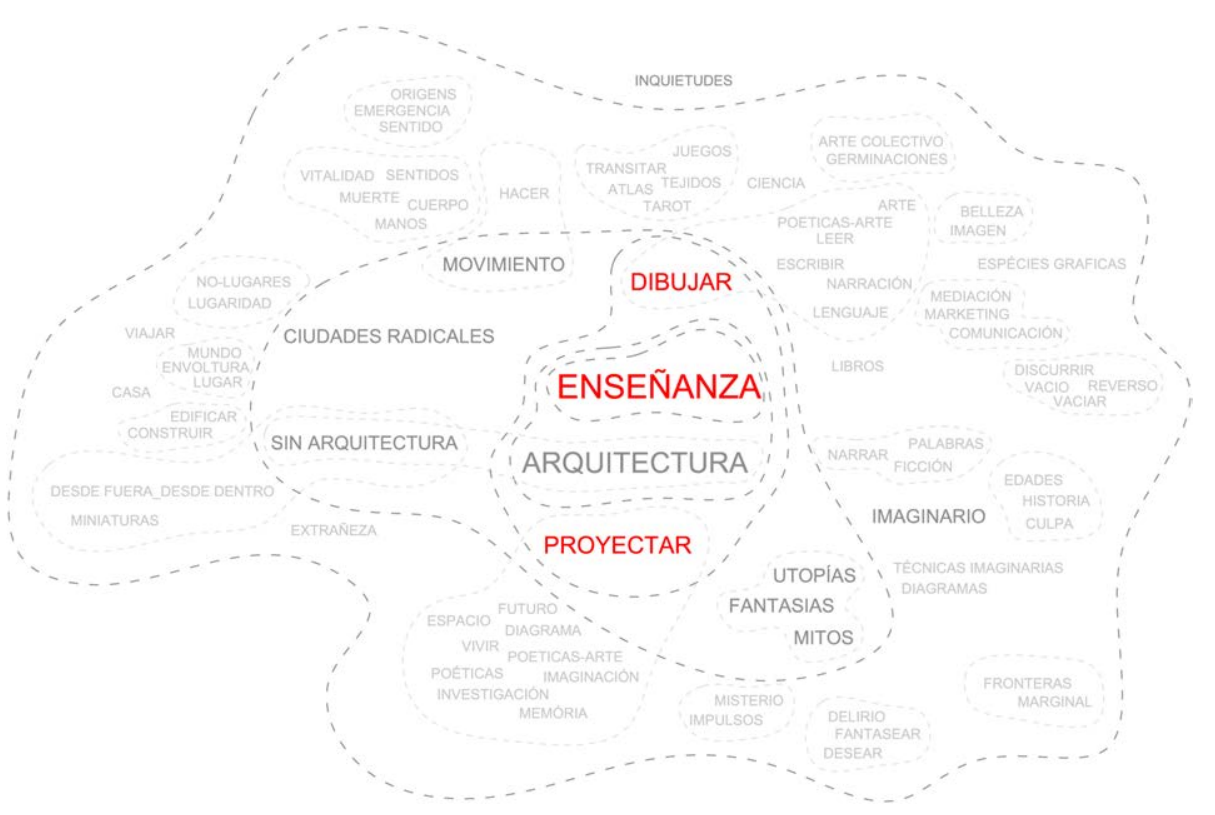

ATLAS TEMÁTICO DE LAS INQUIETUDES DE JAVIER SEGUÍ (2015). Diagrama elaborado a partir de los temas de sus textos. 
hacer

\section{2 enseñar aprender}

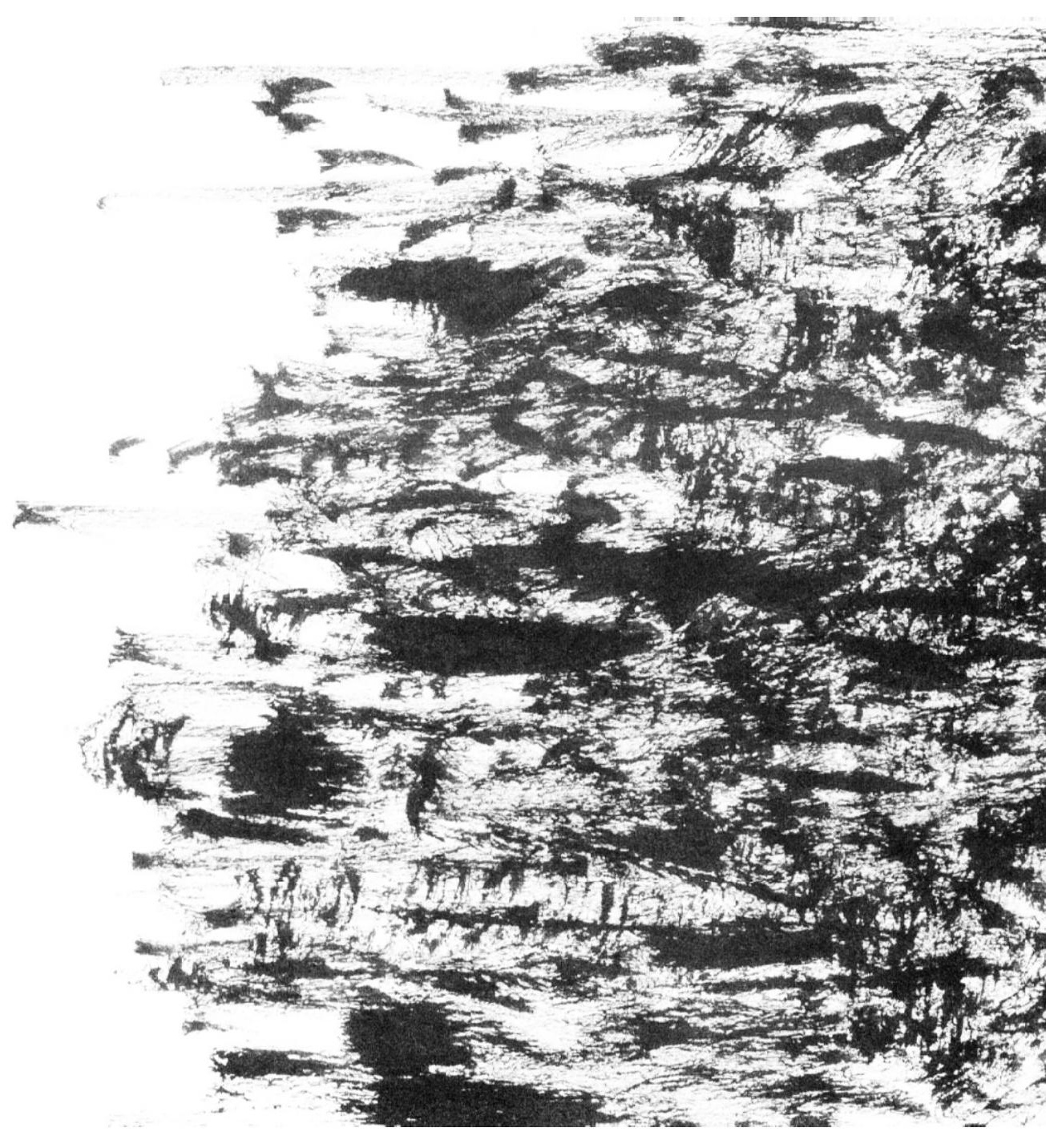



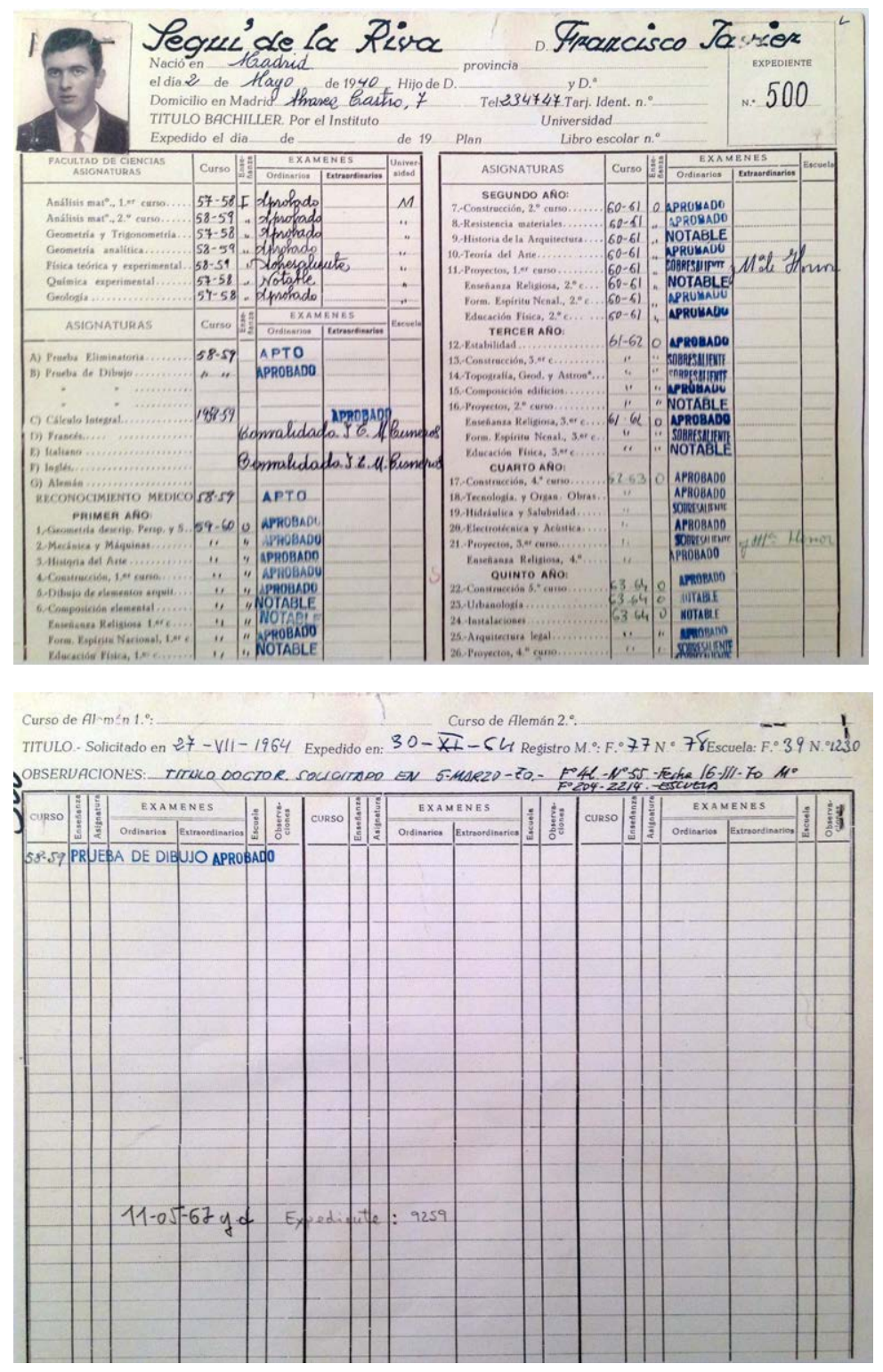

EXPEDIENTE ACADÉMICO. Javier Seguí. Expediente académico desde el año $1957 / 1958$ hasta el 1963/1964.

Francisco Javier Seguí de la Riva, nacido el 2 de mayo de 1940 en Madrid, ingresa en la Escuela Técnica Superior de Arquitectura de Madrid en 1959, después de dos años en la Facultad de Ciencias. Tras finalizar el bachillerato y el último curso -el denominado preuniversitario- en el Colegio Agustino de Madrid, se presenta a la prueba de Selectividad habiéndose preparado con la ayuda de un cura agustino amigo de su hermano. Durante ese año dedica las mañanas a leer lo que le va pasando un amigo suyo que estudia Filosofía y las tardes, a dibujar en la Escuela de Artes Aplicadas y Oficios de Madrid. 
En su vida académica, como se puede observar en su expediente, no hay clasificaciones negativas, ni suspensos. En el curso 1963/1964, el sueño de ser arquitecto, que abriga desde que tiene siete años, se hace realidad: termina la carrera con Matrícula de Honor: "Cuando terminé la carrera, en el año sesenta y cuatro, había sacado una nota extraordinaria. Era la mejor nota de todas las escuelas de arquitectura de España. Entonces, yo estaba destinado al éxito". ${ }^{70}$

Este comentario de Javier Seguí, que suena soberbio, se corresponde con una sensación de triunfo unida a un sentimiento de seguridad en el porvenir de un hombre que finaliza la carrera a los veinticuatro años, obteniendo un sobresaliente en el Proyecto Final de Carrera, y recibiendo el Premio Extraordinario y el Premio Aníbal Álvarez por sus logros académicos.

Como Proyecto Final de Carrera realiza una propuesta para unos estudios de cine. No recuerda con exactitud a todos los miembros del tribunal, pero afirma con rotundidad que forman parte al menos Luis Moya Blanco, director de la Escuela en ese momento, y los catedráticos Aníbal Álvarez y Javier Carvajal.
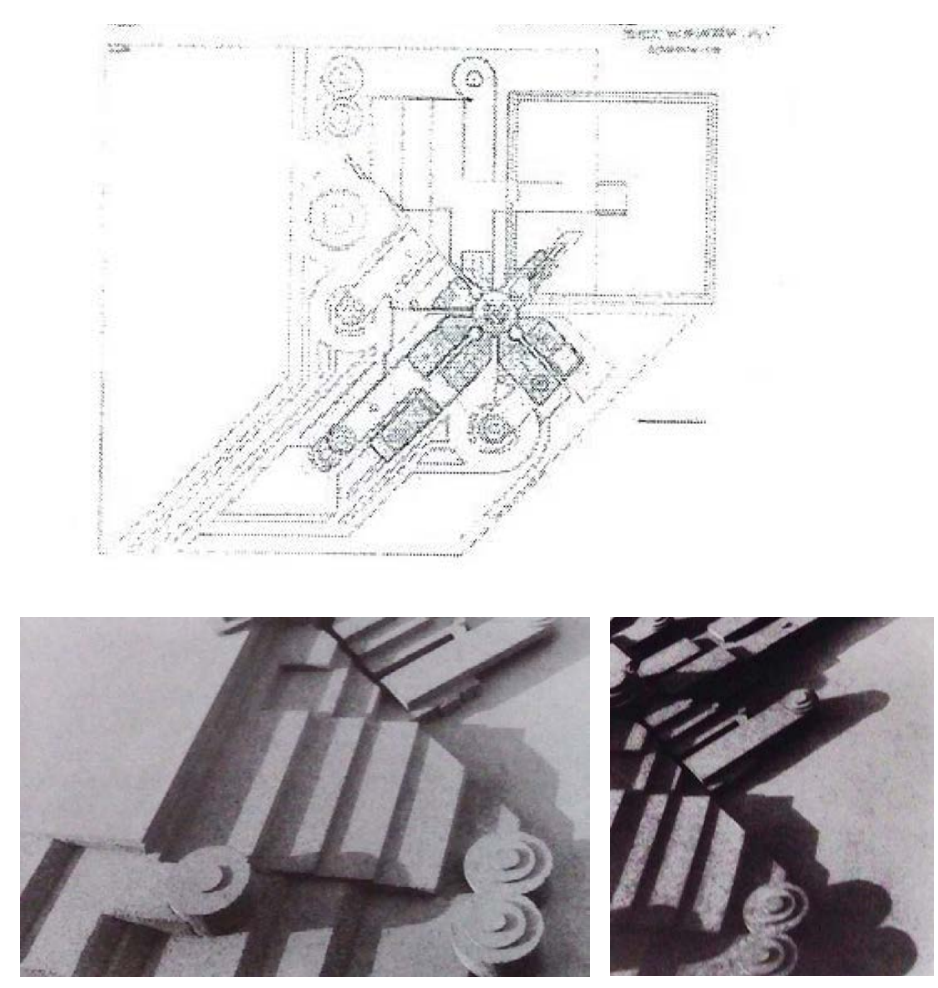

PROYECTO FIN DE CARRERA, (1964). Javier Seguí. Estudios de cine. 
Cuando termina la carrera, algo empieza a agitarse en el pensamiento de Javier Seguí. En la estructura pedagógica de los estudios que acaba de concluir, percibe que existe un gran vacío. En su opinión, "una de las cosas que faltan en las escuelas de arquitectura es la historia de las utopías. La formación del arquitecto está hecha en un mundo absolutamente ilusorio que no tiene nada que ver con nada, es absolutamente ficticio, cada uno fabrica sus delirios."71

En la formación del arquitecto también echa en falta, principalmente, una parte antropológica y humana que englobe al ser humano como individuo y su forma de relacionarse con los demás.

Como ve anteriormente, Javier Seguí, lector empedernido y consciente de la importancia que reviste esta herramienta en su formación, no puede entender, por ejemplo, que en la carrera, la lectura sea inexistente e incluso se vea con cierta antipatía por parte de todo el cuerpo docente. Por aquel entonces, algunos profesores, asegura, consideran que un buen arquitecto no leía ni la prensa. ${ }^{72}$

La idea de que la lectura no sea una parte fundamental en la formación de cualquier profesional le horroriza y lo deja atónito: "Ésa es una cosa que yo nunca pude entender. Aparte de diseñar edificios, hay que saber pensar, hay que leer, hay que saber quién es Platón."73

Este vacío formativo con el que se topa al finalizar la carrera lo impulsa, dos años después, en 1966, a estudiar Psicología en la Universidad Complutense de Madrid, licenciándose en 1968.

Durante esos dos años de formación adicional, recuerda la satisfacción de descubrir la psicología genética y diferencial de Jean Piaget y de su primer contacto con el mundo del Psicoanálisis de Sigmund Freud. Recuerda también a uno de sus profesores preferidos, José Luis Pinillos, y su introducción a la psicología experimental y a la teoría implícita de la personalidad.

Su trabajo de fin de diplomatura (1968) tiene por objeto un tema que siempre le ha interesado: la relación del dibujo con la psicología. Basa dicho trabajo en los estudios del test de Rorschach, el test de Wartegg y el test de apercepción temática de Murray; todos ellos tratan de evaluar la personalidad mediante una serie de láminas. 

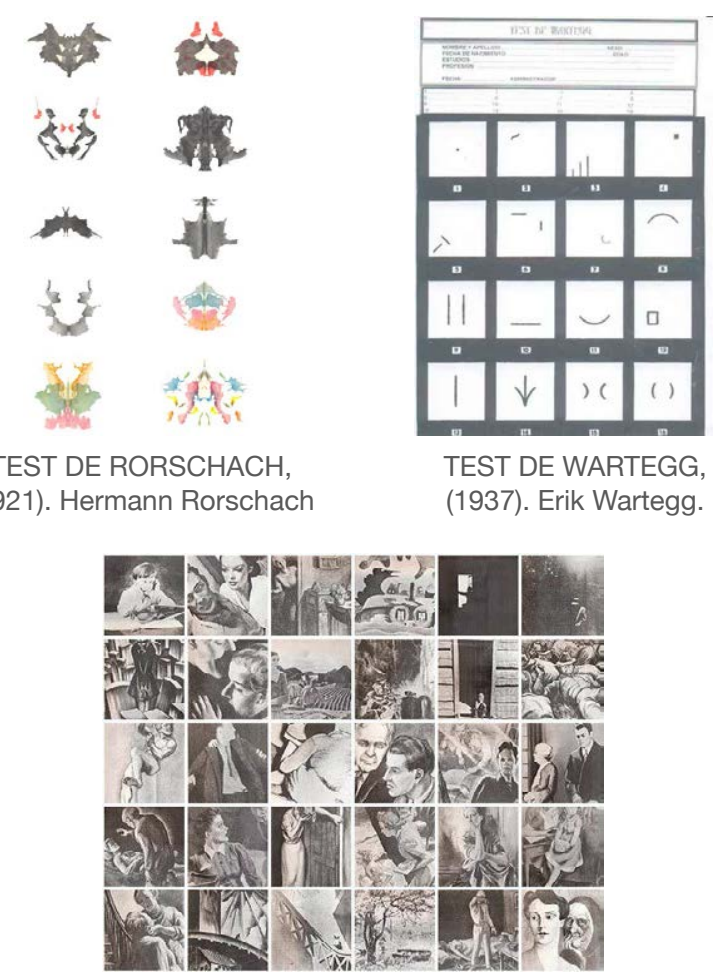

TEST DE APERCEPCIÓN,

(1938). Henry Murray..

El test de Rorschach o test proyectivo, desarrollado por el psiquiatra suizo Hermann Rorschach, pretende que el paciente encuentre en la subjetividad de las imágenes presentando asociaciones a otras imágenes visualizadas anteriormente. -Leonardo da Vinci habla de recibir inspiración de las imágenes proyectadas en piedras húmedas.

Estas imágenes difusas, indeterminadas son la manera de proyectar el mundo interior en el exterior. El dibujo deja de ser mero reflejo atento de la percepción para ser el reflejo de las emociones, de lo imprevisto, de las imágenes de las piedras húmedas y de los fantasmas. ${ }^{74}$

El test de Wartegg, ideado por el psicólogo alemán Erik Wartegg, requiere que el paciente complete una serie de cuadros a mano alzada a partir de estímulos recibidos por determinadas geometrías. El resultado de la composición, la intensidad del trazo y el uso del espacio determinan la valoración de su personalidad.

Por último, el Test de Apercepción Temática (TAT), creado por el psicólogo norteamericano Henry Murray, es asimismo una prue-

74 Pedro Burgaleta Mezo, "Imagen icónica, imagen fantasmática. Reflexiones para el desarrollo de una pedagogía poética," Ega XII Congreso Internacional de Expresión Gráfica Arquitectónica (2008). 
ba de evaluación psicológica en la que se pide al paciente que cuente una historia relacionada con las imágenes de las láminas que se le van enseñando. En ese sentido también el tarot puede ser considerado una especie de TAT por la analogía inconsciente de las imágenes proyectadas.

Estos tests psicológicos, basados en la interpretación de dibujos, fascinan a Seguí. Como dice, tienen mucho que ver con lo que hacen los surrealistas cuando intentan narrar una historia a partir de cosas comunes.

Progresivamente, en estos años, Seguí va acumulando nuevas teorías que años más tarde se convierten en un importante instrumento para el desarrollo de las innovaciones que desea proponer como docente en la cátedra de Dibujo; y, aunque nunca ejerce como psicólogo, su imaginario se ve influido por todas estas teorías.

Todo va según lo previsto. Su vida académica transcurre sin contratiempos hasta que, al término de la carrera, llega el momento de entrar en el mercado laboral, a mediados de los años sesenta. Ahora, como hombre adulto y casado desde 1964, es cuando Javier Seguí empieza a darse cuente de otra realidad que ni siquiera ha tomado en consideración: Con la primera oferta de empleo, en plena época del desarrollismo español, es consciente de la existencia de una serie de circunstancias despreciables, que muchas veces le resultan ofensivas.

\footnotetext{
Cuando terminé la carrera, en los años sesenta, con Franco en este maldito país si aceptabas un trabajo era siempre a cambio de algo. O devolvías honorarios o contribuías a engañar a alguien. La primera cosa que me ofrecieron fue una fábrica. En esa época del desarrollismo español, subvencionaban con $80 \%$ la construcción del edificio. Me propusieron que hiciera el edificio con el $30 \%$ más del presupuesto para poder cobrar bastante más. Otro caso alucinante fue cuando un tío me llamó porque era el número uno de mi promoción, y aunque sabía que le diría que no, me ofreció, estando yo en las islas Canarias, que fuera una vez a la semana a su despacho a firmar lo que tenían ahí. Me daban quinientas mil pelas al mes, que en aquella altura era una barbaridad. ${ }^{75}$
}

Las "quinientas mil pelas al mes" de entonces, que equivaldrían a lo mejor a unos cien mil euros actuales, son, en efecto, una cantidad de dinero difícilmente rechazable. Por esa época su imaginario, sin embargo, imbuido de lecturas, de viajes y de la convivencia con la familia socialista radical de su esposa, Ana 
Buenaventura, sumado a su estabilidad económica, lo mueve a rehusar empleos de ese tipo y a empezar a plantearse su futuro profesional.

Algo está cambiando en el interior de Seguí. El brillante alumno de arquitectura que desea ser arquitecto desde siempre empieza a dudar de lo que significa realmente su anhelada profesión. Los trabajos que le proponen son negocios corruptos, y la sensación de fracaso y frustración por no haber ganado nunca ninguno de los concursos a los que se presenta tiene un peso definitivo cuando toma la decisión de buscar otra forma de ganarse la vida: "Si hubiera ganado un concurso a los que me presenté, a lo mejor no estaría aquí. No sé lo que habría pasado. Pero no gané ningún concurso. Al mismo tiempo tuve ese rechazo tremendo con la vida real. Por eso la renuncia es un fracaso."76 Considera "muy noble" la disciplina de organizar el espacio, pero la corrupción que impera en el ramo de la construcción y lo que intuye subyace tras los concursos de arquitectura contribuyen de manera definitiva a despertar su desinterés por el oficio de arquitecto: "En ese sentido yo soy un fracasado. Al final no cumplo la expectativa de un colectivo de gente, incluso de mi padre, que estaba absolutamente convencido de que yo iba a hacer muchos proyectos". ${ }^{77}$

En un momento dado se da cuenta de que otra forma de ser arquitecto -y de ganarse el pan-, es participar en la formación de otros arquitectos. El mundo de la enseñanza entona ahora su canto de sirenas, que a su juicio es un proceso similar al de ejercer la arquitectura: organizar las pasiones de las personas.

En este contexto, el 11 de mayo de 1967 presenta la instancia para la obtención del título de doctor arquitecto ante la Junta General Calificadora del Ministerio de Educación. Para recibir el título, realiza un proyecto de urbanización, que, por desgracia, no se encuentra en su poder debido a un incendio que se declara en su estudio en 1985 .

Javier Seguí, doctor en Arquitectura, sigue persiguiendo sus retos profesionales en el mundo académico, y en 1972 decide presentarse por primera vez a la cátedra de Proyectos -anteriormente ocupa la cátedra de Composición, que tiene que abandonar por no contar con el diploma necesario para desempeñarla. Se enfrenta a arquitectos de la talla de Antonio Vázquez de Castro, que una década antes, entre 1956 y 1963, se hace cargo del proyecto del poblado de Caño Roto. Es consciente de que ser 
catedrático de Proyectos implica tener obra construida y, por tanto, de que compite tan sólo con su pensamiento y su fluidez ideológica. Así, basa su argumentación en que, más que la obra final, le interesa el proceso de dicha obra. De los tres concursantes iniciales quedan sólo dos, Antonio Vázquez de Castro, que al final se hace con la cátedra por un voto de diferencia y pasa un mes ingresado debido a una crisis de ansiedad provocada por la oposición; y él mismo.

Cuando comprende que no puede ganar la cátedra de Proyectos porque, efectivamente, no tiene obra construida, decidido a desempeñar una cátedra, dos años después, en 1974, se presenta a la oposición de Análisis de Formas Arquitectónicas. Él y otros ocho arquitectos se disputan dos plazas: una en Madrid y otra en Sevilla. Tres de los concursantes cuentan con obra hecha y cuatro son profesores de la materia; por su parte, él compite con su trayectoria académica y su experiencia como profesor adjunto de Composición y orientador del curso de Proyectos. Forman parte del tribunal el arquitecto Blanco Soler, los catedráticos de Dibujo, Lozoya y López Duran, el catedrático de Geometría, R. Aizpiri y el profesor de Composición, Manuel Borobio.

Tal como relata, la oposición cuenta con cinco pruebas de carácter teórico y práctico:

Las pruebas eran cinco y consistían en desarrollar tres temáticas y hacer y presentar un ejercicio práctico/gráfico. La primera prueba era el autobombo (autorretrato); la segunda era el desarrollo de un tema de una lista confeccionada por el tribunal; la tercera era el desarrollo de una lección; la cuarta era un ejercicio gráfico y la quinta, una exposición de lo averiguado en el ejercicio gráfico. ${ }^{78}$

En la primera prueba, enumera los concursos en los que ha participado y los grupos artísticos de vanguardia a los que pertenece. En la segunda, donde ha de desarrollar el tema de la textura, decide hablar de los vacíos. En la tercera, diserta sobre "el dibujar como proceso y el aprender a dibujar como ensayo tentativo de cambios del orden ejecutivo"79, discurso que alterna con dibujos realizados en un caballete. Antes de llegar al cuarto ejercicio, y evaluando las reacciones del jurado, empieza a intuir que ha ganado la oposición. En la cuarta prueba analiza la fachada del Museo del Prado, y en la quinta y última, donde debe exponer los

78 Javier Seguí, “La oposición a cátedra de análisis de formas arquitectónicas (1973) (13/97/2010)," (Madrid: Instituto Juan Herrera de la Escuela de Arquitectura de Madrid, 2010).

79 Seguí, "La oposición a cátedra de análisis de formas arquitectónicas (1973) (13/97/2010)." 